\title{
Effect of soil compactness on the growth and quality of carrot
}

\section{Liisa Pietola}

Agricultural Research Centre of Finland, Institute of Crop and Soil Science, Jokioinen, Finland Department of Applied Chemistry and Microbiology, University of Helsinki, Finland

\section{ACADEMIC DISSERTATION}

To be presented, with the permission of the Faculty of Agriculture and Forestry of the University of Helsinki, for public criticism in Auditorium XII, Aleksanterinkatu 5, Helsinki, on June 14th, 1995, at 12 noon. 


\section{Preface}

The experimental part of this study was mainly carried out at the Agricultural Research Centre of Finland in 1989-1992, the root analyses being completed in 1993 at Michigan State University, USA. The work was finalized in 1994 at the University of Helsinki, Section of Agricultural Chemistry and Physics of the Department of Applied Chemistry and Microbiology. I wish to thank Dr. Esko Poutiainen, Director General of the Research Centre and Dr. Paavo Elonen, Professor of Agricultural Chemistry and Physics at the Research Centre, for providing me the main financing and facilities for the experiments. I am very grateful to Dr. Alvin J. M. Smucker, Professor of Soil Biophysics at Michigan State University, East Lansing, for allowing me to join his laboratory for root analyses, and Dr. Antti Jaakkola, Professor of Agricultural Chemistry and Physics at the University of Helsinki, for his constructive criticism and support at the various stages of the work.

I wish to thank Docent Irma Voipio and Docent Erkki Aura for the valuable suggestions to the manuscript. I am grateful to the staff of the Agricultural Research Centre, especially to Mr. Tapio Salo, M.Sc., Mr. Risto Tanni, Mrs. Erja Äijälä and Mrs. Ritva Niemi at the Institute of Crop and Soil Science, for the skilful technical assistance in the experiments. I greatly appreciate the guidance and technical support of Mr. John. C. Ferguson, B.Sc. at Michigan State University. I also wish to thank the staff of the Department of Applied Chemistry and Microbiology at the University of Helsinki for the analysis of soil air composition and Dr. Inge Håkansson, Professor of the Department of Soil Sciences at the Swedish University of Agricultural Sciences, for allowing the determinations of soil reference bulk densities to be made in his department. The Figures (6-35) were drawn by Mr. Ari Törmä, M.Sc. and the English manuscript was revised by Mrs. Sevastiana Ruusamo, M.A., and edited by Mrs. Sari Torkko, M.Sc., which work I greatly appreciate. This investigation was financially supported by the Academy of Finland and the Tiura Foundation, which is gratefully acknowledged. I would also like to thank the board of the Agricultural Science in Finland for including this study in their journal. Finally, my warmest thanks are due to my family whose great support made it possible for me to complete this work. 


\section{Contents}

\section{Abstract}

1 Introduction

1.1 Importance of soil compactness to plant growth

Co soil compactness to plant growth ....

1.1.1 Consequences of excess soil compaction and loosening ......................... 145

1.1.2 Optimum soil compactness .................................................................. 146

1.2 Significance of soil properties to carrot rooting and yield quality .................... 148

1.3 Efficiency of root system .................................................................................. 148

1.4 Background and aim of the present study ........................................................ 149

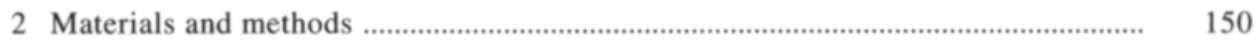

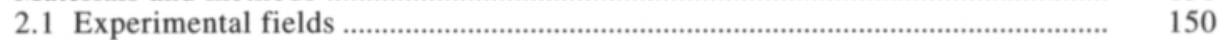

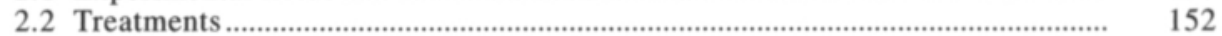

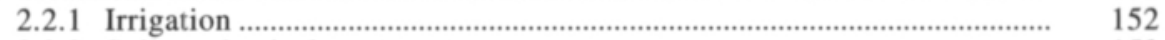

2.2.2 Soil mechanical treatments ................................................................ 152

Soil loosening .............................................................................. 152

Soil compaction ............................................................................ 152

2.3 Establishment and management of field experiments ..................................... 153

2.3.1 Fertilization and spring tillage ........................................................... 153

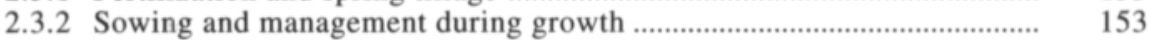

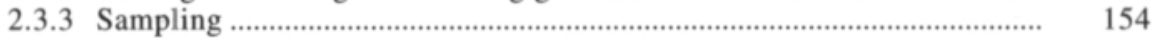

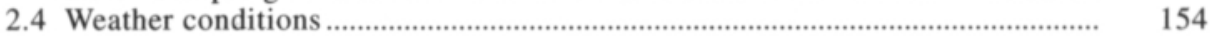

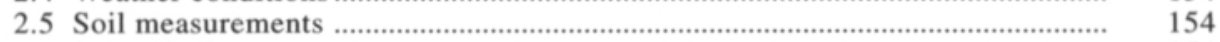

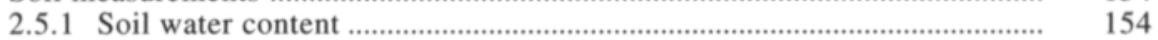

Electrical resistance .................................................................. 154

Sampling and drying .................................................................. 155

2.5.2 Soil dry bulk density ................................................................................ 155

Gravimetric analyses .................................................................. 155

Gamma ray transmission ........................................................... 155

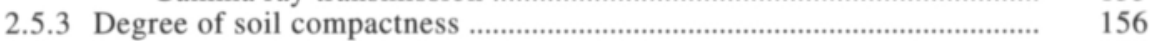

2.5.4 Soil penetrometer resistance ................................................................... 156

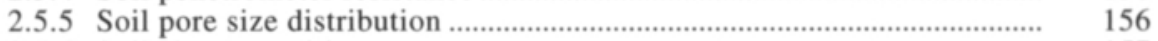

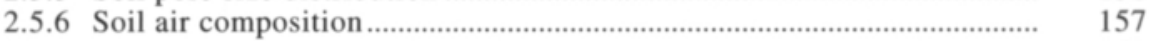

2.6 Plant measurements ........................................................................................ 157

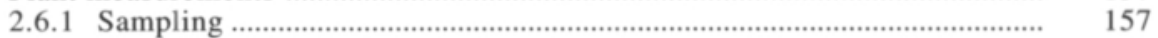

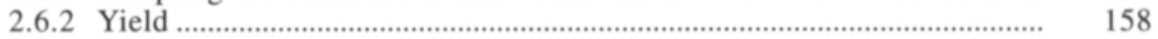

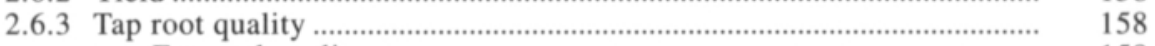

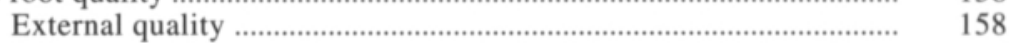

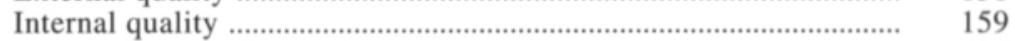

2.7 Studies on carrot fibrous root system ............................................................ 159

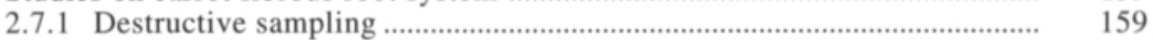

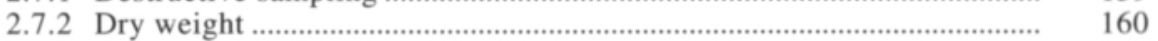

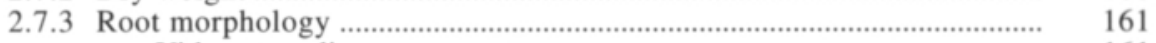

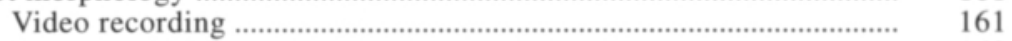

2.8 Statistical analysis......

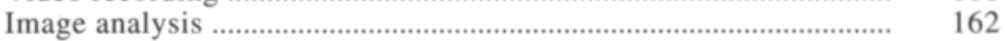

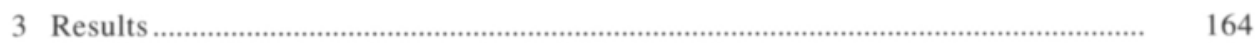

3.1 Effects of treatments on soil physical properties .............................................. 164

3.1 .1 Soil moisture .................................................................................... 164

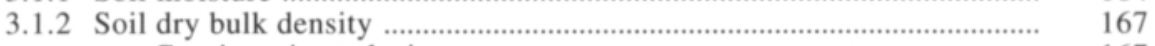

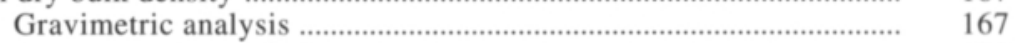

Gamma ray transmission ............................................................... 170

Gravimetric analysis vs. gamma ray transmission ........................ 171

3.1.3 Degree of surface soil compactness .................................................. 171 
3.1.4 Penetrometer resistance ........................................................................ 172

Relation to soil moisture and dry bulk density ................................ 175

3.1.5 Soil porosity and water retention capacity ................................................... 177

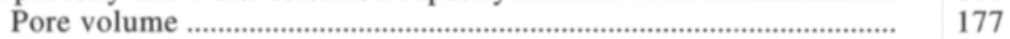

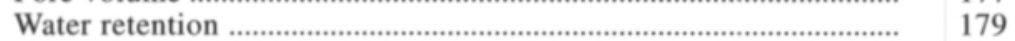

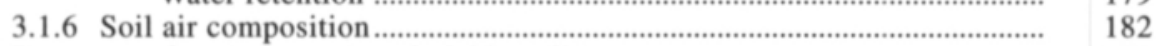

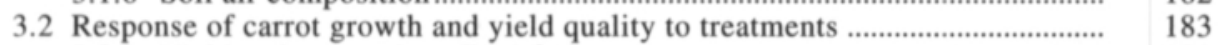

3.2.1 Yield and external quality of tap roots ....................................................... 183

Biomass accumulation ........................................................................ 183

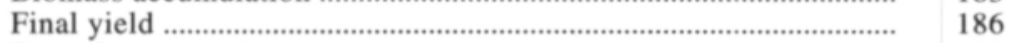

Root size ........................................................................................ 187

\begin{tabular}{l|l} 
Root splitting and branching ................................................................... 190 & 193
\end{tabular}

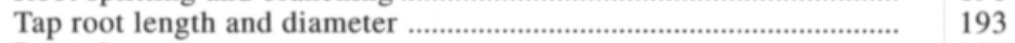

Root shape ...................................................................................... 193

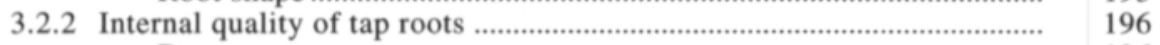

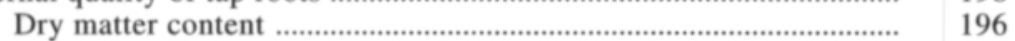

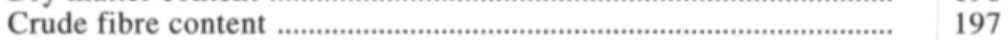

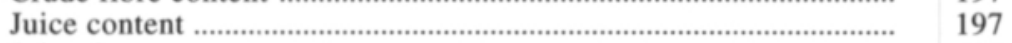

\begin{tabular}{l|l} 
Juice dry matter content ........................................................................ & 197
\end{tabular}

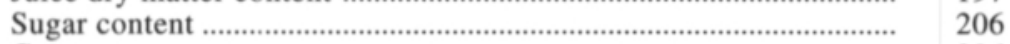

Carotene content .......................................................................... 206

Internal quality vs. root size ............................................................. 206

3.3 Response of whole-root system and shoot growth to differently treated soil

profiles in PVC cylinders ……........................................................................... 209

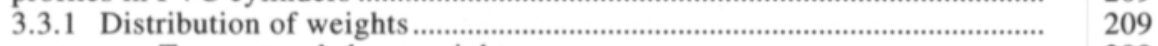

Tap root and shoot weight ............................................................. 209

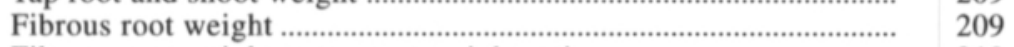

\begin{tabular}{l|l} 
Fibrous root weight to tap root weight ratio ........................................... 210 & 213
\end{tabular}

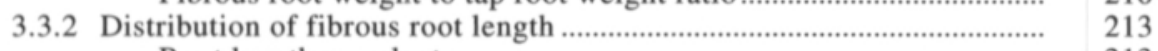

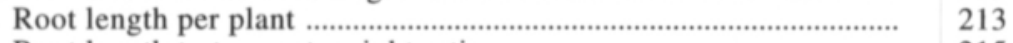

\begin{tabular}{l|l|l} 
Root length to tap root weight ratio ...................................................... & 215
\end{tabular}

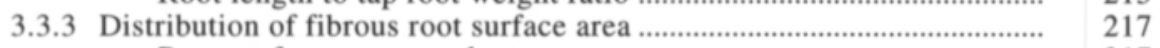

\begin{tabular}{l|l} 
Root surface area per plant .................................................................. & 217
\end{tabular}

\begin{tabular}{l|l} 
Root surface area to tap root weight ratio …………………………............ & 218
\end{tabular}

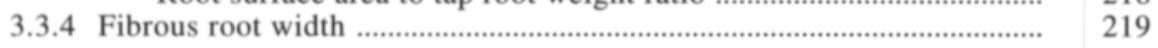

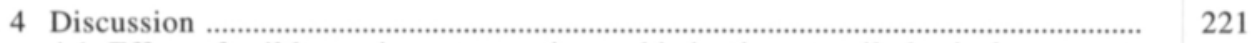

4.1 Effect of soil loosening, compaction and irrigation on soil physical

\begin{tabular}{|l|l} 
4.2 Effect of soil physical growth factors on carrot growth and yield quality ............ & 223
\end{tabular}

\begin{tabular}{l|l}
4.3 Role of fibrous root system in carrot response to soil compactness ...................... 226 & 226
\end{tabular}

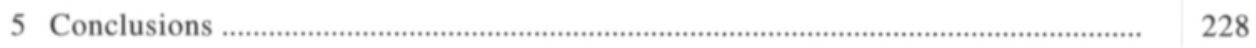

References ................................................................................................... 230

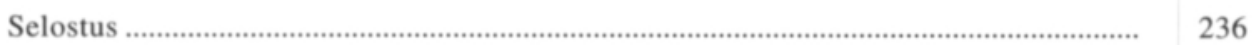

Appendixes 1-5 


\title{
AGRICULTURAL SCIENCE IN FINLAND
}

Pietola, L.: Effect of soil compactness on the growth and quality of carrot

\section{Effect of soil compactness on the growth and quality of carrot}

\author{
Liisa Pietola \\ Agricultural Research Centre of Finland, Institute of Crop and Soil Science, Jokioinen, Finland \\ Present address: Department of Applied Chemistry and Microbiology, P.O. Box 27, FIN-00014 \\ University of Helsinki, Finland
}

Field experiments were performed in Southern Finland on three soil types: fine sand (1989-1991), clay (1989) and mull (1990-1991). The following soil mechanical treatments were applied to autumn ploughed land: soil loosening by ridge preparation (ridge distance $45 \mathrm{~cm}$ ), rotary harrowing (to a depth of $20 \mathrm{~cm}$, clay $15 \mathrm{~cm}$ ), and soil compaction track by track by a tractor weighing $3 \mathrm{Mg}(1 \mathrm{or} 3$ passes, wheel width $33 \mathrm{~cm}$ ) before seed bed preparation. One plot was untreated. These treatments were set up in April (on clay in May) under moist soil conditions. Sprinkler irrigation (one application of $30 \mathrm{~mm}$ ) was applied to clay and fine sand when soil moisture in top soil had decreased to around $50 \%$ of plant-available water capacity. PVC cylinders $(\mathrm{r}=15 \mathrm{~cm}, \mathrm{~h}=60 \mathrm{~cm})$ were fixed in the experimental areas during the growing periods. At harvest, these cylinders were removed for specific analysis of tap and fibrous roots of carrot. Length and width of fibrous roots were quantified by image analysis in the USA.

The impacts of soil loosening and partial compaction were determined by measuring soil physical parameters to a depth of $25 \mathrm{~cm}$ in mineral soils, and to greater depths in organic soil. Dry bulk densities of the plough layers increased with increasing tractor passes by $8 \%, 10 \%$ and $13 \%$ for fine sand, mull and clay soils, respectively. The lowest dry soil bulk density in the plough layer was obtained by rotary harrowing to a depth of $20 \mathrm{~cm}$. Comparison of gamma ray transmission and gravimetric analysis indicated that dry soil bulk density was slightly lower when determined by gravimetric analysis. Increased soil bulk densities were reflected by increased water retention capacity (matric suction $\leq 10 \mathrm{kPa}$ ) and greater penetrometer resistance. Relatively similar increases in bulk density increased the penetrometer resistance much less in mull than in fine sand. In contrast, greater bulk densities in the mull soil affected soil air composition adversely by decreasing the $\mathrm{O}_{2}$ content to $10 \%$ when the subsoil had high wetness. In other soils, the lowest soil oxygen contents of $16-18 \%$ were recorded in early summer (compacted clay) and during periods of vigorous plant growth (fine sand) when soil water contents were high. Even though the highest degree of soil compactness (D) in a plough layer approached 93 (gravimetric) in all soils, only clay soil was compacted to a soil macroporosity below $10 \%$ (pore diameter $>30 \mu \mathrm{m}$ ).

Soil compaction promoted crop establishment and early growth as compared with loose soil beds. Optimum soil compactness for carrot yield $(D=82)$ was observed only in clay field where excess loosening or compaction affected yield quantity adversely at different stages of growth. During biomass accumulation, excessive penetrometer resistances limited tap root growth in compacted fine sand without irrigation. Water applications promoted shoot growth, but did not affect final shoot and tap root yield. Among the three soil types tested in this study, compaction of mull soil had the least effect on carrot growth and external quality. 
Vol. 4: 139-237.

This paper presents evidence that the internal quality of carrots is only slightly affected by changes in soil physical properties, while the adverse effects of soil compaction on carrot external quality (short, deformed and conical tap roots with greater maximum diameters) are clear. Even though compacted clay soil greatly limited the biomass accumulations in the tap root, which had a high crude fibre content, the carotene $(10 \mathrm{mg} / 100 \mathrm{~g}$ carrots) and sugar contents $(5 \%)$ reached acceptable levels. The lowest carotene contents ( $4 \mathrm{mg} / 100 \mathrm{~g}$ carrots) were observed in loose mull, following a cool late summer in 1990. The effect of irrigation on carotene content varied from one year to another.

High sugar and carotene contents appeared to respond to the high below-ground absorption surface. The fibrous root system of carrots, consisting of mostly very fine roots (diameter $0.15 \mathrm{~mm}$ ), had total lengths of $150 \mathrm{~m}$ in loose fine sand at a soil depth of $0-50 \mathrm{~cm}$ (rotary harrowed), $200 \mathrm{~m}$ and 300 $\mathrm{m}$ in fine sand and mull soils subjected to 3 passes by a tractor wheel. The maximum dry weight (60 $\mu \mathrm{g})$, length $(1.2 \mathrm{~cm})$ and surface area $\left(0.05 \mathrm{~cm}^{2}\right)$ of the fibrous root system per soil volume $\left(\mathrm{cm}^{3}\right)$ were observed in compacted or irrigated soil to a depth of $30 \mathrm{~cm}$, and also in relation to tap root dry weight. This suggests a capacity of carrot plant for high below-ground absorption potential and optimal biochemial maturation of tap root tissue even when surface soils are compacted. This is supported by higher leaf area, as the early shoot growth was promoted by partial soil compaction.

Soil compaction affected the soil physical properties and carrot external quality in agreement with previous studies. Carotene and sugar contents appeared to be unaffected or were slightly increased in riper and firmer carrots of compacted soils. This is consistent with the earlier information about the internal quality of carrot which is shown to be highly dependent on genetic factors and developmental stage of carrot. The present study emphasizes the surface area of carrot fibrous root system as a beneficial factor for maintaining high levels of carotene and sugar contents in tap roots after partial soil compaction.

Key words: tillage, traffic, soil physical properties, carotene, sugar, root length, root surface area, image analysis

\section{Introduction}

\section{I.I Importance of soil compactness to plant growth}

\section{I.I.I Consequences of excess soil compaction and loosening}

Poor aeration and high mechanical impedance are the major stress factors affecting the growth of most plants in compacted soil. Tractor wheel traffic, with axle loads of no more than $3 \mathrm{Mg}$ on wet clay soils, destroys the total macroporosity (pore diameter $>30 \mu \mathrm{m}$ ) to a portion below $10 \%$ of soil volume (Aura 1983) which is considered to be the critical limit for soil aeration maintaining plant growth (Glinski and Stepniewski 1985). This detrimental effect on soil porosity reflects in altered soil air composition (Eavis 1972, Simojoki et al. 1991) and in an oxygen diffusion rate below $30 \mu \mathrm{g} \mathrm{m}^{-2} \mathrm{~s}^{-1}$ which is too low for plant growth (Erickson 1982, Asady et al. 1985). In highly compacted soils the root to soil contact may be so intense that aeration of the root tissue is completely dependent on the internal air channels in the root (Veen et al. 1992). Further, as soil compaction has an adverse effect on saturated water retention capacity and infiltration (Blake et al. 1976, Reicosky et al. 1981, Ankeny et al. 1990), poor aeration of compact and flooded soil inhibits root growth and nutrient uptake (Grath and Håkansson 1992). Under localized anoxia, compensatory root growth causes inefficient utilization of carbon and additional uptake of water and nutrients (Schumacher and Smucker 1984, 1987). 


\section{AGRICULTURAL SCIENCE IN FINLAND}

Pietola, L.: Effect of soil compactness on the growth and quality of carrot

Mechanical impedance is another component of soil compaction often implicated in poor growth. Pohjanheimo and Heinonen (1960) reported that the hardening and drying out of clay loam soil may entirely inhibit the penetration of barley roots into the subsoil. Soil strength on some roots is reflected also as reduced growth rate of other plant parts (Massle and Passioura 1987). In the absence of continuous large pores, soil resists the local deformation caused by roots, and there is a definite upper limit to a pressure near $1 \mathrm{MPa}$ in the axial direction and 0.5$0.9 \mathrm{MPa}$ in the radial direction which can be exerted by roots of a given species (Pfeffer 1893, ref. Gill and Bolt 1955, Misra et al. 1986). Radial expansion of a root behind the tip causes a lowering of external mechanical impedance ahead of the elongating root (Abdalla et al. 1969, Richards and Greacen 1986).

Mechanical impedance measured by penetrometers should be regarded as comparative, not absolute values. The static and additive frictional components of penetrometer probe results in greater soil resistance values than for a root (Farrell and Greacen 1966, Whiteley et al. 1981). According to Materechera et al. (1991), the soil penetrometer resistance of $4.2 \mathrm{MPa}$ corresponds to an external mechanical resistance on the roots of approximately $1.14 \mathrm{MPa}$.

The pressure at the root apex cannot, however, be the only determining factor regulating the root elongation rate, as a clear relationship has been observed between the penetrometer resistance in the top layer and root growth rate in the subsequent loose layer (Bengough and Young 1993). The restricted root growth with morphological deformities, such as diameter growth and compensatory growth of laterals, is a general symptom of too high soil strength under field conditions (Wiklert 1960, Voorhees et al. 1975). Mechanically impeded roots, in turn, exhibit an increased respiration rate per unit root length (Schumacher and Smucker 1981, Atwell 1990a, b).

Poor water supply and small root to soil contact area of loose soil can also contribute to poor growth. Soil needs some compaction, i.e. soil compression (Smucker and Erickson 1989), to be the most productive (Håkansson 1966, Johnson et al. 1990). This has been proved particularly during drought periods, due to lower volumetric water content (Boone et al. 1978, Domzal and Hodara 1992) and, thus, a weaker unsaturated hydraulic conductivity in loosely packed fine textured soils than under slightly compacted conditions (Kemper et al. 1971, Voorhees et al. 1979, Mehta et al. 1994). On the other hand, soil compaction reduces water conductivity of coarse textured soils at matric potentials between 0 and $-60 \mathrm{kPa}$ (Lipiec and Tarkiewicz 1984). According to Agrawal (1991), this improves the productivity of sandy soils with too high water infiltration by reducing losses of water and nutrients. Compaction of sand has been reported to increase yields by as much as $30-50 \%$.

The poor contact area between root and loosely packed soils has been discussed recently: Kooistra et al. (1992) measured by a thinsection tehnique average root to soil contacts of 60,72 and $87 \%$ for sandy loam of a porosity of 60,51 and $44 \%(v / v)$, respectively. They also proved that water absorption and nitrate uptake per unit maize root length decreased with loosening soil and with decreasing root to soil contact (Veen et al. 1992). Similarly, Huang (1990) demonstrated that the greater root to soil contact at the high bulk density of water deficit plants increased water absorption per unit of roots growing in clay soil. These results are well in agreement with the earlier measurements of Lipiec et al. $(1988,1992)$ which indicated a faster and higher water absorption by a plant growing in compacted soil than in loose media.

\section{I.I.2 Optimum soil compactness}

Measurements for soil compactness include analysis of soil dry bulk density and soil porosity. Different sizes of penetrometers have been used to indicate soil strength of dense layers (Bengough and Mullins 1990) or profile characteristics after various tillage operations and com- 
Vol. 4: 139-237.

paction (Carter 1988, Akker et al. 1994). A measurement for soil property which is related to the variation in continuous pore size distribution, like saturated water conductivity, should be included in the analysis of soil compactness as well (Hartge 1992). To be able to compare the results of soil compactness between different soil types, soil compactness has been determined also as a relative value by means of the reference state. Håkansson (1990) specifies the relative soil compactness as a "degree of soil compactness" (D) which is given by the formula:

$$
\mathrm{D}=100\left(\rho_{\mathrm{d}} / \rho_{\mathrm{d}, \mathrm{p}}\right)
$$

where $\rho_{\mathrm{d}}$ is the dry bulk density of a soil $\left(\mathrm{g} \mathrm{cm}^{-3}\right)$ and $\rho_{\mathrm{d}, \mathrm{p}}$ the dry bulk density of the same soil $\left(\mathrm{g} \mathrm{cm}^{-3}\right)$ after excessively compacted to the reference state by an unaxial pressure of $200 \mathrm{kPa}$ until drainage and compaction ceases (after 1 week). Initial soil water contents are near field capacity (matric suction $\approx 10 \mathrm{kPa}$ ).

Optimum soil compactness is reached by avoiding excessive soil loosening and compaction. According to field experiments in Sweden during the last three decades, barley yield is highest at $\mathrm{D}$ around 87 in all mineral soil types. This compactness is achieved with one pass of a tractor wheel on moist ploughed land during spring tillage. The finding is well in agreement with results from Norway (Riley 1988) and Poland (Lipiec et al. 1991).

The variation in seasonal precipitation explains well the differences between yields attained at the optimum and non-optimum states of soil compactness (Lipiec et al. 1992). The disadvantages of soil compaction are most prominent after excessive rains which cause oxygen stress. Similarly, lower optimum soil densities are needed during rainy seasons because there is a smaller need to retain all of the water (McKyes et al. 1979, Medvedev 1992). Thus, according to Håkansson (1992), the relation between plant growth and soil compactness is understandable only if soil moisture status has been measured along the growing period. He outlined the critical values of soil air content, penetrometer re-

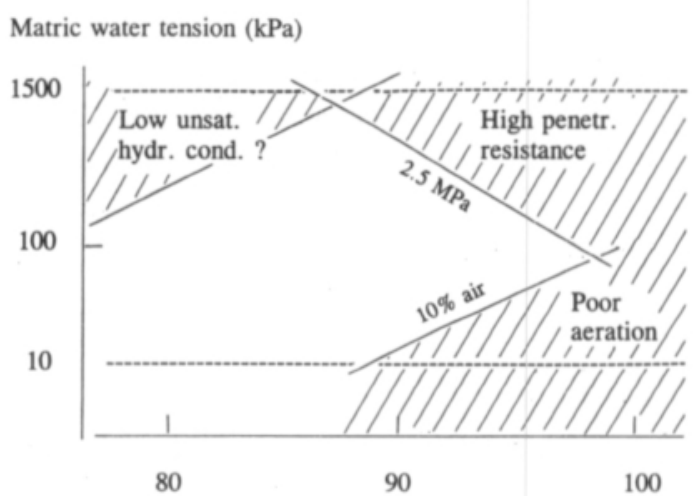

Degree of compactness

Fig. 1. Critical limits for plant growth in relation to degree of soil compactness and matric water potential of the plough layer (Håkansson 1992). Shaded area indicates adverse soil physical properties for plant growth.

sistance and unsaturated hydraulic conductivity for plant growth in relation to both soil moisture and degree of compactness (Fig. 1). The data in Figure 1 is based on the analysis of two Polish loam soils by Lipiec et al. (1991) but, according to the authors, the information is generally applicable to all mineral soils. In organic soils, organic particles may be irreversibly deformed during prolonged loading, resulting in an overestimation of the reference bulk density (Håkansson 1990).

The optimum compactness varies according to plant species, and precipitation at the time of the most intensive yield production is a decisive factor (Soane 1992). In the Nordic countries, most of the precipitation during growing seasons falls at the end of the summer. Consequently, a high state of soil compactness may affect most adversely crop production of late species, such as potatoes and root crops. For these crops, the disadvantages of soil compaction are commonly prevented by preparing very loosely packed raised beds or narrow ridges (Millette et al. 1981). The bed cultivation system is often carried out with a controlled traffic system using permanent traffic lanes (Monroe and Taylor 1989). Water deficit may, however, occur soon- 


\section{AGRICULTURAL SCIENCE IN FINLAND}

Pietola, L.: Effect of soil compactness on the growth and quality of carrot

er in raised beds than on flat land (Mahrer and Avissar 1985). This is well in agreement with the above mentioned low hydraulic conductivity and water retention capacity of loosely packed soils.

\section{I.2 Significance of soil properties to carrot rooting and yield quality}

Carrot growth and yield quality are excellent indicators of soil compactness, as the external quality of carrot tap root is sensitive to soil compaction, even on organic soils (Strandberg and White 1979). Mechanical impedance and poor aeration of compacted soil restricts the carrot root size and modifies the root, making it conical. Followed by young carrot root buckling, branching and thickening (Strandberg and White 1979), the number of short, thick and branched tap roots is high under compacted soil conditions (White 1978, Taksdal 1984, Kesik 1990). On the other hand, tap root yield (Olymbios and Schwabe 1977, Agung and Blair 1989) and seedling emergence (Strzalka 1990) are reduced by excess soil loosening.

The role of soil chemical and physical properties in the internal quality of carrots is minor or may not be well understood. Although placement fertilization (Evers 1989a) and drought (Dragland 1978) have been found to be favourable to carotene production, the developmental stage of carrot has a major influence on the internal quality factors of carrot tap root, such as dry matter, sugar (Platenius 1934, Hole and McKee 1988) and carotene contents (Barnes 1936, Evers 1989a). These and tap root firmness increase along the growing season in developing tap root, indicating root biochemical maturity, i.e. ripeness (Fritz and Habben 1974). Also genotype and weather conditions have a clear impact on carrot internal quality (Bradley and Smittle 1965, Simon et al. 1982, Miedzobrodzka et al. 1993, Evers 1994).
Agung and Blair (1989) reported of poor external quality of carrot tap root and decreased fibrous root length density caused by highly compacted soil but, unfortunately, no data on the internal quality were collected. The total length of carrot fibrous root system increased significantly during the last 50 days before harvest (153 days after sowing) in all pots. The pots were filled by packing homogeneous soil to different dry bulk densities to create artificial soil profiles of very great variation in soil compactness which hardly exist under field conditions with a normal field traffic. Moreover, this study was carried out without any biopores or cracks which contribute to root penetration, but have a limited effect on average soil physical properties, such as mean bulk density or penetrometer resistance. As the thickness of the compact layer represents usually less than $25 \%$ of the final rooting depth of cultivated plants (Tardieu 1994), the effects of localized compact zones on the rooting characteristics of whole-root systems should be emphasized.

\section{I.3 Efficiency of root system}

The response of growth to soil compactness is determined also by root characteristics of a given species. These are root dimensions (length, diameter, surface area) which affect the requirements of carbon (Eissenstat 1992), nutrient and water uptake (Barber and Silberbush 1984), ability to penetrate into soil (Richards and Greacen 1986, Materechera et al. 1991) and capacity to maximize root to soil contact area (Veen et al. 1992).

Root length is the most frequently measured plant property influencing water and nutrient uptake (Nye and Tinker 1977, Molz 1981, Noorwijk and Willigen 1991). Root diameter is also important, as species which have root systems with numerous fine roots containing only a few layers of cells produce more root surface area with less photosynthesized carbon (Eissenstat 


\section{AGRICULTURAL SCIENCE IN FINLAND}

Vol. 4: 139-237.

1992). Moreover, roots with a smaller diameter will have a better nutrient uptake as demonstrated by Itoh and Barber (1983a) for the root diameter range of $0.03-0.3 \mathrm{~mm}$. In addition, fine roots remove more water (Eissenstat and Caldwell 1988a) stored in the soil profile than do larger roots of similar root biomass and distribution with depth. According to Richards and Greacen (1986), fine roots are also less affected by high mechanical impedance, even though in very compacted homogeneous soil (penetrometer resistance 4.2 MPa) there is a positive correlation between root diameter and elongation (Materechera et al. 1991). Noordwijk et al. (1993) found, however, no relation between root-soil contact and root diameter or roundness.

The absorptive capacity of the root system is a product of root surface area and root permeability. According to Fiscus and Markhart (1979), the system size seems to be the dominant and root permeability the minor factor. Also age of the root seems relatively unimportant for the nutrient uptake (Clarkson and Hanson 1980). Root hair lengths less than $0.4 \mathrm{~mm}$ which are common for field crops have a minor effect on ion uptake and water entering as short root hairs do not increase significantly the absorbing surface of roots in the soil (Jones et al. 1983, Barber and Silberbush 1984, McCully and Canny 1989).

Fibrous roots are seldom distributed uniformly within a soil layer (Logsdon and Allmaras 1991, Aiken 1992). Roots tend to preferentially colonize loose zones, between soil aggregates, biopores or other planes of weakness by buckling as a root grows across a macropore and meets a solid surface (Dexter and Hewitt 1978, Pietola 1991). Roots congregate also in the fertile (Eissenstat and Caldwell 1988b) and wetter zones (Smucker 1993). Thus, root characteristics should be quantified from numerous horizontal and vertical soil planes or layers. While non-destructive root sampling by rhizotrons and minirhizotrons (Taylor et al. 1990) offers possibilities to do research on spatial and temporal root dynamics, i.e. root growth and turnover rates, destructive samples are useful for quanti- fying root biomass, length, diameter, surface area and volume at each sampling time (Smucker 1993).

Early root length analyses rely upon Newman's line-intersect method (Newman 1966). Also a core-break method has been used for root length, but it provides only a low precision estimate of root length density (Bland 1989). Automated root intersect counting by video camera imaging (Voorhees et al. 1980) has been extended to root image analyses (length, width, branching) by using a scanner and a microcomputer (Zoon and Tienderen 1990, Pan and Bolton 1991, Ewing and Kaspar 1993). For recording projected root area or root surface area, a video camera and a computer system for digitizing and analysing video images have been developed for clean washed roots (Harris and Campbell 1991, Kokko et al. 1993) and also for washed root samples with residues (Smucker 1993). The image analysis permits examination of root length, diameter and surface area which all are needed for the evaluation of the efficiency of root systems on a morphological basis.

\section{I.4 Background and aim of the present study}

Growth of above-ground biomass in compacted soil has been the subject to much research over many years in the Nordic countries, but mainly on small grains on clay soils. Information about the optimum state of soil compactness for other plant species on different soil types is still needed. For understanding the relations between soil compactness and plant growth, responses of different physical growth factors of soil to both soil loosening and compaction should be quantified on different soil types under varying soil moisture conditions, including impacts on belowground growth.

The disadvantages of soil compaction are better known than the negative effects of inten- 


\section{AGRICULTURAL SCIENCE IN FINLAND}

Pietola, L.: Effect of soil compactness on the growth and quality of carrot

sive soil loosening, especially in vegetable production where the bed cultivation system has been applied extensively. This cultivation technique aims at even and high-quality products. However, even if the external quality of carrot benefits from loose soil conditions, the question so far unanswered is: "To what extent and how is the carrot internal quality affected". Since water and nutrients are absorbed through roots, an extensive functioning root system is of primary importance to plant growth. If the distribution of fibrous root surface area were not adversely affected by moderate soil compaction, comparison of loose and slightly compacted soil conditions would suggest more intensive ripening (i.e. carotene and sugar synthesis) in slightly compacted soil where the soil to root contact and the soil moisture retention capacity are higher. Therefore, quantitative information about the interaction of soil compactness and moisture on carrot rooting and yield quality under field con- ditions is desirable, with special reference to internal quality factors.

The objective of this study was to evaluate the response of carrot growth and quality to the soil compactness of different soil types under different soil moisture conditions. Field experiments were conducted:

1) To determine the alterations of soil compactness and physical growth factors (soil water, mechanical impedance, aeration) induced by soil loosening, partial compaction and irrigation.

2) To identify the changes in carrot growth and quality caused by soil compactness, emphasizing tap root size, shape and ripeness (dry matter content, firmness, sugar and carotene content).

3) To evaluate the role of carrot fibrous root system in the response of carrot biochemical maturity to the soil compactness.

\section{Materials and methods}

\section{I Experimental fields}

The empiric data was collected from three field experiments established at the Agricultural Research Centre of Finland in Jokioinen $\left(60^{\circ} 49^{\prime} \mathrm{N}\right.$; $23^{\circ} 28^{\prime} \mathrm{E}$ ) on undifferentiated Spodosols (Foth 1990) (Appendixes 1-3). The experiment on fine sand soil was set up in all experimental years (1989-1991), but the experiment of clay soil rich in organic matter was conducted only in 1989. These two fields were situated in the same field area. The third field, a mull soil (mixture of peat and clay), was studied in 1990-1991, and it was situated around $10 \mathrm{~km}$ away from the other two fields. The sown area was $1040 \mathrm{~m}^{2}$ for the experiments of sandy and clay soils and $520 \mathrm{~m}^{2}$ for organic soil.

Topsoil (i.e. plough layer) and subsoil samples were taken from all four blocks of the experimental fields. In fine sand, the thickness of topsoil was approximately $25 \mathrm{~cm}$, that of clay soil $26 \mathrm{~cm}$, and that of mull soil $27 \mathrm{~cm}$. The samples were analysed for particle size distribution by the method of Elonen (1971) and for organic carbon content by a Leco analyzer at $1370^{\circ} \mathrm{C}$ (Sippola 1982) (Table 1). According to the soil classification used in Finland (Juusela and Wäre 1956), the topsoil of the sandy field was loamy fine sand. Even though the topsoil of clay field had a high clay fraction, it had $9.4 \%$ organic matter, as the organic carbon content was multiplied by 1.724 (Allison 1969). Hence, this soil type could be used for carrot production and for the purposes of this study. The mull field was rich in clay fraction which made it susceptible to compaction.

The experimental soils were analysed for potassium, phosphorus, calcium and magnesium 
Vol. 4: 139-237.

Table 1. Particle size distribution and organic $\mathrm{C}$ of fine sand, clay and mull at experimental site (\%).

\begin{tabular}{lllllllll}
\hline $\begin{array}{l}\text { Soil } \\
\text { depth, cm }\end{array}$ & \multicolumn{7}{c}{ Particle size fractions $(\mu \mathrm{m})$} & \\
\cline { 2 - 7 } & \multicolumn{2}{c}{$2-$} & $6-$ & $20-$ & $60-$ & $200-$ & $600-$ & Org. C \\
\hline Fine sand & 6 & 20 & 60 & 200 & 600 & 2000 & \\
$0-25$ & 13 & 3 & 4 & 9 & 33 & 36 & 2 & 2.4 \\
$25-50$ & 31 & 6 & 7 & 16 & 23 & 16 & 1 & 0.9 \\
Clay & & & & & & & & \\
$0-26$ & 75 & 7 & 5 & 7 & 3 & 2 & 1 & 5.8 \\
$26-50$ & 78 & 6 & 6 & 7 & 2 & 1 & 0 & 0.7 \\
Mull & & & & & & & & \\
$0-27$ & 81 & 7 & 4 & 4 & 1 & 2 & 2 & 18.1 \\
$27-50$ & 85 & 7 & 4 & 3 & 1 & 0 & 0 & 6.9 \\
\hline
\end{tabular}

extractable in acid ammonium acetate ( $\mathrm{pH} 4.65)$ (Vuorinen and Mäkitie 1955, Kurki et al. 1965), and $\mathrm{pH}$ and electrical conductivity (EC) in water suspension, at the Institute of Soils and Environment at the Agricultural Research Centre of Finland. The boron content was determined by the azomethine-H method (Sippola and Erviö 1977). These characteristics of experimental topsoils and subsoils before (April 1989, for mull 1990) and after (November 1991) the study are presented in Table 2. At the beginning of the field experiments the nutrient contents for fine sand

Table 2. Chemical characteristics of experimental soils before (a) and after (b) field establishment.

\begin{tabular}{|c|c|c|c|c|c|c|c|c|}
\hline \multirow{2}{*}{$\begin{array}{l}\text { Soil } \\
\text { depth, cm }\end{array}$} & & \multirow[t]{2}{*}{$\mathrm{pH}$} & EC & $\mathrm{Ca}$ & $\mathrm{K}$ & $\mathrm{Mg}$ & $\mathrm{P}$ & B \\
\hline & & & $10 \mathrm{mS} \mathrm{cm}^{-1}$ & \multicolumn{4}{|c|}{$\mathrm{mg} \mathrm{dm}^{-3}$ air-dried soil } & \\
\hline \multicolumn{9}{|l|}{ Fine sand } \\
\hline \multirow[t]{2}{*}{$0-25$} & a & 6.8 & 0.65 & 2510 & 210 & 112 & 81.8 & 0.94 \\
\hline & b & 6.7 & 0.68 & 2240 & 125 & 129 & 70.5 & 1.42 \\
\hline \multirow[t]{2}{*}{$25-50$} & a & 6.9 & 0.55 & 2000 & 151 & 147 & 21.8 & 0.73 \\
\hline & b & 6.9 & 0.74 & 2350 & 145 & 651 & 6.2 & 0.60 \\
\hline \multicolumn{9}{|l|}{ Clay } \\
\hline \multirow[t]{2}{*}{$0-26$} & a & 6.3 & 0.83 & 4200 & 452 & 742 & 18.9 & 1.35 \\
\hline & b & 6.3 & 0.71 & 4230 & 436 & 765 & 19.5 & 1.43 \\
\hline \multirow[t]{2}{*}{$26-50$} & a & 6.4 & 0.64 & 3250 & 272 & 1146 & 2.8 & 0.70 \\
\hline & b & 6.4 & 0.70 & 3390 & 276 & 1265 & 4.4 & 0.71 \\
\hline \multicolumn{9}{|l|}{ Mull } \\
\hline \multirow[t]{2}{*}{$0-27$} & $\mathrm{a}$ & 5.5 & 0.46 & 2470 & 290 & 232 & 5.8 & 0.50 \\
\hline & b & 5.3 & 1.33 & 2450 & 235 & 221 & 7.6 & 0.94 \\
\hline \multirow[t]{2}{*}{$27-50$} & a & 5.4 & 0.59 & 2530 & 266 & 266 & 4.1 & n.d. ${ }^{1)}$ \\
\hline & b & 5.6 & 1.20 & 2650 & 189 & 818 & 3.7 & 0.40 \\
\hline
\end{tabular}

${ }^{1)}$ n.d. = not determined 


\section{AGRICULTURAL SCIENCE IN FINLAND}

Pietola, L.: Effect of soil compactness on the growth and quality of carrot

and clay soils were good on average, even though the magnesium content in sandy soil was only fairly good, according to the common classification used in Finland (Soil Testing Laboratory of Finland 1990). In mull, both phosphorus and boron contents were only fairly good.

\subsection{Treatments}

The field experiments were established as a splitplot design with four replicates (Appendixes 13 ). The effects of irrigation were studied in the main plots which were divided into five subplots according to different soil mechanical treatments before sowing as follows:

A. Sprinkler irrigation

$\mathrm{A}_{0}=0 \mathrm{~mm}$

$\mathrm{A}_{1}=2 \times 30 \mathrm{~mm}$

B. Mechanical treatment

\section{Loosening}

$\mathrm{B}_{1}=$ narrow ridges

$\mathrm{B}_{2}=$ rotary harrowing

$\mathrm{B}_{3}=$ no traffic (untreated)

Compaction

$\mathrm{B}_{4}=$ one pass of the tractor wheel

$B_{5}=$ three passes of the tractor wheel

\subsection{Irrigation}

Irrigation treatments were studied in sandy and clay soils and consisted of no irrigation $\left(\mathrm{A}_{0}\right)$ and sprinkler irrigation $\left(A_{1}\right)$. Irrigation $\left(A_{1}\right)$ was not performed on mull. One irrigation of around $30 \mathrm{~mm}$ was given when the water content at a depth of $15 \mathrm{~cm}$ had been depleted to around $50 \%$ of the plant-available water capacity, as measured by the gypsum block method (see 2.5.1).

Irrigation was performed at night by rotary sprinklers (radius $14 \mathrm{~m}$ and angle of irrigated sector $90^{\circ}$ ). Thus, one sprinkler was needed to irrigate each main plot. Rate of irrigation was 5 $\mathrm{mm}$ per hour. The amount of water given to every sprinkling sector was controlled by eight plastic flasks eguipped with funnels (Elonen et al. 1967). The dates of irrigation and quantities of water applied are presented in Appendixes 1-2. The water applications were rather uniform inside the main plots with a variation less than $20 \%$ (1989), 15\% (1990) or 25\% (1991).

\subsubsection{Soil mechanical treatments}

Spring tillage treatments in the sub-plots were set up on autumn ploughed land, by loosening $\left(\mathrm{B}_{1}-\mathrm{B}_{2}\right)$ or compacting $\left(\mathrm{B}_{4}-\mathrm{B}_{5}\right)$ the experimental field area before fertilization and sowing. All tractor operations were performed by the controlled traffic concept. The distance of both the rear and front wheels was adjusted to $2 \mathrm{~m}$ which was the width of the sub plots. The tractor wheel was never allowed to compact the experimental area in treatments $B_{1}-B_{3}$.

\section{Soil loosening}

After harrowing to the depth of $5 \mathrm{~cm}$, four narrow ridges were prepared for treatment $B_{1}$ by means of coulters used for potato planting. The ridge tops were slightly compacted by rolling $(10 \mathrm{kPa})$ to the state which could carry the sowing units. The final height of the loose ridges was around $10 \mathrm{~cm}$ and the ridge distance $45 \mathrm{~cm}$, which was the carrot row distance in all subplots. In 1991, the ridges were $1-2 \mathrm{~cm}$ higher than in 1989-1990 because the design and the compaction of ridges were repeated. In the $\mathrm{B}_{2}$ plots, the soil was loosened by a rotary harrow to a depth of $20 \mathrm{~cm}$ (clay $15 \mathrm{~cm}$ ). The top surface was afterwards slightly compacted by a roller.

\section{Soil compaction}

For treatments $\mathrm{B}_{4}-\mathrm{B}_{5}$, wheel traffic was imposed on ploughed land by a tractor with a harrow which was kept up. In treatment $B_{4}$, the subplot 
Vol. 4: 139-237.

was established by consecutive passes across the plot with the rear wheels compacting the entire subplot. Because the track distance was kept at $2 \mathrm{~m}$, and the width of one rear wheel was $33 \mathrm{~cm}$, six passes compacted a 4-m wide lane. A buffer zone of $2 \mathrm{~m}$ was left at the outer sides of the main plots (Appendixes 1-3). In treatment $\mathrm{B}_{5}$, the subplots were recompacted twice ( 18 drives). The rear axle load of the tractor with the harrow was $3030 \mathrm{~kg}$. Because the diameter of the rear wheel was $145 \mathrm{~cm}$, the contact area of the rear wheel was $1290 \mathrm{~cm}^{2}$ according to the equation of Inns and Kilgour (1978, ref. Soane et al. 1980):

$$
S=0.87 b_{c} \times 0.31 d_{c}
$$

where $\mathrm{S}$ is the contact area, $\mathrm{b}_{\mathrm{c}}$ the section width and $d_{c}$ the diameter of a wheel. This equation is designed for a hard surface. Because the soil surface of clay and mull sank during the first pass, this equation could not be applied to these soil types in treatment $\mathrm{B}_{4}$, but it was applicable to all soils after the first pass. According to equation (2), the ground pressure of the rear wheel was $120 \mathrm{kPa}$, that of the front wheel $60 \mathrm{kPa}$. The pressures used in the present study were low as compared to those applied, e.g. in the United States where the ground pressures of agricultural vehicles can be as high as $490 \mathrm{kPa}$ (Gupta and Larsson 1985).

\subsection{Establishment and manage- ment of field experiments}

Prior to establishing the experiments in early spring when soil was moist and susceptible to compaction, the entire study area was ploughed to a depth of $25-26 \mathrm{~cm}$ each autumn. The first operation was 1-3 passes with a tractor wheel, which was carried out under the same moisture conditions each experimental year. Soil compaction and sowing dates are presented in Appendixes 1-3,

\subsection{Fertilization and spring tillage}

After soil compaction, fertilizers were drilled at the rates of $\mathrm{N} 80, \mathrm{P} 50, \mathrm{~K} 160 \mathrm{~kg}$ per hectare to fine sand and clay, and N 30, P 70, K $170 \mathrm{~kg}$ per hectare to mull, in accordance with general recommendations (Soil Testing Laborotory of Finland 1990). In fine sand and clay fields, the compound fertilizer was applied with a fertilizer drill to the soil surface. In mull, nitrogen was broadcasted. The fertilizers were harrowed in treatments $B_{1}$ and $B_{3}-B_{5}$ to the depth of $5 \mathrm{~cm}$, being $1-2 \mathrm{~cm}$ shallower in the most compacted treatments. After harrowing, the loosening treatments $\mathrm{B}_{1}$ and $\mathrm{B}_{2}$ were performed (see 2.2.2).

\subsubsection{Sowing and management during growth}

For one subplot, seeds were sown in four row beds $10 \mathrm{~m}$ long with $45 \mathrm{~cm}$ between rows. The carrot (Daucus carota $\mathrm{L}$.) cultivar grown in these experiments was Nantes Duke Notabene $370 \mathrm{~Sv}$ which has been used also in other carrot investigations in the Nordic countries concerning land preparation (Taksdal 1984) and fertilization (Evers 1988). Seeds (in 1989-1990 coated) were sown $1 \mathrm{~cm}$ deep and $6 \mathrm{~cm}$ wide with a Nibex sowing machine with four units. The seeding depth ranged $0.5-1.5 \mathrm{~cm}$, with a greater depth on loose organic soil and smaller depth on compacted clay soil. In 1991, a pneumatic Gaspor machine was used to avoid gaps in the loose subplots. Later, thinning was done at the same time for all plots of one field to 40 plants per $1 \mathrm{~m}$. However, in 1989, emergence on clay was uneven and slow due to the lack of rains following planting although the whole field was irrigated $(5 \mathrm{~mm})$. Plant populations were thinned to 20 plants per metre.

Weeds were sprayed with linuron (only in 1989) and methoxuron (1990-1991). In addition, setoxidim was used for protection against couch grass (1989-1990). Couch grass was a problem especially in the clay soil field. Also hand weed- 
Pietola, L.: Effect of soil compactness on the growth and quality of carrot

Table 3. Weather conditions in Jokioinen in 1989-1991 and 30-year averages.

\begin{tabular}{|c|c|c|c|c|c|c|c|c|}
\hline \multirow[t]{2}{*}{ Month } & \multicolumn{4}{|c|}{ Mean air temperature $\left({ }^{\circ} \mathrm{C}\right)$} & \multicolumn{4}{|c|}{ Precipitation (mm) } \\
\hline & 1989 & 1990 & 1991 & $(1961-91)$ & 1989 & 1990 & 1991 & $(1961-91)$ \\
\hline April & 5.3 & 5.6 & 3.4 & ( 2.4) & 40 & 35 & 14 & (31) \\
\hline May & 10.4 & 9.3 & 7.2 & ( 9.4) & 41 & 22 & 29 & $(35)$ \\
\hline June & 15.4 & 14.4 & 12.1 & $(14.3)$ & 30 & 20 & 69 & (47) \\
\hline July & 16.3 & 15.2 & 16.6 & $(15.8)$ & 85 & 85 & 55 & $(80)$ \\
\hline August & 13.7 & 15.0 & 16.2 & $(14.2)$ & 92 & 90 & 92 & $(83)$ \\
\hline September & 11.0 & 8.0 & 9.1 & ( 9.4$)$ & 51 & 62 & 80 & $(65)$ \\
\hline \multirow[t]{2}{*}{ October } & 4.7 & 4.9 & 5.4 & $(4.7)$ & 49 & 48 & 49 & (58) \\
\hline & $\begin{array}{l}\text { Mean: } \\
11.1\end{array}$ & 10.3 & 10.0 & $(10.0)$ & $\begin{array}{l}\text { Sum: } \\
388\end{array}$ & 362 & 388 & (399) \\
\hline
\end{tabular}

ing was carried out during the growing season as needed. Dimethoate was applied 3-4 times against carrot psyllit, Iriosa apicalis, at the beginning of the growing season. Carrot fly, Psila rosae, was controlled by traps.

\subsubsection{Sampling}

Both ends of each subplot were used for soil and plant sampling (Appendix 4). The final carrot yield was measured from an area in the middle of each sub-plot (length $6 \mathrm{~m}$ ) where no sampling had been carried out. Because the sampling areas used for the cylinders in 1989-1990 were no more useful due to mixed soil, an exception was made in 1991. The plastic cylinders for root sampling (see 2.7) were fixed inside the yield area of subplots for treatments $\mathrm{B}_{2}$ and $\mathrm{B}_{5}$. From four carrot rows, only the two inner rows were used for plant sampling and harvest.

\subsection{Weather conditions}

After the dry early season in 1989 , the growing season was favourable for growth. Precipitation was slightly higher than normal in July and August, and September was very warm (Table 3). In 1990 , like in 1989 , the soils were too dry for good emergence. Dry June was followed by a moderately rainy season, and August was warm. September was, however, cooler than in 1989 , with a difference of $3^{\circ} \mathrm{C}$ in mean temperature. In 1991, the soils were moist enough during emergence which was, however, much slower than in 1989-1990 because of low temperatures in May and June. Only late July was dry. During the warm and rainy autumn, carrot growth was very intensive and recovered soon after the cool early season of 1991 .

\subsection{Soil measurements}

\subsection{Soil water content}

\section{Electrical resistance}

The moisture condition of the soil during the growing season was studied by the gypsum block method (Bouyoucos 1954). Immediately after sowing in 1989, blocks were dug to a depth of $15 \mathrm{~cm}$ in subplots $B_{1}, B_{3}$ and $B_{5}$ (Appendix 4). 
Vol. 4: 139-237.

In 1990 , the blocks were also placed to $30 \mathrm{~cm}$. In 1991, blocks were placed in all subplots to both depths. Blocks were located in the wall of a hole $8 \mathrm{~cm}$ in diameter. After filling the holes, some seeds were resown. In fine sand and clay, electric resistances of gypsum blocks were measured 2-3 times a week, but only once a week in organic field where the moisture condition varied least. According to measurements in a pressure chamber, the blocks used in 1989 registered soil water contents of $93-94 \%$ of plant-available water at field capacity (matric potential of $-10 \mathrm{kPa}$ ), whereas new blocks used in 19901991 showed only $89-90 \%$. According to Aura (1985), this type of gypsum blocks register the wilting point $(-1500 \mathrm{kPa})$ at $5 \%$.

\section{Sampling and drying}

In addition, soil water content was determined by gravimetric analysis $\left(105^{\circ} \mathrm{C}\right)$. On the compaction day, immediately before mechanical treatments, undisturbed soil cores $5.05 \mathrm{~cm}$ in inside diameter were obtained from $\mathrm{B}_{3}$ plots at $2.5-\mathrm{cm}$ intervals from a depth of $0-20 \mathrm{~cm}$ and at 5 -cm intervals from a depth of $20-40 \mathrm{~cm}$ using a soil core sampler (Heinonen 1960). Samples of top soil were taken with two replicates per plot $\left(2 \times 50 \mathrm{~cm}^{3}\right)$. Later this sampling method was used together with the measurements of gamma ray transmission (see 2.5.2) and penetrometer resistance (see 2.5.4). Additionally, in 1991 the effect of soil mechanical treatments on soil moisture before emergence was studied by means of this core sampling.

\subsubsection{Soil dry bulk density}

\section{Gravimetric analyses}

Dry soil bulk density was determined by gravimetric analysis (ratio of soil dry weight to its total volume) from core samples which were also used for soil water contents and pore size distribution (see 2.5.1 and 2.5.5).

\section{Gamma ray transmission}

In 1990, the dry bulk densities of fine sand and mull were measured to a depth of $35 \mathrm{~cm}$ at $2.5-\mathrm{cm}$ intervals according to the principle of gamma emission using a French signal generator (Stengel et al. 1986). Before soil irradiation, two parallel tubes of aluminium (one for a source of radiation, another for crystal indicator, inside diameter $3.5 \mathrm{~cm}$, length $40 \mathrm{~cm}$, distance from each other $30 \mathrm{~cm}$ ) were fixed in soil. During the measurement, soil was irradiated with a source of ${ }^{137} \mathrm{Cs}$, and the quantity of photons transmitted through the soil, during 30 seconds, was recorded by a counter. The determined soil length was $30 \mathrm{~cm}$ and the maximum radius of effective volume of measurement $2 \mathrm{~cm}$ (Stengel et al. 1986). The maximum radius was located in the middle of the irradiated area, where the gravimetric measurement of soil water content was made $(2 \times$ $50 \mathrm{~cm}^{3}$ ).

The relation between the quantity of photons and the bulk density of a substance was determined in two substances of which the densities were known, an organic substance named Technyl $\left(\rho=1.26 \mathrm{~g} \mathrm{~cm}^{-3}\right)$ and concrete $(\rho=$ $\left.2.49 \mathrm{~g} \mathrm{~cm}^{-3}\right)$. The equation of calibration for the tube distance of $30 \mathrm{~cm}$ and transmission time 30 seconds, was determined as:

$$
\rho_{c}=-0.664 \ln \mathrm{C}+5.96
$$

where $\rho_{c}$ is the bulk density of a substance in a certain moisture condition and $\mathrm{C}$ the number of photons per second penetrating the substance. The effects of soil water content were eliminated by means of the equation of Double-sonde Gammametrique L.P.C.-I.N.R.A. (1985) and Stengel et al. (1986):

$$
\rho_{\mathrm{b}} \approx \rho_{\mathrm{c}} /(1+1.1 w)
$$

where $\rho_{\mathrm{b}}$ is the dry bulk density and $w$ is the soil gravimetric water content. For $w$, the gravimetric water content in soil between the aluminium 


\section{AGRICULTURAL SCIENCE IN FINLAND}

\section{Pietola, L.: Effect of soil compactness on the growth and quality of carrot}

tubes was analysed at $2.5-\mathrm{cm}$ intervals by the sampler of Heinonen (1960) after irradiation (see 2.5.1). In all measurements, a tube distance of $30 \mathrm{~cm}$ was used. At this distance, high soil water contents do not interfere with soil density analyses (Stengel et al. 1986). According to the measurements in Avignon (Double-sonde Gammametrique L.P.C.-I.N.R.A. 1985), the empiric relation is rectilinear between densities of 1 and $2.5 \mathrm{~g} \mathrm{~cm}^{-3}$. In the present study, the bulk densities were within these limits, even in loose organic soil where the "moist densities" $\left(\rho_{c}\right)$ were twice as high as the moisture-corrected dry bulk densities $\left(\rho_{\mathrm{b}}\right)$.

\subsubsection{Degree of soil compactness}

For determination of dry bulk density $\left(\rho_{d}\right)$ for fine sand and mull, dry bulk densities at the soil depth of 7.5-17.5 $\mathrm{cm}$ were averaged, based on the $50-\mathrm{cm}^{3}$ coring and gamma ray transmission (see 2.5.2) in July-August 1990. Dry bulk densities from depths of $2.5-7.5 \mathrm{~cm}$ and 12.5 $17.5 \mathrm{~cm}$, based on $200-\mathrm{cm}^{3}$ coring in September 1989 and 1990, were averaged for comparison including clay.

For the determination of dry bulk density at the reference state $\left(\rho_{\mathrm{d}, \mathrm{p}}\right)$, a soil sample from each field experiment replicate was collected from the plough layer $(20 \times 20 \times 25,26$ or $27 \mathrm{~cm}$ for fine sand, clay and mull, respectively) in May 1991. For the preparation of a sample representing one field, four moist samples were pooled and $40 \mathrm{dm}^{3}$ of soil was kept in a plastic bag to retain the moisture until analysed in Sweden at the Agricultural University of Uppsala by the method of Håkansson (1990). A soil sample $\left(30 \mathrm{dm}^{3}\right)$ of a moisture of field capacity was compacted by an unaxial pressure of $200 \mathrm{kPa}$ (surface area of soil $0.1 \mathrm{~m}^{2}$ ) for about one week, until no water came out from the water outlet. The maximum soil dry bulk density was then analysed with four replicates. The degree of soil compactness $(\mathrm{D}=$ $\left.100 \rho_{\mathrm{d}} / \rho_{\mathrm{d}, \mathrm{p}}\right)$ was then expressed for different mechanical treatments.

\subsubsection{Soil penetrometer resistance}

A recording cone penetrometer described by Anderson et al. (1980) was used to measure soil mechanical impedance to a depth of $52 \mathrm{~cm}$ at $3.5-\mathrm{cm}$ intervals. The kilograms shown by the penetrometer were converted into pascals with the coefficient 76.2 , as the diameter of cone was $1.29 \mathrm{~cm}$ (Instruction Manual for Use of Bush Recordings Soil Penetrometer 1979). The cone index in the profile of each subplot was measured four times, from two inner rows at both ends near the area reserved for yield measurements. The medians were calculated from four measurements of two inner rows. Medians were used instead of means because of high spatial variability in penetrometer resistances of subsoil. In 1989 , the penetrometer resistance was measured only once, at the time of vigorous growth of carrot tap roots, with only gypsum block recordings for soil water content. In 1990-1991, the cone indexes were taken three times per season, simultaneously with gravimetric determination of soil water content.

\subsubsection{Soil pore size distribution}

Undisturbed soil cores (inside diameter $7.1 \mathrm{~cm}$, height $5 \mathrm{~cm}$ ) were collected in metal cylinders of $200 \mathrm{~cm}^{3}$ in autumn before harvest between two inner carrot rows in the sampling area. The sampling depths were $2.5-7.5 \mathrm{~cm}, 12.5-17.5 \mathrm{~cm}$, $22.5-27.5 \mathrm{~cm}$ and $32.5-37.5 \mathrm{~cm}$. In 1989 , only one sample per each subplot $\left(\mathrm{B}_{2}-\mathrm{B}_{3}-\right.$ or $\left.\mathrm{B}_{5}\right)$ was taken at a given depth, but in 1990 the samples were collected from all subplots with two replicates. Samples of treatment $B_{1}$ were taken only from two upper layers and near the carrot row.

Pore size was divided into three categories: $>30 \mu \mathrm{m}, 0.2-30 \mu \mathrm{m},<0.2 \mu \mathrm{m}$. These equivalent pore diameters corresponding to the matric potentials of $-10 \mathrm{kPa}$ to $-1500 \mathrm{kPa}$ were calculated on the basis of the corresponding matric suctions and effective pore size drainage using the capillary rise formula (e.g. Aura 1975): 
Vol. 4: 139-237.

$$
\mathrm{d}=0.3 / h
$$

where $\mathrm{d}$ is the equivalent pore diameter $(\mathrm{cm})$ and $h$ is the pressure head $(\mathrm{cm})$, i.e.

$$
h=2 \gamma \cos \alpha / \mathrm{r} \rho_{1} \mathrm{~g}
$$

where $\gamma$ is the surface tension between the liquid (water) and the air, $\alpha$ the contact angle (for pure water and clean surfaces $\alpha \rightarrow 0$ ), $\mathrm{r}$ the radius of the capillary, $\rho_{1}$ the density of liquid water and $g$ the acceleration of gravity (e.g. Hillel 1971). Later, the pressure head $(h)$ is termed matric potential $\left(\psi_{\mathrm{m}}\right)$.

For determination of soil moisture at field capacity $\left(\psi_{\mathrm{m}}=-10 \mathrm{kPa}\right)$, samples in metal cylinders were saturated by wetting from the bottom, the water level being in the middle of the soil core. Cylinders were placed into a pressure chamber, using the equipment described by Aura (1983).

Soil water retention at the matric potential of wilting point $\left(\psi_{\mathrm{m}}=-1500 \mathrm{kPa}\right)$ was determined using a tension caused by osmosis (Aura 1975). After premoistening, samples $(9 \mathrm{~g})$ from metal cylinders of $5 \mathrm{~cm}^{3}$ collected in the field near the large cylinders were placed into semipermeable plastic tubes in polyethylene glygol solution. After two weeks, soil water contents in samples of potentials of -10 and $-1500 \mathrm{kPa}$ were analysed gravimetrically. Soil-specific densities were determined by pycnometry (Blake 1965).

\subsubsection{Soil air composition}

Soil oxygen and carbon dioxide contents were measured at the depths of $15 \mathrm{~cm}$ (1989-1990) and $30 \mathrm{~cm}$ (1990) from both $\mathrm{A}_{0}$ and $\mathrm{A}_{1}$ plots in three replicates. In 1989, air samples were collected from the $\mathrm{B}_{1}, \mathrm{~B}_{3}$ and $\mathrm{B}_{5}$ subplots, whereas in 1990 , subplots $B_{2}$ (the most loose soil) and $B_{5}$ were analysed. After sowing, a porous cup (diameter $2.5 \mathrm{~cm}$, height $3.5 \mathrm{~cm}$ ) was placed at the bottom of a hole $2.5 \mathrm{~cm}$ in diamerer in a carrot row in the sampling area, beside a gypsum block
(Appendix 4). During growing seasons, air samples of $1.5 \mathrm{~cm}^{3}$ were taken up from cups by syringes at a constant rate $0.5 \mathrm{~cm}^{3} \mathrm{~s}^{-1}$ (after one extra air sucking) once a week (1989), or every two weeks (1990). Soil water contents were measured by means of gypsum blocks on the day of air sample collection. Air composition was analysed by gas chromatography (Porapak Q and Molecular Sieve 5A columns and TC-detector and He-carrier flow) at the University of Helsinki, Department of Applied Chemistry and Microbiology (Jaakkola et al. 1990, Simojoki et al. 1991). Retention times for $\mathrm{CO}_{2}$ and $\mathrm{O}_{2}$ were 0.61 and 1.36 minutes, respectively.

\subsection{Plant measurements}

\subsection{Sampling}

Carrot tap roots and shoots were sampled from two inner rows in all subplots twice before harvesting from the sampling area and at harvest from the yield area (Appendix 4). The first sample was collected when tap roots began to swell, i.e. 7-8 weeks before harvest. The second sampling was performed 3-4 weeks before harvest, when tap roots were almost full size, but inner quality was still developing (see 1.2). The third sampling was done at the time of harvest.

The fresh weights of shoots and washed tap roots were recorded. After analysis of the external quality (see 2.6.4) of tap roots, they were grated and frozen $\left(-20^{\circ} \mathrm{C}\right)$ in plastic boxes of $500 \mathrm{ml}$ ( 2 boxes per sample) for analysis of internal quality (see 2.6.5). When the sample size was over $1.5 \mathrm{~kg}$, it was not possible to grate the entire sample. Only whole representative carrots were used for grating. An additional frozen sample of carrot slices (300-400 g) was prepared for determination of carotene, but only from samples collected at harvest. In 1989, a sample consisted of 15 shoots or tap roots. In 1990-1992, 
Pietola, L.: Effect of soil compactness on the growth and quality of carrot

20 carrots were sampled due to the great variation among plants. In 1990-1991, only nonbranched and non-split, medium-size roots (50$250 \mathrm{~g}$ ) were used for internal quality analysis.

\subsubsection{Yield}

Harvesting was done by pulling plants manually on 11, 24 and 17 September 1989-1991 from fine sand, and on 15 September 1989 from clay soil field. The mull field was harvested on 2 October 1990 and on 23 September 1991. The sample area for final tap root yield was $12 \mathrm{~m}$, i.e. $6 \mathrm{~m}$ from the two inner rows (Appendix 4). Shoot samples of 15 carrots (1989) or 20 carrots (1990-1991) were taken simultaneously with the tap root harvest.

After harvest, the weights and numbers of non-branched and non-split, branched, split and both branched and split tap roots were recorded. Non-branched and non-split roots were classified together into three size classes: below $50 \mathrm{~g}$, $50-250 \mathrm{~g}$ and over $250 \mathrm{~g}$, and weights and quantities of carrots were recorded per size class.

\subsubsection{Tap root quality}

\section{External quality}

The length and diameter (maximum and $0.5 \mathrm{~cm}$ below crown) of 50 tap roots were measured from final yield for each treatment. In 19901991 , the measurements were performed also from the samples collected before harvest (first and second sampling) of 15-20 non-branched and non-split carrots.

Each non-branched and non-split sample carrot $(n=15-20)$ was weighed separately in order to calculate the cylidrical index (C) (Bleasdale and Thompson 1963) by means of tap root weight $(\mathrm{W})$, length (h) and radius of root top (r) as follows:

$$
\mathrm{C}=\mathrm{W} / \pi \mathrm{r}^{2} \mathrm{~h}
$$

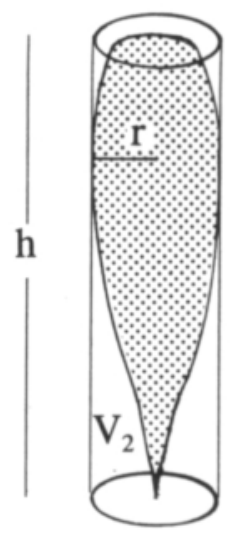

Fig. 2. Cylindrical index of carrot tap root based on tap root fresh weight $\left(\mathrm{W} \approx \mathrm{V}_{1}\right)$ to volume of cylinder $\left(\mathrm{V}_{2}\right)$ ratio. The radius of cylinder (r) represents maximum diameter of tap root, and cylinder height is taproot length $(\mathrm{h})$. A modification of the cylindrical index by Bleasdale and Thompson (1963).

In the present study, tap root diameters at the crown were much smaller than were maximum diameters. Therefore, cylindrical indices were calculated on the basis of maximum diameter (at $2-3 \mathrm{~cm}$ below the crown). The index measured the ratio of root fresh weight $(\mathrm{W})$ and volume $\left(V_{2}=\pi r^{2} h\right)$, i. e. the volume of a cylinder given by carrot length and maximum diameter, as presented in Figure 2. Because carrot contains around $90 \%$ water, root fresh weight is near root volume $\left(\mathrm{V}_{1}\right)$. Thereby, the ratio for a cylindric carrot is near the value of 1 , for a conical root it is near 0.33 (Thompson 1969). A cylindric shape is a characteristic of a Nantes-type carrot and an indication of excellent external quality.

According to Rosenfeld et al. (1984), the sample size for measurements of the cylindricality index of cv. Nantes Duke should be at least 50 carrots to minimize the effect of random variation. Thus, the sample size of the present study, i.e. 20 carrots per replication, might not have been large enough for statistically significant differences between group means. Nevertheless, an average of four replicates represents a sample size large enough. 
Vol. 4: 139-237.

In addition, carrot shape was measured as root length to maximum diameter ratio. The portions of small (below $50 \mathrm{~g}$ ), heavy (over $250 \mathrm{~g}$ ), branched and split roots of the total yield also illustrated the external quality.

\section{Internal quality}

Frozen samples for determination of root internal quality, relating tap root ripeness and biochemical maturity, were analysed after harvest in November-January. Dry matter, crude fibre, juice, juice dry matter, sugar and carotene contents were measured in relation to fresh carrot weight. The dry matter and crude fibre content was analysed on the gravimetric basis $\left(60^{\circ} \mathrm{C}\right.$ $48 \mathrm{~h}, 105^{\circ} \mathrm{C} 24 \mathrm{~h}$ ) (Wilde and Voigt 1955, Jokinen 1977). Crude fibre content, which is a good indicator of root firmness (Aubert et al. 1979) was determined as dry weight of the carrot sample after juice extraction. Juice was spun from carrots with a Moulinex liquidizer at $9000 \mathrm{~g}$ for 10 minutes. Juice content in carrots was also recorded because it is another good indicator of root firmness (Aubert et al. 1979). The dry matter content for carrot juice, i.e. juice density, was analysed by refractometry (Bellingham + Stanley $60 / 95$ ) with glucose calibration from $0-10 \%$ glucose. According to Aura (1985), the dry matter content of carrot juice measured by this method is only slightly higher $(4 \%)$ than the sugar content of carrot juice by colorimetry. A sample size of $100 \mathrm{~g}$ (grated and frozen carrot) was used in the above mentioned analyses.

Sugar and carotene contents were analysed at the Food Research Institute at the Agricultural Research Centre of Finland. Saccharose, glucose and fructose contents were analysed by gas chromatography ( $\mathrm{Li}$ and Schuhmann 1981) only from samples collected at harvest $(100 \mathrm{~g}$ grated and frozen carrot). Alfa and beta carotenes were determined from the tap roots from the harvest ( $300 \mathrm{~g}$ sliced and frozen carrot) by high-performance liquid chromatography (Heinonen et al. 1988). Two subsamples were taken for the analyses.

\subsection{Studies on carrot fibrous root system}

\subsection{Destructive sampling}

In 1990-1991, the distribution and morphology of fibrous root system of full-grown carrots were studied by destructive sampling from large cylinders (inside diameter $30 \mathrm{~cm}$, wall thickness $1.0 \mathrm{~cm}$ ) of polyvinyl chloride (PVC) presented in Figure 3. After plant emergence, these cylinders were pressed into moist soil at the ends of $\mathrm{B}_{2}$ and $\mathrm{B}_{5}$ subplots (Appendix 4). Six carrots were left in each cylinder under field conditions surrounded by carrots growing in the rest of the plots. Cylinders were kept in the field during the growing season and removed manually 1-2 weeks after harvest in 1990 (170 and 180 days after sowing in fine sand and mull, respectively) and in 1991 at harvest (145 days after sowing), in order to measure the root system at full length and close to the time of biochemical maturation (see 1.2).

In October 1990 and September 1991, the plastic walls of the cylinders were sawn length-

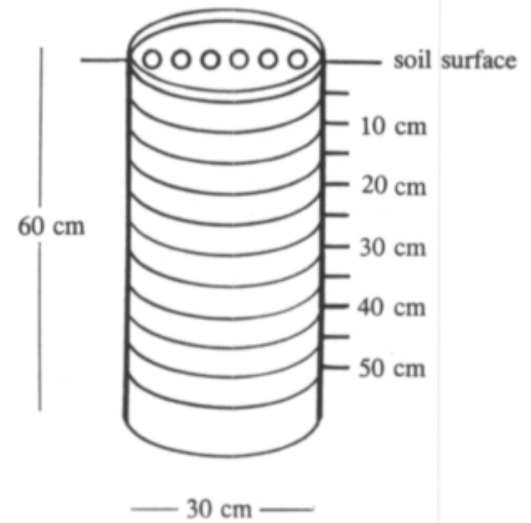

Fig. 3. PVC cylinders for destructive sampling of carrot fibrous root system, placed into the fields for the growing season. Root sampling performed at $5 \mathrm{~cm}$ horizontal soil layers of experimental fields. White circles indicate carrot plants. 


\section{AGRICULTURAL SCIENCE IN FINLAND}

\section{Pietola, L.: Effect of soil compactness on the growth and quality of carrot}

wise along two lines in order not to destroy the soil profile inside the cylinder. One half of the cylinder wall was removed and each soil profile inside the cylinder was partitioned horizontally into $10-12$ cylinders at 5 -cm intervals. For most of the profiles, the two deepest layers below $50 \mathrm{~cm}$ broke as they were removed from the field, and the data were collected only from the 10 first soil layers from a depth of $0-50 \mathrm{~cm}$. Each soil sample consisted of $3534 \mathrm{~cm}^{3}$ soil.

Fibrous roots which were divided into ten strata were then collected with the soil into plastic bags where they were frozen $\left(-20^{\circ} \mathrm{C}\right)$ until separated from soil. Carrot tap roots (i.e. the orange part of the swollen root system, diameter over $1 \mathrm{~mm}$ ) were sliced at the same time with the soil profile, and tap root pieces in each sample were separated from the soil and fine roots. Fresh and dry weights of tap roots were then measured with shoots.

Prior to root separation from soil, the frozen samples were soaked in a solution of $0.015 \mathrm{M}$ $\mathrm{NaOH}$ to disperse the clay and to wash the roots. The soil was washed from the root samples with a hydropneumatic elutriatior (Smucker et al. 1982) which separated any organic material which was less dense than the mineral fraction of the soil, retaining up to $99.4 \%$ of all roots $>0.05 \mathrm{~mm}$. Thus, a lot of debris was included with extracted fine roots especially in the samples from the mull soil.

Based on the determination of debris dry weight during video recording (see 2.7.3), the purity of sandy soil samples was $90 \%$ on dry weight basis after some manual pre-cleaning. Organic debris associated with the root samples from the fine sand were manually removed so that only $0.6 \%$ of the total debris remained with the root sample during image analysis. In the mull soil samples, the amount of debris was very high. Even after some precleaning based on sedimentation in water, the root content was $35 \%$ in 1990 , and $50 \%$ in 1991 . The major non-root residue was straw material from the oat crop in 1989. It took a lot of time (2-4 hours per sample) to clean these samples for image analysis. Yet, in video recording, 19\% (1990) and 9.5\%
(1991) of the debris was left, but only short straw and peat material, which was not included in the final analysis of root dry weight, root length density or root surface area (see 2.7.3).

Root samples for image analysis were mailed (5 days) in 50-100 $\mathrm{ml}$ of $15-20 \%$ ethanol to Michigan State University (USA) where the roots were cleaned and video recorded by the end of the same year 1993, meanwhile storing the samples in the same solution at $4^{\circ} \mathrm{C}$. Root samples of 1990 from sandy field were not included in the image analysis in the USA because these roots were used for dry weight analysis at the Agricultural Research Centre of Finland in 1992.

Similarly, in 1989, some prestudies for fibrous root growth were performed on fine sand and clay soil. At that time, the PVC cylinders were lifted up from the field after carrot emergence and placed on wet coarse sand. During the warm and dry summer, the soil temperature was as high as $26^{\circ} \mathrm{C}$ at the depth of $15 \mathrm{~cm}$, and the soil moisture status varied $(35-50 \% \mathrm{v} / \mathrm{v})$. This resulted in abnormal forking of tap roots, even in loose soil, and some fibrous root accumulation on the cylinder wall and cracks (Fig. 4). These samples were washed manually by sieving in water. Otherwise these root samples were collected as described above. Results for fibrous root dry weight distribution in clay soil are given only for 1989 because no measurements of this soil type were performed after that year.

\subsubsection{Dry weight}

For fibrous roots from mineral soils in 19891990 , dry weight determination $\left(48 \mathrm{~h}\right.$ at $60^{\circ} \mathrm{C}$, $24 \mathrm{~h}$ at $105^{\circ} \mathrm{C}$ ) was performed after final cleaning, 1-3 days storing at $4^{\circ} \mathrm{C}$ (1989 in water, 1990 in $100 \mathrm{ml}$ of $0.1 \%$ formaldehyde) and wrapping in a cloth. The decrease of dry weight given by the extra drying at $105^{\circ} \mathrm{C}$ averaged $3 \%$ for fibrous roots and $5 \%$ for shoots. The weight loss was as much as $10 \%$ for tap roots because of the large quantities of the material which had not dried completely during the first drying period at $60^{\circ} \mathrm{C}$. Fresh and dry weights of tap roots col- 
Vol. 4: 139-237.
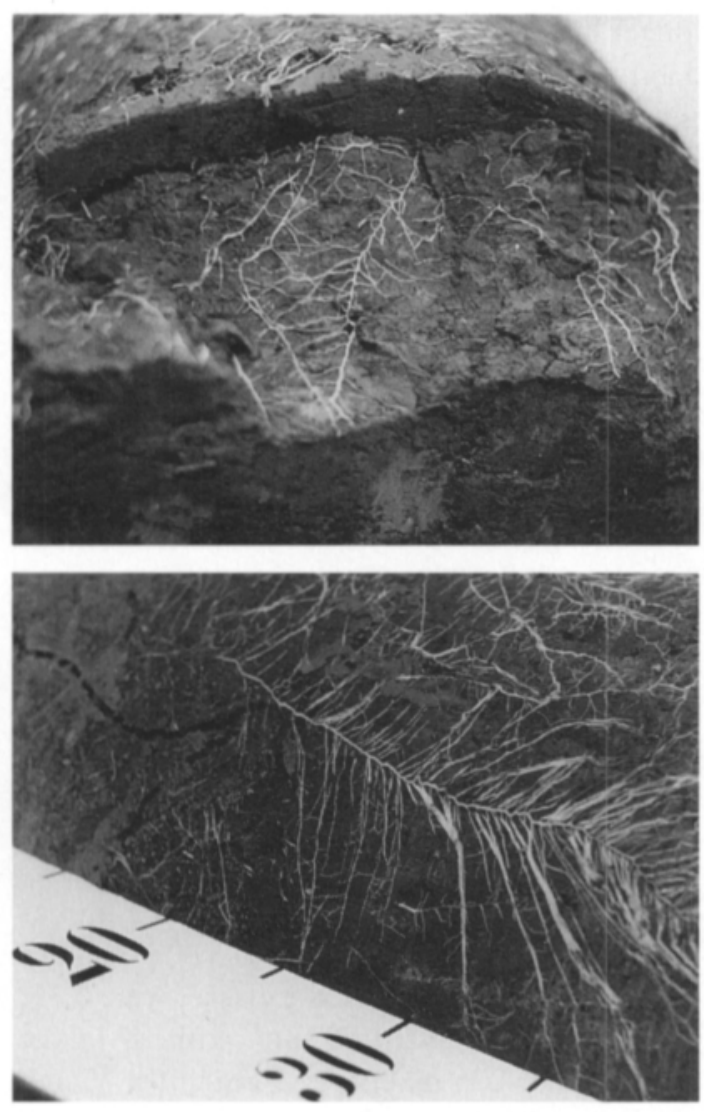

Fig. 4. Carrot fibrous root systems in 1989 inside cracks of compacted clay profile (above) and on the surface of compacted fine sand (below). Photos: Liisa Pietola.

lected separately from fine root samples were recorded at the time of sampling.

For root samples collected from fine sand in 1991 and mull in 1990-1991, dry weight data on fibrous roots was recorded in Michigan State University $\left(48 \mathrm{~h}\right.$ at $\left.70^{\circ} \mathrm{C}\right)$. After storing in ethanol (15-20\% v/v) for 2-6 months, some cellular weight may have been lost due to root tissue fixation with ethanol.

\subsubsection{Root morphology}

Fibrous root lengths and widths from samples of fine sand of 1991 and mull soil samples were determined by automated image processing of video recorded roots (Smucker 1993) in the Soil Biophysics Laboratory, Department of Crop and Soil Sciences, Michigan State University, East Lansing, USA.

\section{Video recording}

Roots were dyed with Malachite green oxalate for 24-48 hours before video recording by injecting $2-10 \mathrm{ml}$ (depending on the sample size) of $4 \%$ dye into the plastic storage bag containing $15 \%$ ethanol. Stained roots were rinsed with water on an ultra fine $(25 \mu \mathrm{m})$ nylon screen. Roots were then placed uniformly on a clear glass tray. Roots from sandy soil were recorded twice, in Procedure 1 (see next paragraph) for determination of length, and in Procedure 2 for measurement of width. Procedure 3 represents roots from mull field from which only $1 / 8$ of the sample was video recorded because of the considerable amount of non-root residues, most of which were removed from the subsamples before video recording. The results obtained by analysing subsamples were rather representative. As the mean root length and surface area per soil volume for three whole samples, containing large quantities of debris, were $0.773 \mathrm{~cm} \mathrm{~cm}^{-3}$ and $0.050 \mathrm{~cm}^{2} \mathrm{~cm}^{-3}$ the means for corresponding subsamples (1/8) were $0.764 \mathrm{~cm} \mathrm{~cm}^{-3}$ and $0.048 \mathrm{~cm}^{2}$ $\mathrm{cm}^{-3}$, respectively. This resulted in $1.1 \%$ and $4 \%$ errors in measurement of these two root parameters.

Procedure 1. The samples of fine sand (3534 $\mathrm{cm}^{3}$ ) taken from the depth of $10-50 \mathrm{~cm}$ were analysed as follows. Samples from soil surface $(0-10 \mathrm{~cm})$ were analysed only according to Procedure 3 due to the high quantity of non-root residues (over 30\%). At the depth of $10-25 \mathrm{~cm}$ the root length was so great that it was impossible to place all the roots into the large tray $(42 \mathrm{~cm} \times 37.5 \mathrm{~cm})$ without considerable overlapping. Therefore, samples were split into 2-4 subsamples. Some manual cleaning was performed while placing roots uniformly on the tray containing a thin water film ( $3 \mathrm{~mm})$ which was attained by adding $500 \mathrm{ml}$ water into the tray. 


\section{AGRICULTURAL SCIENCE IN FINLAND}

Pietola, L.: Effect of soil compactness on the growth and quality of carrot

The glass tray was illuminated from below by a translucent light table and video recorded by a computer-controlled robotic camera (Smucker 1990). Sixty images, i.e. $60 \%$ of the total area of the tray, were recorded on a VHS video tape, 19 trays per tape (117 min). For this given tray size, the images were recorded with a lens size capable of measuring the root length, but a root width less than $0.4 \mathrm{~mm}$ was not measured accurately (lens $12.5 \mathrm{~mm}$, lens extension tube $10 \mathrm{~mm}$ ). Therefore, Procedure 2 was conducted for accurate root width analysis.

Procedure 2. After recording of roots in Procedure 1, roots were subsampled from the middle of the large sample glass tray for Procedure 2 by means of a $100-\mathrm{ml}$ polyethylene syringe. Subsample size was $200 \mathrm{~cm}^{2}$ with $60 \mathrm{ml}$ solution volume. The remaining root sample was rinsed and collected on a nylon screen and dried for $48 \mathrm{~h}$ at $70^{\circ} \mathrm{C}$ for dry weight determinations. The subsample was cleaned from some short debris of which dry weight was determined in order to measure the amount of debris per root dry weight. For this given tray size $(18.5 \mathrm{~cm} \times$ $19.5 \mathrm{~cm}), 70$ images per tray (70\% of the area) were recorded, 17 trays per tape, with a lens size cabable of recording images for precise width determination of roots $\geq 0.15 \mathrm{~mm}$ in diameter (lens $12.5 \mathrm{~mm}, 4 \times$ magnification, lens extension tube $10 \mathrm{~mm}$ ). After video recording, roots were dried and dry weight was determined. Root length and surface area (see Image analysis) of a subsample were then multiplied by the ratio between root dry weights in the whole sample and the subsample.

Procedure 3. After the first cleaning by sedimentation in water, the whole sample material was placed uniformly on the big glass tray used in Procedure 1. The subsampling was performed as in Procedure 2. The rest of the material, consisting of roots and non-root residues, was dried and weighed. The subsamples were cleaned and analysed as in Procedure 2. The debris content was determined on a dry weight basis. The remaining short debris was evaluated visually by the same person. During the computer image analysis, material which was less than 4 times longer than its width was identified as non-root debris and discarded from the root data (Ferguson 1994, personal communication). Thus, this kind of non-root residue was not a source of error in the measurements of carrot root morphology.

\section{Image analysis}

The images of stained root samples on the video tapes (12 for Experiments 1-2, and 11 for Experiment 3 ) were transferred to the Vicom image analysis system in the MSU Root Image Processing Laboratory (Smucker et al. 1987, Smucker 1990, 1993). The binary image was created from the original grey scale image and digitized for measurement of root total length and individual lengths for each root width class (determined by the lengths of centre lines of original roots by using skeletonizing algorithms which contain information about root width and length) (Fig. 5). For Procedure 1, the width classes were $0.40,1.21,2.21,3.64$ and $6.12 \mathrm{~mm}$ as the resolution for each image was 100 pixels per $1 \mathrm{~cm}$. For Procedures 2-3, the classes were 0.15, $0.40,0.75,1.25$ and $1.95 \mathrm{~mm}$, with an image resolution of 276 pixels per $1 \mathrm{~cm}$ in the Vicom pipeline and parallel computer image processor. The processing time for each image was $2-2.5$ minutes in Procedure 1 and, due to smaller sample sizes, $1.5-2$ minutes in Procedures 2-3. The processing time was dependent also on the quantities of non-root residues in each sample.

The final root length of a sample was the sum of all image lengths for all width classes. For root surface area (A), the calculated projected area (sum of all image profile areas in all width classes) was multiplied by $\pi$, based on the cylindrical nature of roots and the formula:

$$
\mathrm{A}=2 \pi \mathrm{R} \mathrm{L}
$$

where $\mathrm{R}$ is root radius and $\mathrm{L}$ root length. $\mathrm{Be}$ cause root roundness varied, being higher in surface soil and lower in subsoil and in compacted fine sand (based on visual observations during video recording), this approach has limitations. The three-dimensional estimation was, howev- 
Vol. 4: 139-237.
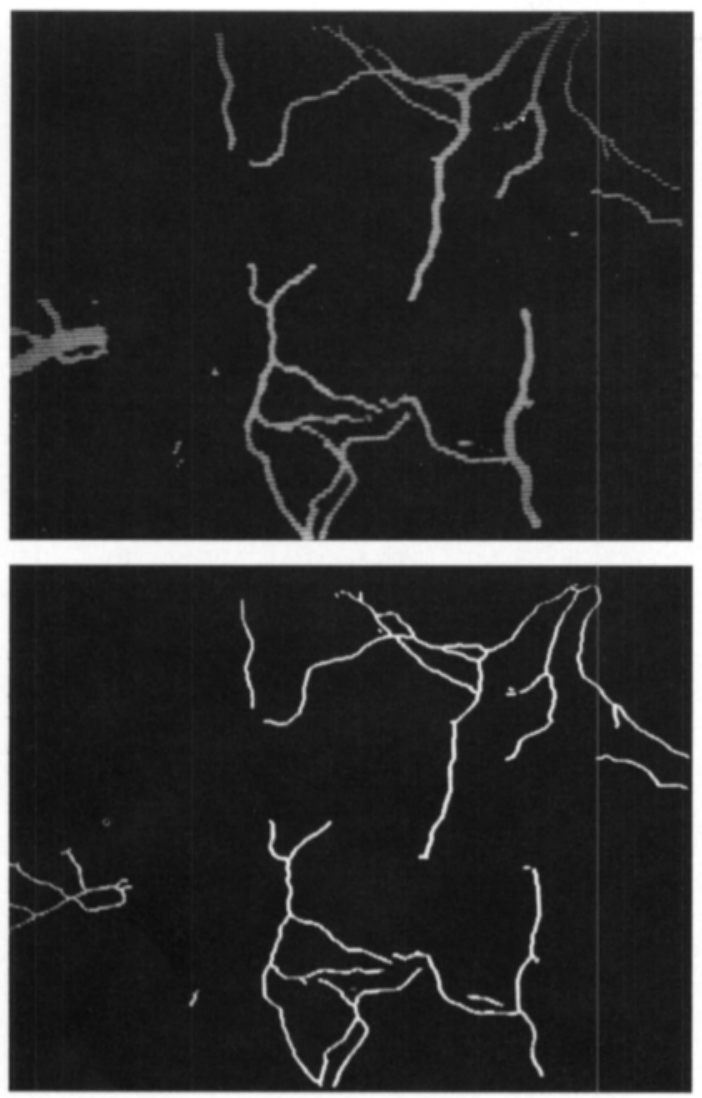

Fig. 5. Root image on computer screen during image analysis at two stages. This particular image represents roots from the loose fine sand, at $25-30 \mathrm{~cm}$ soil depth. Above: First stage of analysis where root image is created based on colour intensity of stained roots. Below: Further stage of image analysis where root images are skeletonized. Distance (no. of pixels) between this centre line and root edges (outer line of root image) determines image widths. This image represents $1 \%$ of the $360-\mathrm{cm}^{2}$ tray, from which 70 root images were recorded for a given sample. The width of roots is mostly around $0.15 \mathrm{~mm}$ and root branching uniform. To the left there is a piece of thicker root with laterals which were more abundant in compacted non-irrigated fine sand. Photos: Liisa Pietola. er, used because the cross-sectional area of roots was primarily round or at least elliptical. The two-dimensional measurement has been converted to three-dimensional estimation also in other recent studies (Kokko et al. 1993).

\subsection{Statistical analysis}

The statistical analyses were performed according to Steel and Torrie (1981) and Ranta et al. (1991). For analysis of variance, soil parameters and carrot growth in mull soil were studied according to the randomized complete-block design (4 replicates) where loosening operations and wheel traffic represented the treatments. In mineral soils, data for soil air composition (3 replicates) and carrot growth (4 replicates, except 3 replicates at the first and second sampling in clay soil) were studied according to the splitplot design where two irrigation schemes represented the main treatments. Group means were compared using Tukey's HSD (Honestly Significant Difference) test to find statistically significant $(\mathrm{P}<0.05)$ differences.

The relationships between different soil parameters and between soil properties and carrot growth were studied by the linear correlation and regression analyses. The significances of the correlation coefficient (r) at the 95, 99 and $99.9 \%$ significance levels were marked $*, * *$ and $* * *$, respectively.

In Figures 36-42, the splined lines connecting the data points were drawn by the CoPlot procedure (CoPlot Programme for Scientific Graphs 1990) based on the Bézier lines (Barnhill and Riesenfeld 1974). 
Pietola, L.: Effect of soil compactness on the growth and quality of carrot

\section{Results}

\section{I Effects of treatments on soil physical properties}

\section{I.I Soil moisture}

Clay soil was treated and sown as soon as the upper 5-cm layer was dry enough for the field operations. The fields of fine sand and mull were also established as soon as possible in order to take full advantage for carrot growth from the short growing periods in Finland. The volumetric water contents at compacting dates and the plant-available water capacity (moisture at matric potentials between $-1500 \mathrm{kPa}$ and $-10 \mathrm{kPa}$, untreated $\mathrm{B}_{3}$ subplots) of experimental soils are presented in Figure 6. These results imply high wetness in soil profiles, especially for the clay and fine sand soils, when treated, which was crucial for maximum and more uniform soil compressibility.

Results for the plant-available water recorded by gypsum blocks in untreated $B_{3}$ subplots during the growing seasons (Figs. 7-9) suggest that irrigation was needed in mineral soils twice in each experimental year, but at different times of the growing season. In 1989, drought occurred at the beginning of July, but the next year earlier in mid-June. In 1991, there was no lack of water until mid-July. On mull field, there was no need for irrigation, except for one week at the beginning of August in 1990 and 1991. The aim of irrigations, i.e. to maintain the soil moisture level above $50 \%$ of plant-available water at the depth of $15 \mathrm{~cm}$, was reached in 1990-1991 in fine sand. In 1989, the first water application was delayed, and the drought at the beginning of July affected all plots in fine sand and clay. The effect of irrigation on soil moisture was most distinct in 1990 during a long dry period when fine sand was irrigated.

According to the soil moisture measurements before carrot growth in May 1991, loose soil
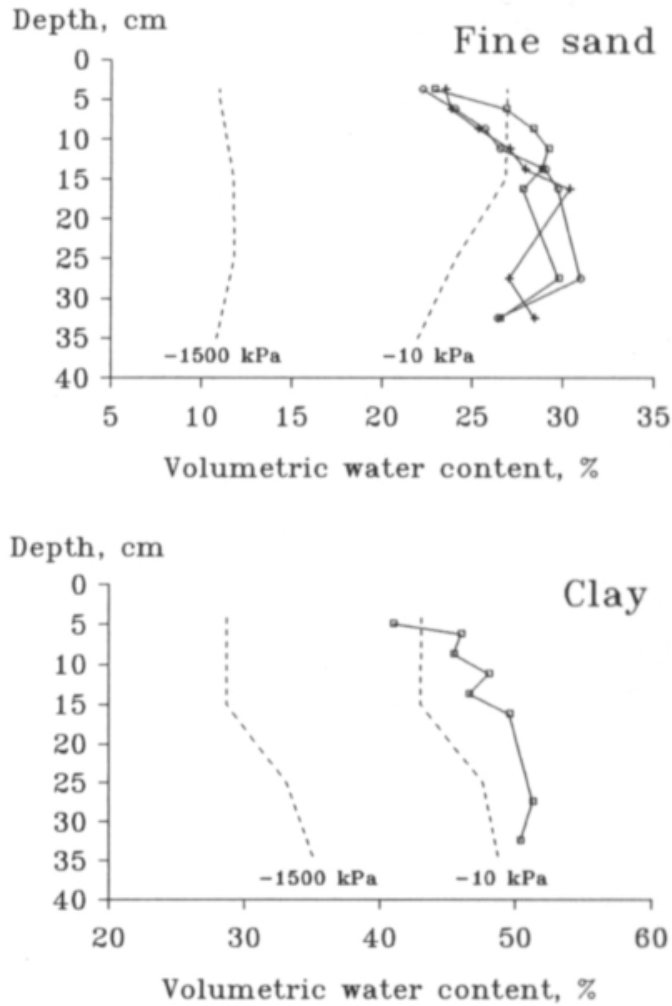

Depth, cm

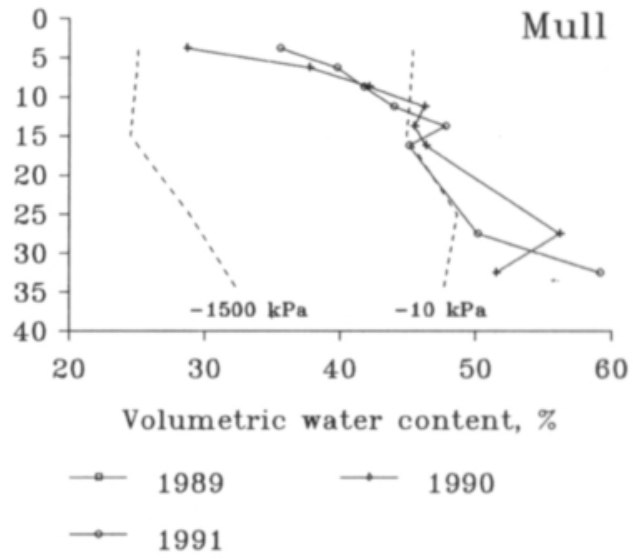

Fig. 6. Volumetric soil water contents of experimental sites at different soil depths (in untreated $\mathrm{B}_{3}$ plots) at compacting dates in 1989-1991. Plant-available water capacity between broken lines (matric potential from $-1500 \mathrm{kPa}$ to $-10 \mathrm{kPa})$. 
Vol. 4: 139-237.

Available soil moisture, \%

Precipitation/

Irrigation, $\mathrm{mm}$
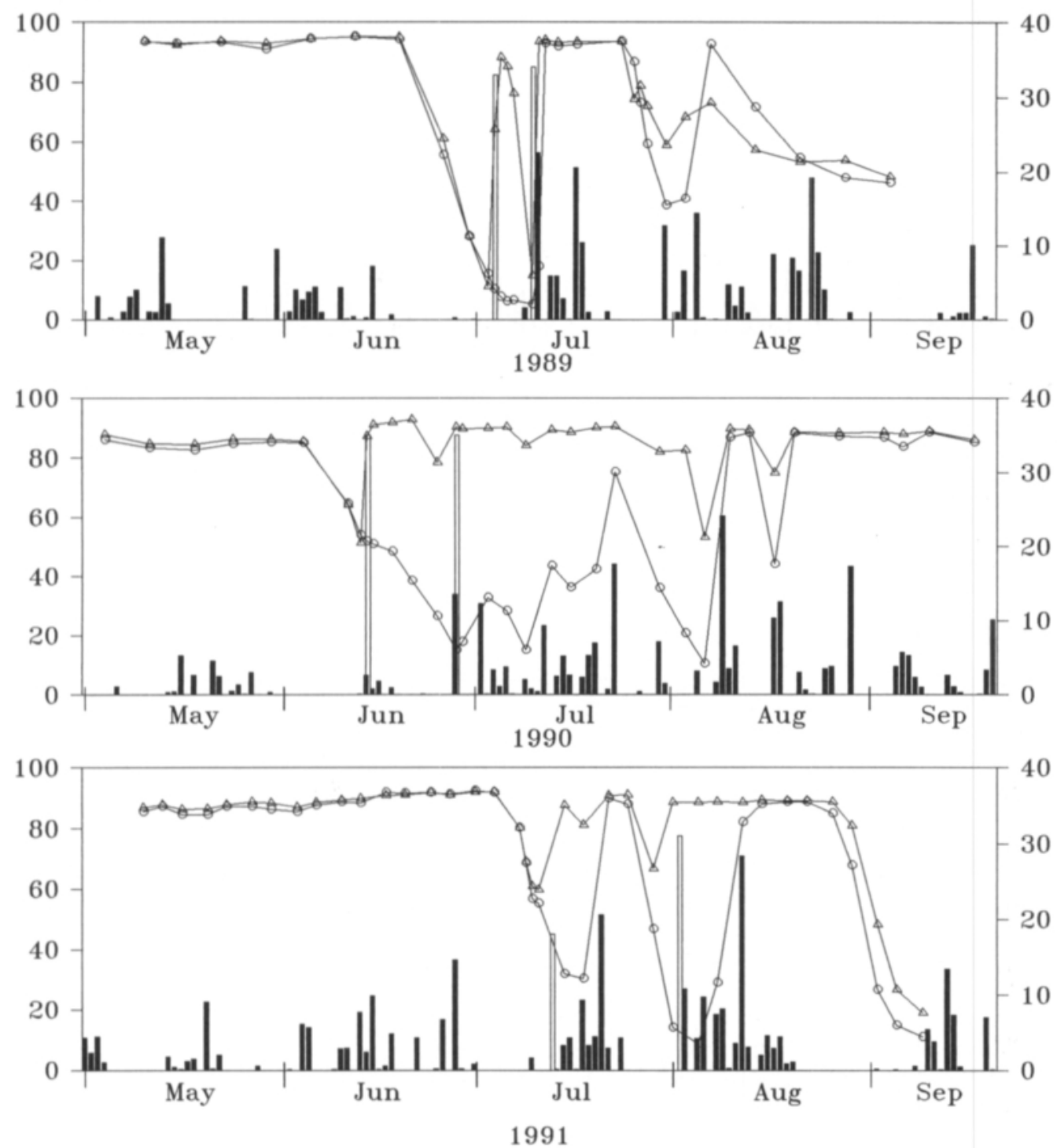

Fig. 7. Moisture status by gypsum block recordings in fine sand field at the depth of $15 \mathrm{~cm}$ in non-compacted $\mathrm{B}_{3}$ treatment in $A_{0}$ plots without irrigation (circles) and in $A_{1}$ plots with irrigation (triangles) in 1989-1991. White columns indicate irrigation and black columns precipitation.

profiles were drier than compacted soil, but only if moisture was calculated on volume basis. Measurements from soil core samples indicated that the volumetric water contents of both fine sand and mull were higher than that of the more compacted soil, when averages of five samples (at $7.5-17.5 \mathrm{~cm}, 2.5-\mathrm{cm}$ intervals) were compared (Table 4). 
Pietola, L.: Effect of soil compactness on the growth and quality of carrot

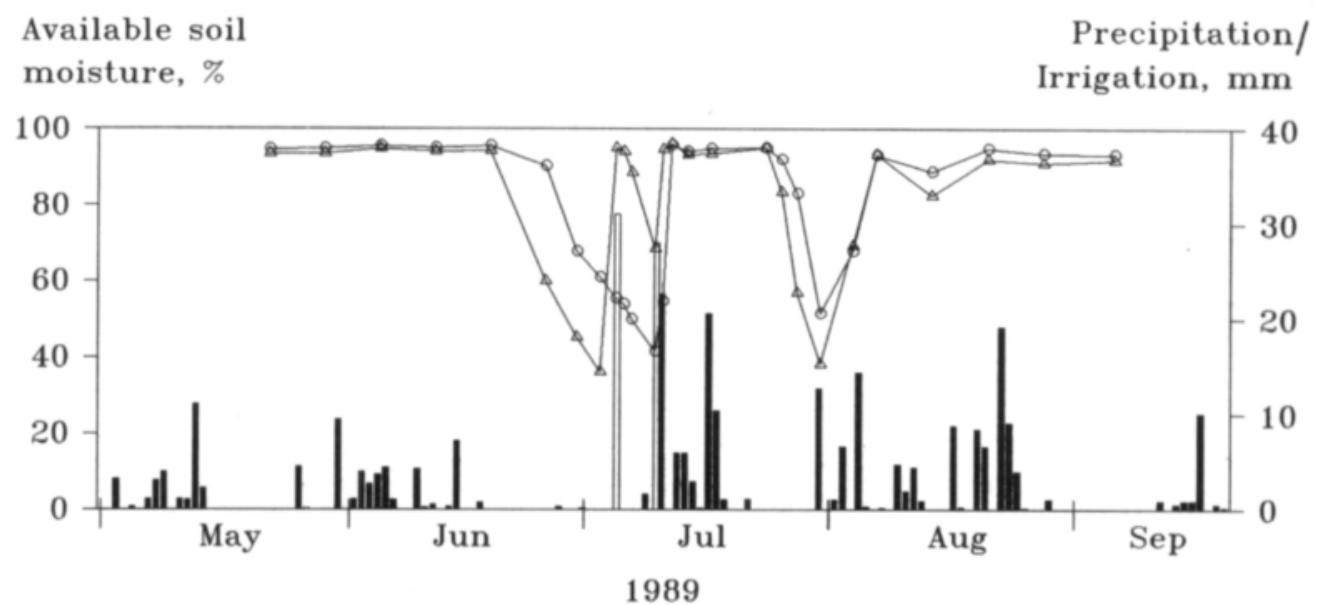

Fig. 8. Moisture status by gypsum block recordings in clay field at the depth of $15 \mathrm{~cm}$ in non-compacted $\mathrm{B}_{3}$ treatment, in non-irrigated $\mathrm{A}_{0}$ plots (circles) and in irrigated $\mathrm{A}_{1}$ plots (triangles) in 1989. White columns indicate irrigation and black columns precipitation.

Available soil

moisture, \%

Precipitation, mm
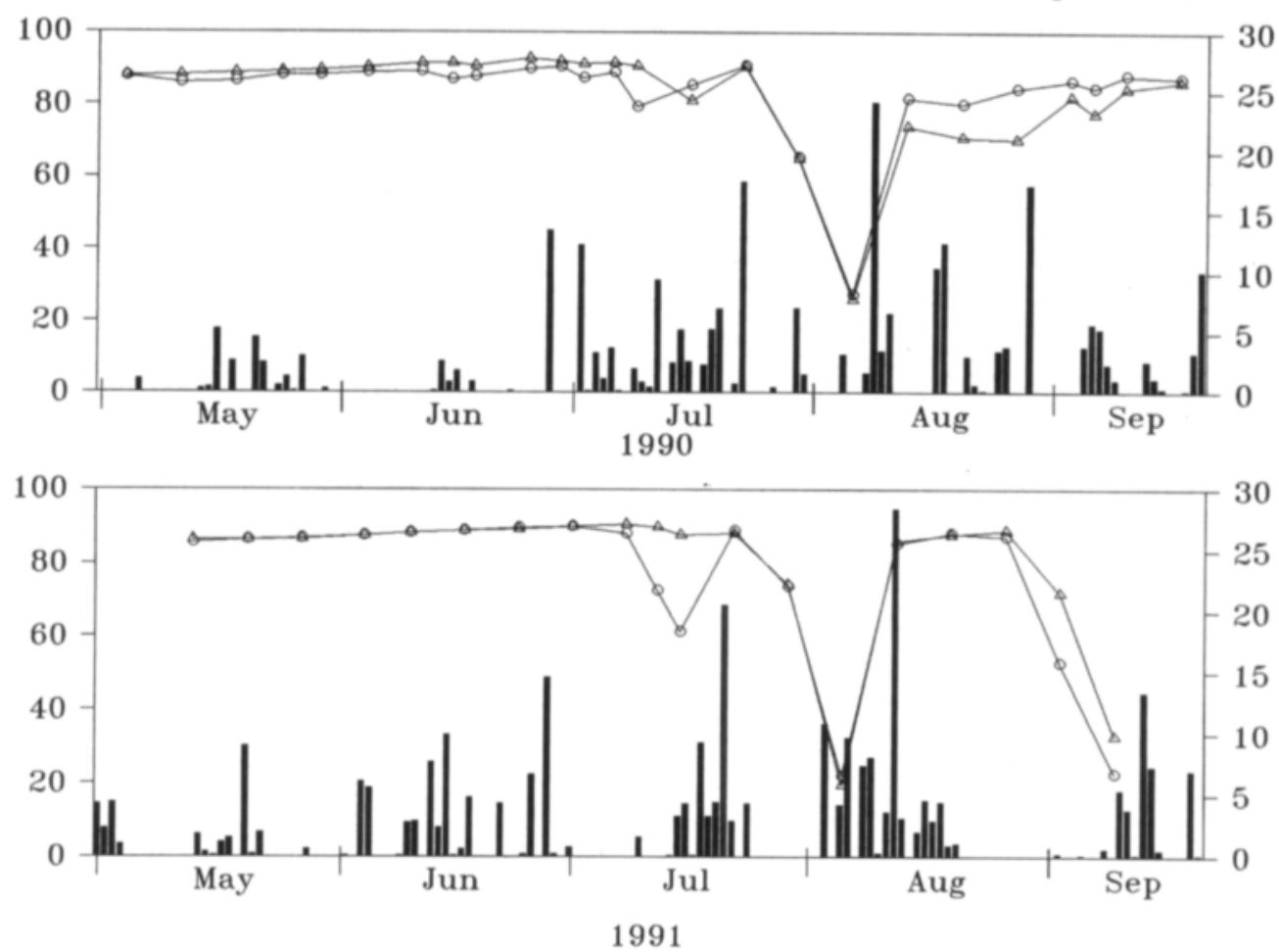

Fig. 9. Moisture status by gypsum block recordings in mull field at the depth of $15 \mathrm{~cm}$ (circles) and $30 \mathrm{~cm}$ (triangles) in noncompacted $B_{3}$ treatment in 1990-1991. Black columns indicate precipitation. 


\section{AGRICULTURAL SCIENCE IN FINLAND}

Vol. 4: 139-237.

Table 4. Water content (\%) of loosened and compacted soils at the depth of 7.5-17.5 cm during plant emergence in May 1991. $\theta=$ volumetric water content, $w=$ gravimetric water content.

\begin{tabular}{lcccc}
\hline Soil & $\begin{array}{c}\text { Soil } \\
\text { loosening }\end{array}$ & \multicolumn{2}{l}{ Tractor wheel passes (n) } & $\mathrm{HSD}_{0.05}$ \\
\cline { 3 - 4 } & 0 & 1 & 3 \\
\hline
\end{tabular}

Fine sand

\begin{tabular}{lccccc}
$\theta$ & 23.5 & 27.6 & 30.3 & 31.1 & 2.7 \\
$w$ & 20.8 & 21.9 & 22.0 & 21.1 & n.s. ${ }^{2)}$ \\
Mull & & & & & \\
$\theta$ & 42.1 & 44.7 & 50.8 & 53.8 & 3.5 \\
$w$ & 73.2 & 73.3 & 72.8 & 71.9 & n.s. \\
\hline
\end{tabular}

${ }^{1)}$ rotary harrowing

${ }^{2)}$ n.s. = not significant

During vigorous plant growth, the gypsum block values of all other subplots did not differ significantly from those of $\mathrm{B}_{3}$ plots in fine sand. In July-August, both in clay $(\mathrm{P}<0.05$, at $15 \mathrm{~cm})$ and mull fields $(\mathrm{P}<0.10$ in August 1991, at 15 and $30 \mathrm{~cm}$ ), the plant available water remained at the highest level in $\mathrm{B}_{3}$ treatment (Fig. 10). This could indicate more efficient water uptake under compacted soil conditions and lower water supply in loose soil, which is shown by positive correlations between soil dry bulk density and soil volumetric water content $(r=0.49 * * *$ for fine sand, $r=0.90^{* * *}$ for mull, based on soil $50-\mathrm{cm}^{3}$ corings at $7.5-17.5 \mathrm{~cm}$ in July 1990 and August 1991, respectively).

\section{I.2 Soil dry bulk density}

\section{Gravimetric analysis}

The role of soil mechanical treatments on gravimetric soil bulk densities of all experimental soils at four different soil depths is shown in Figure 11. These dry bulk densities are based on samples of $200 \mathrm{~cm}^{3}$, collected in September 1990 (clay 1989) for determination of soil moisture at field capacity (see 2.5.5). As the clay soil dry bulk density was measured only by this $200-\mathrm{cm}^{-3}$
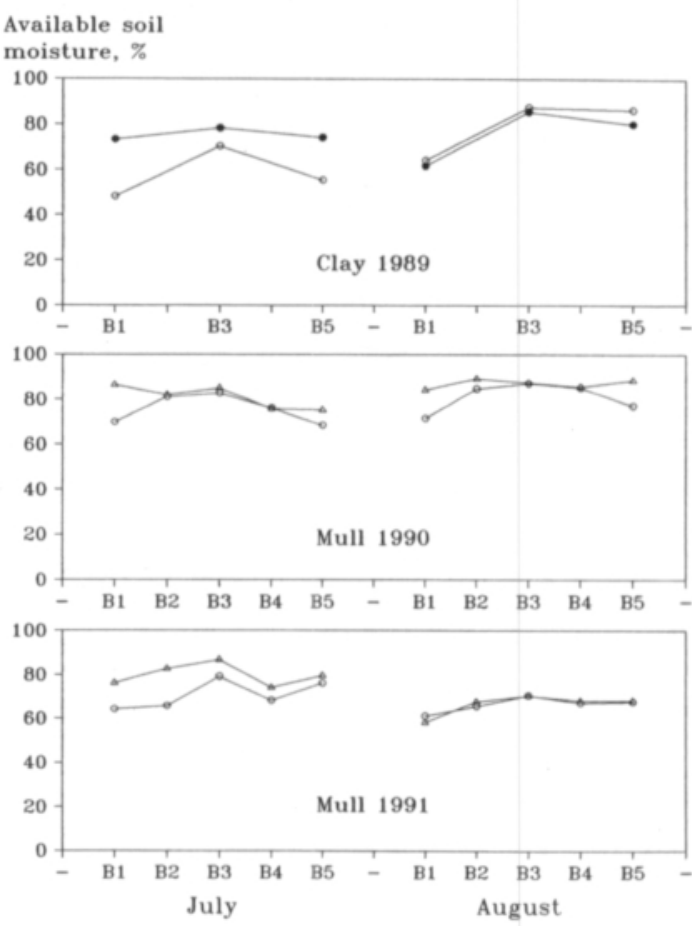

Fig. 10. Plant-available soil water (monthly averages of gypsum block recordings) as affected by mechanical treatments $\left(B_{1}-B_{5}\right)$ in clay and mull at the depths of $15 \mathrm{~cm}$ (circle) and $30 \mathrm{~cm}$ (triangle). White circles or triangles indicate non-irrigated plots $\left(\mathrm{A}_{0}\right)$ and black circles irrigated plots $\left(A_{1}\right) \cdot B_{1}=$ soil loosening by ridge preparation, $B_{2}=$ soil loosening by rotary harrowing, $\mathrm{B}_{3}=$ untreated, $\mathrm{B}_{4}=$ one pass of the tractor wheel, $\mathrm{B}_{5}=$ three passes of the tractor wheel.

HSD $_{0.05}$ for significant differences:

in July $11 \%$ (at the same A level 16\%), in August $15 \%(21 \%)$

sampling, the results in Figure 11 are given for comparison between soil types. In all three soils, the mechanical treatments did not affect the dry bulk density below the depth of $27.5 \mathrm{~cm}$. Above this depth, soil dry bulk density increased from treatment $\mathrm{B}_{1}$ to treatment $\mathrm{B}_{5}$. In $\mathrm{B}_{2}$ treatment, at the depth of $12.5-17.5 \mathrm{~cm}$, the dry bulk density of fine sand was lower than in $\mathrm{B}_{1}$ treatment. In clay soil, only one sample was taken per subplot which explains the great variation. Thus, differences between treatments at the $95 \%$ significance level were found only in the surface layer (2.5$7.5 \mathrm{~cm}$ ), even though the increase of dry bulk density by soil compaction $\left(\mathrm{B}_{5}\right)$ was as much as 


\section{AGRICULTURAL SCIENCE IN FINLAND}

Pietola, L.: Effect of soil compactness on the growth and quality of carrot

Depth, cm

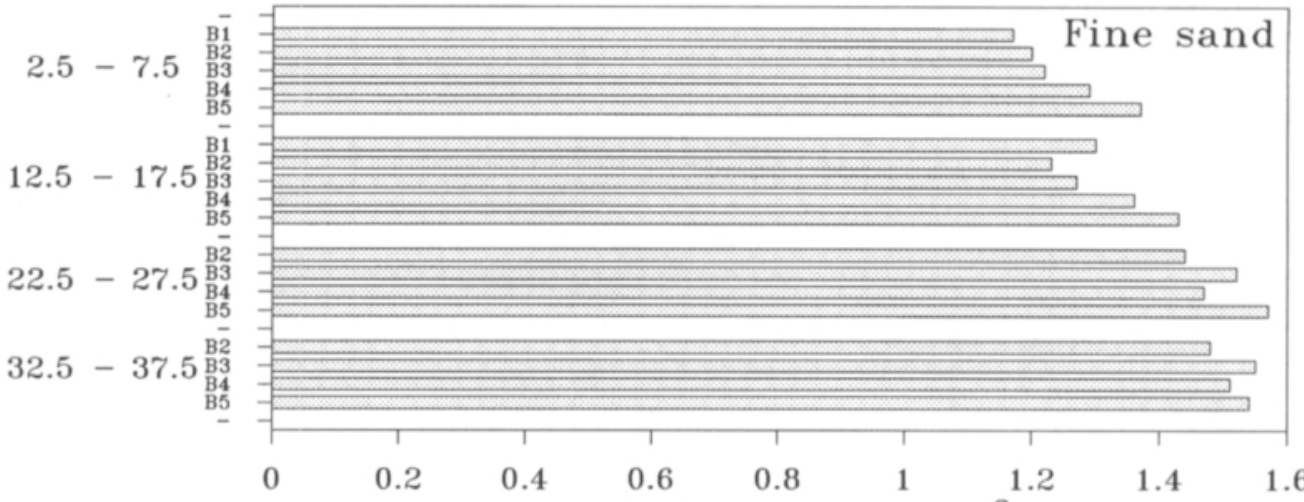

Depth, cm Dry bulk density, $\mathrm{g} \mathrm{cm}^{-3}$

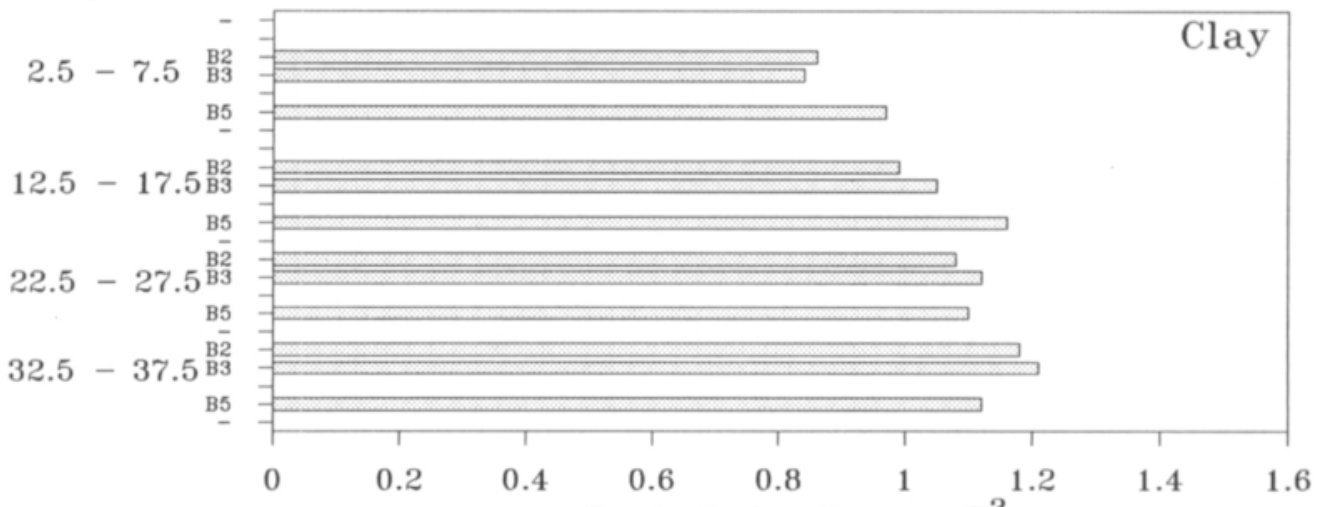

Depth, cm

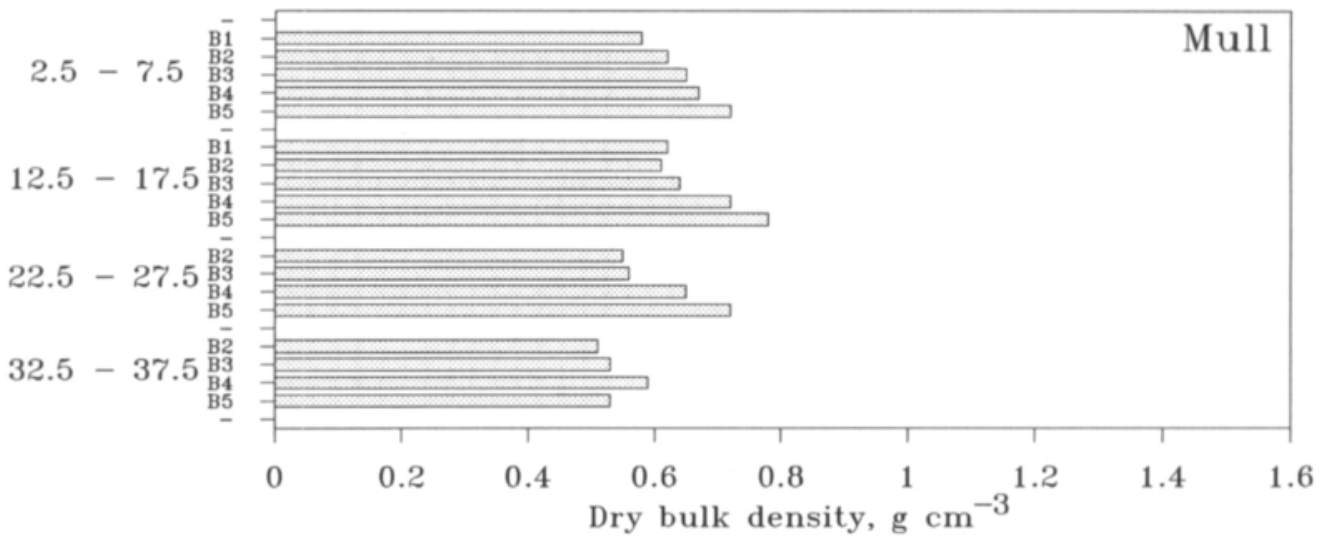

Fig. 11. Soil dry bulk density at four depths as affected by soil depth and soil mechanical treatments $\left(\mathrm{B}_{1}-\mathrm{B}_{5}\right)$ based on dry weights of core samples $\left(200 \mathrm{~cm}^{3}\right.$ ) taken in September 1990 (for clay 1989). $\mathrm{B}_{1}=$ soil loosening by ridge preparation, $\mathrm{B}_{2}=$ soil loosening by rotary harrowing, $\mathrm{B}_{3}=$ untreated, $\mathrm{B}_{4}=$ one pass of the tractor wheel, $\mathrm{B}_{5}=$ three passes of the tractor wheel.

HSD $_{0 \text { os }}$ for significant differences:

Fine sand: $0.06 \mathrm{~g} \mathrm{~cm}^{-3}$ at $2.5-7.5 \mathrm{~cm}, 0.09 \mathrm{~g} \mathrm{~cm}^{-3}$ at $12.5-27.5 \mathrm{~cm}$

Clay: $0.13 \mathrm{~g} \mathrm{~cm}^{-3}$ at $2.5-7.5 \mathrm{~cm}$

Mull: $0.05 \mathrm{~g} \mathrm{~cm}^{-3}$ at $2.5-7.5 \mathrm{~cm}, 0.06 \mathrm{~g} \mathrm{~cm}^{-3}$ at $12.5-17.5 \mathrm{~cm}, 0.12 \mathrm{~g} \mathrm{~cm}^{-3}$ at $22.5-27.5 \mathrm{~cm}$ 
Vol. 4: 139-237.

Table 5. Dry bulk density $\left(\mathrm{g} \mathrm{cm}^{-3}\right)$ of loosened and compacted soils based on gravimetric core analyses in July - August 1990.

\begin{tabular}{|c|c|c|c|c|c|c|}
\hline \multirow{2}{*}{$\begin{array}{l}\text { Soil } \\
\text { depth, cm }\end{array}$} & \multicolumn{2}{|c|}{ Soil loosening1) } & \multicolumn{3}{|c|}{ Tractor wheel passes (n) } & \multirow[t]{2}{*}{$\mathrm{HSD}_{0.0}$} \\
\hline & 1 & 2 & 0 & 1 & 3 & \\
\hline \multicolumn{7}{|l|}{ Fine sand } \\
\hline $2.5-7.5$ & 1.13 & 1.23 & 1.30 & 1.28 & 1.33 & 0.14 \\
\hline $7.5-12.5$ & 1.23 & 1.20 & 1.28 & 1.31 & 1.46 & 0.18 \\
\hline $12.5-17.5$ & 1.33 & 1.24 & 1.31 & 1.34 & 1.49 & 0.16 \\
\hline $25.0-30.0$ & n.d. ${ }^{2)}$ & 1.49 & 1.59 & 1.53 & 1.49 & n.s. ${ }^{3)}$ \\
\hline $30.0-35.0$ & n.d. & 1.56 & 1.56 & 1.58 & 1.56 & n.s. \\
\hline \multicolumn{7}{|l|}{ Mull } \\
\hline $2.5-7.5$ & 0.62 & 0.61 & 0.61 & 0.64 & 0.68 & n.s. \\
\hline $7.5-12.5$ & 0.65 & 0.62 & 0.66 & 0.71 & 0.75 & 0.07 \\
\hline $12.5-17.5$ & 0.66 & 0.62 & 0.66 & 0.73 & 0.76 & 0.13 \\
\hline $25.0-30.0$ & n.d. & 0.58 & 0.62 & 0.72 & 0.61 & 0.16 \\
\hline $30.0-35.0$ & n.d. & 0.47 & 0.43 & 0.61 & 0.51 & n.s. \\
\hline
\end{tabular}

1) 1 = ridge preparation, 2 = rotary harrowing

${ }^{2)}$ n.d. = not determined

${ }^{3)}$ n.s. = not significant

Table 6. Dry bulk density $\left(\mathrm{g} \mathrm{cm}^{-3}\right)$ of loosened and compacted soils based on $\gamma$-ray transmission in July August 1990.

\begin{tabular}{lccccc}
\hline \multirow{2}{*}{$\begin{array}{l}\text { Soil } \\
\text { depth, cm }\end{array}$} & $\begin{array}{c}\text { Soil } \\
\text { loosening1) }\end{array}$ & \multicolumn{3}{c}{ Tractor wheel passes (n) } & \\
\cline { 3 - 4 } & & 0 & 1 & HSD $_{0.05}$ \\
\hline Fine sand & & & & & \\
$2.5-7.5$ & 1.30 & 1.33 & 1.37 & 1.47 & 0.07 \\
$7.5-12.5$ & 1.25 & 1.33 & 1.44 & 1.54 & 0.07 \\
$12.5-17.5$ & 1.28 & 1.37 & 1.45 & 1.57 & 0.13 \\
$25.0-30.0$ & 1.58 & 1.68 & 1.60 & 1.63 & n.s. \\
$30.0-35.0$ & 1.69 & 1.69 & 1.66 & 1.66 & n.s. \\
Mull & & & & & \\
$2.5-7.5$ & 0.65 & 0.67 & 0.71 & 0.77 & 0.07 \\
$7.5-12.5$ & 0.64 & 0.69 & 0.77 & 0.79 & 0.10 \\
$12.5-17.5$ & 0.63 & 0.66 & 0.74 & 0.80 & 0.10 \\
$25.0-30.0$ & 0.62 & 0.61 & 0.71 & 0.70 & n.s. \\
$30.0-35.0$ & 0.48 & 0.50 & 0.72 & 0.68 & n.s. \\
\hline
\end{tabular}

1) rotary harrowing

${ }^{2)}$ n.s. = not significant

$0.2 \mathrm{~g} \mathrm{~cm}^{3}$ at the depth of $12.5-17.5 \mathrm{~cm}$ as compared with $\mathrm{B}_{2}$ treatment.

The results were the same at the $50-\mathrm{cm}^{3}$ coring as the impact of mechanical treatments on dry bulk density was recorded in the plough layer
(Table 5). The loosest soil was determined in $\mathrm{B}_{2}$ treatment and the most compacted soil by three tractor wheelings $\left(\mathrm{B}_{5}\right)$. Based on this sampling, the effect of soil compaction went deeper in mull soil than in fine sand. 
Pietola, L.: Effect of soil compactness on the growth and quality of carrot
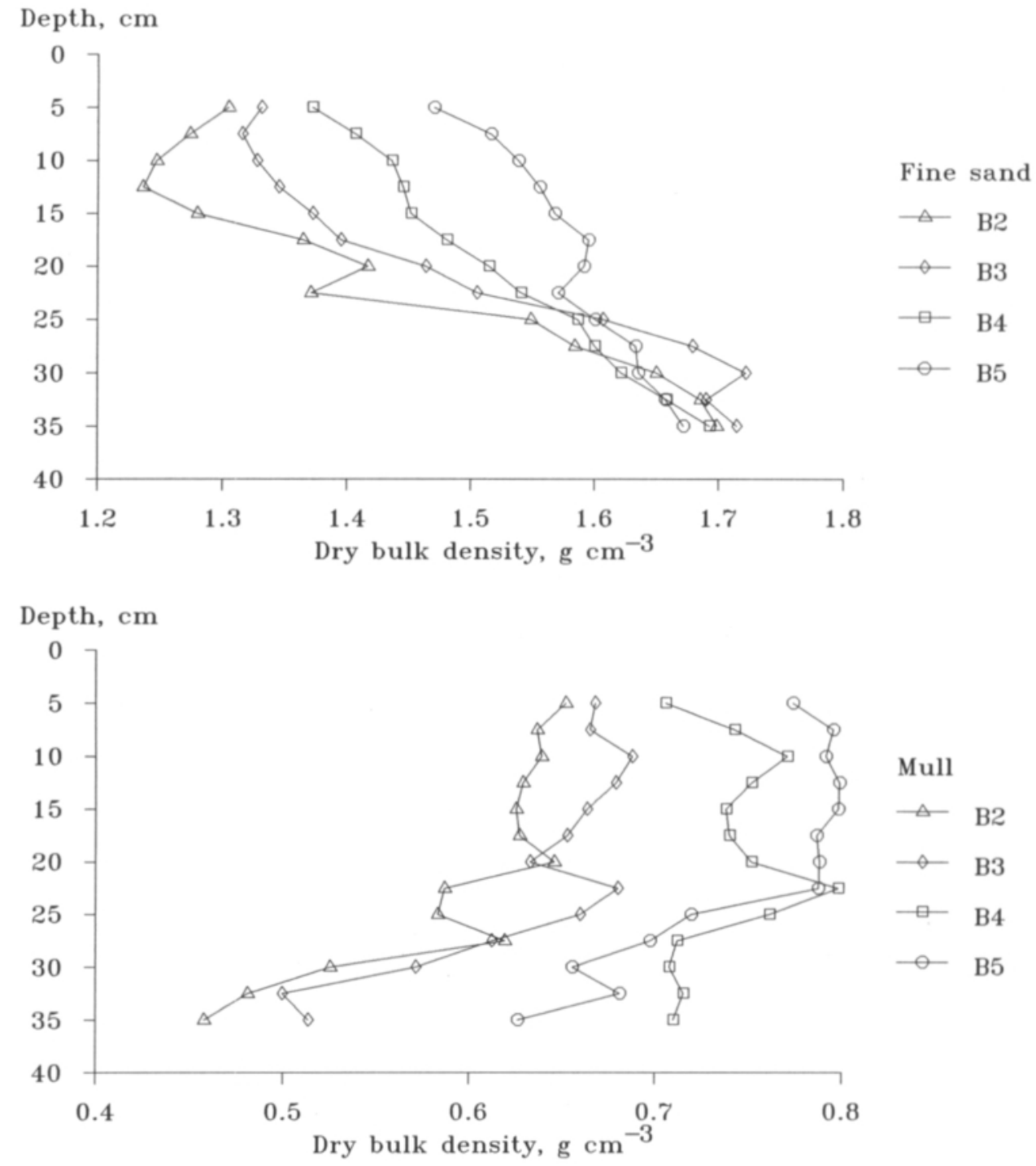

Fig. 12. Soil dry bulk density as affected by soil depth and soil mechanical treatments $\left(\mathrm{B}_{2}-\mathrm{B}_{5}\right)$ based on $\gamma$-ray transmission in July-August $1990 . B_{2}=$ soil loosening by rotary harrowing, $B_{3}=$ untreated $B_{4}=$ one pass of the tractor wheel, $B_{5}=$ three passes of the tractor wheel.

$\mathrm{HSD}_{\text {oos }}$ and average dry bulk densities at 5-cm intervals in Table 6.

\section{Gamma ray transmission}

The dry bulk density measured by gamma ray transmission differed by soil mechanical treat- ments as is shown by the core methods above. According to the measurements at $2.5-\mathrm{cm}$ intervals, the mechanical treatments affected dry bulk density to a depth of $25 \mathrm{~cm}$ in fine sand, but deep- 
Vol. 4: 139-237.

er in mull (Fig. 12). Table 6 shows these dry bulk densities based on gamma ray transmission from the same sites which represented core sampling in Table 5 .

\section{Gravimetric analysis vs. gamma ray transmission}

Tables 5 and 6 indicate that the gravimetric core samples of $2 \times 50 \mathrm{~cm}^{3}$ gave the lowest bulk densities for a given treatment at a given depth. In sandy soil, dry bulk densities by gamma ray transmission were in loose plots on average $0.05 \mathrm{~g} \mathrm{~cm}^{-3}$ higher than after the core analysis. In compacted soil, the difference was $0.1 \mathrm{~g} \mathrm{~cm}^{-3}$. Similarly, in mull the differences were 0.03 and $0.05 \mathrm{~g} \mathrm{~cm}^{-3}$, respectively.

In mull, the relationship between dry bulk densities (at $2.5-17.5 \mathrm{~cm}$ ) by core sampling and gamma ray transmission was a little closer $\left(\mathrm{r}=0.73^{* * *}\right)$ than in fine sand $\left(\mathrm{r}=0.69^{* * *}\right)$. There was a negative relationship between dry bulk density by gamma-ray transmission and soil gravimetric water content (fine sand $\mathrm{r}=$ $-0.56 * * *$, mull $\left.\mathrm{r}=-0.38^{* * *}\right)$. For both soil types, the coefficient of determination $\left(R^{2}\right)$ was slightly higher when soil gravimetric water content $(w, \%)$ was included in the regression analysis. For sandy soil, the regression equation $(\mathrm{P}<0.001)$ for dry bulk density measured by the gamma source $\left(\rho_{\mathrm{b}, \mathrm{ga}}, \mathrm{g} \mathrm{cm}^{-3}\right)$ was:

$$
\rho_{\mathrm{b}, \mathrm{ga}}=1.13+0.49 \rho_{\mathrm{b}, \mathrm{gg}}-0.02 w \quad\left(\mathrm{R}^{2}=0.55\right)
$$

where $\rho_{b, g r}$ is the reference dry bulk density by the gravimetric method. For mull, the corresponding equation $(\mathrm{P}<0.01)$ was

$$
\rho_{\text {b,ga }}=0.48+0.66 \rho_{\text {b,gr }}-0.03 w \quad\left(\mathrm{R}^{2}=0.59\right)
$$

According to Stengel et al. (1986), the dry bulk densities analysed from the irradiated area by core samples of $4959 \mathrm{~cm}^{3}\left(\rho_{b, g r}\right)$ were very closely correlated with the dry bulk densities $\left(\rho_{\mathrm{b}, \mathrm{ga}}\right)$ given by gamma sounder $(\mathrm{n}=28)$ :

$$
\rho_{b, g a}=0.966 \rho_{b, g r}-0.003 \quad\left(R^{2}=0.94\right)
$$

Without elimination of the effect of soil moisture, the coefficients of determination $\left(\mathrm{R}^{2}\right)$ were 0.47 and 0.53 for fine sand and mull, respectively. These low coefficients of determination of 96 cases imply a heterogeneity of the soil, as the method of gamma ray transmission is compared with two small-core samples of $50 \mathrm{~cm}^{-3}$ located in the middle of the $30 \mathrm{~cm}$ wide irradiated area at $2.5-\mathrm{cm}$ depth intervals. In order to have absolute values for soil dry bulk density by a gamma sounder, soil moisture should be analysed very accurately. For example, if the gravimetric soil water content of fine sand were $25 \%$, but had been measured as $20 \%$, the correct dry bulk density $1.25 \mathrm{~g} \mathrm{~cm}^{-3}$ would have been $1.31 \mathrm{~g} \mathrm{~cm}^{-3}$, assuming the bulk density without moisture calibration to be $1.60 \mathrm{~g} \mathrm{~cm}^{-3}$ (see Eq. 4 , 2.5.3). These data suggest that increasing soil water contents may obliterate the accuracy of evaluating soil bulk density by gamma ray transmission.

\section{I.3 Degree of surface soil compactness}

The dry bulk densities of very compact plough layers at the reference state $\left(\rho_{\mathrm{d}, \mathrm{p}}\right.$, Håkansson 1990) were as follows (volumetric water contents after compression in parentheses):

$\begin{array}{ll}\text { Fine sand } & 1.589 \\ \text { Clay } & 1.156 \\ \text { Mull } & 0.803\end{array}$

The different degrees of soil compactness, where dry bulk densities in each treatment were calculated on the basis of both the core method and gamma ray transmission, confirmed that soil compactness increased by one tractor wheeling relatively more on mull than on fine sand (Fig. 13). In addition, these results exemplify the higher correlation between two methods of dry bulk density measurements in organic soil than in sandy soil, particularly in loose soil profiles.

Compactness of the plough layer of clay soil, where no $50-\mathrm{cm}^{3}$ coring or gamma ray analysis 
Pietola, L.: Effect of soil compactness on the growth and quality of carrot

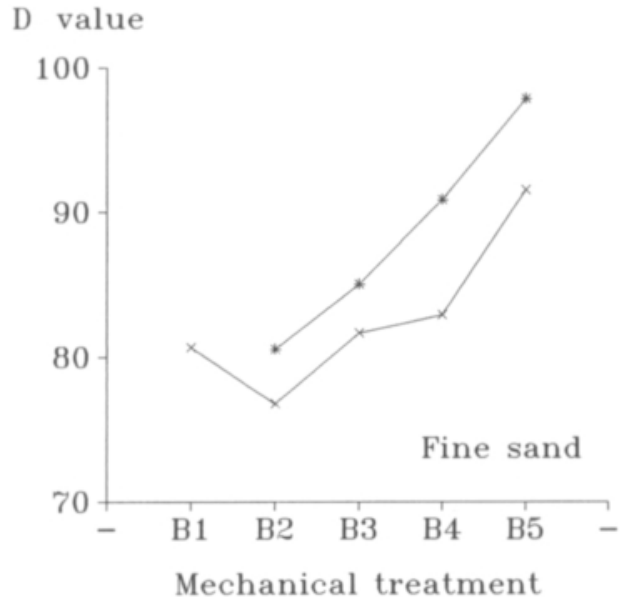

$\approx$ Gravimetric analysis
D value

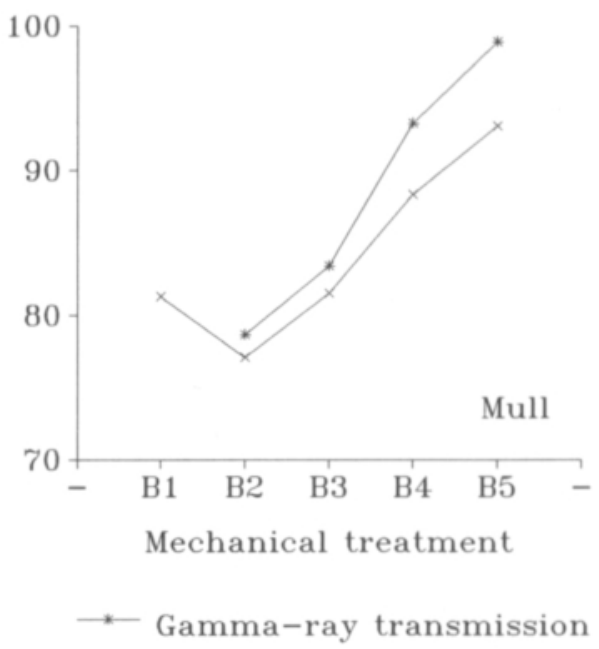

Fig. 13. Soil compactness according to the method of Håkansson (1992), D value = relation between actual and maximal (at $200 \mathrm{kPa})$ soil bulk density $(\%)$ at the depth of $7.5-17.5 \mathrm{~cm}$ as affected by soil mechanical treatments $\left(\mathrm{B}_{1}-\mathrm{B}_{5}\right) . \mathrm{B}_{1}=$ soil loosening by ridge preparation, $\mathrm{B}_{2}=$ soil loosening by rotary harrowing, $\mathrm{B}_{3}=$ untreated, $\mathrm{B}_{4}=$ one pass of the tractor wheel, $\mathrm{B}_{5}=$ three passes of the tractor wheel.

was carried out, can be compared with that of other soils by means of dry bulk densities based on core samples of $200 \mathrm{~cm}^{3}$ from the depths of $2.5-7.5 \mathrm{~cm}$ and $12.5-17.5 \mathrm{~cm}$ (see 2.5.5). The degrees of clay soil compactness averaged (D) $80.1,81.6$ and 92.0 in treatments $\mathrm{B}_{2}, \mathrm{~B}_{3}$ and $\mathrm{B}_{5}$, respectively $\left(\mathrm{HSD}_{0.05}=8.2\right)$. The respective values for fine sand were $76.5,78.3$ and 88.0 $\left(\mathrm{HSD}_{0.05}=5.5\right)$, and for mull 76.1, 80.5 and 92.5 $\left(\mathrm{HSD}_{0.05}=9.1\right)$. These results showed that the $0-20 \mathrm{~cm}$ depths of soils are compressed more as the clay content increases (Table 1, p. 151). These degrees of compactness are, however, lower than in Figure 13 for fine sand and mull, because the compact zone at the depth of 7.5$12.5 \mathrm{~cm}$ was not measured by $200-\mathrm{cm}^{3}$ coring.

\section{I.4 Penetrometer resistance}

Under dry soil conditions, soil compaction affected soil penetrometer resistance more than loosening treatments as compared with $\mathrm{B}_{3}$ plots in all experimental soils (Fig. 14). The maximum resistances in $\mathrm{B}_{5}$ treatment were $3.25 \mathrm{MPa}$ (at $30 \mathrm{~cm}$ ), $3.25 \mathrm{MPa}$ (at $10 \mathrm{~cm}$ and $30 \mathrm{~cm}$ ) and $2 \mathrm{MPa}($ at $30 \mathrm{~cm}$ ) in fine sand, clay and mull, respectively. In Figure 14, the results of fine sand and clay soils represent the date of 5 July 1989 , and mull soil 17 July 1990. Based on averages of the same measurements from the depths of $7.0-17.5 \mathrm{~cm}$ and $24.5-35.0 \mathrm{~cm}$, the penetrometer resistance decreased by soil loosening and increased by soil compaction in fine sand also at the depth of $24.5-35.0 \mathrm{~cm}$, while the clay subsoil remained unaffected (Table 7).

Based on the measurements in 1990-1991, soil loosening decreased the penetrometer resistance to the depth of $35 \mathrm{~cm}$ in both fine sand and mull. Also irrigation decreased the resistance in fine sand to this depth (Table 8). According to these results of penetrometer resistance in different moisture conditions of fine sand (Fig. 15) and mull (Fig. 16), soil moisture had a greater effect on penetrometer resistance in compacted 


\section{AGRICULTURAL SCIENCE IN FINLAND}

Vol. 4: 139-237.

Depth, cm

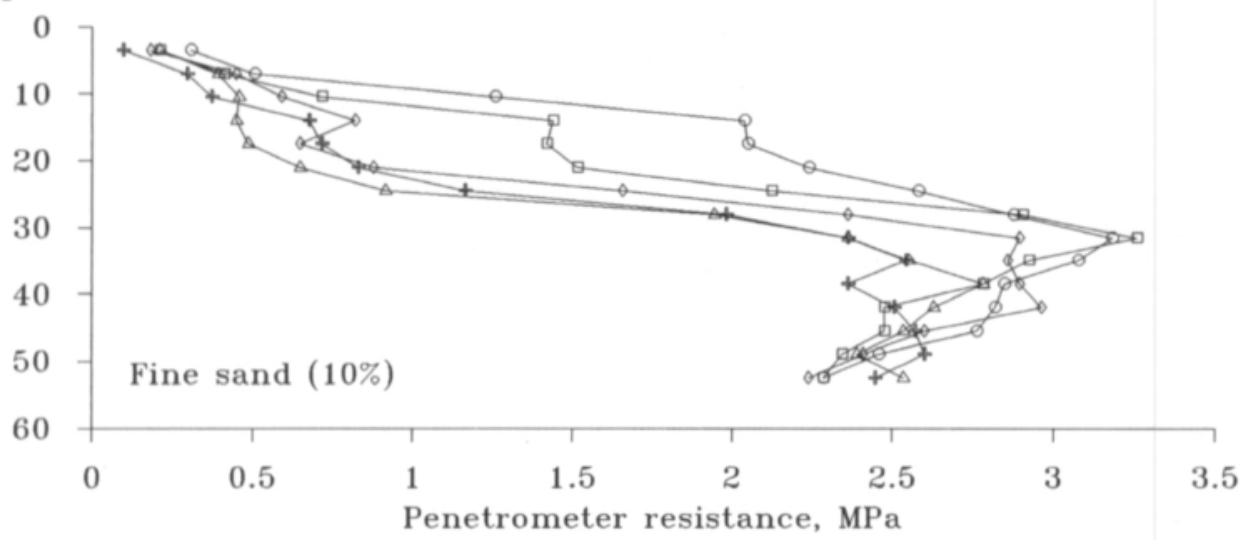

Depth, cm

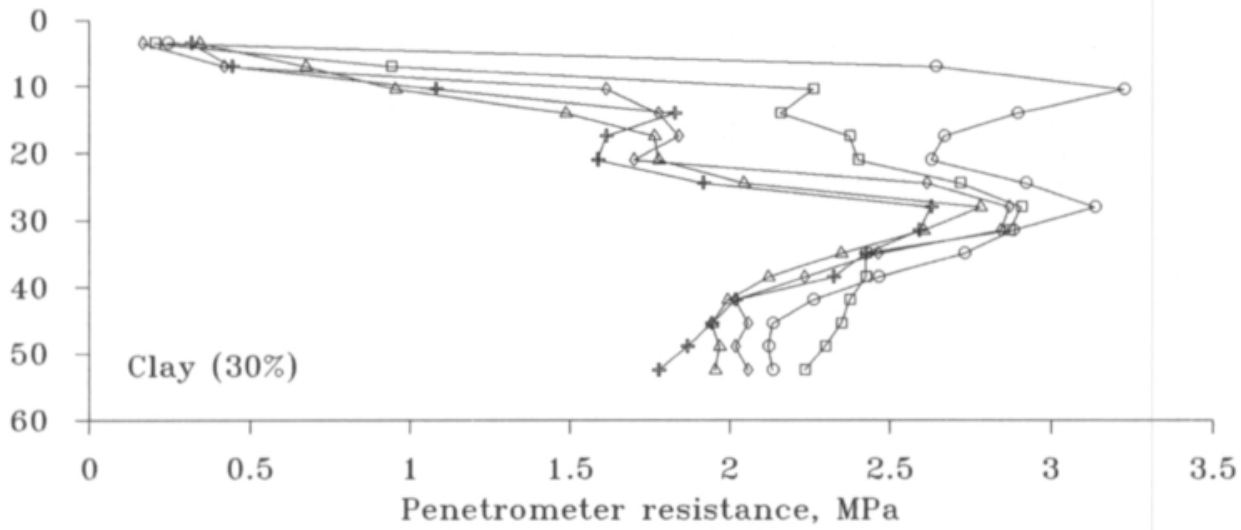

Depth, cm
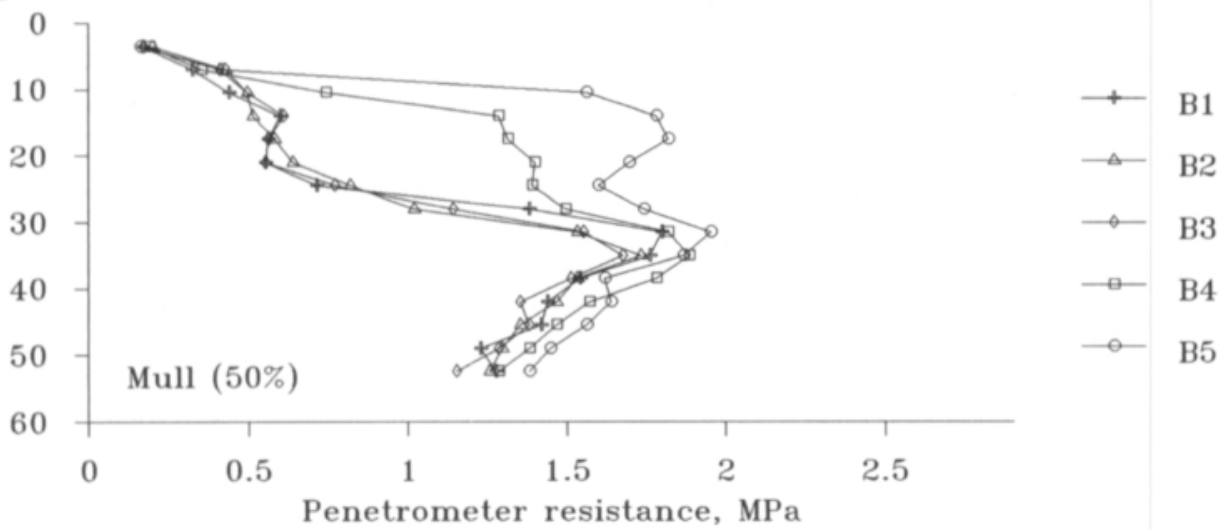

Fig. 14. Penetrometer resistance of experimental soils under dry conditions as affected by soil depth and soil mechanical treatments ( $\mathrm{B}_{1}-\mathrm{B}_{5}$ ), on 5 July 1989 (for mull 17 July 1991). Plant-available water content by gysum block recordings (\%) at the depth of $15 \mathrm{~cm}$ in parentheses. $\mathrm{B}_{1}=$ soil loosening by ridge preparation, $\mathrm{B}_{2}=$ soil loosening by rotary harrowing, $\mathrm{B}_{3}=$ untreated, $\mathrm{B}_{4}=$ one pass of the tractor wheel, $\mathrm{B}_{5}=$ three passes of the tractor wheel.

$\mathrm{HSD}_{e \text { os }}$ and average resistances at the depths of $7.0-17.5 \mathrm{~cm}$ and $24.5-35 \mathrm{~cm}$ in Tables 7 and 8 (mull) 
Pietola, L.: Effect of soil compactness on the growth and quality of carrot

Table 7. Penetrometer resistance (MPa) of loosened and compacted soils. Measurements were done under dry conditions on 5 July 1989 (plant-available water content at the depth of $15 \mathrm{~cm}$ by gypsum blocks $10 \%$ for fine sand, $30 \%$ for clay).

\begin{tabular}{|c|c|c|c|c|c|c|}
\hline \multirow{2}{*}{$\begin{array}{l}\text { Soil } \\
\text { depth, cm }\end{array}$} & \multicolumn{2}{|c|}{ Soil loosening1) } & \multicolumn{3}{|c|}{ Tractor wheel passes (n) } & \multirow[t]{2}{*}{$\mathrm{HSD}_{0.05}$} \\
\hline & 1 & 2 & 0 & 1 & 3 & \\
\hline \multicolumn{7}{|l|}{ Fine sand } \\
\hline $7.0-17.5$ & 0.51 & 0.45 & 0.63 & 1.00 & 1.46 & 0.41 \\
\hline $24.5-35.0$ & 2.01 & 1.94 & 2.44 & 2.80 & 2.93 & 0.45 \\
\hline \multicolumn{7}{|l|}{ Clay } \\
\hline $7.0-17.5$ & 1.24 & 1.22 & 1.41 & 1.93 & 2.86 & 0.81 \\
\hline $24.5-35.0$ & 2.39 & 2.44 & 2.70 & 2.73 & 2.92 & n.s. ${ }^{2)}$ \\
\hline
\end{tabular}

1) 1 = ridge preparation, 2 = rotary harrowing

${ }^{2)}$ n.s. = not significant

Table 8. Penetrometer resistance (MPa) of loosened and compacted soils under different soil moisture conditions. Depth $1=7.0-15.5 \mathrm{~cm}$, Depth 2 $=24.5-35 \mathrm{~cm} . \mathrm{A}_{0}=$ non-irrigated, $\mathrm{A}_{1}=$ irrigated. Soil moisture refers to plant-available water content by gypsum block recordings at depths of $15 \mathrm{~cm}$ and $30 \mathrm{~cm}$.

\begin{tabular}{|c|c|c|c|c|c|c|c|}
\hline \multirow{2}{*}{$\begin{array}{l}\text { Gypsum } \\
\text { block, } \\
\%\end{array}$} & \multirow[t]{2}{*}{ Depth } & \multicolumn{2}{|c|}{ Soil loosening1) } & \multicolumn{3}{|c|}{ Tractor wheel passes (n) } & \multirow[t]{2}{*}{$\mathrm{HSD}_{0.05}$} \\
\hline & & 1 & 2 & 0 & 1 & 3 & \\
\hline
\end{tabular}

Fine sand, 13 June 1990

$\begin{array}{llllllll}\mathrm{A}_{0}: & & & & & & \\ 55 & 1 & 0.76 & 0.34 & 0.84 & 1.76 & 2.76 & 0.46 \\ 80 & 2 & 1.95 & 2.02 & 2.44 & 3.14 & 2.90 & 0.69 \\ \mathrm{~A}_{1}: & & & & & & & \\ 90 & 1 & 0.28 & 0.10 & 0.32 & 0.53 & 1.06 & 0.42 \\ 90 & 2 & 1.96 & 2.27 & 2.19 & 2.30 & 2.89 & 0.75\end{array}$

Fine sand, 7 July 1990

\begin{tabular}{|c|c|c|c|c|c|c|c|}
\hline $\begin{array}{l}A_{0}: \\
45\end{array}$ & 1 & 0.77 & 0.20 & 0.54 & 1.31 & 1.60 & 0.32 \\
\hline 30 & 2 & 2.85 & 3.02 & 3.16 & 3.83 & $>4$ & 0.48 \\
\hline \multicolumn{8}{|l|}{$A_{1}:$} \\
\hline 90 & 1 & 0.36 & 0.24 & 0.39 & 0.57 & 0.91 & 0.18 \\
\hline 90 & 2 & 2.01 & 2.16 & 2.36 & 2.46 & 3.22 & 0.43 \\
\hline \multicolumn{8}{|c|}{ Mull, 13 May 1991} \\
\hline$A_{0}:$ & & & & & & & \\
\hline 85 & 1 & 0.21 & 0.18 & 0.25 & 0.45 & 0.75 & 0.13 \\
\hline 30 & 2 & 0.78 & 0.80 & 0.80 & 1.01 & 1.19 & 0.17 \\
\hline \multicolumn{8}{|c|}{ Mull, 3 July 1991} \\
\hline $\mathrm{A}_{0}$ : & & & & & & & \\
\hline 85 & 1 & 0.38 & 0.32 & 0.37 & 0.59 & 0.86 & 0.11 \\
\hline 90 & 2 & 0.93 & 0.90 & 0.86 & 1.16 & 1.25 & 0.29 \\
\hline \multicolumn{8}{|c|}{ Mull, 17 July 1991} \\
\hline$A_{0}:$ & & & & & & & \\
\hline 50 & 1 & 0.48 & 0.50 & 0.52 & 0.92 & 1.40 & 0.20 \\
\hline 75 & 2 & 1.41 & 1.28 & 1.29 & 1.65 & 1.79 & 0.42 \\
\hline
\end{tabular}

1) 1 = ridge preparation, 2 = rotary harrowing 


\section{AGRICULTURAL SCIENCE IN FINLAND}

Vol. 4: 139-237.
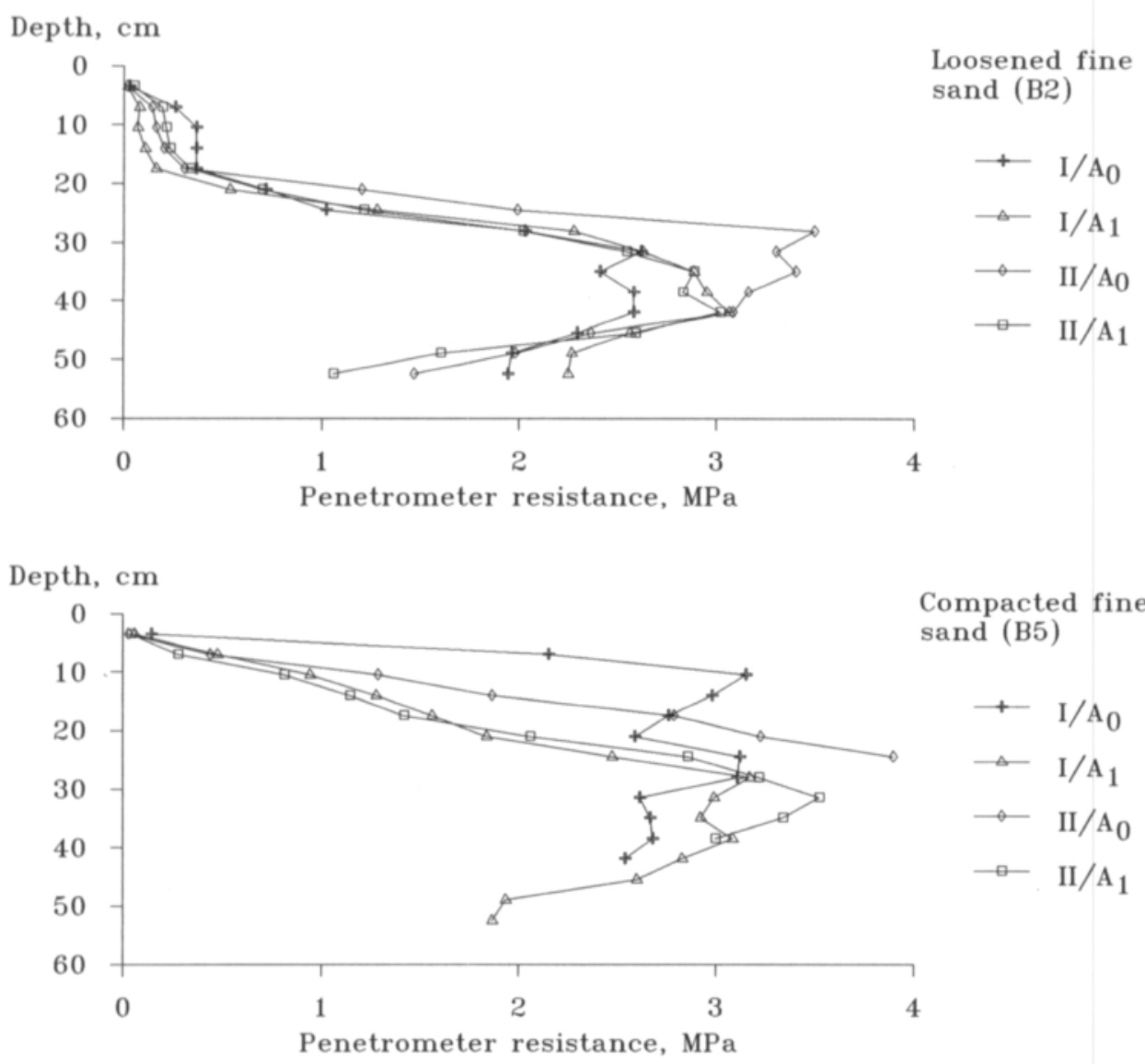

Fig. 15. Penetrometer resistance of fine sand at different recording times in $1990(\mathrm{I}=13 \mathrm{June}, \mathrm{II}=17 \mathrm{July})$ as affected by soil depth, soil rotary harrowing $\left(\mathrm{B}_{2}\right)$ and three passes of the tractor wheel $\left(\mathrm{B}_{5}\right)$ in non-irrigated soil $\left(\mathrm{A}_{0}\right)$ and in irrigated soil $\left(A_{1}\right)$.

$\mathrm{HSD}_{\mathrm{eas}}$, soil moisture and average resistances at the depths of $7.0-17.5 \mathrm{~cm}$ and $24.5-35 \mathrm{~cm}$ in Table 8 .

soil $\left(\mathrm{B}_{5}\right)$ than in loose soil $\left(\mathrm{B}_{2}\right)$. The changes of penetrometer resistance between $\mathrm{A}_{0}$ and $\mathrm{A}_{1}$ plots in fine sand at the first measurement indicate an effect of water application of $10 \mathrm{~mm}$ because the penetrometer resistances were measured between two nights of irrigation. At the second measurement, resistances of subsoils of non-irrigated compacted fine sand plots were at the upper limit of the pressure which could be measured by the penetrometer (4 MPa).

\section{Relation to soil moisture and dry bulk density}

For sandy soil in 1990 at the depth of 7.5-17.5 $\mathrm{cm}$, penetrometer resistance was related to soil gravimetric water content $(\mathrm{r}=-0.59 * * *)$ and to dry bulk density $(r=0.79 * * *)$. Soil dry bulk density alone explained the penetrometer resistance as much as $63 \%\left(R^{2}\right)$. Only a slightly higher coefficient of determination $\left(\mathrm{R}^{2}=68 \%\right)$ was attained by including soil moisture in the regres- 


\section{AGRICULTURAL SCIENCE IN FINLAND}

Pietola, L.: Effect of soil compactness on the growth and quality of carrot
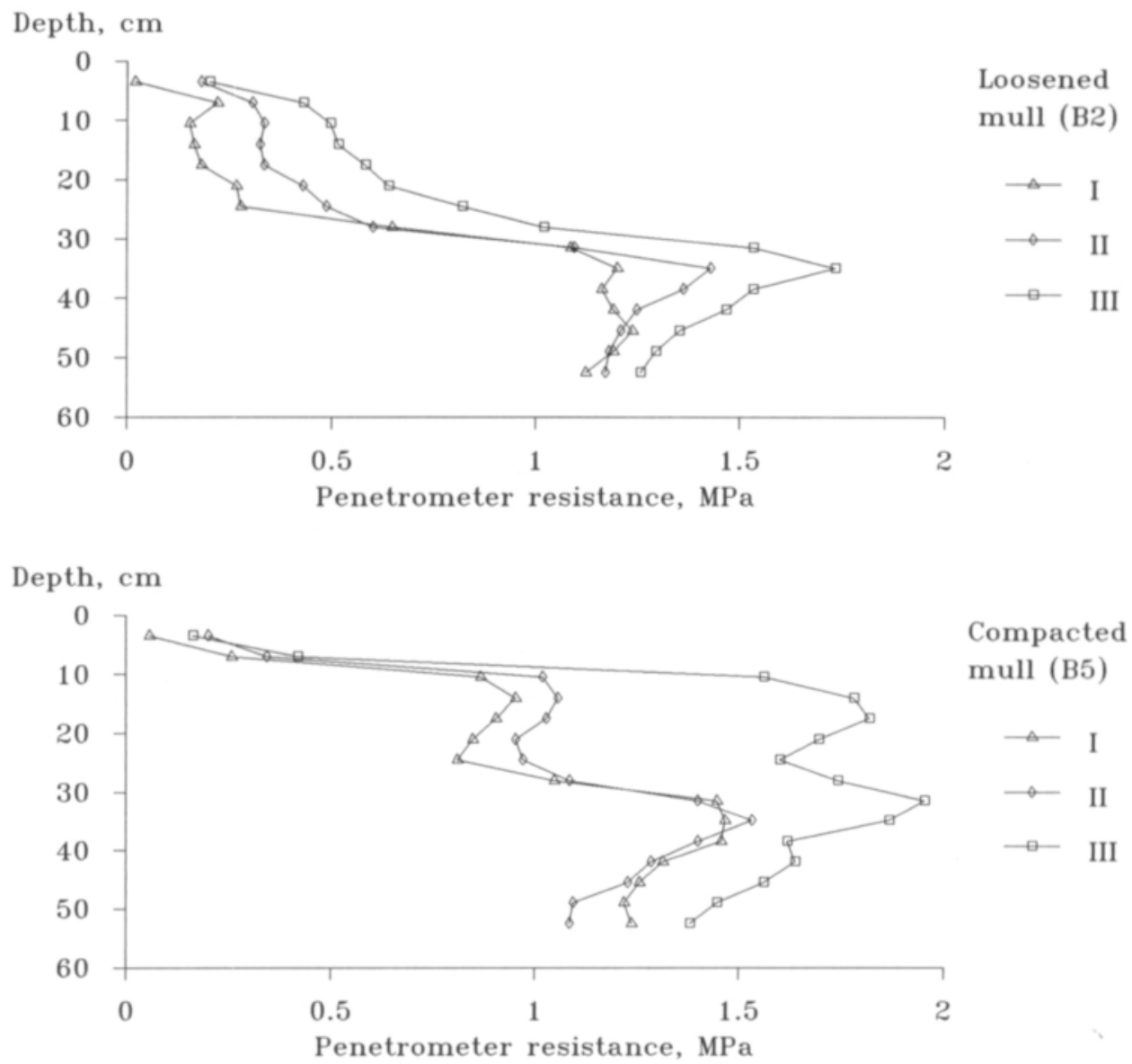

Fig. 16. Penetrometer resistance of mull at different recording times in $1991(\mathrm{I}=13 \mathrm{May}, \mathrm{II}=3 \mathrm{July}, \mathrm{III}=17 \mathrm{July})$ as affected by soil depth, soil rotary harrowing $\left(\mathrm{B}_{2}\right)$ and three passes of the tractor wheel $\left(\mathrm{B}_{5}\right)$.

HSD $_{0.5}$, soil moisture and average resistances at the depths of 7.0-17.5 $\mathrm{cm}$ and $24.5-35 \mathrm{~cm}$ in Table 8 .

sion analysis. The regression equation $(\mathrm{P}<0.01)$ for penetrometer resistance $\left(Q_{p}, k P a\right)$, determined by soil bulk density $\left(\rho_{\mathrm{b}, \mathrm{gr}}, \mathrm{g} \mathrm{cm}^{-3}\right)$ and gravimetric water content $(w, \%)$, was as follows:

$$
\mathrm{Q}_{\mathrm{p}}=3455 \rho_{\mathrm{b}, \mathrm{gr}}-100 w-1700\left(\mathrm{R}^{2}=0.68\right)
$$

Soil volumetric water content $(\theta, \%)$ had a negligible effect on this regression $(\mathrm{P}<0.01)$ :

$$
\mathrm{Q}_{\mathrm{p}}=4915 \rho_{\text {b.gr }}-0.8 \theta-3515\left(\mathrm{R}^{2}=0.69\right)
$$

For mull in 1991, a close positive correlation was found between penetrometer resistance and soil dry bulk density $\left(\mathrm{r}=0.86^{* * *}\right)$. The penetrometer resistance was best explained by soil dry bulk density $\left(\mathrm{R}^{2}=74 \%\right)$. Like in fine sand, only a slightly higher coefficient of determination $\left(\mathrm{R}^{2}=77 \%\right)$ was attained by including soil moisture in the regression analysis. The regression equation $(\mathrm{P}<0.05)$ for penetrometer resistance $\left(Q_{p}, k P a\right)$, determined by soil bulk density $\left(\rho_{\mathrm{b}, \mathrm{gr}}, \mathrm{g} \mathrm{cm}^{-3}\right)$ and gravimetric water content $(w, \%)$, was as follows:

$$
\mathrm{Q}_{\mathrm{p}}=5870 \rho_{\mathrm{b}, \mathrm{gr}}+30 w-4645 \quad\left(\mathrm{R}^{2}=0.77\right)
$$


Vol. 4: 139-237.

Table 9. Volume fraction $(\%)$ of macropores $(>30 \mu \mathrm{m})$ in loosened and compacted soils. At the sampling time in September 1990 (clay 1989) soil moisture condition was near field capacity $\left(\psi_{\mathrm{m}} \approx-10 \mathrm{kPa}\right)$.

\begin{tabular}{|c|c|c|c|c|c|c|}
\hline \multirow{2}{*}{$\begin{array}{l}\text { Soil } \\
\text { depth, cm }\end{array}$} & \multicolumn{2}{|c|}{ Soil loosening1) } & \multicolumn{3}{|c|}{ Tractor wheel passes (n) } & \multirow[t]{2}{*}{$\mathrm{HSD}_{0.04}$} \\
\hline & 1 & 2 & 0 & 1 & 3 & \\
\hline \multicolumn{7}{|l|}{ Fine sand } \\
\hline $2.5-7.5$ & 31.2 & 28.4 & 25.9 & 22.7 & 19.6 & 3.6 \\
\hline $12.5-17.5$ & 23.4 & 26.9 & 24.3 & 18.8 & 17.5 & 5.8 \\
\hline $22.5-27.5$ & n.d. ${ }^{2)}$ & 18.1 & 17.8 & 15.1 & 16.5 & n.s. ${ }^{3)}$ \\
\hline $32.5-37.5$ & n.d. & 17.9 & 19.6 & 15.3 & 16.6 & n.s. \\
\hline \multicolumn{7}{|l|}{ Mull } \\
\hline $2.5-7.5$ & 35.2 & 30.2 & 24.9 & 24.6 & 17.1 & 4.5 \\
\hline $12.5-17.5$ & 26.6 & 28.4 & 25.6 & 19.0 & 15.1 & 6.1 \\
\hline $22.5-27.5$ & n.d. & 27.8 & 25.0 & 20.0 & 17.7 & 5.6 \\
\hline $32.5-37.5$ & n.d. & 26.1 & 28.5 & 24.1 & 27.0 & n.s. \\
\hline \multicolumn{7}{|l|}{ Clay } \\
\hline $2.5-7.5$ & n.d. & 32.9 & 34.5 & n.d. & 24.7 & n.s. \\
\hline $12.5-17.5$ & n.d. & 20.8 & 17.0 & n.d. & 8.4 & n.s. \\
\hline $22.5-27.5$ & n.d. & 13.1 & 9.0 & n.d. & 12.4 & n.s. \\
\hline $32.5-37.5$ & n.d. & 6.4 & 5.4 & n.d. & 12.6 & n.s. \\
\hline
\end{tabular}

1) 1 = ridge preparation, 2 = rotary harrowing

${ }^{2)}$ n.d. = not determined

${ }^{3)}$ n.s. = not significant

Also soil volumetric water content $(\theta, \%)$ had a negligible effect on this regression $(\mathrm{P}<0.06)$ :

$$
\mathrm{Q}_{\mathrm{p}}=3190 \rho_{\mathrm{b}, \mathrm{gr}}+0.4 \theta-2840 \quad\left(\mathrm{R}^{2}=0.77\right)
$$

The decreasing effect of high soil water content on penetrometer resistance (Figs. 15 and 16, Table 8 ) was shown by these regression analyses only in fine sand with soil gravimetric water content.

\section{I.5 Soil porosity and water retention capacity}

\section{Pore volume}

Comparison of total porosity and pore size distribution, as affected by soil mechanical treatments (Table 9, Fig. 17), indicates a significant role for soil compaction in the volume of ma- cropores (equivalent diameter $>30 \mu \mathrm{m}$ ). Even if the total porosity decreased by increasing soil compactness, the differences between total pore volume were smaller than between macroporosity as a result of the increase of small $(<0.2 \mu \mathrm{m})$ and, to some extent, of medium-size pores.

In fine sand and mull, total porosity decreased significantly $(\mathrm{P}<0.05)$ by soil compaction to the depth of $27.5 \mathrm{~cm}$ while the volume of medium-size pores increased in comparison with loose soil profiles. To the depth $17.5 \mathrm{~cm}$, the total volume of small pores was 1-2 percentage units higher in compacted fine sand than in loose fine sand. At mull soil surface $(2.5-7.5 \mathrm{~cm})$, the total porosity of $\mathrm{B}_{1}$ treatment was significantly higher than in $\mathrm{B}_{3}$ treatment and in compacted $\mathrm{B}_{4}$ and $\mathrm{B}_{5}$ treatments. Here, too, compaction increased the volume of small pores to the depth of $17.5 \mathrm{~cm}$. Moreover, at a depth of 12.5$17.5 \mathrm{~cm}$, even one mull soil wheel traffic increased the portion of small pores by 3-4 per- 


\section{AGRICULTURAL SCIENCE IN FINLAND}

Pietola, L.: Effect of soil compactness on the growth and quality of carrot

Depth, cm
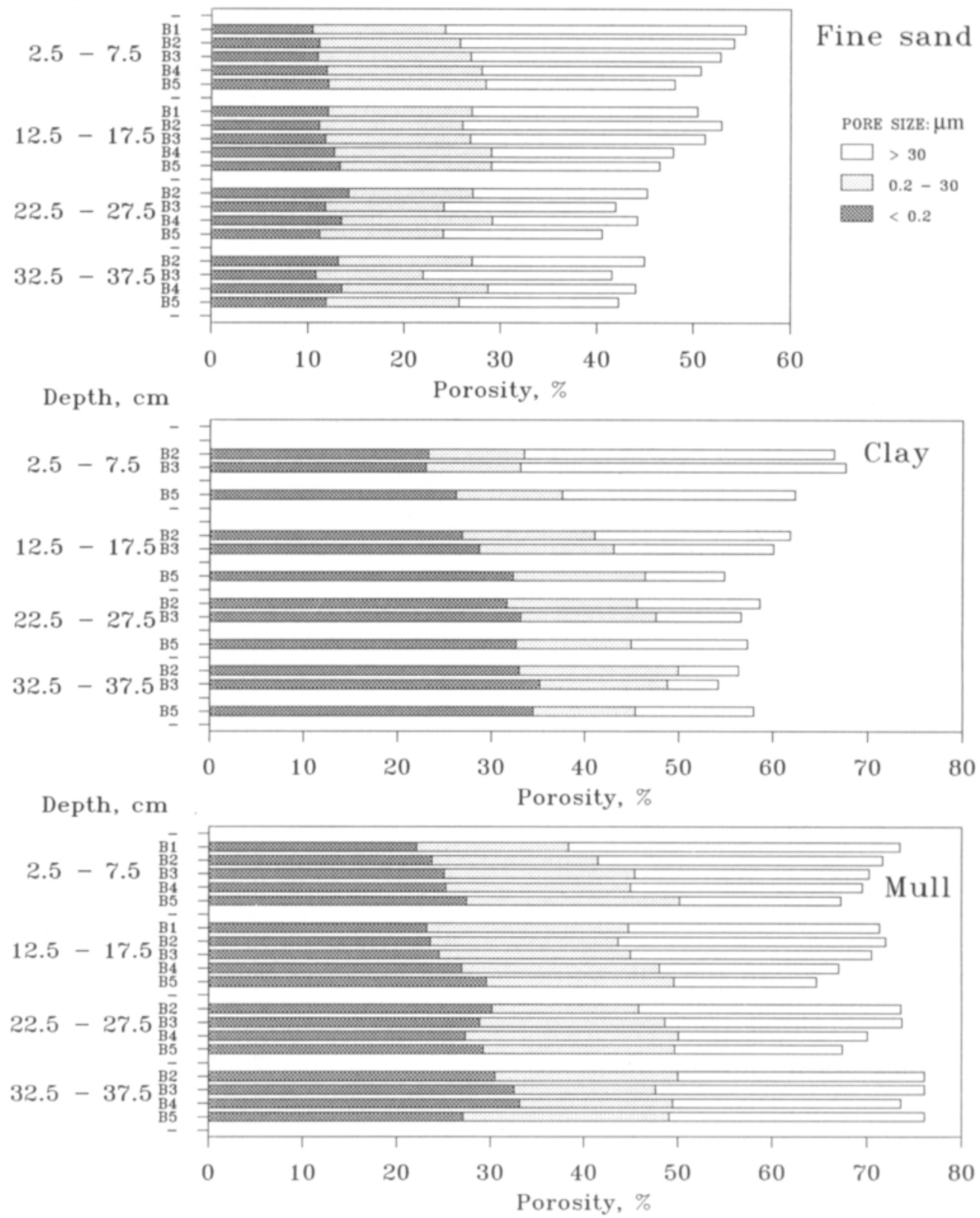

Fig. 17. Total porosity and volumetric pore size distribution of experimental soils as affected by soil depth and soil mechanical treatments $\left(\mathrm{B}_{1}-\mathrm{B}_{5}\right)$, based on core sampling near field capacity $\left(\psi_{\mathrm{m}} \approx-10 \mathrm{kPa}\right) . \mathrm{B}_{1}=$ soil loosening by ridge preparation, $\mathrm{B}_{2}=$ soil loosening by rotary harrowing, $\mathrm{B}_{3}=$ untreated, $\mathrm{B}_{4}=$ one pass of the tractor wheel, $\mathrm{B}_{5}=$ three passes of the tractor wheel.

$\mathrm{HSD}_{0.05}$ for significant differences:

Total porosity: in fine sand $2 \%$ at $2.5-7.5 \mathrm{~cm}, 3 \%$ at $12.5-17.5 \mathrm{~cm}, 3 \%$ at $22.5-27.5 \mathrm{~cm}$; in mull $3 \%$ at $2.5-7.5 \mathrm{~cm}, 4 \%$ at $12.5-17.5 \mathrm{~cm}, 7 \%$ at $22.5-27.5 \mathrm{~cm}$ Macropores: in Table 9.

Medium-size pores: in fine sand $2 \%$ at $2.5-17.5 \mathrm{~cm}$; in mull $3 \%$ at $2.5-7.5 \mathrm{~cm}$

Micropores: in fine sand $1 \%$ at $2.5-17.5 \mathrm{~cm}, 2 \%$ at $32.5-37.5 \mathrm{~cm}$; in mull $3 \%$ at $2.5-17.5 \mathrm{~cm}$ 
Vol. 4: 139-237.

Table 10. Volumetric water content $(\%)$ of loosened and compacted soils at $\psi_{\mathrm{m}}=-10 \mathrm{kPa}$, collected near field capacity $\left(\psi_{\mathrm{m}} \approx-10 \mathrm{kPa}\right)$ in September 1990 (clay 1989).

\begin{tabular}{|c|c|c|c|c|c|c|}
\hline \multirow{2}{*}{$\begin{array}{l}\text { Soil } \\
\text { depth, cm }\end{array}$} & \multicolumn{2}{|c|}{ Soil loosening ${ }^{1)}$} & \multicolumn{3}{|c|}{ Tractor wheel passes (n) } & \multirow[t]{2}{*}{$\mathrm{HSD}_{0.05}$} \\
\hline & 1 & 2 & 0 & 1 & 3 & \\
\hline \multicolumn{7}{|l|}{ Fine sand } \\
\hline $2.5-7.5$ & 24.2 & 25.8 & 26.9 & 28.0 & 28.5 & 1.8 \\
\hline $12.5-17.5$ & 27.0 & 26.0 & 26.8 & 29.1 & 29.0 & 2.7 \\
\hline $22.5-27.5$ & n.d. ${ }^{2)}$ & 27.1 & 24.1 & 29.2 & 24.1 & 4.1 \\
\hline $32.5-37.5$ & n.d. & 26.3 & 22.0 & 28.7 & 25.7 & n.s. ${ }^{3)}$ \\
\hline \multicolumn{7}{|l|}{ Mull } \\
\hline $2.5-7.5$ & 38.3 & 41.5 & 45.4 & 44.9 & 50.2 & 3.2 \\
\hline $12.5-17.5$ & 44.7 & 43.6 & 44.9 & 48.0 & 49.6 & 4.4 \\
\hline $22.5-27.5$ & n.d. & 45.8 & 48.7 & 50.1 & 49.7 & n.s \\
\hline $32.5-37.5$ & n.d. & 50.0 & 47.6 & 49.5 & 49.1 & n.s. \\
\hline \multicolumn{7}{|l|}{ Clay } \\
\hline $2.5-7.5$ & n.d. & 33.5 & 33.1 & n.d. & 37.6 & n.s. \\
\hline $12.5-17.5$ & n.d. & 41.0 & 43.1 & n.d. & 46.5 & n.s \\
\hline $22.5-27.5$ & n.d. & 45.6 & 47.6 & n.d. & 44.9 & n.s. \\
\hline $32.5-37.5$ & n.d. & 49.9 & 48.8 & n.d. & 45.4 & n.s. \\
\hline
\end{tabular}

\footnotetext{
1) 1 = ridge preparation, 2 = rotary harrowing

${ }^{2)}$ n.d. = not determined

${ }^{3)}$ n.s. = not significant
}

centage units as compared with loose soil profiles. For medium-size pores, significant differences between treatments were found only in the surface layer. However, these differences were negligible as compared with the differences around $50 \%$ in macroporosity (Table 9).

Despite the few statistically significant differences in clay soil porosity between treatments (because of lack of subsamples of a heterogeneous soil type), the differences are worth mentioning because of their magnitude. In the surface layer, three tractor passes decreased the total pore volume by 5.3 percentage units as compared with $\mathrm{B}_{3}$ treatment $\left(\mathrm{HSD}_{0.05}=5.4\right)$. Again, at a depth of $12.5-17.5 \mathrm{~cm}$, total porosity decreased as much as 7 percentage units by three tractor passes $\left(\mathrm{HSD}_{0.05}=9\right)$ as compared with the porosity of $\mathrm{B}_{2}$ treatment. These differences were mainly due to the variation in the total volume of large pores which was relatively most distinct at $12.5-17.5 \mathrm{~cm}$ (Table 9). In the sur- face layer, comparison of the macroporosity in compacted and non-compacted soils indicated a decrease in pore volume of 10 percentage units by soil compaction. Deeper, at $12.5-17.5 \mathrm{~cm}$, this decrease was 12 percentage units as compared with macropores in loosened soil $\left(\mathrm{B}_{2}\right)$.

Like in fine sand and mull, the volume of small pores increased by clay soil compaction more than medium-size pores. At a depth of $12.5-17.5 \mathrm{~cm}$, the volume of small pores increased by soil compaction by as much as 5.4 percentage units $\left(\mathrm{HSD}_{0.05}\right.$ $=6.4)$ as compared with rotary harrowing $\left(B_{2}\right)$. No effect of mechanical treatments on pore size distribution was, however, observed below the plough layer of clay soil.

\section{Water retention}

No remarkable effect of mechanical treatment on the plant-available water capacity was found, as indicated by the distributions of medium-size 
Pietola, L.: Effect of soil compactness on the growth and quality of carrot

$\begin{array}{lrrrr}\text { Oxygen, } & \mathrm{A}_{0} & \begin{array}{c}\text { Carbon dioxide, } \\ \% \text { in soil air }\end{array} & \begin{array}{l}\text { Oxygen, } \\ \text { in soil air }\end{array} & \mathrm{A}_{1} \text { in soil air }\end{array}$
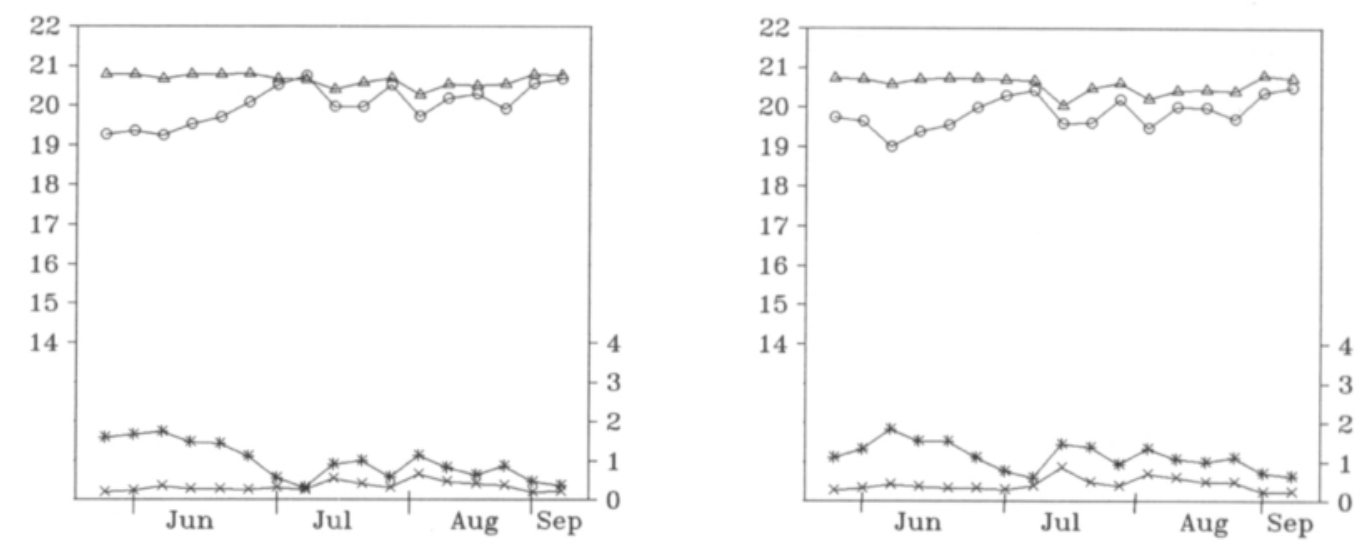

Oxygen,

$\%$ in soil air
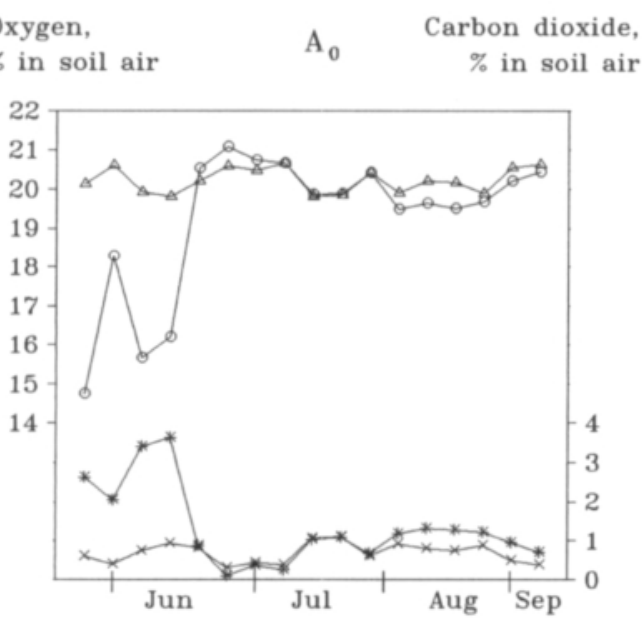

Oxygen:

$\triangle$ B3 $\rightarrow$ B5
Oxygen,

$\%$ in soil air

$\mathrm{A}_{1}$

Carbon dioxide, $\%$ in soil air

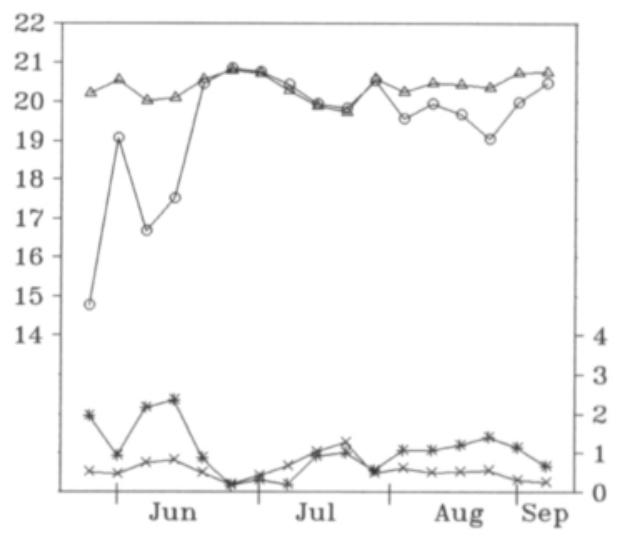

Carbon dioxide:

* B3 $\rightarrow$ B5

Fig. 18. Soil air $\mathrm{O}_{2}$ and $\mathrm{CO}_{2}$ contents of fine sand (above) and clay (below) as affected by soil mechanical treatments ( $\left.\mathrm{B}_{3}, \mathrm{~B}_{5}\right)$ and irrigation at the depth of $15 \mathrm{~cm}$ during the growing period $1989 . \mathrm{A}_{0}=$ no irrigation (left), $\mathrm{A}_{1}=$ sprinkler irrigation (right). $\mathrm{B}_{3}=$ untreated, $\mathrm{B}_{5}=$ three passes of the tractor wheel.

$\mathrm{HSD}_{0.05}$ for significant differences:

$\mathrm{O}_{2}$ : in fine sand $1.1 \%$ (at the same A level $1.5 \%$ ) on 22 May, $1.0 \%(1.4 \%)$ on 29 May and 5 June, $0.9 \%$ (1.3\%) on 12 June, $0.7 \%(1.0 \%)$ on 19 June, $0.5 \%(0.7 \%)$ on June 26 ; in clay $2.0 \%(2.9 \%)$ on 29 May, $4.1 \%(5.7 \%)$ on 5 June, $3.4 \%(4.8 \%)$ on 12 June, $0.5 \%(0.7 \%)$ on 14 August- 4 September $\mathrm{CO}_{2}$ : close to that of $\mathrm{O}_{2}$

pores (Fig. 17). However, the effects of mechanical treatments on water retention capacities on volume basis at the matric potential of $-10 \mathrm{kPa}$ were more significant, as indicated by the por- tions of pore sizes of $0-30 \mu \mathrm{m}$ (Fig. 17 and Table 10). Also soil volumetric water content at a matric potential of $-1500 \mathrm{kPa}$, i.e. the volume of small pores in Figure 17, increased by soil 
Vol. 4: 139-237.
Oxygen,
$\%$ in soil air
Carbon dioxide,
\% in soil air
Oxygen,
$\%$ in soil air
$\mathrm{A}_{1}$
Carbon dioxide,
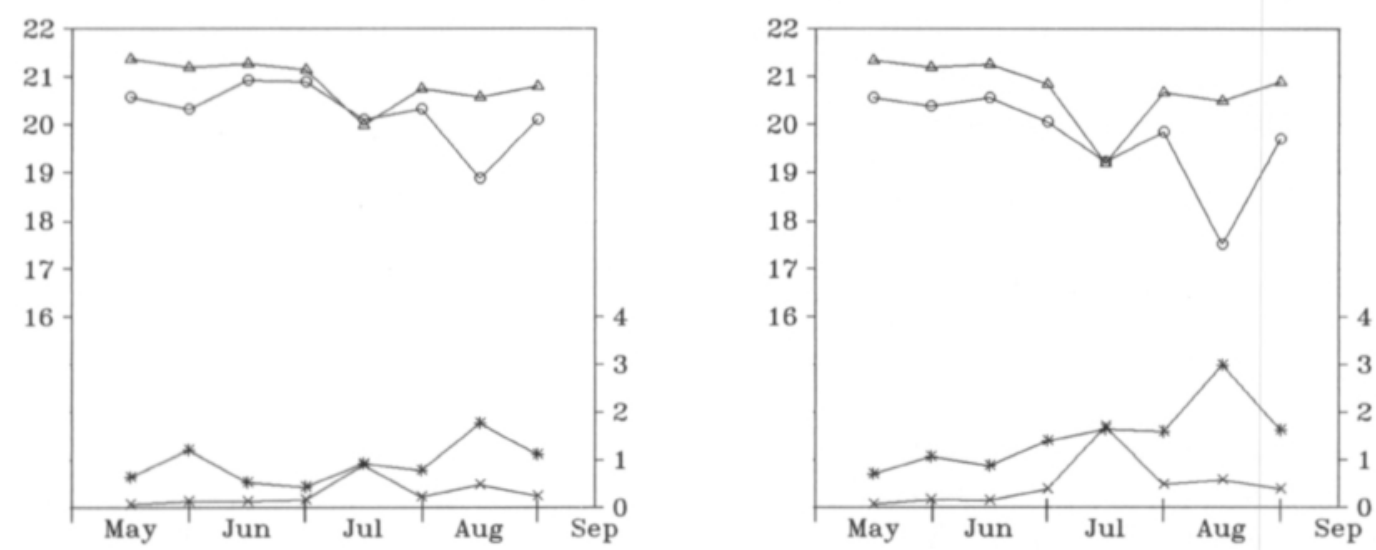

Oxygen,

$\%$ in soil air

$\mathrm{A}_{0} \quad$ Carbon dioxide,

Oxygen,

$\%$ in soil air

Carbon dioxide,
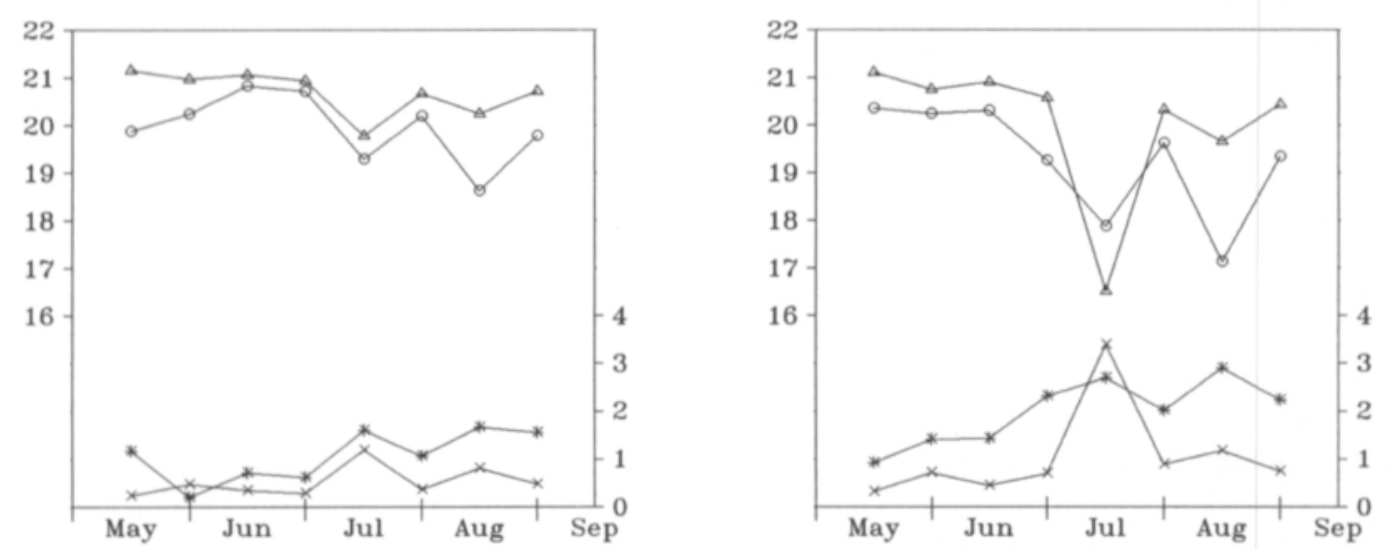

Oxygen:

Carbon dioxide:

$\triangle$ B2 $\rightarrow$ B5

* B2 * B5

Fig. 19. Soil air $\mathrm{O}_{2}$ and $\mathrm{CO}_{2}$ contents of fine sand at the depths of $15 \mathrm{~cm}$ (above) and $30 \mathrm{~cm}$ (below) as affected by soil mechanical treatments $\left(B_{2}, B_{5}\right)$ and irrigation during the growing period 1990. $A_{0}=$ no irrigation (left), $A_{1}=$ irrigation (right). $\mathrm{B}_{2}=$ rotary harrowing, $\mathrm{B}_{5}=$ three passes of the tractor wheel.

HSD $_{005}$ for significant differences:

$\mathrm{O}_{\text {; }}$ at $15 \mathrm{~cm} 0.6 \%$ (at the same A level $0.8 \%$ ) on $30 \mathrm{May}, 0.2 \%(0.3 \%)$ on 25 June, $0.2 \%(0.2 \%)$ on 9 July and 6 August, $0.8 \%(1.1 \%)$ on 20 August,

$0.3 \%(0.5 \%)$ on 6 September, at $30 \mathrm{~cm}$ differences significant between B treatments, except on 23 July

$\mathrm{CO}_{2}$ : close to that of $\mathrm{O}_{2}$

compaction, especially in clay and mull. These results suggest higher water retention for the experimental soils after compaction than after loosening below the suction at field capacity $\left(\psi_{m} \leq-10 \mathrm{kPa}\right)$. This was observed also by soil water content measurements on volume basis right after sowing in 1991 (Table 4, p. 167). 
Pietola, L.: Effect of soil compactness on the growth and quality of carrot

\section{I.6 Soil air composition}

Composition of soil air was measured at a depth of $15 \mathrm{~cm}$ in 1989 and at depths of 15 and $30 \mathrm{~cm}$ in 1990 during the growing seasons. Generally, the oxygen content was lower than normal in early summer when soil water contents were high (Figs. 18-20). The precipitation and irrigations (Figs. 7-9) decreased the oxygen content while soil compaction decreased the content most in irrigated plots. Air composition in fine sand was not, however, significantly affected by the irrigations in 1989, when the drought at the beginning of July affected all plots. Oxygen content of fine sand decreased and carbon dioxide content increased by soil compaction in June 1989, but only around one percentage unit as compared to untreated soil $\left(\mathrm{B}_{3}\right)$ or to narrow ridges $\left(\mathrm{B}_{1}\right)$. Later, the measured differences of around 0.5 percentage units for both oxygen and carbon dioxide contents between untreated (or loosened) and compacted soils were still statistically significant.

Even though soil moisture affected soil air composition in early summer, two applications of water $(2 \times 30 \mathrm{~cm})$ at the beginning of July did not affect the oxygen or carbon dioxide contents in clay soil. The first amount of water applied at the beginning of July 1989 was too small for the dry clay soil to maintain moist soil conditions for more than a few days. Thus, a second water application was needed after 5 days. The dry period continued at the end of July. Thereafter precipitation was enough for plant growth but did not create a difference greater than 1 percentage unit in oxygen or carbon dioxide content between loose and compacted soil. At the beginning of the growing period 1989, oxygen content at a depth of $15 \mathrm{~cm}$ was significantly lower in compacted $\left(\mathrm{B}_{5}\right)$ than in untreated $\left(\mathrm{B}_{3}\right)$ clay soil (Fig. $18)$. In narrow ridges $\left(B_{1}\right)$, soil oxygen content was about the same as in treatment $\mathrm{B}_{3}$ (only $0.2-$ 0.3 percentage units higher, not presented in Fig. 18). This decrease in oxygen content by clay soil compaction was $2-5$ percentage units, and it lasted for about the first 4 weeks after sowing. Similarly, the increase of carbon dioxide content was

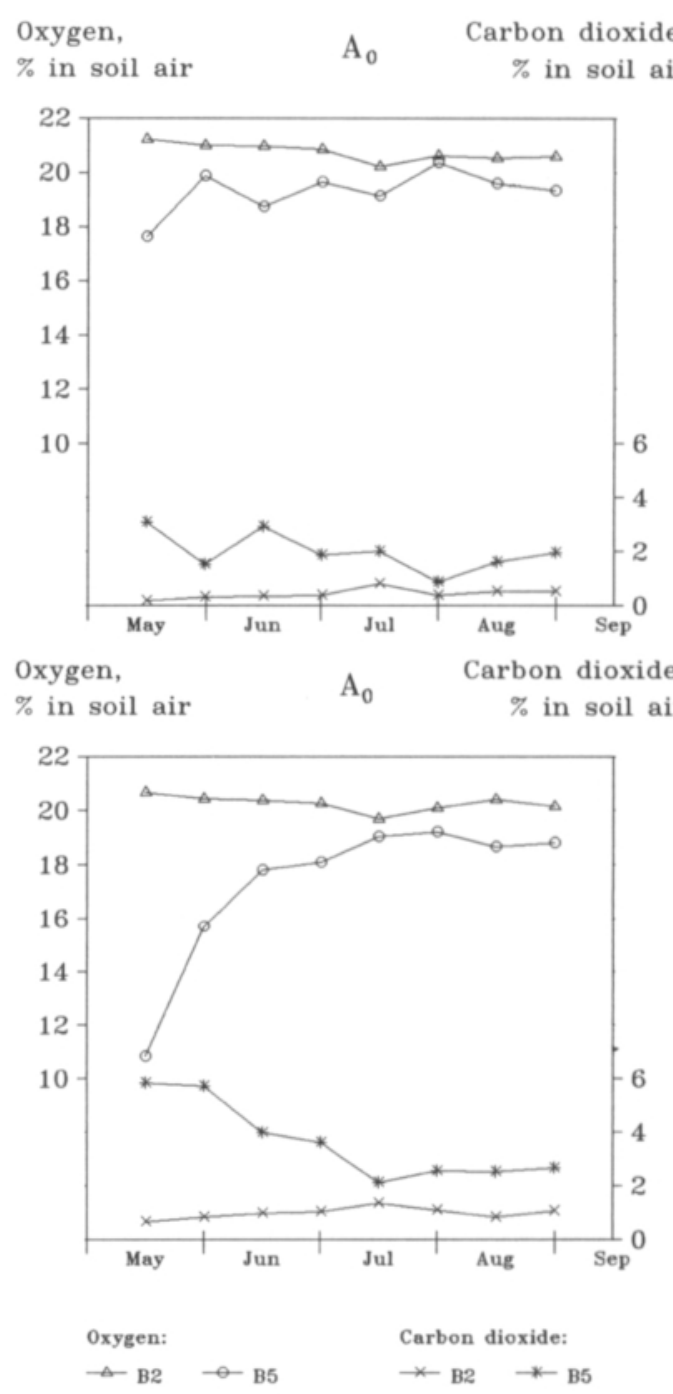

Fig. 20. Soil air $\mathrm{O}_{2}$ and $\mathrm{CO}_{2}$ contents of mull at the depths of $15 \mathrm{~cm}$ (above) and $30 \mathrm{~cm}$ (below) as affected by soil mechanical treatments $\left(\mathrm{B}_{2}, \mathrm{~B}_{5}\right)$ during the growing period 1990. $B_{2}=$ rotary harrowing, $B_{5}=$ three tractor wheelings.

$\mathrm{HSD}_{\text {oos }}$ for significant differences:

$\mathrm{O}_{2}:$ at $15 \mathrm{~cm} 2.4 \%$ on 30 May, $1.0 \%$ on 20 August, $0.6 \%$ on 6 September; at $30 \mathrm{~cm} 4.9 \%$ on 30 May, $2.5 \%$ on 9 July, $1.4 \%$ on 20 August

$\mathrm{CO}_{2}$ : at $15 \mathrm{~cm}$ close to that of $\mathrm{O}_{2}$; at $30 \mathrm{~cm}$ differences significant, except on 25 June and 23 July

1.5-3 percentage units at the depth of $15 \mathrm{~cm}$. With advancing growing period, the differences in oxygen and carbon dioxide contents diminished between the mechanical treatments. 
Vol. 4: 139-237.

In 1990, soil air composition was measured at depths of 15 and $30 \mathrm{~cm}$, from the most loose $\left(\mathrm{B}_{2}\right)$ and compacted $\left(\mathrm{B}_{5}\right)$ fine sand and mull (Figs. 19-20). The effect of irrigation on soil air composition was more significant in 1990 than in 1989, reflecting the remarkable effect of irrigation on soil water contents in fine sand in 1990 (Fig. 7). In fine sand, the decreasing effect of irrigation on oxygen content was found at the depth of $15 \mathrm{~cm}$ in July 1990, after two water applications of $35 \mathrm{~mm}$ in June. In August, the effects were significant only at $\mathrm{P}<0.10$ at the depth of $15 \mathrm{~cm}$ (even though the difference was over 3 percentage units between irrigated and non-irrigated plots). At $30 \mathrm{~cm}$, however, the irrigations caused significantly lower oxygen and higher carbon dioxide contents than were measured in non-irrigated plots.

Comparison of oxygen and carbon dioxide contents in loose and compacted fine sand at the depth of $15 \mathrm{~cm}$ indicates differences of around one percentage unit at the beginning of the growing period 1990, but also in early autumn with high soil moisture content ( $85 \%$ plant-available water). Comparison of irrigated and non-irrigated soils indicates that soil air oxygen content decreased and carbon dioxide content increased by irrigation more in compacted than in loose soil. The interaction was significant on 9 July (at both depths) and 20 August (at $15 \mathrm{~cm}$ only at $\mathrm{P}<0.10$ ). In irrigated soil at the depth of $30 \mathrm{~cm}$, the greatest change in fine sand air composition with advancing growing period was found at the end of July when the oxygen content decreased on average to $17-18 \%$, the carbon dioxide content being $3 \%$. This might indicate a high respiration of carrot plant, as the tap root growth was most vigorous at this time. In 1989, this effect was not significant because of the low plant density, 20 carrots per row meter. The influence of soil mechanical treatments was not statistically significant due to the exceptionally great variation between replicates.

The results from mull field at the depth of 15 $\mathrm{cm}$ implied a statistically significant effect of soil compactness on soil air composition only at the first and the last two measuring dates in 1990
(Fig. 20). At the depth of $15 \mathrm{~cm}$, the changes in air composition were to some extent higher than in fine sand, as oxygen content decreased and carbon dioxide content increased by $1.5-3$ percentage units by compaction $\left(\mathrm{B}_{5}\right)$ as compared with $\mathrm{B}_{2}$ treatment. At $30 \mathrm{~cm}$, however, a much more negative effect of soil compaction on soil oxygen content than in fine sand was observed in the early summer, when the decrease of oxygen content was 3-10 percentage units and the increase of carbon dioxide content 3-5 percentage units. Later, the smaller differences of 1.52 percentage units were still statistically significant for carbon dioxide content, but only at $\mathrm{P}<0.10$ for oxygen content.

\subsection{Response of carrot growth and yield quality to treatments}

\subsection{Yield and external quality of tap roots}

\section{Biomass accumulation}

Visual observation of carrot emergence indicated a more even and faster shooting in the compacted plots than in loose soil. After plant thinning, some seedlings died, especially in loose mull in 1990, when the plant population remained lower ( 35 plants per metre) in narrow ridges than in other treatments ( 40 plants per metre). Additionally, seedlings grew much more slowly in mull than in fine sand.

In fine sand in 1989, tap root fresh weight was on average $10 \mathrm{~g}$ higher when irrigated as compared with no water applications at first sampling (Fig. 21). Similarly, shoot fresh weight was on average $13 \mathrm{~g}$ higher. This difference between two irrigation schemes was found also at the second sampling, but at harvest it had diminished to $5 \mathrm{~g}$ because of the adverse effect of water applications on shoot growth under intensively 


\section{AGRICULTURAL SCIENCE IN FINLAND}

Pietola, L.: Effect of soil compactness on the growth and quality of carrot

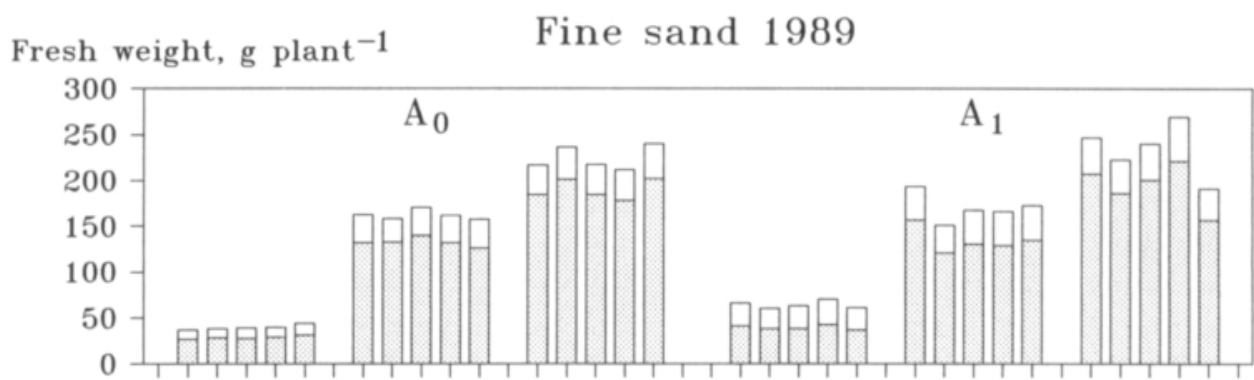

B: $12345-12345-12345-$ B: $12345-12345-12345-$

Mechanical treatment

$\begin{array}{llllll}\text { DAS } & 80 & 109 & 137 & 80 & 109\end{array}$

Fresh weight, g plant $^{-1} \quad$ Clay 1989

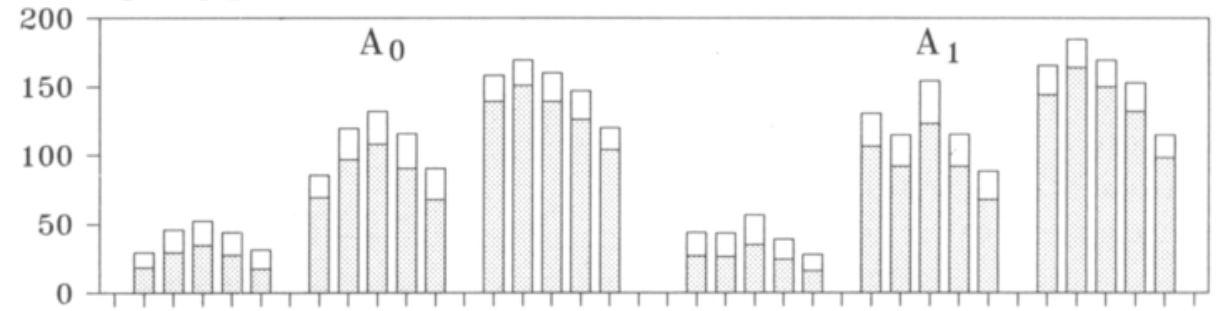

B: $12345-12345-12345-B: 12345-12345-12345-$

Mechanical treatment

$\begin{array}{lllllll}\text { DAS } & 81 & 108 & 140 & 81 & 108 & 140\end{array}$

Tap root $\square$ Shoot

Fig. 21. Mean shoot and tap root fresh weight $(n=15)$ as affected by soil mechanical treatments $\left(B_{1}-B_{5}\right)$ in clay and fine sand at three sampling times during the growing period 1989. DAS $=$ days after sowing. $A_{0}=$ no irrigation (left), $A_{1}=$ irrigation (right). $\mathrm{B}_{1}=$ soil loosening by ridge preparation, $\mathrm{B}_{2}=$ soil loosening by rotary harrowing, $\mathrm{B}_{3}=$ untreated, $\mathrm{B}_{4}=$ one pass of the tractor wheel, $\mathrm{B}_{5}=$ three passes of the tractor wheel.

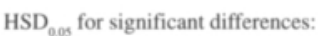

Tap roots: in clay $12 \mathrm{~g}$ (at the same A level $17 \mathrm{~g}$ ) 81 days after sowing (DAS), $23 \mathrm{~g}$ (32 g) $108 \mathrm{DAS}, 30 \mathrm{~g}$ (41 g) $140 \mathrm{DAS}$

Shoots: in clay $4 \mathrm{~g} \mathrm{(6g)} 81$ DAS, $6 \mathrm{~g} \mathrm{(8g)} 108$ DAS, $4 \mathrm{~g}(5 \mathrm{~g}) 140$ DAS

compacted conditions. As late as at the second sampling, shoots in irrigated and three times compacted plots were still significantly greater than in the irrigated loose $\mathrm{B}_{2}$ plot. Mechanical treatments alone did not have any significant influence on carrot biomass. However, interactions $(\mathrm{P}<0.05)$ were found between compaction and irrigation in carrot tap root and shoot development, as indicated by the second sampling 137 days after sowing. Tap root and shoot fresh weights in $\mathrm{B}_{5}$ treatments decreased only in irri- gated plots. An opposite effect was caused by one tractor pass $\left(\mathrm{B}_{4}\right)$.

In clay, irrigation had a significant positive effect on root growth only at the second sampling, when tap root mean weight increased by $10 \mathrm{~g}$ by water applications (Fig. 21). On average, irrigation did not affect either shoot growth or shoot to root ratio. Mechanical treatments had a very remarkable effect on carrot growth. The highest tap root fresh weight was attained by $\mathrm{B}_{3}$ treatment, while both very loose and compacted 
Vol. 4: 139-237.

Fresh weight, g plant ${ }^{-1}$

Fine sand 1990

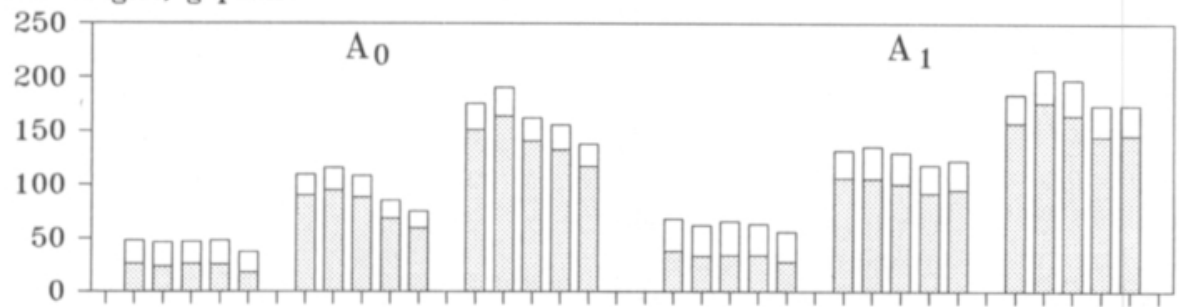

B: $12345-12345-12345-B: 12345-12345-12345$ -

Mechanical treatment

$\begin{array}{lrrrrrr}\text { DAS } & 89 & 123 & 158 & 89 & 123 & 158\end{array}$

Fresh weight, plant $^{-1}$

Fine sand 1991

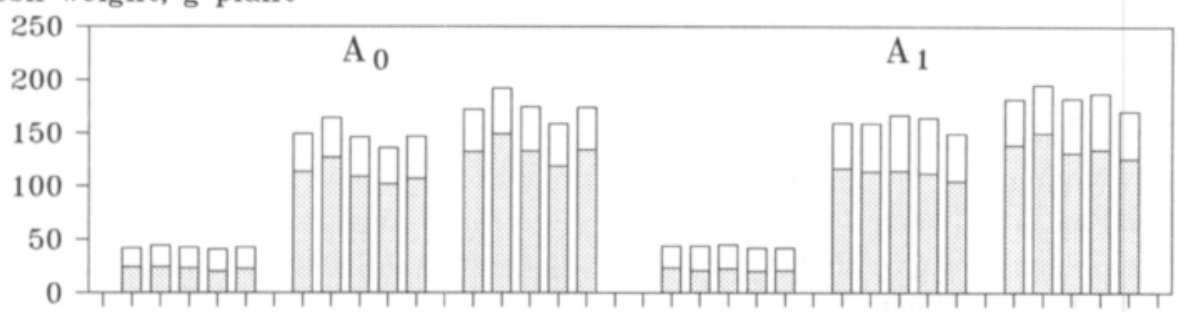

B: $12345-12345-12345-B: 12345-12345-12345-$

Mechanical treatment
DAS 90
117
145
90
117
145

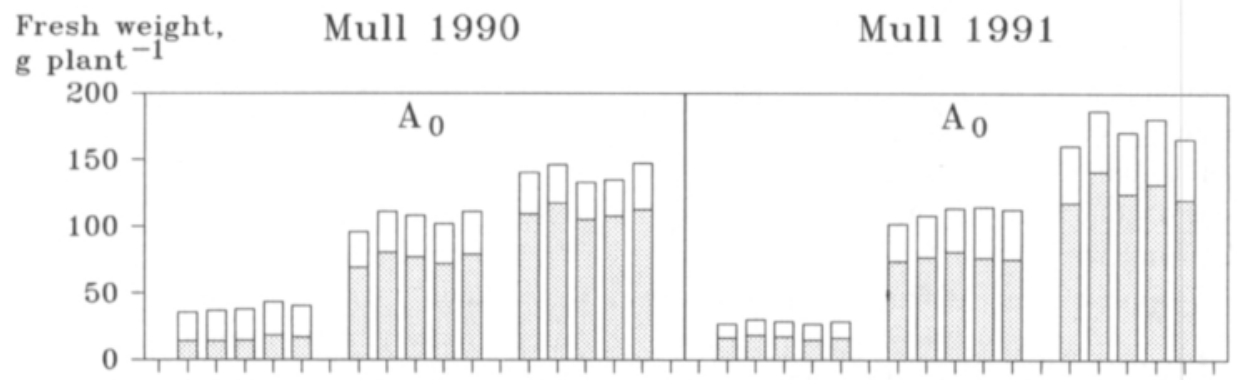

B: $12345-12345-12345-B: 12345-12345-12345-$ Mechanical treatment

DAS 95

129

165

90

121

146

Tap root

Shoot

Fig. 22. Mean shoot and tap root fresh weight $(n=20)$ as affected by soil mechanical treatments $\left(B_{1}-B_{5}\right)$ in fine sand and mull at three sampling times during the growing periods $1990-1991$. DAS $=$ days after sowing. $A_{0}=$ no irrigation, $\mathrm{A}_{1}=$ irrigation. $\mathrm{B}_{1}=$ soil loosening by ridge preparation, $\mathrm{B}_{2}=$ soil loosening by rotary harrowing, $\mathrm{B}_{3}=$ untreated, $\mathrm{B}_{4}=$ one pass of the tractor wheel, $\mathrm{B}_{5}=$ three passes of the tractor wheel.

HSD $_{\text {an }}$ for significant differences:

Tap roots 1990: in fine sand $4 \mathrm{~g}$ (at the same A level $6 \mathrm{~g}$ ) 89 days after sowing (DAS), $21 \mathrm{~g}$ (29 g) 123 DAS, $35 \mathrm{~g}$ (50 g) $158 \mathrm{DAS}$

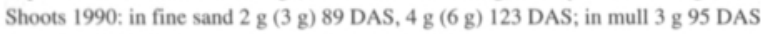

Tap roots 1991: in fine sand $14 \mathrm{~g}(20 \mathrm{~g}) 145$ DAS 


\section{AGRICULTURAL SCIENCE IN FINLAND}

\section{Pietola, L.: Effect of soil compactness on the growth and quality of carrot}

clay soils had a negative effect on tap root growth at the first and second sampling. Later, at harvest (third sampling), soil compaction $\left(\mathrm{B}_{5}\right)$ had a very adverse effect on mean tap root weight, especially under irrigated conditions. In narrow ridges $\left(\mathrm{B}_{1}\right)$, tap root growth was favoured by irrigation. Shoot growth was affected by clay soil mechanical treatments almost like root growth. Under loose clay soil conditions, shoot biomass increased by irrigation, but in compacted clay soil it decreased by water applications. Interaction was statistically significant at the first and second sampling date.

In 1990 in fine sand, tap root fresh weight increased significantly by irrigation (Fig. 22), on average $10 \mathrm{~g}$ and $20 \mathrm{~g}$ after the first and second sampling, respectively. This positive effect of irrigation was found also in shoot weights, differences averaging $8 \mathrm{~g}, 9 \mathrm{~g}$ and $6 \mathrm{~g}$, after the first, second and third sampling, respectively. Comparison of tap root weights between loose and compacted fine sand indicates a statistically significant negative effect of soil compaction on root fresh weight at all sampling times. Shoot development was also adversely affected by soil compaction, but to a smaller extent and only at the first and second sampling dates.

The late applications of water to fine sand in 1991 did not have any influence on carrot root weight, but shoot growth was still affected (Fig. $22)$. At the second sampling the average shoot fresh mass was $37 \mathrm{~g}$ without irrigation and $48 \mathrm{~g}$ with water applications. At harvest, the values were $41 \mathrm{~g}$ and $47 \mathrm{~g}$, respectively. The soil mechanical treatments did not affect statistically significantly tap root size until the third sampling. Earlier, at the second sampling, the negative effect of soil compaction $\left(\mathrm{B}_{5}\right)$ was significant only at $\mathrm{P}<0.10$ as compared with $\mathrm{B}_{2}$ treatment.

In mull field, the modifications of biomass accumulation by mechanical treatments were not statistically significant (Fig. 22). Even the great difference in root fresh weight between two loosening treatments $\left(B_{1}=117 \mathrm{~g}\right.$ and $\left.B_{2}=141 \mathrm{~g}\right)$ at the second sampling in 1990 was significant only at $\mathrm{P}<0.10$. However, shoot growth in 1990 showed positive response to soil compaction $\left(\mathrm{B}_{4}\right)$ at the first sampling, when shoot growth was the most retarded in narrow ridges. In 1991, this tendency was measured in August as well when the shoot fresh mass averaged $28 \mathrm{~g}$ and $38 \mathrm{~g}$ in $\mathrm{B}_{1}$ and $\mathrm{B}_{4}$ treatments, respectively $(\mathrm{P}<0.10)$.

\section{Final yield}

Comparison of final carrot root yields per hectare in non-irrigated conditions in all experimental years (Fig. 23) indicates only slight or negligible influence of water applications on carrot production. In fine sand, the mechanical treatments had a slight effect on total yields. In 1989, the highest total yield was achieved by $\mathrm{B}_{2}$ treatment. In 1990 , the highest yield was produced by $\mathrm{B}_{3}$ treatment, but the difference between this yield and yields from $\mathrm{B}_{1}$ and $\mathrm{B}_{5}$ treatments was significant only at $\mathrm{P}<0.10$. The effect of soil mechanical treatments on the yield of medium-size roots (50-250 g, non-split and non-branched) was very similar to the effects on total yields. In 1991, with no drought in early summer, the narrow ridges $\left(B_{1}\right)$ produced the highest yield of medium-size roots.

Similarly to biomass accumulation, the most distinct effect of mechanical treatments on final tap root yield was found in clay soil (Fig. 23). On average, the lowest total yields were measured in both irrigation schemes from loosened $\left(B_{1}\right)$ and compacted $\left(B_{5}\right)$ soils. The total yield of $B_{1}$ treatment increased remarkably $(27 \%)$ by irrigation, whereas irrigations decreased the total yield in compacted clay soil very dramatically $(21 \%)$. This interaction was statistically significant only when yields of all four rows were considered. On the basis of the yield of two inner rows, the interaction was significant only at $11 \%$ level. Comparison of the yield of medium-size roots produced by three times compacted soil $\left(\mathrm{B}_{5}\right)$ and by all other treatments, including $\mathrm{B}_{1}$ plots, shows distinctly the very poor soil conditions of compacted clay soil for carrot production.

In mull, carrot yields were affected by the mechanical treatments only in 1990, when the total yield was reduced remarkably by the $\mathrm{B}_{1}$ 
Vol. 4: 139-237.

Yield, $\mathrm{Mg} \mathrm{ha}^{-1} \quad$ Fine sand 1989

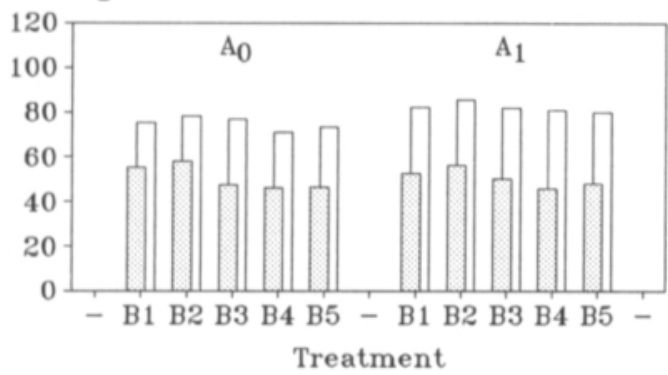

Yield, $\mathrm{Mg} \mathrm{ha}^{-1} \quad$ Fine sand 1990

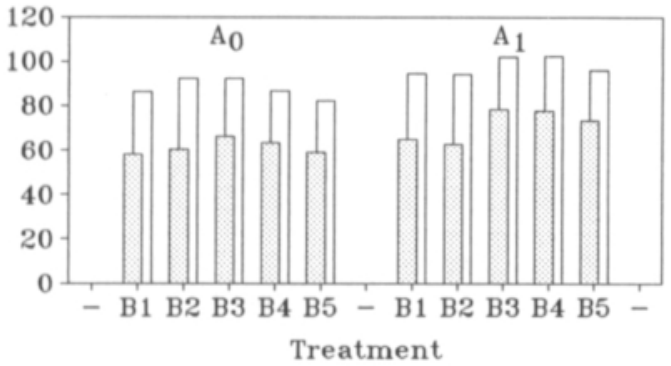

Yield, $\mathrm{Mg} \mathrm{ha}^{-1} \quad$ Fine sand 1991

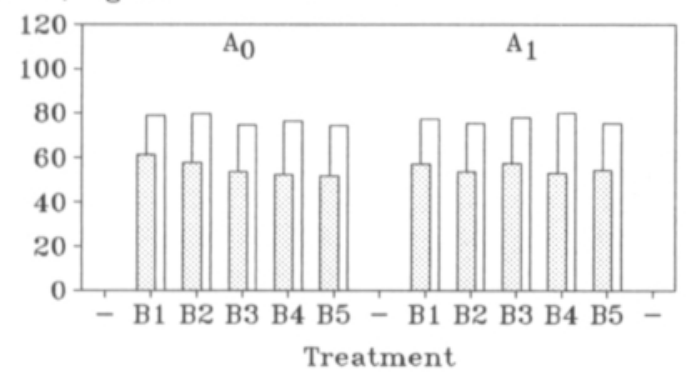

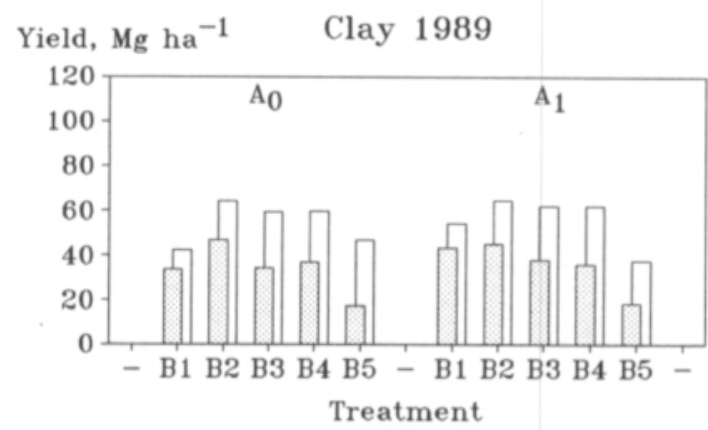

Yield, $\mathrm{Mg} \mathrm{ha}^{-1}$ Mull 1990
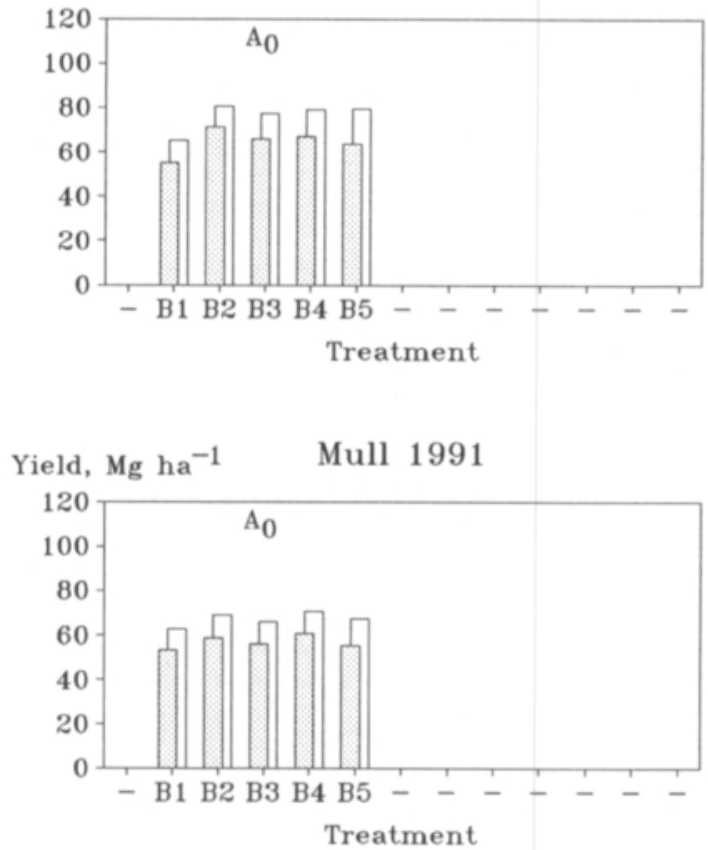

Fig. 23. Yield of tap roots as affected by mechanical treatments $\left(\mathrm{B}_{1}-\mathrm{B}_{5}\right)$ of experimental soils under non-irrigated $\left(\mathrm{A}_{0}\right)$ and irrigated $\left(\mathrm{A}_{1}\right)$ conditions. White columns $=$ total yield, shaded columns $=$ yield of non-split and non-branched roots of 50 $250 \mathrm{~g} . \mathrm{B}_{1}=$ soil loosening by ridge preparation, $\mathrm{B}_{2}=$ soil loosening by rotary harrowing, $\mathrm{B}_{3}=$ untreated, $\mathrm{B}_{4}=$ one pass of the tractor wheel, $\mathrm{B}_{5}=$ three passes of the tractor wheel.

HSD $_{0.0 s}$ for significant differences:

Total yield: in fine sand $7 \mathrm{Mg}$ (at the same A level $8 \mathrm{Mg}$ ) in 1989; in clay $11 \mathrm{Mg}$ (15 Mg); in mull $7.5 \mathrm{Mg}$ in 1990

Yield of non-split and non-branched roots of $50-250 \mathrm{~g}$ : in fine sand $6 \mathrm{Mg}(9 \mathrm{Mg})$ in $1989,12 \mathrm{Mg}(17 \mathrm{Mg})$ in $1990,6 \mathrm{Mg}$ (8 Mg) in 1991 ; in clay $13 \mathrm{Mg}$ (18 Mg)

treatment (Fig. 23). Also the lowest yield of medium-size roots was achieved by $\mathrm{B}_{1}$ treatment, but differences between treatments were not any more statistically significant.
Root size

Among different soil types, roots sizing over $250 \mathrm{~g}$ fresh weight were the most abundant in 


\section{AGRICULTURAL SCIENCE IN FINLAND}

Pietola, L.: Effect of soil compactness on the growth and quality of carrot
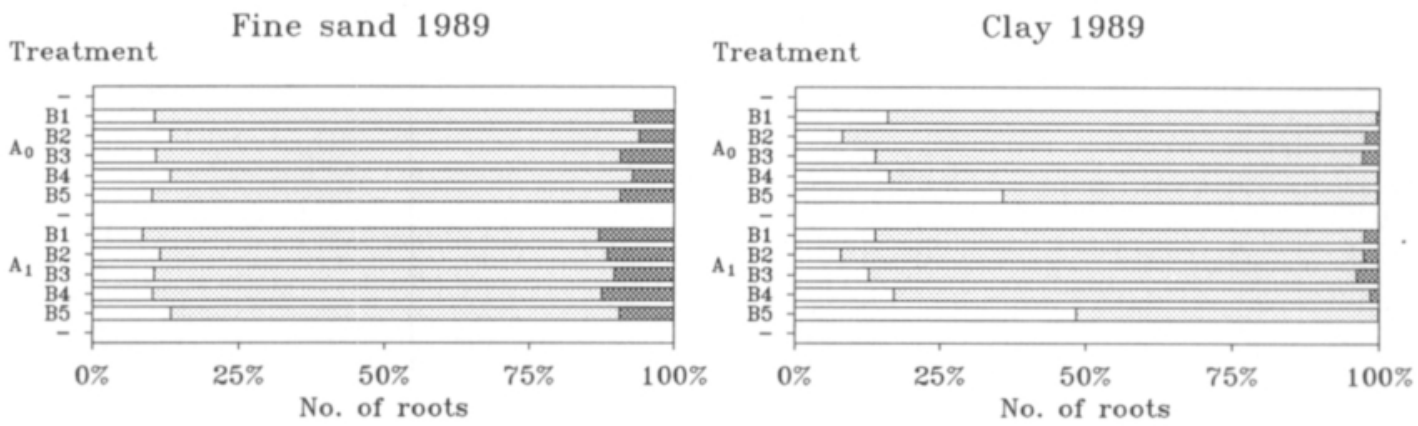

Treatment

Fine sand 1990

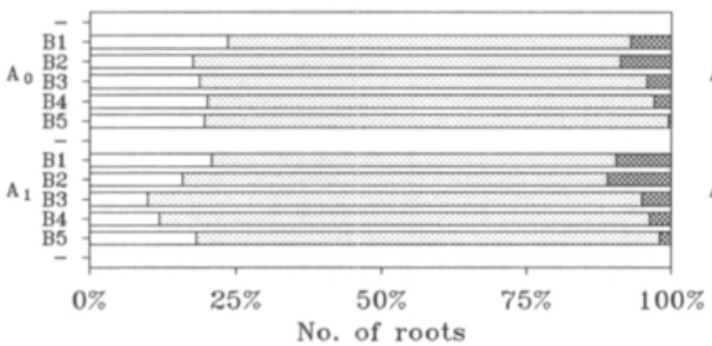

Treatment

Mull 1990

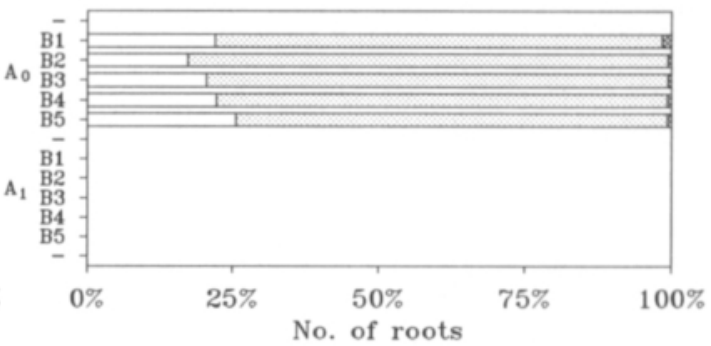

Treatment

Fine sand 1991

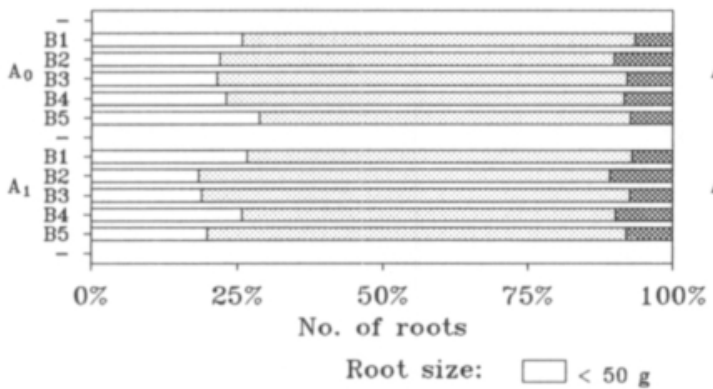

Treatment

Mull 1991

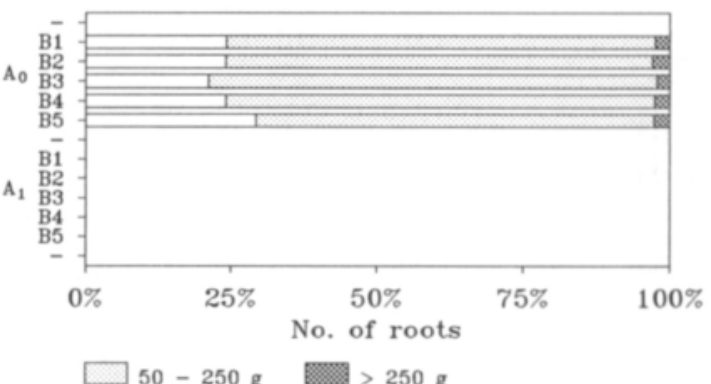

Fig. 24. Tap root size distribution, i.e. population counts in three weight classes from number of non-split tap roots as affected by mechanical treatments $\left(B_{1}-B_{5}\right)$ of experimental soils under non-irrigated $\left(A_{0}\right)$ and irrigated $\left(A_{1}\right)$ conditions. $B_{1}=$ soil loosening by ridge preparation, $\mathrm{B}_{2}=$ soil loosening by rotary harrowing, $\mathrm{B}_{3}=$ untreated, $\mathrm{B}_{4}=$ one pass of the tractor wheel, $\mathrm{B}_{5}=$ three passes of the tractor wheel.

HSD ${ }_{0 \text { os }}$ for significant differences:

$250-\mathrm{g}$ size class: in fine sand $5 \%$ (at the same A level $7 \%$ ) in $1990,3 \%(5 \%)$ in 1991 ; in clay $3 \%(4 \%)$

$50-250-\mathrm{g}$ size class: in fine sand $7 \%(10 \%)$ in 1990 , in clay $13 \%(18 \%)$; in mull $8 \%$ in 1991

$50-\mathrm{g}$ size class: in fine sand $7 \%(10 \%)$ in $1990,5 \%(7 \%)$ in 1991 ; in clay $13 \%(18 \%)$; in mull $8 \%$ in 1991

fine sand (Fig. 24). Irrigation affected root size in fine sand in 1990, decreasing the amount of small roots. Mechanical treatments had a significant influence on the root size distribution in fine sand during 1990-1991. In 1990, the number of too heavy roots was reduced clearly by soil compaction, whereas the number of medium-size roots was significantly lower in loose soils $\left(\mathrm{B}_{1}-\right.$ 
Vol. 4: 139-237.

Deformed roots,

$\%$ from total yield

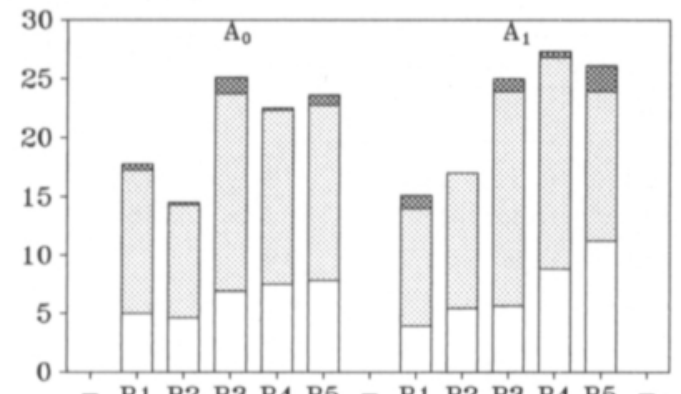

- B1 B2 B3 B4 B5 - B1 B2 B3 B4 B5 Treatment

Deformed roots, $\%$ from total yield

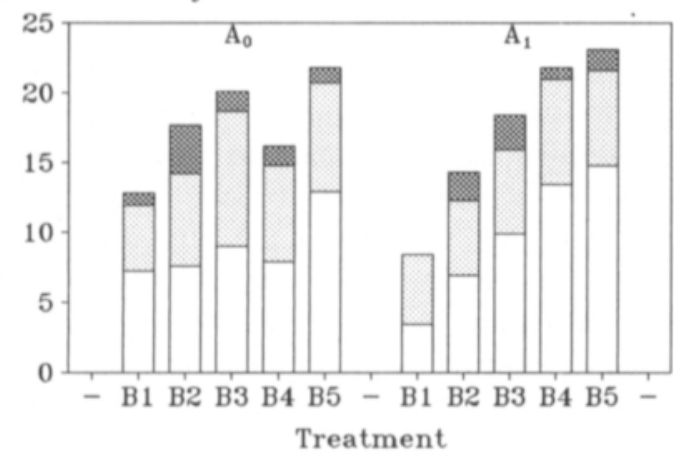

Deformed roots,

$\%$ from total yield

Fine sand 1991

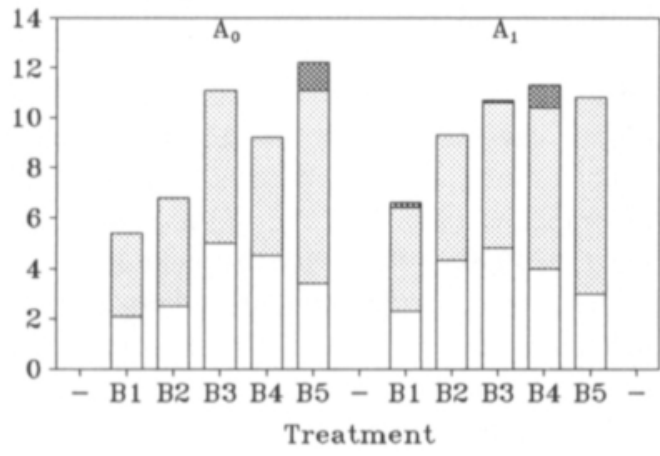

Deformed roots, $\%$ from total yield

Clay 1989

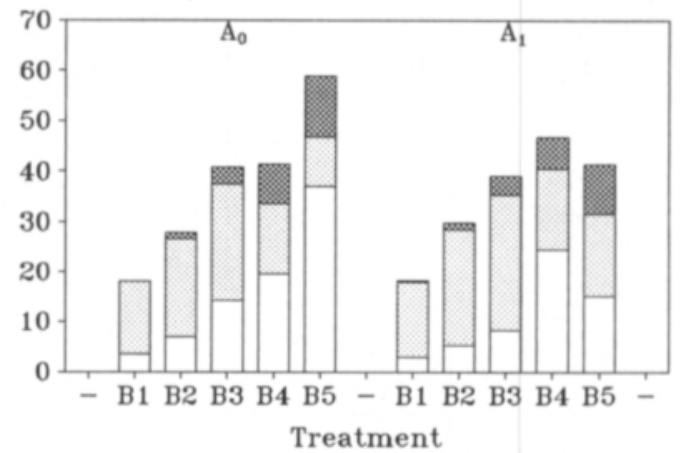

Deformed roots, $\%$ from total yield

Mull 1990

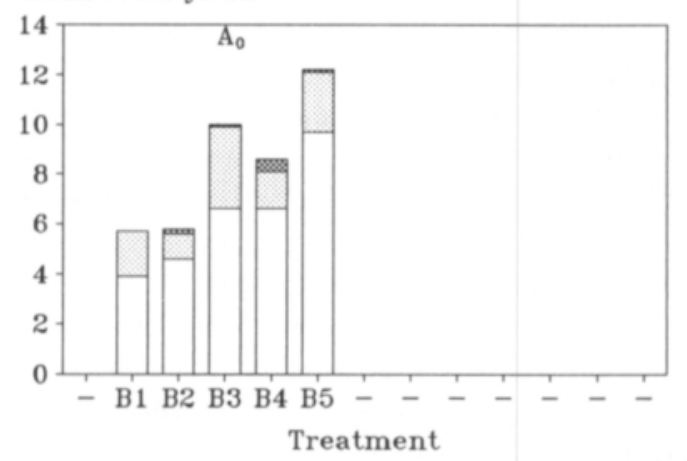

Deformed roots,

$\%$ from total yield

Mull 1991

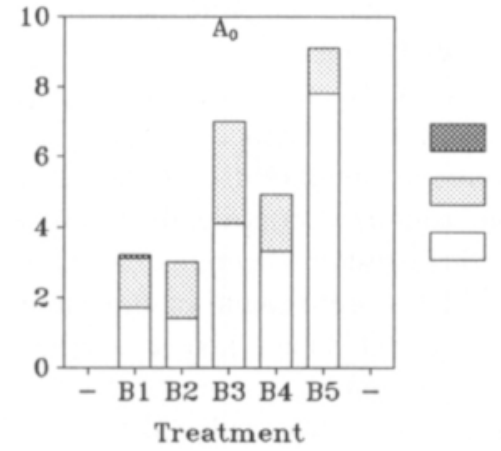

Both

Branched

Split

Fig. 25. Tap root deformity, i.e. gravimetric contents of split, branched and both split and branched roots from total fresh yield as affected by mechanical treatments $\left(B_{1}-B_{5}\right)$ of experimental soils under non-irrigated $\left(A_{0}\right)$ and irrigated $\left(A_{1}\right)$ conditions. $\mathrm{B}_{1}=$ soil loosening by ridge preparation, $\mathrm{B}_{2}=$ soil loosening by rotary harrowing, $\mathrm{B}_{3}=$ untreated, $\mathrm{B}_{4}=$ one pass of the tractor wheel, $\mathrm{B}_{5}=$ three passes of the tractor wheel.

HSD $_{0.05}$ for significant differences:

Split tap roots: in fine sand 3\% (at the same A level 6\%) in 1989, 5\% (7\%) in 1990; in clay 7\% (10\%); in mull $4 \%$ in $1990,6 \%$ in 1991

Branched tap roots: in fine sand $5 \%(6 \%)$ in 1989 ; clay $11 \%(16 \%)$; Both split and branched tap roots: in fine sand $1 \%(2 \%)$ in 1989 ; in clay $5 \%(7 \%)$ 
Pietola, L.: Effect of soil compactness on the growth and quality of carrot

Table 11. Tap root length $(\mathrm{cm})$ of carrots at third sampling of loosened and compacted soils in 1989. $\mathrm{A}_{0}=$ non-irrigated, $\mathrm{A}_{1}=$ irrigated.

\begin{tabular}{|c|c|c|c|c|c|c|c|c|}
\hline \multirow[t]{2}{*}{ Soil } & \multirow[t]{2}{*}{ Irrigation } & \multicolumn{2}{|c|}{ Soil loosening") } & \multicolumn{3}{|c|}{ Tractor wheel passes (n) } & \multirow{2}{*}{$\mathrm{HSD}_{0.05}$} & \multirow[t]{2}{*}{ mean $(\mathrm{A})$} \\
\hline & & 1 & 2 & 0 & 1 & 3 & & \\
\hline \multirow{3}{*}{$\begin{array}{l}\text { Fine } \\
\text { sand }\end{array}$} & $A_{0}$ & 17.3 & 17.0 & 16.1 & 15.5 & 15.4 & 1.2 & 16.2 \\
\hline & $\mathrm{A}_{1}$ & 17.9 & 17.4 & 17.0 & 16.4 & 15.3 & 1.2 & 16.7 \\
\hline & mean & 17.6 & 17.2 & 16.6 & 16.0 & 15.3 & 0.9 & \\
\hline \multirow[t]{3}{*}{ Clay } & $A_{0}$ & 16.6 & 16.6 & 15.8 & 14.5 & 13.3 & 1.7 & 15.4 \\
\hline & $\mathrm{A}_{1}$ & 16.7 & 17.0 & 16.7 & 14.6 & 13.5 & 1.7 & 15.7 \\
\hline & mean & 16.7 & 16.8 & 16.2 & 14.5 & 13.4 & 1.2 & \\
\hline
\end{tabular}

1) 1 = ridge preparation, 2 = rotary harrowing

$\mathrm{B}_{2}$ ) than in other treatments. The number of small roots (below $50 \mathrm{~g}$ ), on the contrary, was the highest in $\mathrm{B}_{1}$ treatment $(22.1 \%)$ and the lowest $(14.3 \%)$ in $B_{3}$ treatment. In 1991, the number of too heavy carrots was lower in $\mathrm{B}_{1}$ than in $\mathrm{B}_{2}$ treatment. For medium-size roots, no statistically significant differences between mechanical treatments were found that year but, like in 1990, small carrots were most abundant in $\mathrm{B}_{1}$ treatment. In 1991, the number of medium-size roots increased by 8 percentage units and the number of small roots decreased by 9 percentage units by the late water applications in three times compacted soil. Interaction was statistically significant.

Irrigation had no effect on root size in clay soil (Fig. 24). Clay soil compaction clearly increased the number of small roots. Similarly, the number of medium-size roots decreased to a great extent by three tractor wheelings. Only few heavy roots $(>250 \mathrm{~g})$ were found in clay field, mainly in $\mathrm{B}_{3}$ treatment. In mull, root size was not affected by mechanical treatments in 1990 , but in 1991 soil compaction reduced to some extent the number of medium-size roots, as compared with $\mathrm{B}_{3}$ treatment.

\section{Root splitting and branching}

Among different soil types, root splitting and branching was most abundant in clay (Fig. 25). On average, splitting decreased by irrigation in clay soil, from $16.2 \%$ to $11.2 \%$. In all soil types, the lowest number of split roots was recorded in loose soils, as soil compaction increased significantly the number of split roots. Only in 1991 did sandy soil compaction not have any significant influence on root splitting. In the treatment of one tractor pass of clay soil, irrigation increased splitting while in three times compacted clay the effect was clearly opposite $(\mathrm{P}<0.001$ for interaction).

Irrigation influenced root branching only in clay soil, where $16 \%$ of total yield was branched without water applications, but as much as $20 \%$ of the yield was branched when irrigated (Fig. 25 ). Soil compaction did not increase the number of branched roots as it affected root splitting. Both in fine sand and clay in 1989, the number of branched roots was the highest in $\mathrm{B}_{3}$ treatment. In 1990 - 1991, when the plant density was higher, mechanical treatments did not affect significantly root branching, although the highest average amount of branched roots was still found in $\mathrm{B}_{3}$ treatment.

The highest number of roots which were both split and branched was found in compacted clay (Fig. 25). Soil compaction increased the amount of split and branched roots also in fine sand in 1991 , with irrigation in $B_{4}$ treatment and without irrigation in $\mathrm{B}_{5}$ treatment. Some tap roots which were damaged at harvest were found in clay soil $(5 \%)$, and less than $3 \%$ in other fields. 
Vol. 4: 139-237.

Length, cm

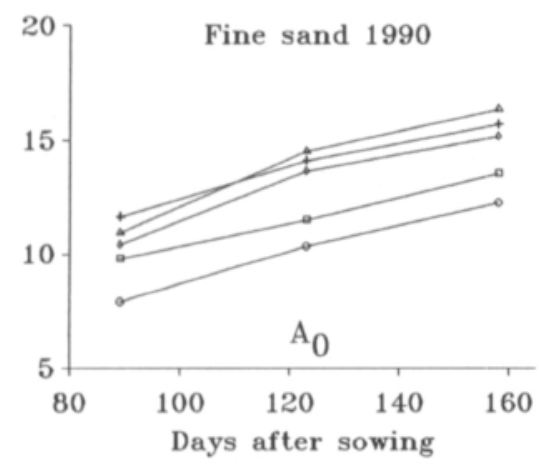

Length, cm

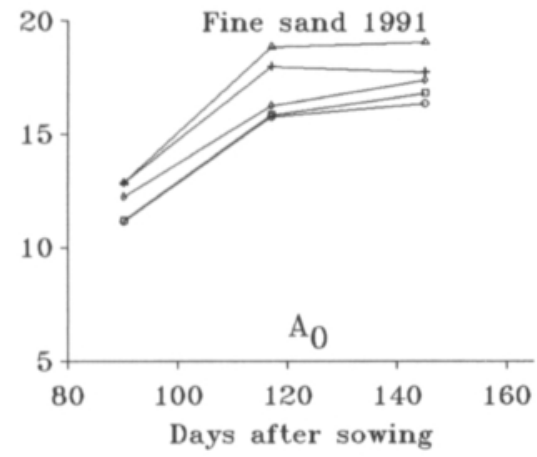

Length, cm

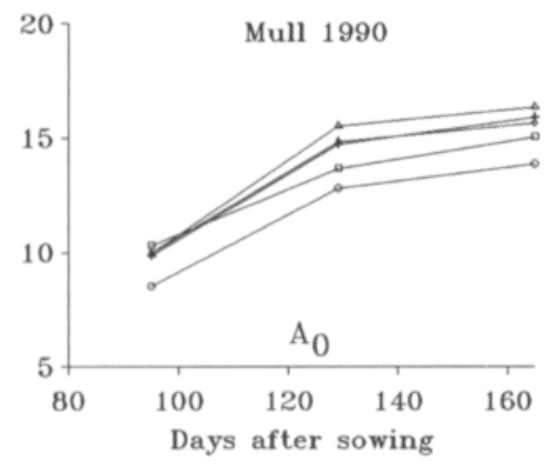

Length, $\mathrm{cm}$

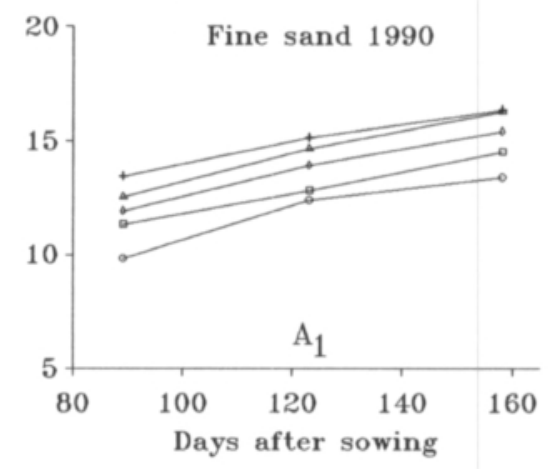

Length, cm

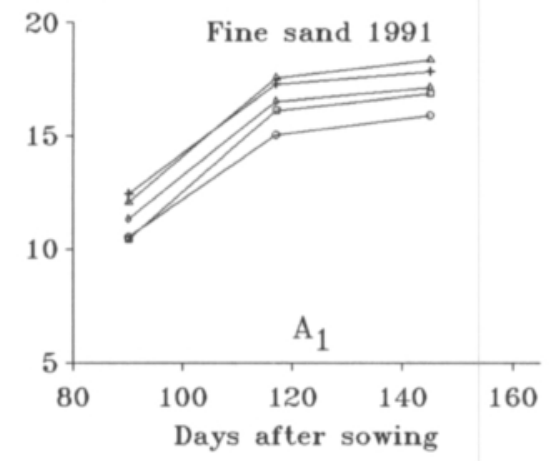

Length, cm

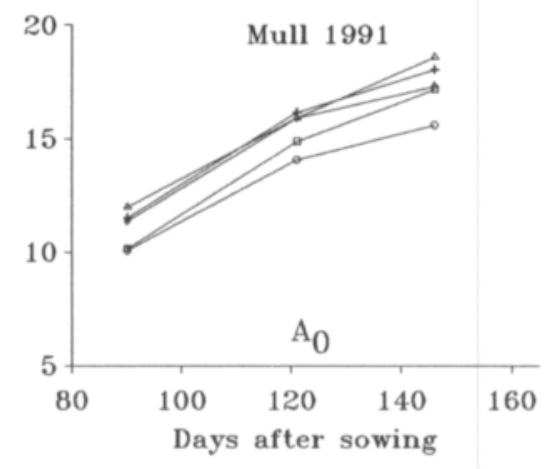

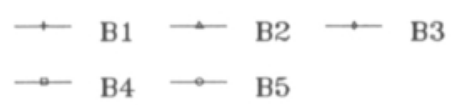

Fig. 26. Tap root length as affected by mechanical treatments $\left(B_{1}-B_{5}\right)$ of mull and fine sand under non-irrigated $\left(A_{0}\right)$ and irrigated $\left(A_{1}\right)$ conditions at three sampling times in 1990-1991. $B_{1}=$ soil loosening by ridge preparation, $B_{2}=$ soil loosening by rotary harrowing, $\mathrm{B}_{3}=$ untreated, $\mathrm{B}_{4}=$ one pass of the tractor wheel, $\mathrm{B}_{5}=$ three passes of the tractor wheel.

$\mathrm{HSD}_{0.05}$ for significant differences:

Fine sand: $0.9 \mathrm{~cm}$ (at the same A level $1.2 \mathrm{~cm}$ ) 89 days after sowing (DAS), $1.4 \mathrm{~cm}(1.9 \mathrm{~cm}) 123$ DAS, $1.3 \mathrm{~cm}(1.8 \mathrm{~cm}) 158$ DAS in 1990; $1.2 \mathrm{~cm}(1.7 \mathrm{~cm}) 90$ DAS, $1.1 \mathrm{~cm}(1.5 \mathrm{~cm}) 117$ DAS, $0.9 \mathrm{~cm}(1.3 \mathrm{~cm}) 145$ DAS in 1991

Mull: $1.7 \mathrm{~cm} 129$ DAS, $1.5 \mathrm{~cm} 165$ DAS in 1990; $1.5 \mathrm{~cm} 90$ DAS, $2.1 \mathrm{~cm} 121$ DAS, $1.3 \mathrm{~cm} 146$ DAS in 1991 
Pietola, L.: Effect of soil compactness on the growth and quality of carrot

Diameter, cm

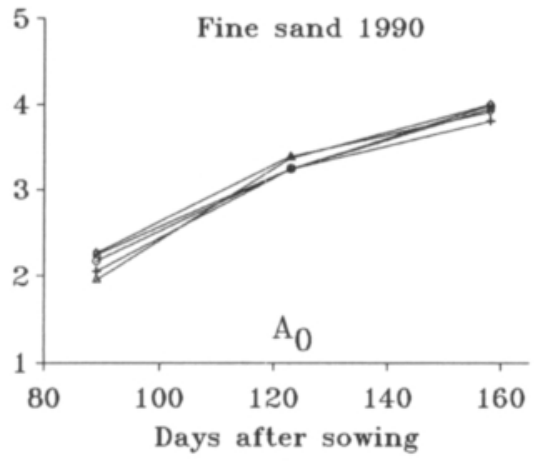

Diameter, cm

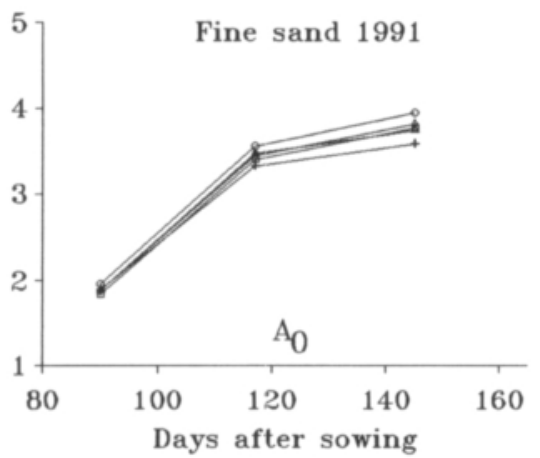

Diameter, cm

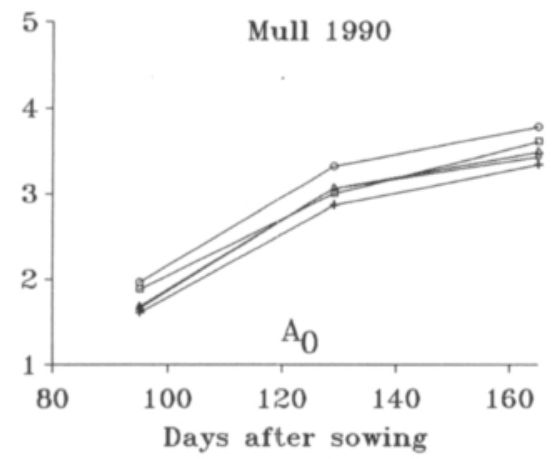

Diameter, cm

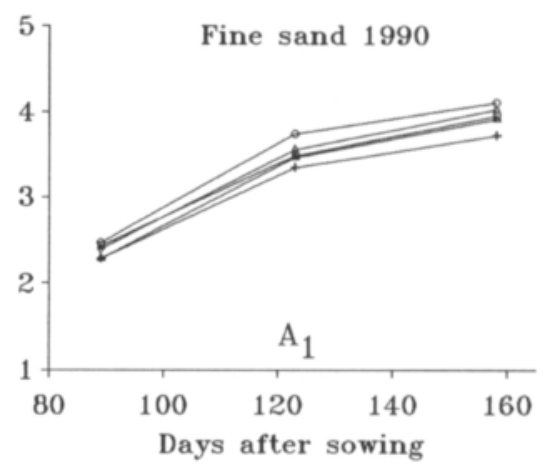

Diameter, cm

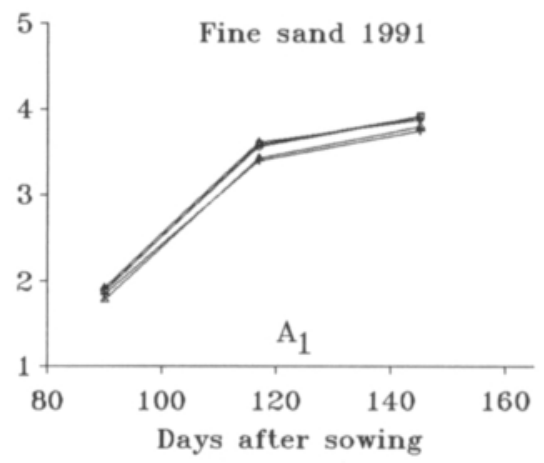

Diameter, cm

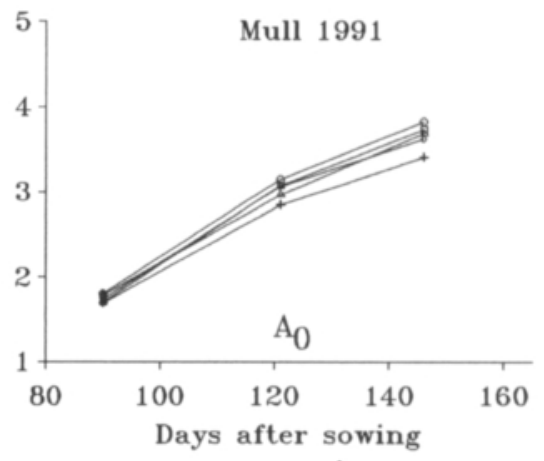

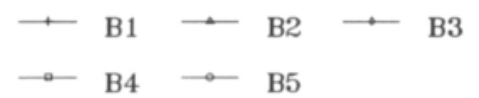

Fig. 27. Tap root maximum diameter as affected by mechanical treatments $\left(B_{1}-B_{5}\right)$ of mull and fine sand under non-irrigated $\left(A_{0}\right)$ and irrigated $\left(A_{1}\right)$ conditions at three sampling times in 1990-1991. $B_{1}=$ soil loosening by ridge preparation, $B_{2}=$ soil loosening by rotary harrowing, $\mathrm{B}_{3}=$ untreated, $\mathrm{B}_{4}=$ one pass of the tractor wheel, $\mathrm{B}_{5}=$ three passes of the tractor wheel.

$\mathrm{HSD}_{0.05}$ for significant differences:

Fine sand: $0.2 \mathrm{~cm}$ (at the same A level $0.2 \mathrm{~cm}) 89$ days after sowing (DAS), $0.2 \mathrm{~cm}(0.3 \mathrm{~cm}) 158$ DAS in $1990 ; 0.1 \mathrm{~cm}(0.1 \mathrm{~cm}) 145 \mathrm{DAS}$ in 1991

Mull: $0.3 \mathrm{~cm} 95$ DAS, $0.3 \mathrm{~cm} 129$ DAS, $0.3 \mathrm{~cm} 165$ DAS in 1990; $0.2 \mathrm{~cm} 146$ DAS in 1991 
Vol. 4: 139-237.

Table 12. Tap root maximum diameter $(\mathrm{cm})$ of carrots at third sampling of loosened and compacted soils in 1989. $A_{0}=$ non-irrigated, $A_{1}=$ irrigated.

\begin{tabular}{|c|c|c|c|c|c|c|c|c|}
\hline \multirow[t]{2}{*}{ Soil } & \multirow[t]{2}{*}{ Irrigation } & \multicolumn{2}{|c|}{ Soil loosening1) } & \multicolumn{3}{|c|}{ Tractor wheel passes (n) } & \multirow[t]{2}{*}{$\mathrm{HSD}_{0.05}$} & \multirow[t]{2}{*}{ mean $(\mathrm{A})$} \\
\hline & & 1 & 2 & 0 & 1 & 3 & & \\
\hline \multirow{3}{*}{$\begin{array}{l}\text { Fine } \\
\text { sand }\end{array}$} & $\mathrm{A}_{0}$ & 4.0 & 4.0 & 4.1 & 4.0 & 4.3 & 0.3 & 4.1 \\
\hline & $A_{1}$ & 4.2 & 4.0 & 4.2 & 4.5 & 4.1 & 0.3 & 4.2 \\
\hline & mean & 4.1 & 4.0 & 4.1 & 4.3 & 4.2 & 0.2 & \\
\hline \multirow[t]{3}{*}{ Clay } & $A_{0}$ & 3.6 & 3.7 & 3.8 & 3.8 & 3.7 & 0.3 & 3.7 \\
\hline & $\mathrm{A}_{1}$ & 3.7 & 3.8 & 3.9 & 4.0 & 3.8 & 0.3 & 3.8 \\
\hline & mean & 3.6 & 3.7 & 3.8 & 3.9 & 3.7 & 0.2 & \\
\hline
\end{tabular}

1) 1 = ridge preparation, 2 = rotary harrowing

\section{Tap root length and diameter}

Irrigation affected differently root length in each experimental year. In 1989, no statistically significant effect was found at harvest either in fine sand or clay soil (Table 11) but in 1990, when root length was measured at three growth stages in fine sand, a significant positive effect of water application was shown at the first sampling in mid-July (Fig. 26). In 1991, on the contrary, tap root length decreased by the late applications of water to fine sand. This negative effect was shown at the first and second sampling, but like in other years, the influence of irrigation on root length disappeared by the harvest time. Tap root length decreased by compaction in all soil types and years.

The measurements in 1990-1991 indicated that during the growing period the maximum diameter of roots was on average slightly higher in irrigated than in non-irrigated plots (Fig. 27). Soil mechanical treatments affected tap root length more than diameter. Only a slight influence of mechanical treatments on root maximum diameter was found in this experiment. The most clear effect was observed in mull where soil compaction increased root diameter by around $0.5 \mathrm{~cm}$ at all three growth stages in 1990. In 1989, roots were thickest at harvest in the treatment of one tractor pass $\left(\mathrm{B}_{4}\right)$ when irrigated, both in fine sand and clay (Table 12). In addition, in fine sand, maximum tap root diameter at harvest decreased by irrigation in $\mathrm{B}_{5}$ treatment, whereas the effect was opposite in $\mathrm{B}_{1}$ plots. The interaction was significant both in 1989 and 1991.

\section{Root shape}

A positive effect of irrigation on the ratio between length and maximum diameter was shown only in fine sand at the first sampling in 1990 (Fig. 28). At the last two samplings in 1991 the role of irrigation was slightly negative. The effect of soil mechanical treatments on root shape was more clear when it was measured as the ratio between length and maximum diameter than as the cylindricality index (Tables 13-14, Figs. 28-29). As compared with compaction, fine sand loosening increased the length to diameter ratio in all three years, while the cylindrical index was increased only at the second sampling in 1991. The cylindrical index was affected by soil compactness only in clay soil, being the smaller the more compacted the soil was (Table 14). In mull, soil compaction decreased the length to maximum diameter ratio at all sampligs (Fig. 28). 
Pietola, L.: Effect of soil compactness on the growth and quality of carrot
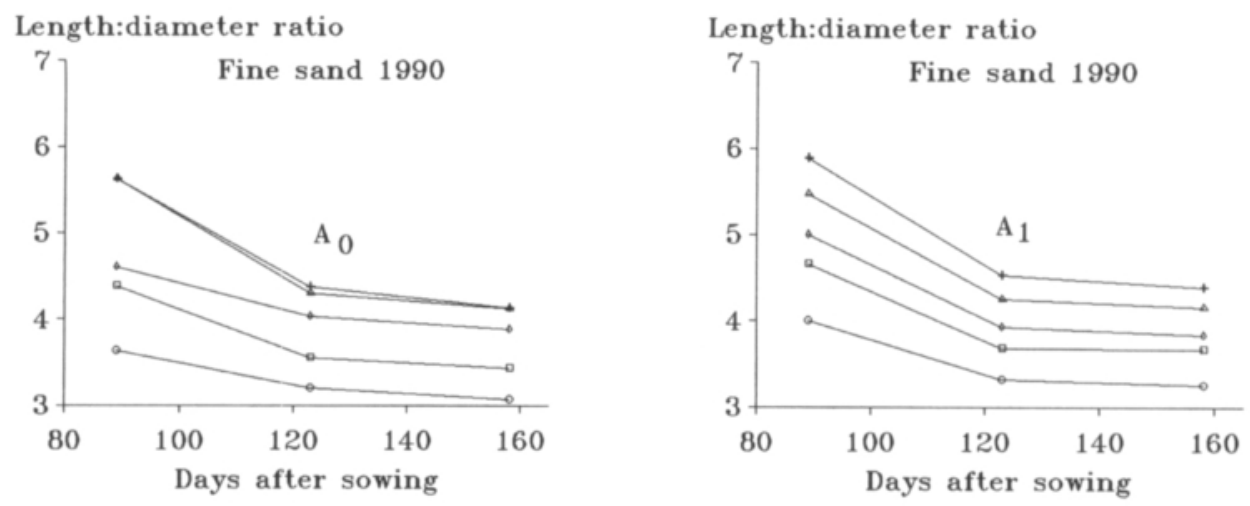

Length:diameter ratio

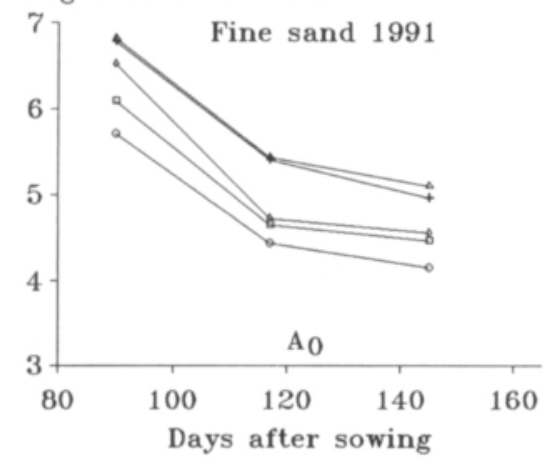

Length:diameter ratio
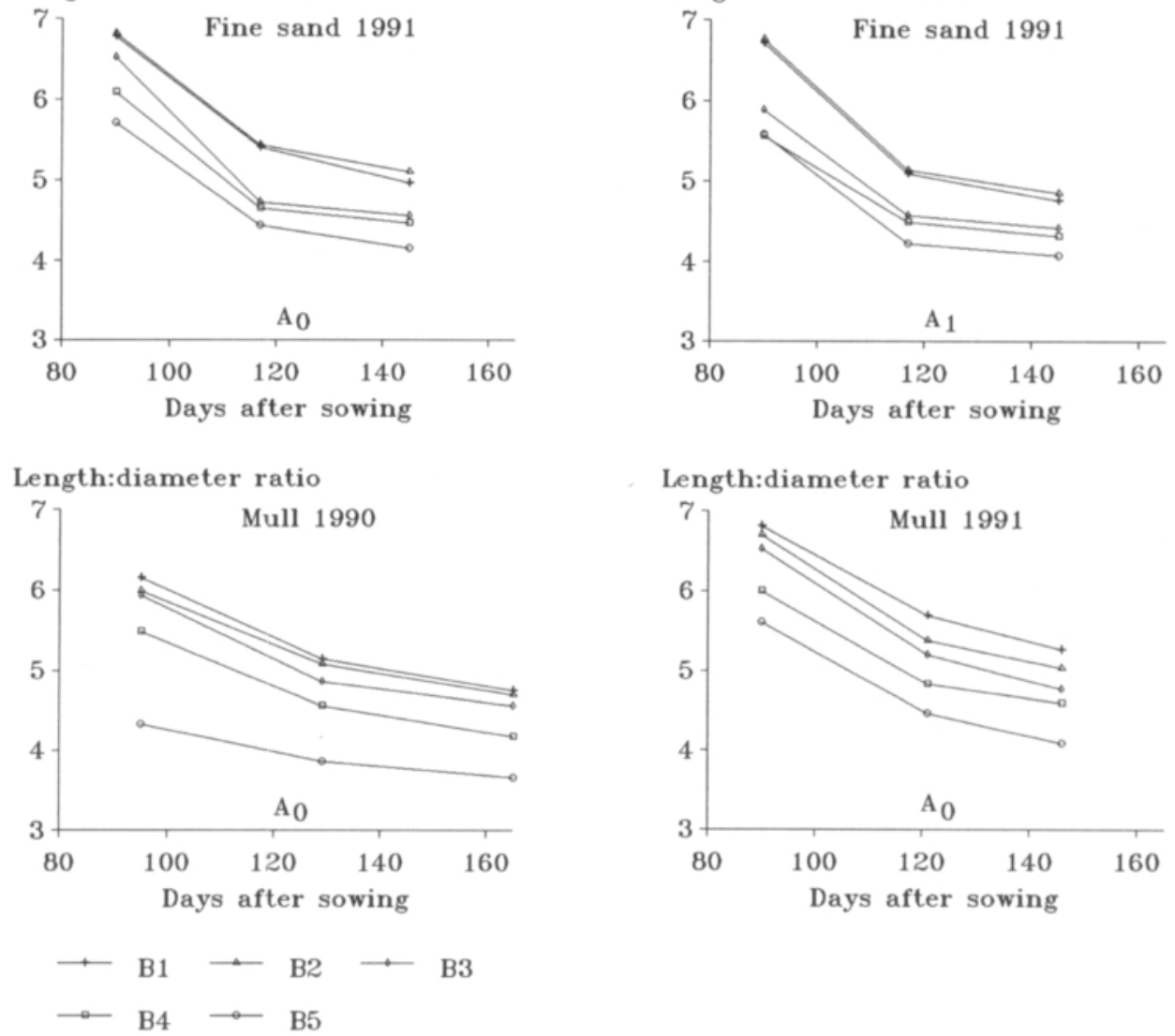

Fig. 28. Tap root length to maximum diameter ratio as affected by mechanical treatments $\left(\mathrm{B}_{1}-\mathrm{B}_{5}\right)$ of mull and fine sand under non-irrigated $\left(A_{0}\right)$ and irrigated $\left(A_{1}\right)$ conditions at three sampling times in 1990-1991. $B_{1}=$ soil loosening by ridge preparation, $\mathrm{B}_{2}=$ soil loosening by rotary harrowing, $\mathrm{B}_{3}=$ untreated, $\mathrm{B}_{4}=$ one pass of the tractor wheel, $\mathrm{B}_{5}=$ three passes of the tractor wheel.

HSD $_{0 \text { os }}$ for significant differences:

Fine sand: 0.4 (at the same A level 0.5) 89 days after sowing (DAS), 0.4 (0.5) 123 DAS, $0.2(0.3 \mathrm{~cm}) 158$ DAS in 1990; 0.5 (0.7) 90 DAS, 0.3 (0.4) 117 DAS, $0.2 \mathrm{~cm}(0.2 \mathrm{~cm}) 145$ DAS in 1991

Mull: 0.8 (95 DAS), 0.6 (129 DAS) and 0.2 (165 DAS) in 1990; 0.8 (90 DAS), 0.5 (121 DAS) and 0.3 (146 DAS) in 1991 
Vol. 4: 139-237.

\section{Cylindrical index}

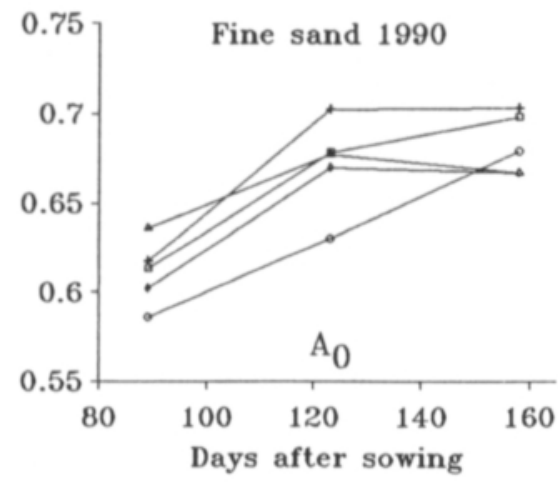

Cylindrical index

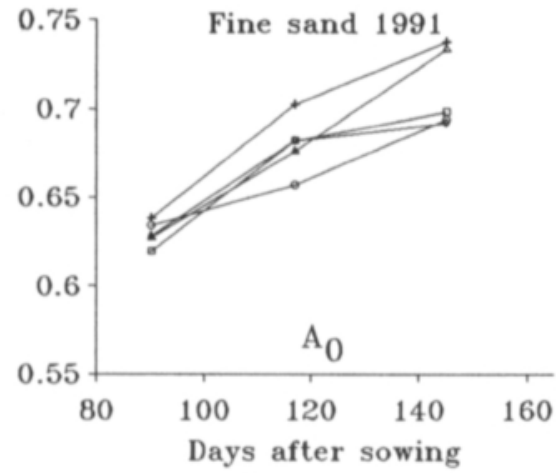

Cylindrical index
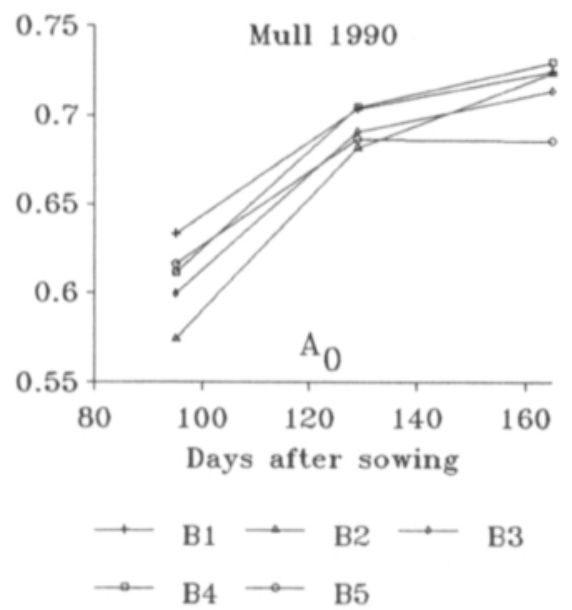

Cylindrical index

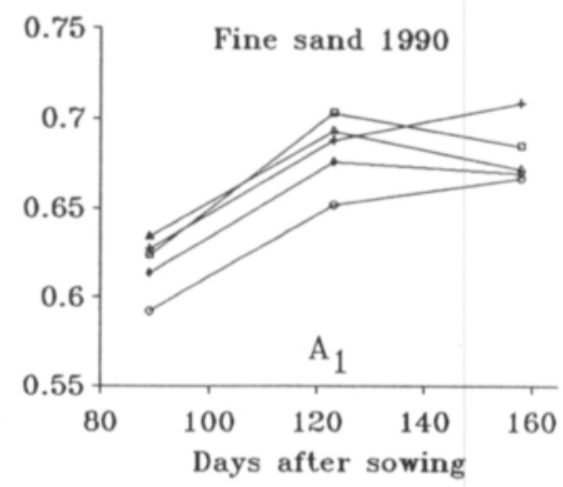

Cylindrical index

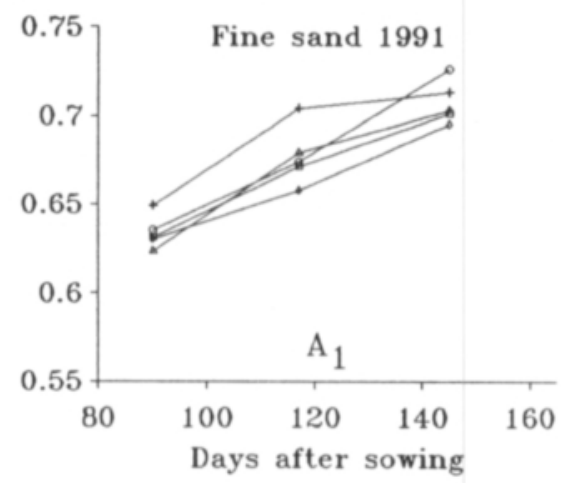

Cylindrical index

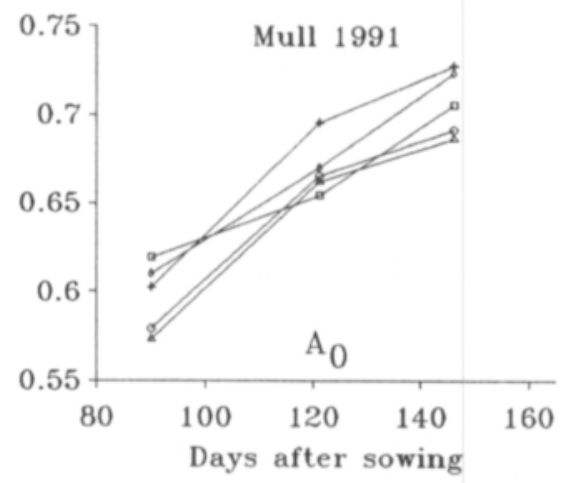

Fig. 29. Tap root cylindrical index as affected by mechanical treatments $\left(B_{1}-B_{5}\right)$ of mull and fine sand under non-irrigated $\left(A_{0}\right)$ and irrigated $\left(A_{1}\right)$ conditions at three sampling times in 1990-1991. $B_{1}=$ soil loosening by ridge preparation, $B_{2}=$ soil loosening by rotary harrowing, $\mathrm{B}_{3}=$ untreated, $\mathrm{B}_{4}=$ one pass of the tractor wheel, $\mathrm{B}_{5}=$ three passes of the tractor wheel. 
Pietola, L.: Effect of soil compactness on the growth and quality of carrot

Table 13. Tap root length to maximum diameter ratio of carrots at third sampling of loosened and compacted soils in 1989. $A_{0}=$ non-irrigated, $A_{1}=$ irrigated.

\begin{tabular}{|c|c|c|c|c|c|c|c|c|}
\hline \multirow[t]{2}{*}{ Soil } & \multirow[t]{2}{*}{ Irrigation } & \multicolumn{2}{|c|}{ Soil loosening1) } & \multicolumn{3}{|c|}{ Tractor wheel passes (n) } & \multirow{2}{*}{$\mathrm{HSD}_{0.05}$} & \multirow[t]{2}{*}{ mean $(\mathrm{A})$} \\
\hline & & 1 & 2 & 0 & 1 & 3 & & \\
\hline \multirow{3}{*}{$\begin{array}{l}\text { Fine } \\
\text { sand }\end{array}$} & $\mathrm{A}_{0}$ & 4.3 & 4.3 & 4.0 & 3.8 & 3.6 & 0.4 & 4.0 \\
\hline & $\mathrm{A}_{1}$ & 4.3 & 4.3 & 4.1 & 3.6 & 3.8 & 0.4 & 4.0 \\
\hline & mean & 4.3 & 4.3 & 4.0 & 3.7 & 3.7 & 0.3 & \\
\hline \multirow[t]{3}{*}{ Clay } & $A_{0}$ & 4.6 & 4.5 & 4.2 & 3.8 & 3.7 & 0.4 & 4.2 \\
\hline & $A_{1}$ & 4.6 & 4.5 & 4.3 & 3.7 & 3.5 & 0.4 & 4.1 \\
\hline & mean & 4.6 & 4.5 & 4.2 & 3.8 & 3.6 & 0.3 & \\
\hline
\end{tabular}

1) 1 = ridge preparation, 2 = rotary harrowing

Table 14. Tap root cylindricality index of carrots at third sampling of loosened and compacted soils in 1989. $A_{0}=$ non-irrigated, $A_{1}=$ irrigated.

\begin{tabular}{|c|c|c|c|c|c|c|c|c|}
\hline \multirow[t]{2}{*}{ Soil } & \multirow[t]{2}{*}{ Irrigation } & \multicolumn{2}{|c|}{ Soil loosening1) } & \multicolumn{3}{|c|}{ Tractor wheel passes (n) } & \multirow[t]{2}{*}{$\mathrm{HSD}_{0.05}$} & \multirow[t]{2}{*}{ mean $(\mathrm{A})$} \\
\hline & & 1 & 2 & 0 & 1 & 3 & & \\
\hline \multirow{3}{*}{$\begin{array}{l}\text { Fine } \\
\text { sand }\end{array}$} & $\mathrm{A}_{0}$ & 0.82 & 0.75 & 0.77 & 0.81 & 0.78 & 0.07 & 0.79 \\
\hline & $A_{1}$ & 0.73 & 0.79 & 0.76 & 0.71 & 0.78 & 0.07 & 0.75 \\
\hline & mean & 0.77 & 0.77 & 0.76 & 0.76 & 0.78 & n.s. ${ }^{2)}$ & \\
\hline \multirow[t]{3}{*}{ Clay } & $\mathrm{A}_{0}$ & 0.73 & 0.78 & 0.75 & 0.67 & 0.59 & 0.09 & 0.70 \\
\hline & $A_{1}$ & 0.76 & 0.78 & 0.71 & 0.64 & 0.59 & 0.09 & 0.69 \\
\hline & mean & 0.75 & 0.78 & 0.73 & 0.65 & 0.59 & 0.06 & \\
\hline
\end{tabular}

1) 1 = ridge preparation, 2 = rotary harrowing

${ }^{2)}$ n.s. = not significant

\subsubsection{Internal quality of tap roots}

\section{Dry matter content}

In fine sand, irrigation decreased dry matter content in tap roots from an average $9.8 \%$ to $8.5 \%$ by water applications at first sampling in 1989 (Fig. 30). In 1990, irrigation decreased the dry matter content at the first sampling at $10 \%$ level. In 1991 , the decrease was 0.4 percentage units. As compared with soil loosening, fine sand compaction increased root dry matter content, as was shown at the first sampling in 1989 , at the third sampling in 1990 and at the second sam- pling in 1991. The interaction between treatments was statistically significant in 1989 because the decrease in dry matter content by irrigation was as high as 2 percentage units in $\mathrm{B}_{3}$ treatment, and much less in other treatments.

Soil mechanical treatments had the most significant effect on root dry matter content in clay soil where it increased clearly with increasing soil compactness at the last two samplings (Fig. 30). At harvest, the interaction between irrigation and mechanical treatments was significant because irrigation increased dry matter content from $9.5 \%$ to $10.1 \%$ in $\mathrm{B}_{3}$ treatment. In other 


\section{AGRICULTURAL SCIENCE IN FINLAND}

Vol. 4: 139-237.

treatments, no influence of irrigation on dry matter content was measured.

Compaction of mull increased root dry matter content, but only at the first sampling in 1990 and at the third sampling in 1991 . The dry matter content was negatively related to soil moisture recorded on plant sampling days in 1991 (gypsum block at $15-\mathrm{cm}$ depth). That year, the growing season in June-July was rainy and autumn was dry $(\mathrm{r}=-0.78 * * *$ for fine sand, $\mathrm{r}=$ $-0.56 * * *$ for mull).

\section{Crude fibre content}

In fine sand, the only statistically significant effect of irrigation or soil mechanical treatments on crude fibre content (firmness) was measured in 1989 at the first sampling, when the average crude fibre content was 1 percentage unit lower in irrigated than in non-irrigated plots (Fig. 31). The interaction was significant because the decreasing effect of irrigation was the most powerful in $\mathrm{B}_{3}$ treatment ( 1.5 percentage units).

Irrigation of clay soil had no effect on the accumulation of crude fibre on average (Fig. 31). Clay soil mechanical treatments had, however, the most remarkable influence on this quality factor. The increasing effect of clay soil compaction on crude fibre content persisted throughout the growing season. A statistically significant interaction between treatments was found at the second sampling, as the crude fibre content was 0.6 percentage units higer in three times compacted and irrigated soil than in non-irrigated soil. At the same time, the crude fibre content decreased slightly by irrigations in other treatments.

In mull, the crude fibre content at the third sampling in 1991 increased with increasing number of tractor passes (Fig. 31). In August 1991, there was some evidence of an increasing effect of mull compaction on crude fibre content $(\mathrm{P}<0.10)$.

The crude fibre content was positively dependent on soil moisture recorded on plant sampling days (gypsum block at $15-\mathrm{cm}$ depth, representing the approximate soil moisture status of the past ten days) in clay soil $\left(\mathrm{r}=0.46^{* *}\right)$, as the less close correlation was determined in fine sand in $1991(\mathrm{r}=-0.37 * * *)$.

\section{Juice content}

Irrigation of fine sand increased $(\mathrm{P}<0.001)$ the juice content of carrots at the first sampling in 1989, while root dry matter content decreased (Fig. 32). Compaction of fine sand did not affect the juiciness of tap roots. In clay, the juice content decreased with increasing clay soil compactness during the whole growing period of 1989. Irrigation had a strong influence on juice content at the second sampling, as in irrigated and three times compacted plots the roots contained around 2 percentage units less juice than without irrigation. The interaction was significant, as in other mechanical treatments the effect of irrigation was positive.

In mull, no statistically significant differences were found until at the third sampling in 1991, when root juiciness decreased with increasing number of tractor wheelings (Fig. 32). The juice content was positively dependent on soil moisture on plant sampling days (gypsum block at $15-\mathrm{cm}$ depth, representing the approximate soil moisture status of the past ten days) in mull soil ( $r=0.33 *$ for $1990, r=0.42 * *$ for 1991), but only slightly, and at $\mathrm{P}<0.10$ in clay soil $(\mathrm{r}=$ 0.22 ). In fine sand, no significant correlation was observed.

\section{Juice dry matter content}

In fine sand, the content of juice dry matter (mainly sugar) decreased at the first sampling in 1989 by 1 percentage unit as a result of irrigation (Fig. 33). The same statistically significant effect was found also in 1990 at the first sampling, although the difference between two irrigation schemes was only 0.5 percentage units. The same effect continued in 1991, as the juice dry matter content at the third sampling was still slightly lower in irrigated than in non-irrigated plots. At this sampling, sandy soil compaction $\left(B_{5}\right)$ increased juice dry matter content. This ef- 
Pietola, L.: Effect of soil compactness on the growth and quality of carrot

Dry matter, \%

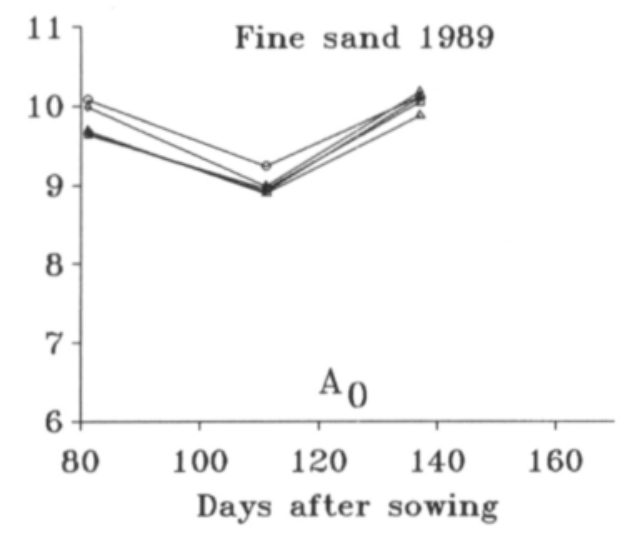

Dry matter, \%

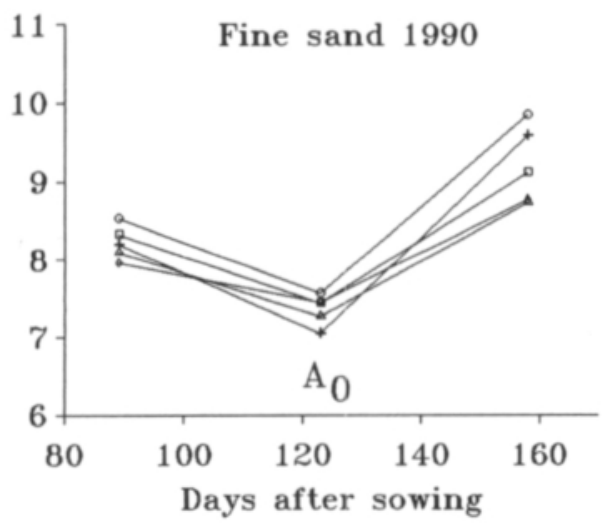

Dry matter, \%

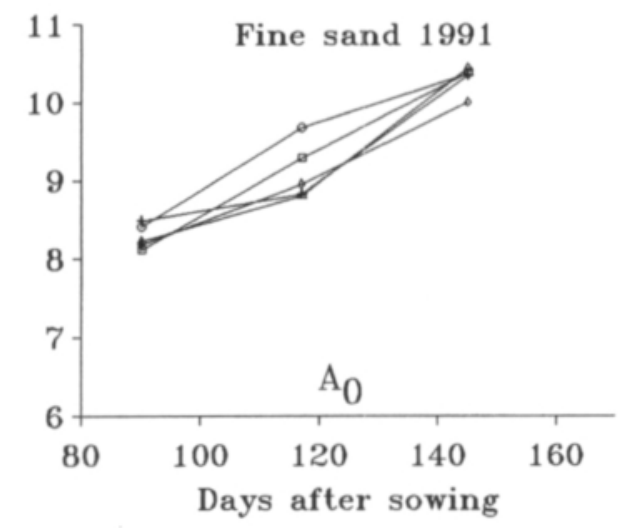

$\longrightarrow$ B1 $\rightarrow$ B2 $\rightarrow$ B3
Dry matter, \%

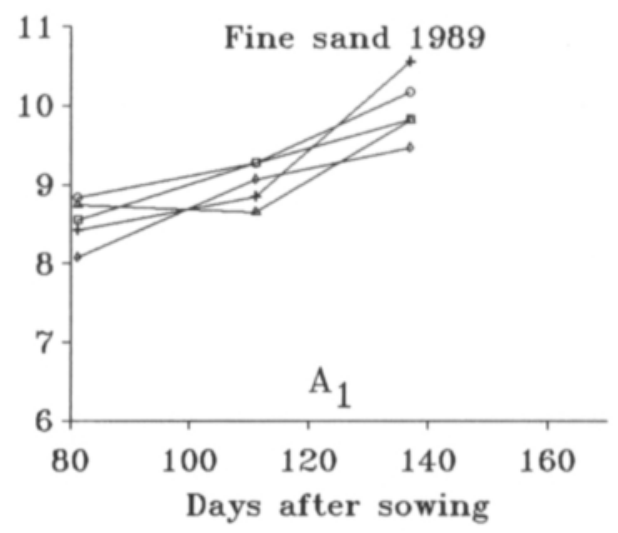

Dry matter, \%

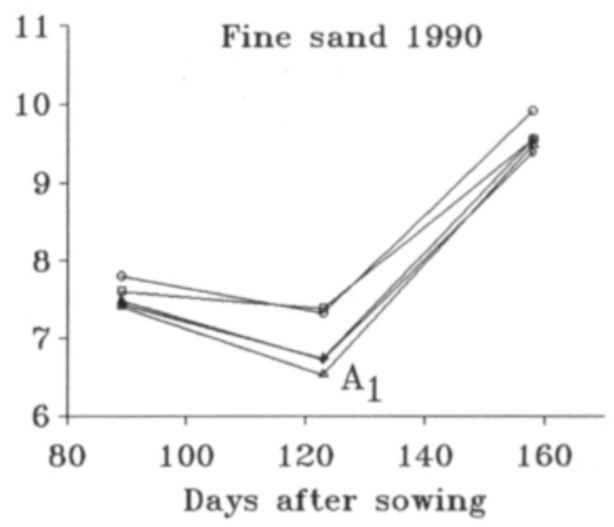

Dry matter, \%

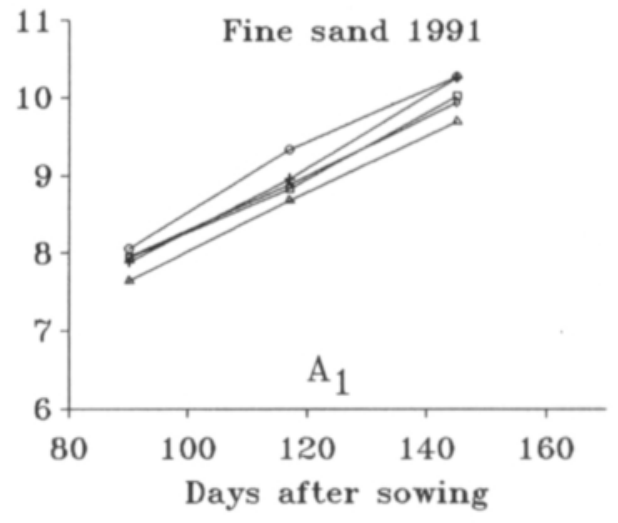


Vol. 4: 139-237.

Dry matter, \%

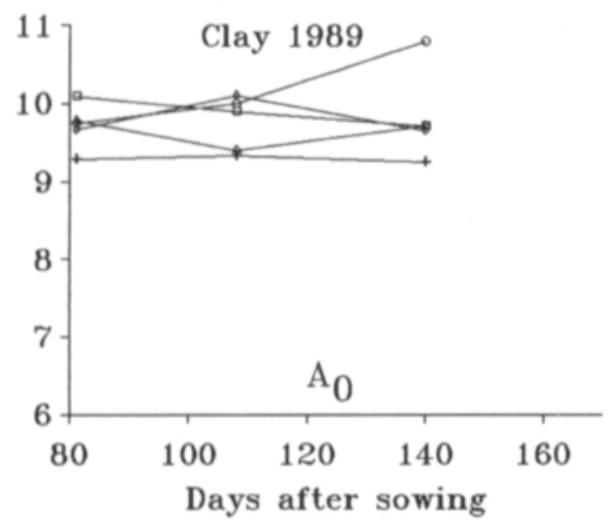

Dry matter, \%

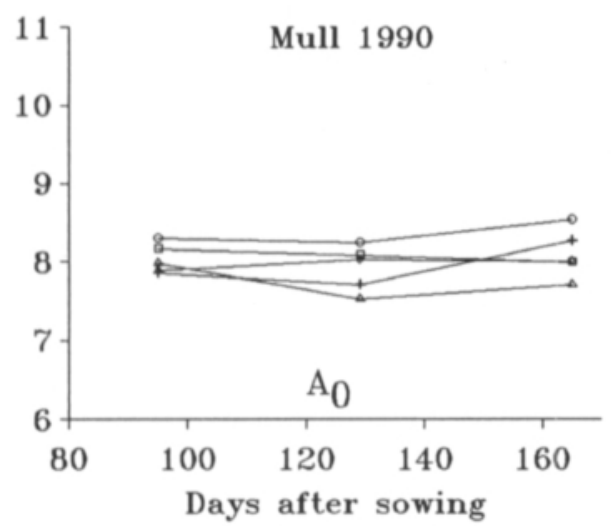

Dry matter, \%

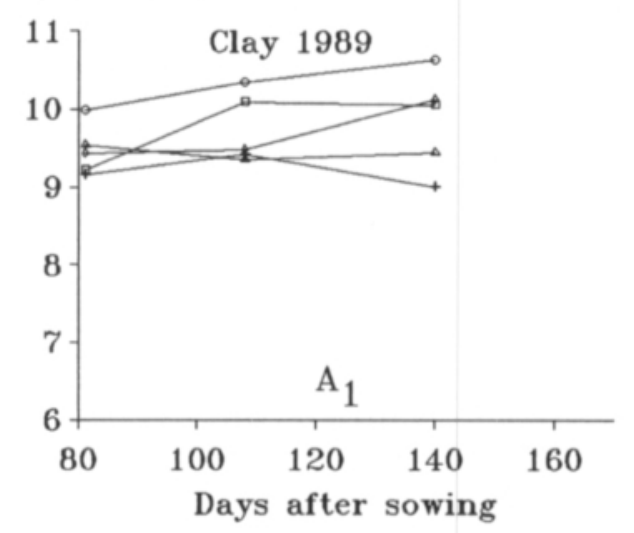

Dry matter, \%

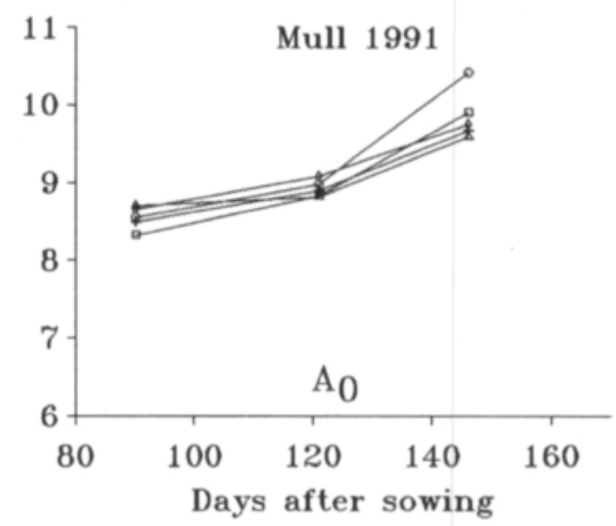

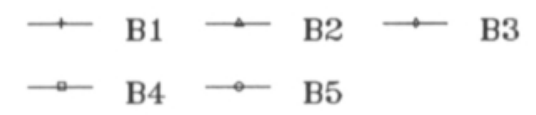

Fig. 30. Tap root dry matter content as affected by mechanical treatments $\left(B_{1}-B_{5}\right)$ of mull and fine sand and clay under nonirrigated $\left(A_{0}\right)$ and irrigated $\left(A_{1}\right)$ conditions at three sampling times in 1989-1991. $B_{1}=$ soil loosening by ridge preparation, $\mathrm{B}_{2}=$ soil loosening by rotary harrowing, $\mathrm{B}_{3}=$ untreated, $\mathrm{B}_{4}=$ one pass of the tractor wheel, $\mathrm{B}_{5}=$ three passes of the tractor wheel.

$\mathrm{HSD}_{\mathrm{eas}}$ for significant differences:

Fine sand: $0.4 \%$ (at the same A level 0.6\%) 80 days after sowing (DAS) in 1989; $0.6 \%(0.8 \%)$ 158 DAS in 1990; $0.7 \%(0.9 \%) 117$ DAS in 1991

Clay: $0.4 \%(0.6 \%) 108$ DAS, $1.1 \%(1.6 \%) 140$ DAS

Mull: $0.5 \% 95$ DAS in 1990; 0.6\% 146 DAS in 1991 
Pietola, L.: Effect of soil compactness on the growth and quality of carrot

Crude fibre,

$\%$ in fresh weight

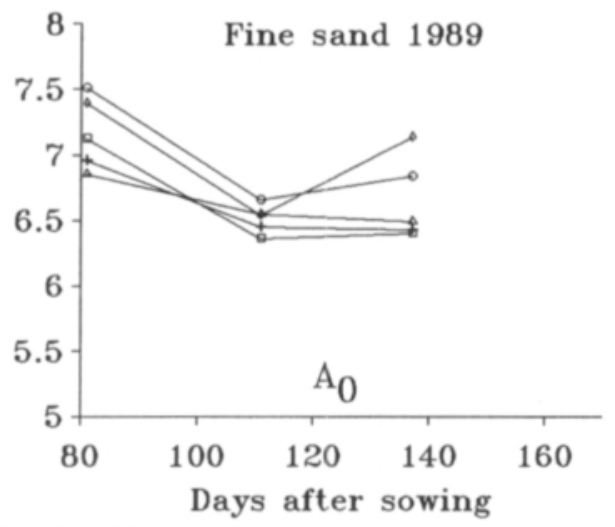

Crude fibre,

$\%$ in fresh weight

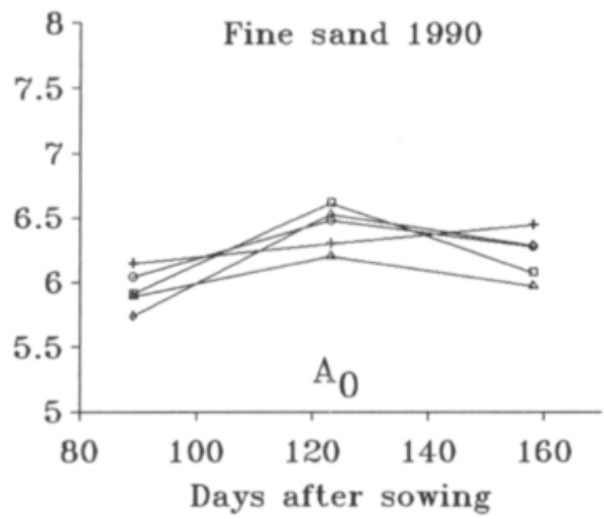

Crude fibre,

$\%$ in fresh weight

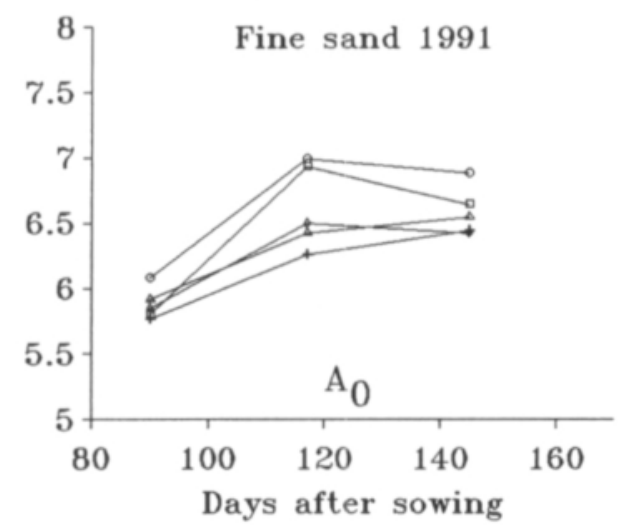

Crude fibre,

$\%$ in fresh weight

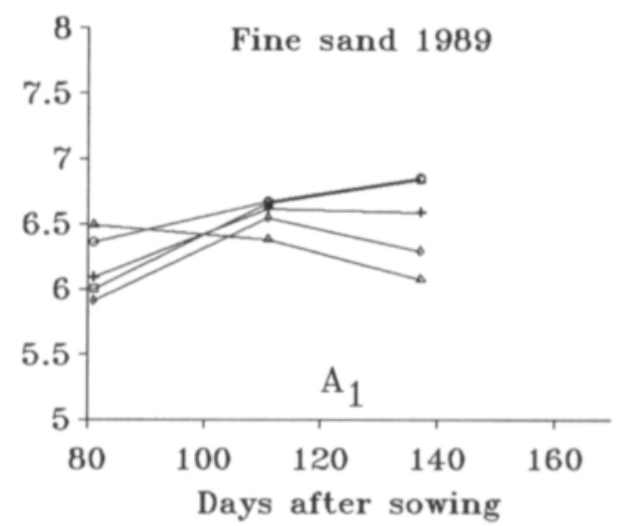

Crude fibre,

$\%$ in fresh weight

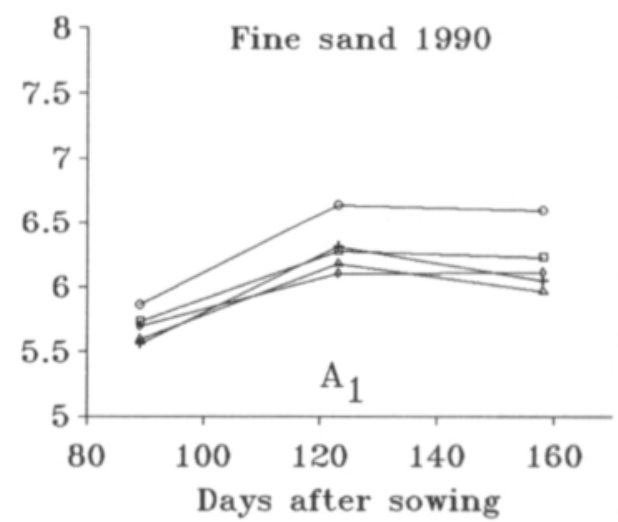

Crude fibre,

$\%$ in fresh weight

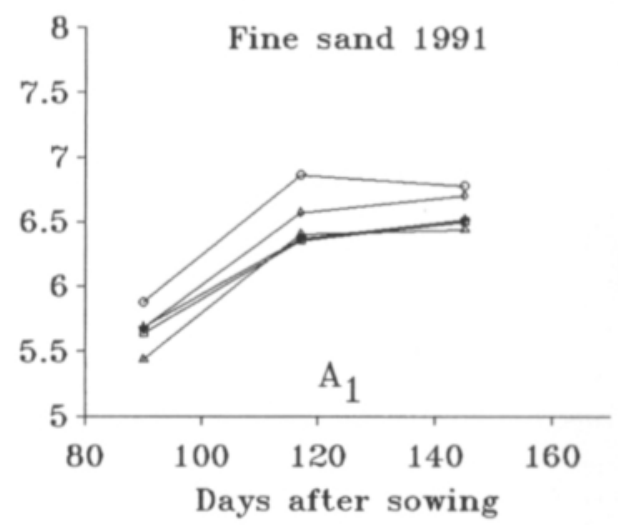

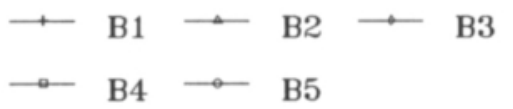




\section{AGRICULTURAL SCIENCE IN FINLAND}

Vol. 4: 139-237.

Crude fibre,

$\%$ in fresh weight

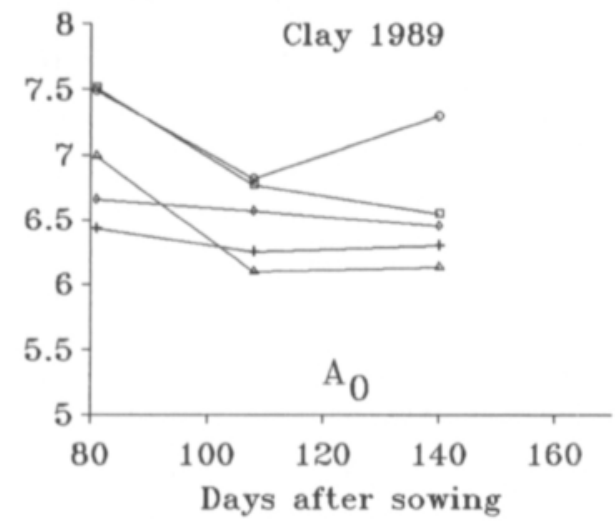

Crude fibre,

$\%$ in fresh weight

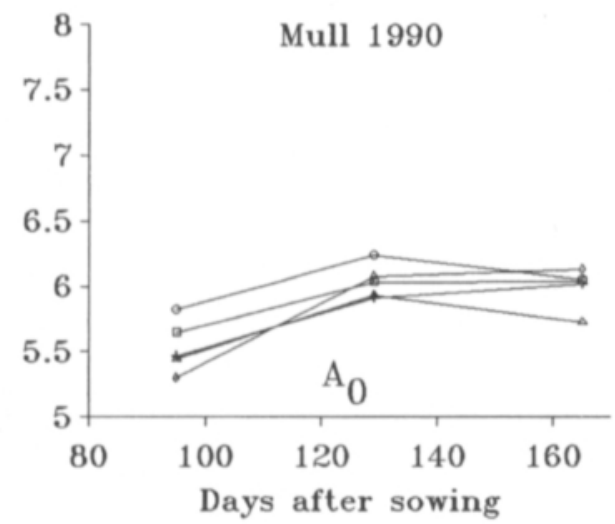

Crude fibre, $\%$ in fresh weight

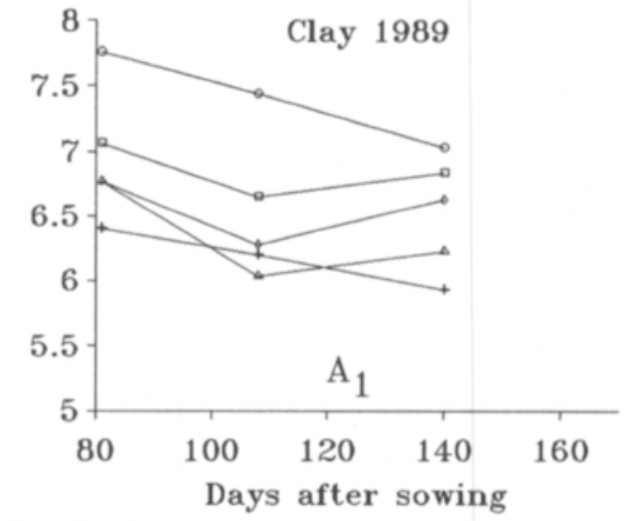

Crude fibre,

$\%$ in fresh weight

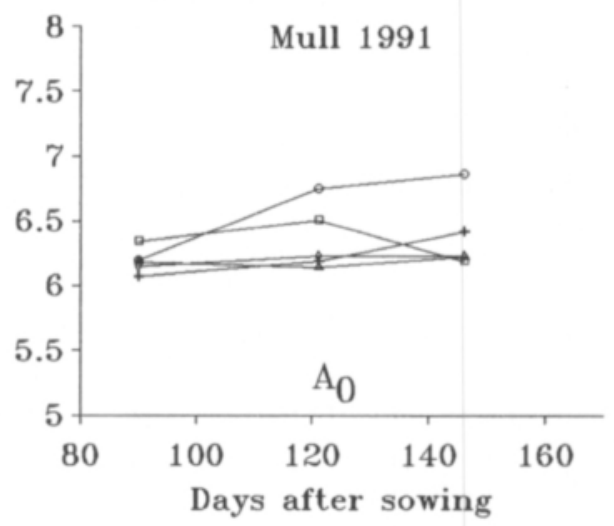

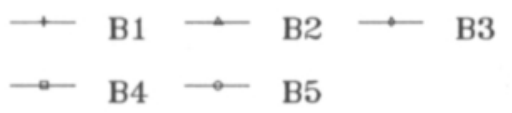

Fig. 31. Tap root crude fibre content as affected by mechanical treatments $\left(B_{1}-B_{5}\right)$ of mull, fine sand and clay under nonirrigated $\left(A_{0}\right)$ and irrigated $\left(A_{1}\right)$ conditions at three sampling times in 1989-1991. $B_{1}=$ soil loosening by ridge preparation, $\mathrm{B}_{2}=$ soil loosening by rotary harrowing, $\mathrm{B}_{3}=$ untreated, $\mathrm{B}_{4}=$ one pass of the tractor wheel, $\mathrm{B}_{5}=$ three passes of the tractor wheel.

HSD $_{0 \text { s }}$ for significant differences:

Clay: $0.7 \%$ (at the same A level $0.7 \%$ ) 81 days after sowing (DAS), $0.3 \%(0.4 \%) 108$ DAS, $0.7 \%(1.0 \%)$ 140 DAS

Mull: $0.7 \% 146$ DAS in 1991 
Pietola, L.: Effect of soil compactness on the growth and quality of carrot
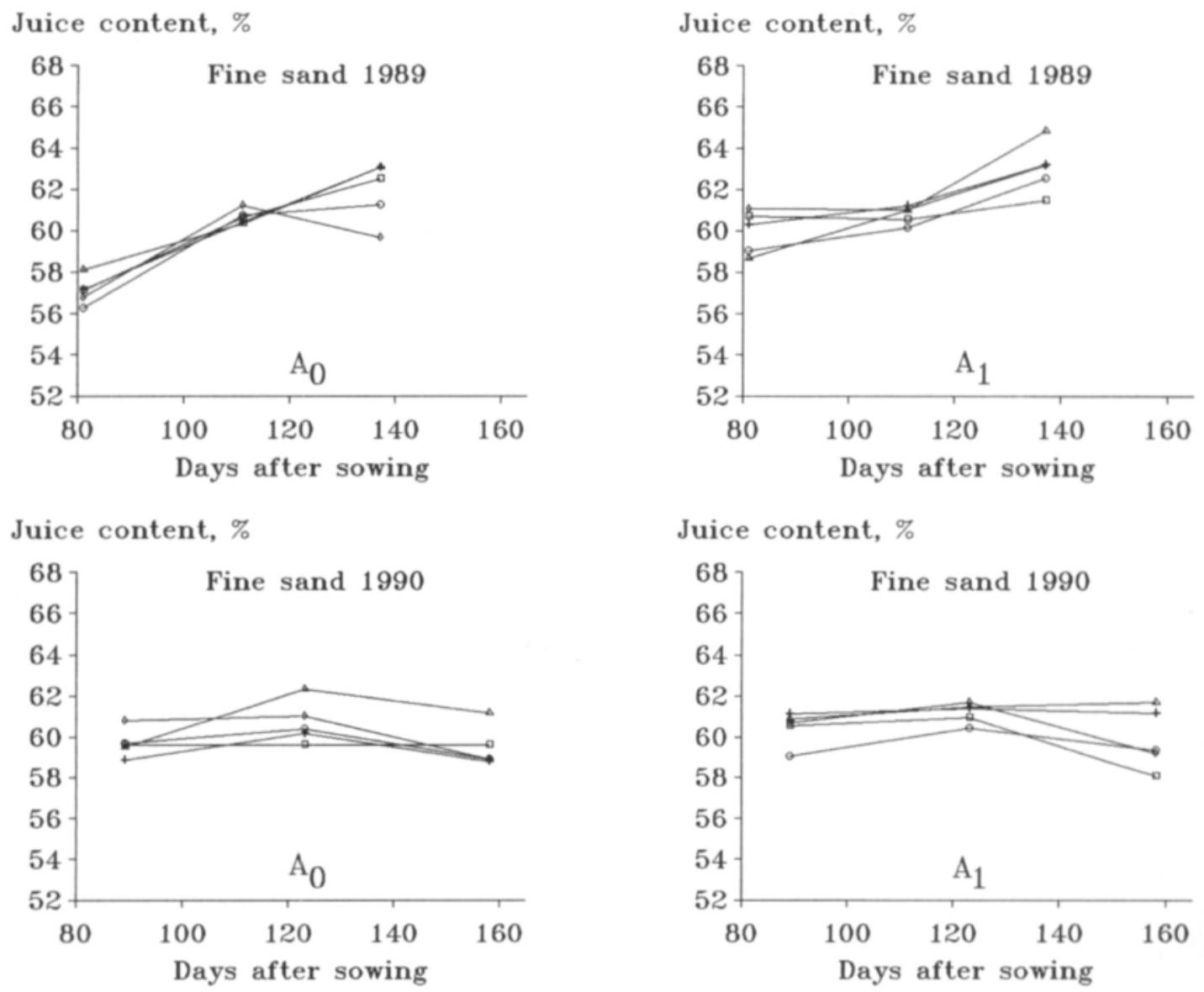

Juice content, \%

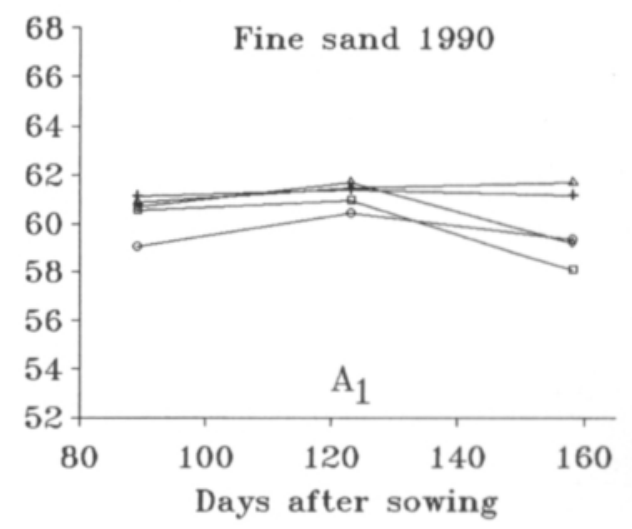

Juice content, \%

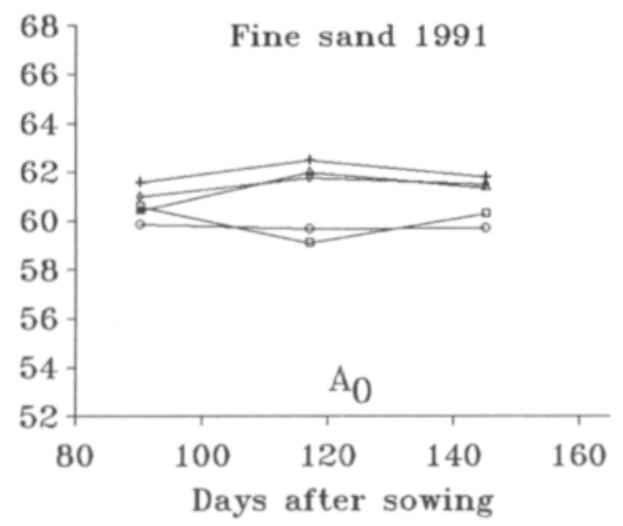

Juice content, \%
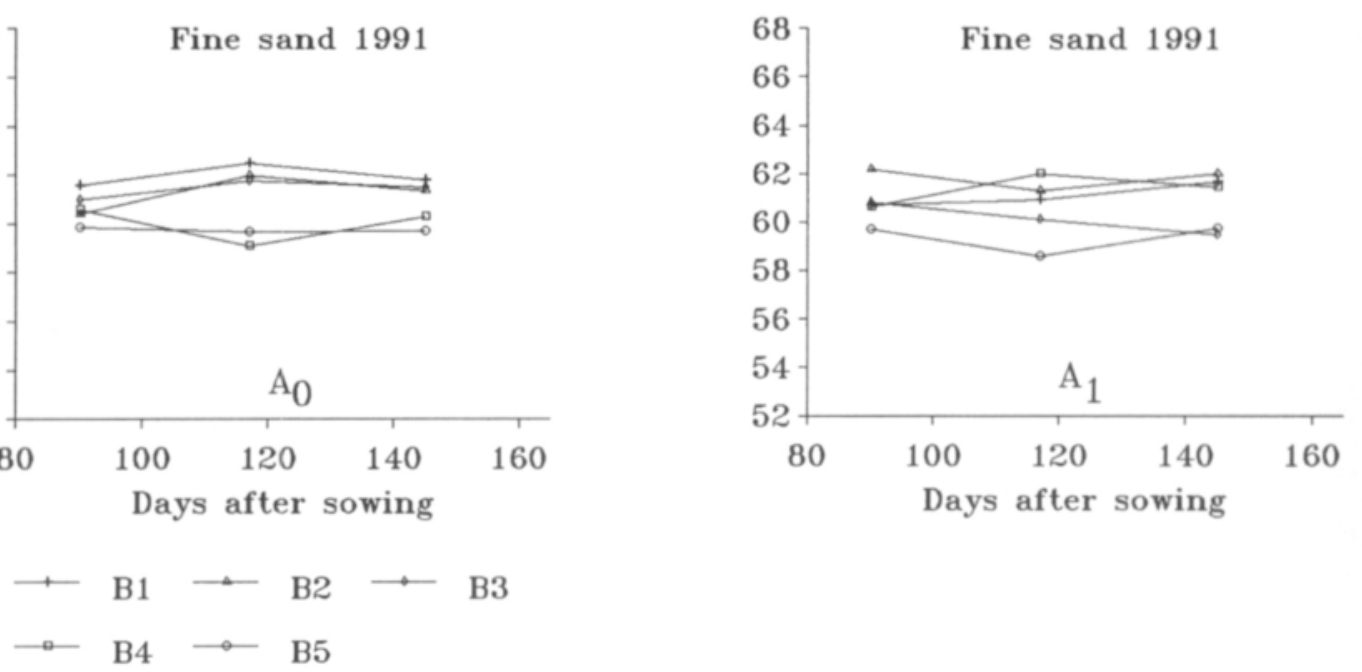


\section{AGRICULTURAL SCIENCE IN FINLAND}

Vol. 4: 139-237.

- Juice content, \%

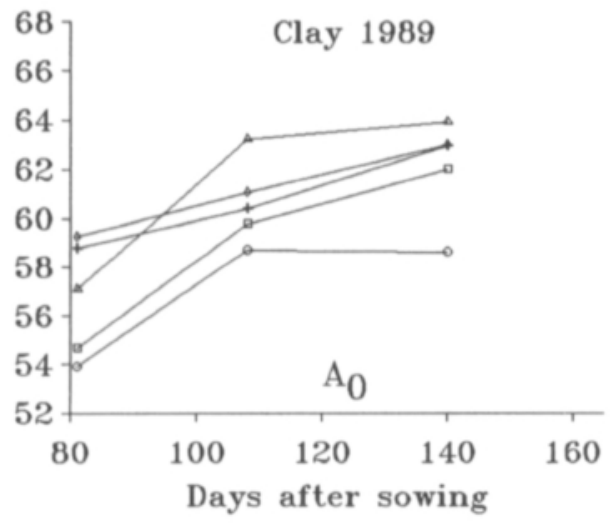

Juice content, \%
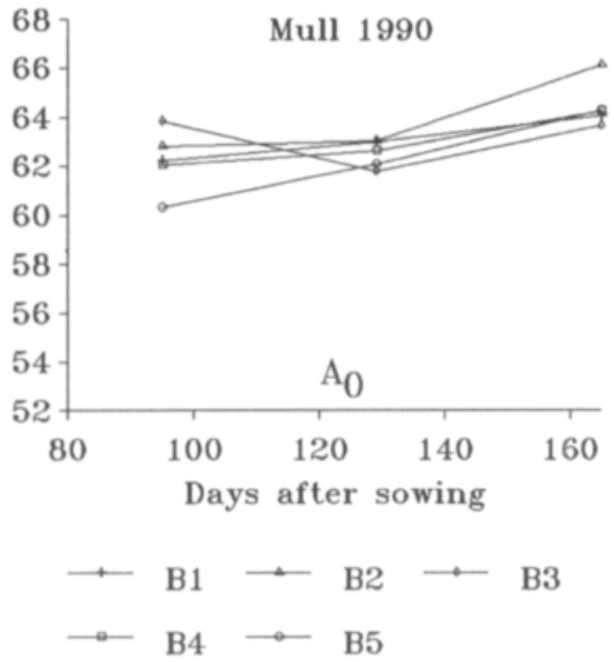

Juice content, \%

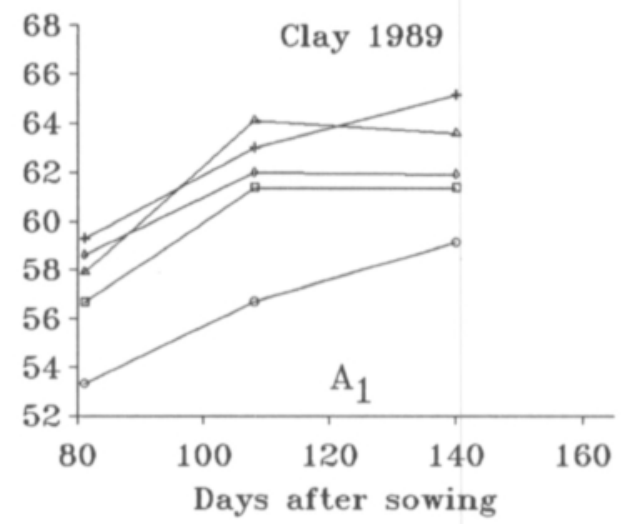

Juice content, \%

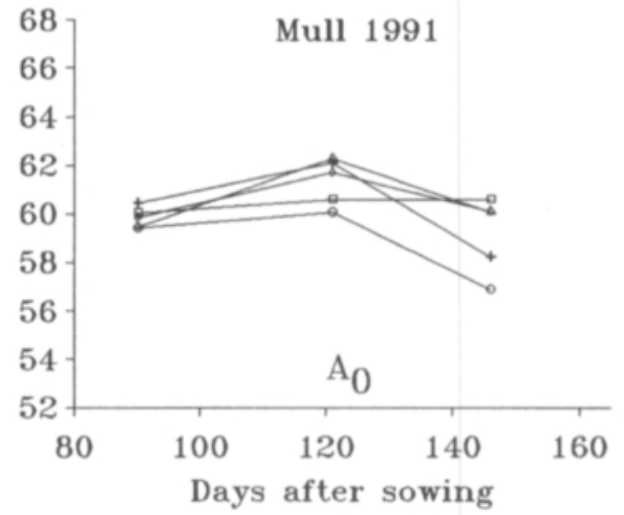

Fig. 32. Tap root juice content as affected by mechanical treatments $\left(B_{1}-B_{5}\right)$ of mull and fine sand and clay under nonirrigated $\left(A_{0}\right)$ and irrigated $\left(A_{1}\right)$ conditions at three sampling times in 1989-1991. $B_{1}=$ soil loosening by ridge preparation, $\mathrm{B}_{2}=$ soil loosening by rotary harrowing, $\mathrm{B}_{3}=$ untreated, $\mathrm{B}_{4}=$ one pass of the tractor wheel, $\mathrm{B}_{5}=$ three passes of the tractor wheel.

HSD eas $_{\text {for significant differences: }}$

Clay: $3.2 \%$ (at the same A level $4.5 \%$ ) 81 days after sowing (DAS), $2.0 \%$ (2.9\%) 108 DAS, 3.7\% (5.2\%) 140 DAS

Mull: 3.9\% 146 DAS in 1991 
Pietola, L.: Effect of soil compactness on the growth and quality of carrot

Dry matter of juice, \%

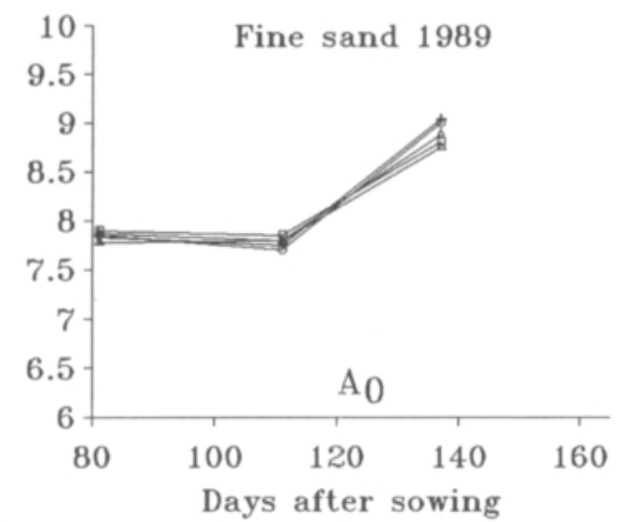

Dry matter of juice, \%

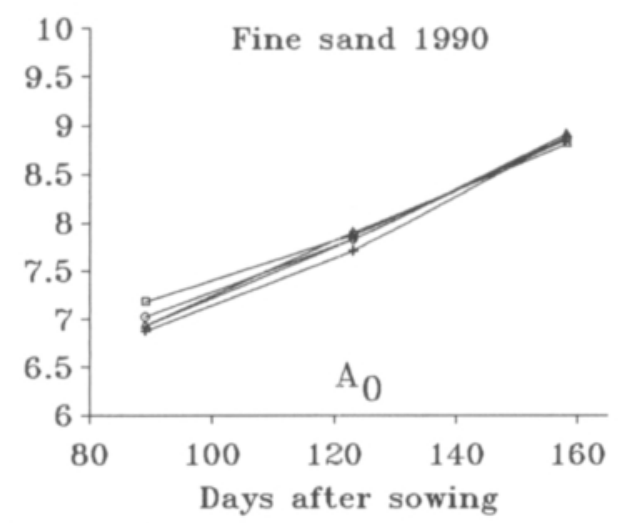

Dry matter of juice, \%

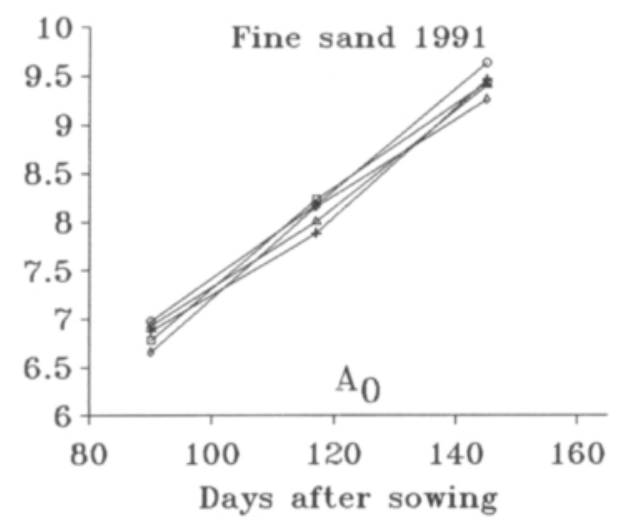

Dry matter of juice, \%

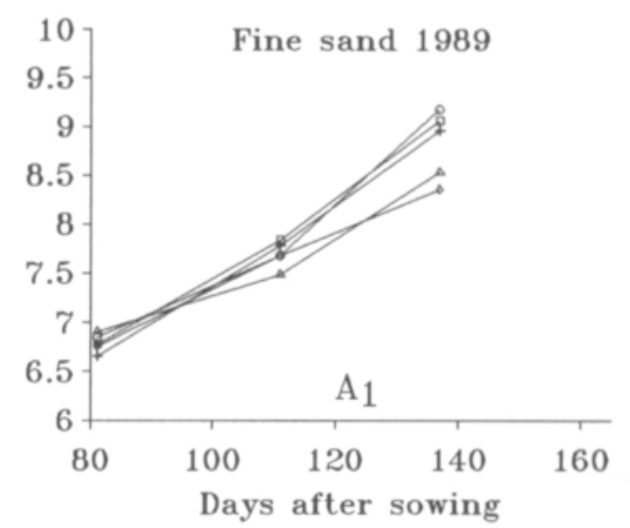

Dry matter of juice, \%

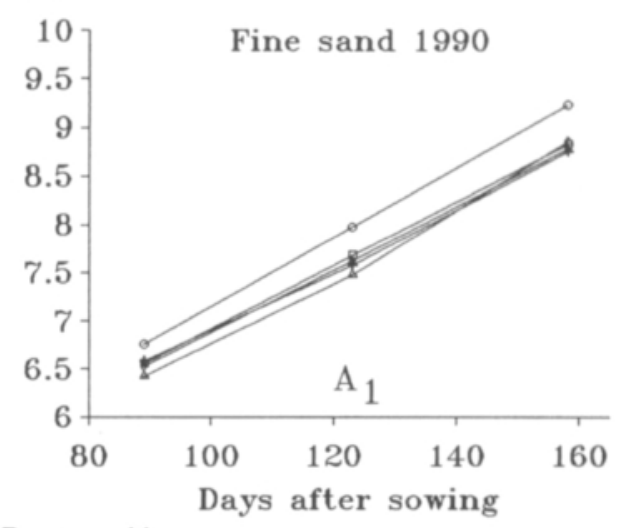

Dry matter of juice, \%

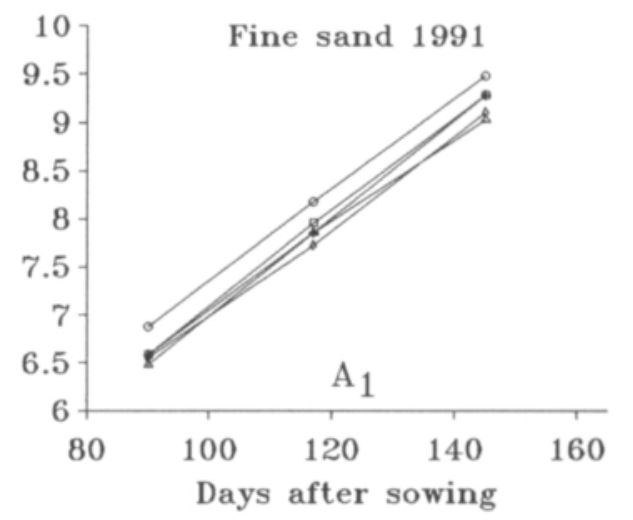

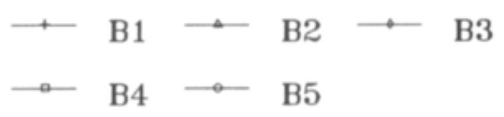


Vol. 4: 139-237.

Dry matter of juice, \%

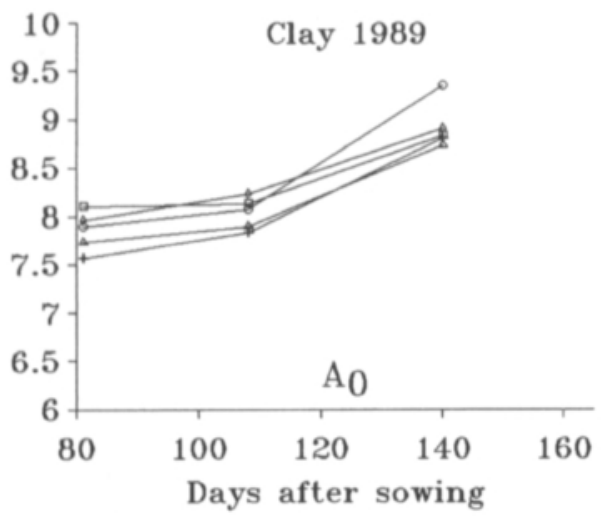

Dry matter

of juice, \%

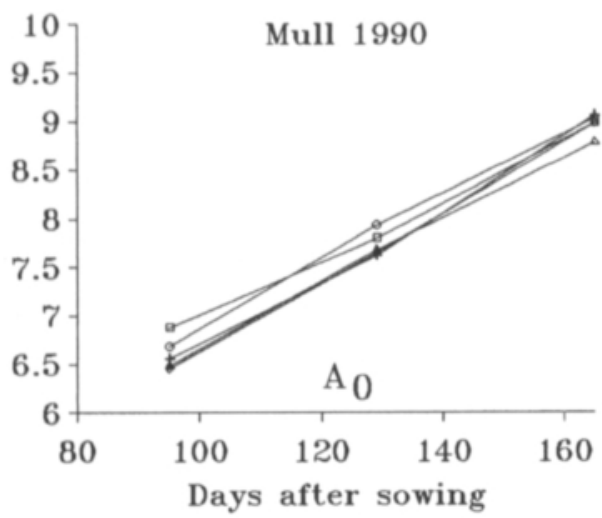

Dry matter of juice, \%

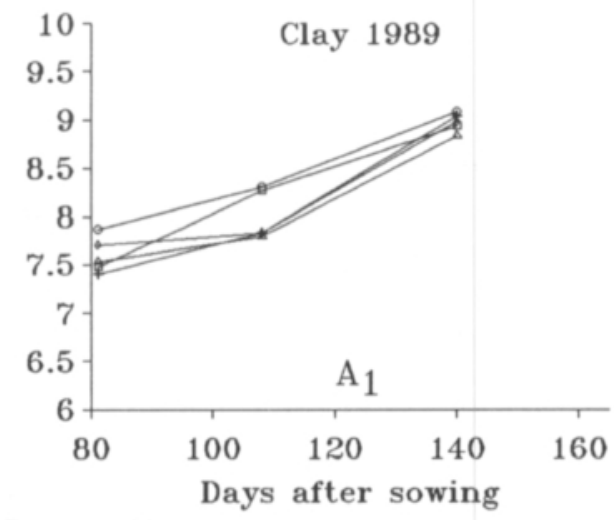

Dry matter of juice, \%

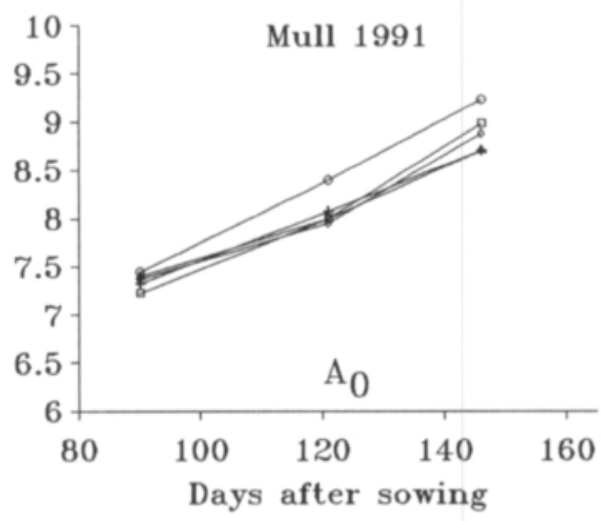

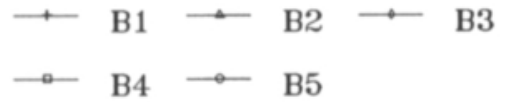

Fig. 33. Dry matter content of tap root juice (juice density) as affected by mechanical treatments $\left(\mathrm{B}_{1}-\mathrm{B}_{5}\right)$ of mull, fine sand and clay under non-irrigated $\left(A_{0}\right)$ and irrigated $\left(A_{1}\right)$ conditions at three sampling times in 1989-1991. $B_{1}=$ soil loosening by ridge preparation, $\mathrm{B}_{2}=$ soil loosening by rotary harrowing, $\mathrm{B}_{3}=$ untreated, $\mathrm{B}_{4}=$ one pass of the tractor wheel, $\mathrm{B}_{5}=$ three passes of the tractor wheel.

HSD $_{\text {ags }}$ for significant differences:

Fine sand: $0.4 \%$ (at the same A level $0.5 \%$ ) 145 days after sowing (DAS) in 1991

Clay: $0.3 \%(0.4 \%) 108$ DAS

Mull: 0.4\% 95 DAS in 1990; 0.5 \% 121 DAS in 1991 


\section{AGRICULTURAL SCIENCE IN FINLAND}

Pietola, L.: Effect of soil compactness on the growth and quality of carrot

fect of sandy soil compaction was found also in 1989 , but only at $\mathrm{P}<0.10$.

At the first sampling in clay soil, the juice dry matter content decreased only by 0.3 percentage units by water applications (Fig. 33). Further, soil compaction had only a small positive effect on juice dry matter content at the second sampling. At this time, there was a significant interaction between treatments because juice dry matter content decreased by water applications in $\mathrm{B}_{3}$ treatment ( 0.5 percentage units), but a slight opposite effect was found in compacted soil. In mull field, juice dry matter content showed some tendency to increase by soil compaction (Fig. 33), but statistically significantly only twice in this experiment, i. e. at the first sampling in 1990 and at the second sampling in 1991.

The juice dry matter content correlated positively with soil moisture recorded on plant sampling days (gypsum block at $15-\mathrm{cm}$ depth, representing the approximate soil moisture status of the past ten days) in clay soil $\left(\mathrm{r}=0.42^{* *}\right)$ and in fine sand in 1990 only slightly $\left(r=0.28^{* *}\right)$. Negative correlations were recorded in $1991\left(\mathrm{r}=-0.83^{* * *}\right.$ for fine sand, $r=-0.46^{* *}$ for mull) when the rainy early summer was followed by a dry late season.

\section{Sugar content}

In fine sand, irrigation had some small effect on sugar concentration as glucose concentration decreased by water applications in $\mathrm{B}_{3}$ treatment at harvest in 1990 (Fig. 34). The effect was inverse both in loosened and compacted soils. This study did not show any significant effect of soil compactness on total root sugar concentration in any soil type. When statistical analyses were carried out for each sugar concentration separately, some statistically significant, but still a very negligible effect, was found in sandy soil. In 1989, as compared with $\mathrm{B}_{2}$ treatment, the sucrose concentration increased by $\mathrm{B}_{5}$ treatment. The difference disappeared in total sugar concentrations because the glucose and fructose concentrations were the highest in the roots of $\mathrm{B}_{2}$ treatment.

\section{Carotene content}

Irrigation affected carotene, but in a very different way in each experimental year (Fig. 35). In 1989 , the concentration of beta carotene in clay soil increased on average by $1 \mathrm{mg}$ by water applications. In the same year, this positive effect of irrigation was $1.5 \mathrm{mg}(\mathrm{P}<0.06)$ in fine sand. In 1990 , on the contrary, the beta carotene concentration decreased by $0.75 \mathrm{mg}$ per $100 \mathrm{~g}$ fresh carrot by irrigation of sandy soil. The role of irrigation was similar in alfa carotene, but the positive effect of water applications in 1989 remained around $0.5 \mathrm{mg}(\mathrm{P}<0.05$ in fine sand, $\mathrm{P}<0.10$ in clay), and the negative effect of 1990 was only $0.3 \mathrm{mg}$. In 1991, no statistically significant effect was found.

In fine sand and clay, neither alfa or beta carotenes differed statistically significantly between mechanical treatments (Fig. 35). In mull, compaction increased the concentration of beta carotene significantly $(1.1 \mathrm{mg}$ per $100 \mathrm{~g}$ fresh carrot) and alfa carotene at $\mathrm{P}<0.10$ as compared with $\mathrm{B}_{2}$ treatment. This was demonstrated in 1990 when carotene contents remained very low after a cool September.

\section{Internal quality vs. roots size}

Some factors of internal quality were dependent on tap root size at harvest, but not in every experimental year and field, as suggested by the coefficients of correlation for dry matter, crude fibre, juice, juice dry matter, sugar and carotene contents. For dry matter, crude fibre and total sugars, a negative correlation was found only in clay soil $(r=-0.60 * * *,-0.37 *$, and $-0.39 *$, respectively). In mull soil in 1991, the correlation between root size and crude fibre $(r=-0.39)$ was significant at $\mathrm{P}<0.10$. For juice dry matter content, the negative correlation with tap root fresh weight was significant in fine sand in $1991(\mathrm{r}=$ $\left.-0.31^{*}\right)$, in addition to clay soil $\left(r=-0.39^{*}\right)$. For juice content, a positive correlation was observed both in clay $\left(\mathrm{r}=0.63^{* * *}\right)$ and fine sand in 1990 $\left(\mathrm{r}=0.38^{*}\right)$, and at $\mathrm{P}<0.10$ in mull soil in 1991 $(r=0.40)$. Carotene content was dependent on root size only in mull in $1990\left(\mathrm{r}=-0.46^{*}\right)$. 
Vol. 4: 139-237.

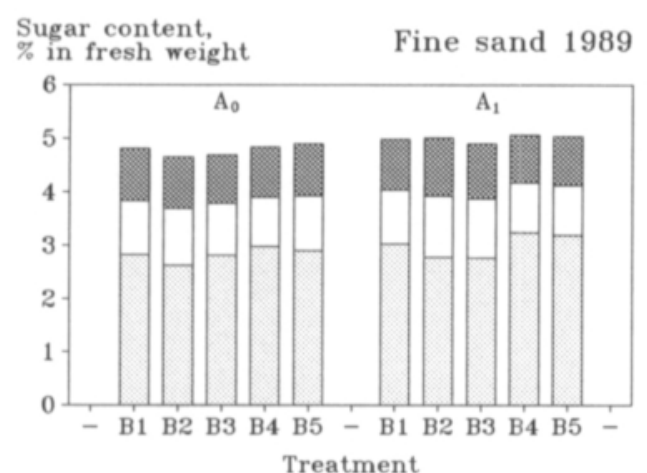

Sugar content, $\%$ in fresh weight

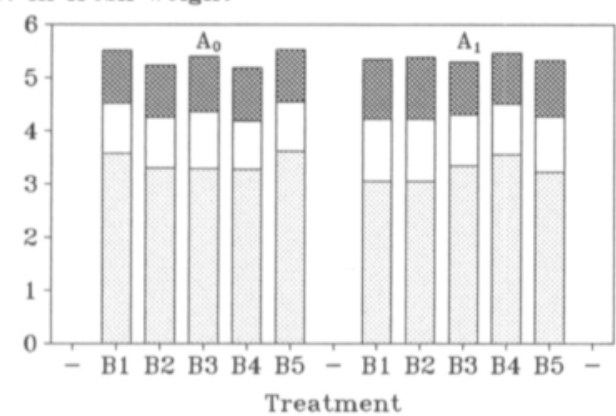

Sugar content, $\%$ in fresh weight

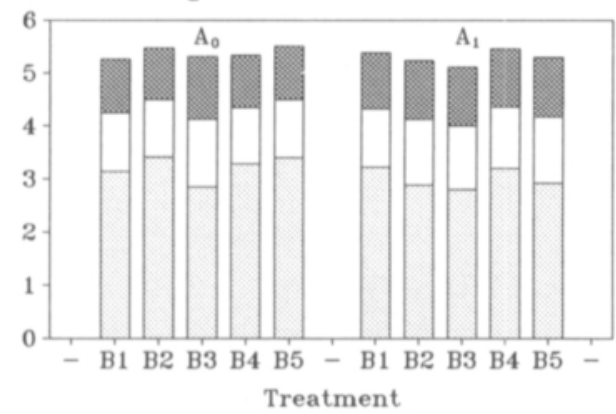

Sugar content,

$\%$ in fresh weight Clay 1989

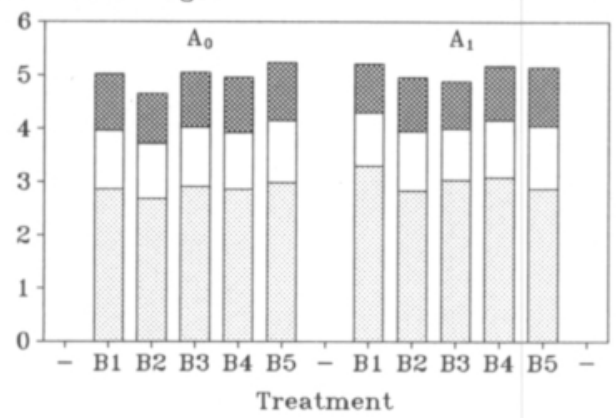

Sugar content,

$\%$ in fresh weight

Mull 1990

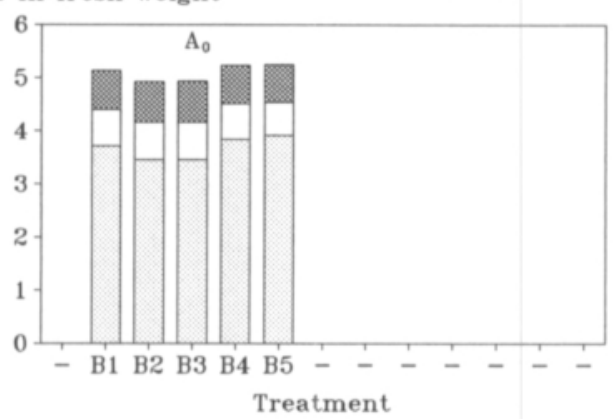

Sugar content,

$\%$ in fresh weight

Mull 1991

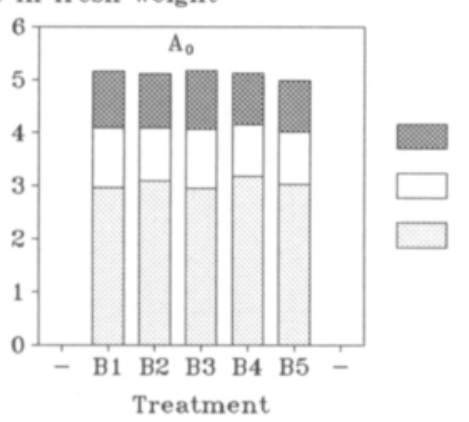

Fructose

Glucose

Sucrose

Fig. 34. Tap root sugar content as affected by mechanical treatments $\left(\mathrm{B}_{1}-\mathrm{B}_{5}\right)$ of mull, fine sand and clay under non-irrigated $\left(A_{0}\right)$ and irrigated $\left(A_{1}\right)$ conditions at third sampling in 1989-1991. $B_{1}=$ soil loosening by ridge preparation, $B_{2}=$ soil loosening by rotary harrowing, $\mathrm{B}_{3}=$ untreated, $\mathrm{B}_{4}=$ one pass of the tractor wheel, $\mathrm{B}_{5}=$ three passes of the tractor wheel.

HSD $_{005}$ for significant differences:

Fine sand: for sucrose $0.4 \%$ (at the same A level $0.6 \%$ ), for glucose $0.1 \%(0.2 \%)$ in 1989 
Pietola, L.: Effect of soil compactness on the growth and quality of carrot

Carotene content, $\mathrm{mg} / 100 \mathrm{~g}$ fresh weight

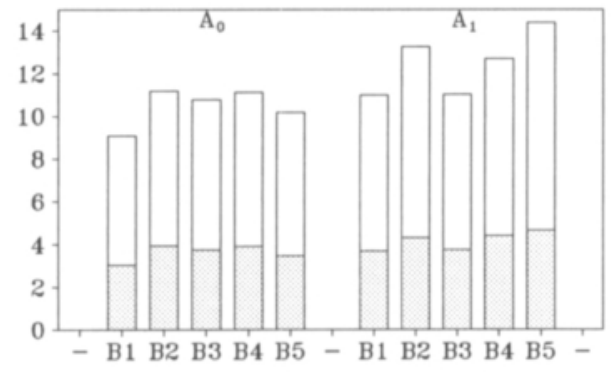

Treatment

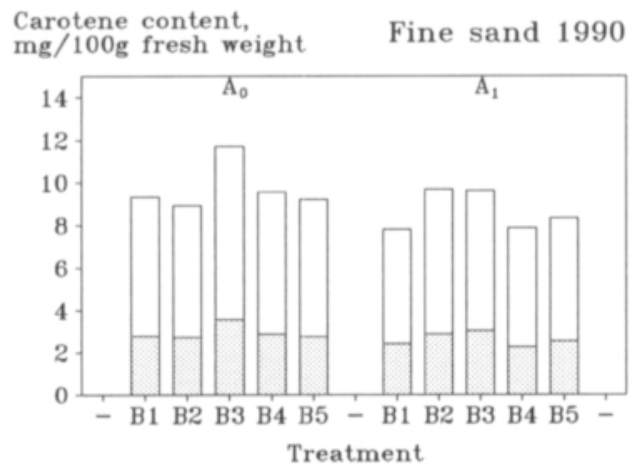

Carotene content, $\mathrm{mg} / 100 \mathrm{~g}$ fresh weight

Fine sand 1991

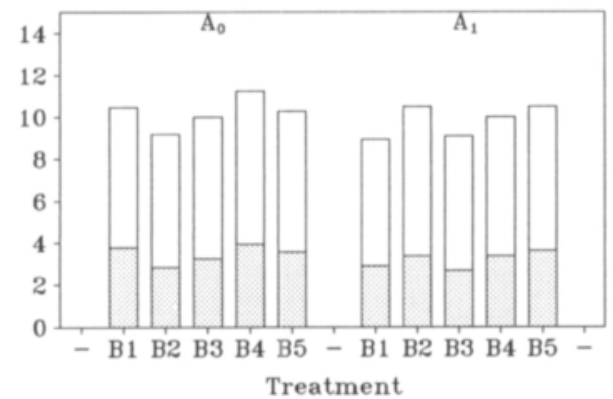

Carotene content, $\mathrm{mg} / 100 \mathrm{~g}$ fresh weight

Clay 1989

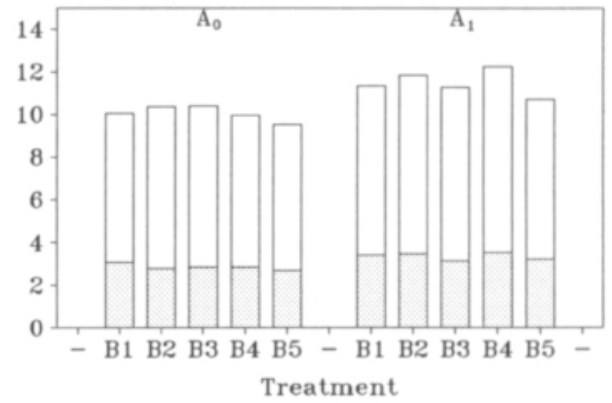

Carotene content, $\mathrm{mg} / 100 \mathrm{~g}$ fresh weight

Mull 1990

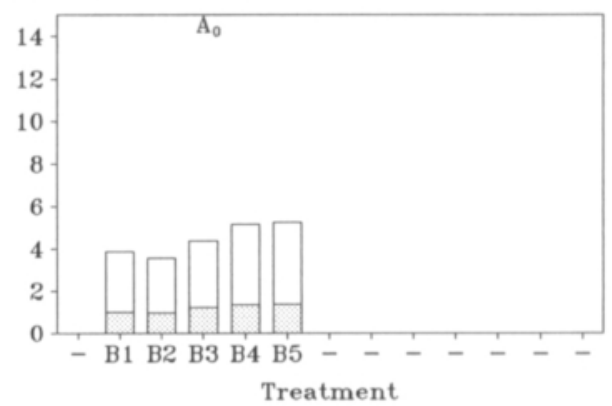

Carotene content, $\mathrm{mg} / 100 \mathrm{~g}$ fresh weight

Mull 1991

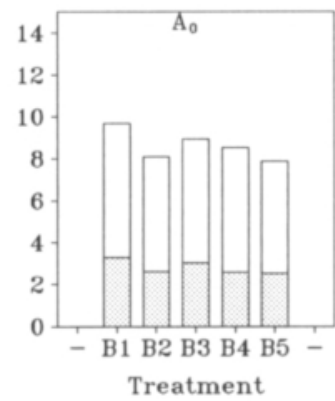

$\beta$-carotene

$\alpha$-carotene

Fig. 35. Tap root carotene contents as affected by mechanical treatments $\left(B_{1}-B_{5}\right)$ of mull, fine sand and clay under nonirrigated $\left(A_{0}\right)$ and irrigated $\left(A_{1}\right)$ conditions at third sampling (harvest) in 1989-1991. $B_{1}=$ soil loosening by ridge preparation, $\mathrm{B}_{2}=$ soil loosening by rotary harrowing, $\mathrm{B}_{3}=$ untreated, $\mathrm{B}_{4}=$ one pass of the tractor wheel, $\mathrm{B}_{5}=$ three passes of the tractor wheel.

$\mathrm{HSD}_{0.05}$ for significant differences:

Mull: for beta carotene $1.1 \%$ in 1990 
Vol. 4: 139-237.

\subsection{Response of whole-root system and shoot growth to differently treated soil profiles in PVC cylinders}

\subsection{Distribution of weights}

\section{Tap root and shoot weight}

According to the preliminary study of clay soil PVC profiles in 1989, soil compaction decreased tap root fresh weight $\left(B_{2}=155 \mathrm{~g}, B_{5}=95 \mathrm{~g}\right)$, while shoot weight remained unaffected. The effects of irrigation and mechanical treatments $\left(B_{2}, B_{5}\right)$ on total tap root biomass and shoot growth in PVC cylinders in 1990-1991 are summarized in Table 15. Irrigation of fine sand increased the tap root weights and shoot dry weights only in 1991. The final shoot weigth was not affected by soil mechanical treatments. Soil compaction decreased the fresh and dry weights of tap roots in fine sand cylinders, but in mull only on fresh weight basis in 1991.

The distribution of tap root dry weights in each $5-\mathrm{cm}$ soil layer was not affected by irrigation (Fig. 36). In fine sand in 1990 at depths of $5-10 \mathrm{~cm}$ and $10-15 \mathrm{~cm}$, soil compaction decreased tap root biomass significantly. After the rainy early summer in 1991, compaction decreased tap root biomass less than in 1990, but still significantly at depths of $10-15 \mathrm{~cm}$ and $15-$ $20 \mathrm{~cm}$ (at $5-10 \mathrm{~cm} \mathrm{P<0.10).} \mathrm{Inversely,} \mathrm{com-}$ paction increased the biomass accumulation in the top soil layer. Statistically significant interactions between treatments were determined at $0-5 \mathrm{~cm}$, where irrigation increased dry weight only in compacted soil, and at $15-20 \mathrm{~cm}$, where irrigation increased dry weight in loose soil but decreased it in compacted soil. In mull soil, the tendency of biomass accumulation of tap roots at surface soil by soil compaction was significant at $\mathrm{P}<0.10$ (1991). The tap root dry weight was significantly diminished by soil compaction at the depth of $10-15 \mathrm{~cm}$ in 1991 and at $15-20$ $\mathrm{cm}$ in both years. The clear difference of $1.7 \mathrm{~g}$ at the depth of $5-10 \mathrm{~cm}$ in mull soil in 1991 was significant at $\mathrm{P}<0.06$.

\section{Fibrous root weight}

According to the preliminary studies of PVC profiles in 1989, soil compaction had no significant effect on fibrous root dry weight accumulation in clay soil. In relation to tap root dry weight, the fibrous root dry weight tended to increase by soil compaction (Appendix 5). Some roots were observed below the soil depth of $60 \mathrm{~cm}$.

Table 16 shows the total dry weights per plant for 1990-1991 summarized at the depth range of 0-50 cm. In fine sand, no effects of treatments were observed in 1990 for a small root system, at sampling 10 days after harvest. In 1991, when sampling was performed at harvest, the dry weight for a larger root system increased both by soil irrigation and compaction. In mull, compaction increased the total dry weight of the fibrous root system in 1990 .

In fine sand in 1990, the dry mass distribution of fibrous root weights per plant was increased by irrigation at the depth of 25$30 \mathrm{~cm}$ (Fig. 37). As compared with the profile for the loosened soil, a larger amount of fibrous roots was found in compacted soil at the depth of $10-15 \mathrm{~cm}$. The weight of fibrous roots was $25 \%$ higher in compacted soil at the depth of $15-25 \mathrm{~cm}$ than in loose fine sand. In comparison with irrigated cylinders, soil compactness did not affect fibrous root weights significantly.

In 1991, a very remarkable positive effect of irrigation was observed at $15-20 \mathrm{~cm}$, with an increase from 21 to $29 \mu \mathrm{g} \mathrm{cm}^{-3}$ soil, and at $20-25 \mathrm{~cm}$ from 19 to $32 \mu \mathrm{g} \mathrm{cm}^{-3}$. That year, the larger fibrous root system was affected more by soil compaction than in 1990. Fibrous root weight increased by soil compaction in all $5-\mathrm{cm}$ layers at the depth of $5-25 \mathrm{~cm}$. In subsoil, a small positive effect of soil compaction was observed at the depth of $45-50 \mathrm{~cm}$. In 1990, mull compaction increased fibrous 
Pietola, L.: Effect of soil compactness on the growth and quality of carrot

Table 15. Total fresh weight (TFW) and dry weight (TDW) of tap roots and shoots per plant $(n=6)$ in PVC cylinders of rotary harrowed $\left(B_{2}\right)$ and three times compacted $\left(B_{5}\right)$ soils. $A_{0}=$ non-irrigated, $A_{1}=$ irrigated.

\begin{tabular}{|c|c|c|c|c|c|c|c|}
\hline \multirow[t]{2}{*}{ Soil } & \multirow[t]{2}{*}{ Year } & \multirow[t]{2}{*}{ Treatment } & \multicolumn{2}{|c|}{ Tap root, g plant ${ }^{-1}$} & \multicolumn{2}{|c|}{ Shoot, g plant ${ }^{-1}$} & \multirow{2}{*}{$\frac{\text { Shoot:root }}{\text { TDW:TDW }}$} \\
\hline & & & TFW & TDW & TFW & TDW & \\
\hline \multirow{11}{*}{$\begin{array}{l}\text { Fine } \\
\text { sand }\end{array}$} & \multirow[t]{11}{*}{1990} & $\mathrm{~A}_{0} \mathrm{~B}_{2}$ & 170 & 17 & 20 & 4.3 & 0.25 \\
\hline & & $\mathrm{A}_{0} \mathrm{~B}_{5}$ & 100 & 11 & 17 & 3.8 & 0.35 \\
\hline & & $\mathrm{A}_{1} \mathrm{~B}_{2}$ & 140 & 15 & 22 & 4.6 & 0.29 \\
\hline & & $\mathrm{A}_{1} \mathrm{~B}_{5}$ & 110 & 12 & 18 & 3.6 & 0.30 \\
\hline & & $\mathrm{HSD}_{0.05}(\mathrm{~B})$ & 40 & 4 & n.s. ${ }^{1)}$ & n.s. & n.s. \\
\hline & & mean $\left(A_{0}\right)$ & 140 & 14 & 18 & 4.0 & 0.30 \\
\hline & & mean $\left(A_{1}\right)$ & 130 & 14 & 20 & 4.1 & 0.30 \\
\hline & & $\mathrm{HSD}_{0.05}$ & n.s. & n.s. & n.s. & n.s. & n.s. \\
\hline & & mean $\left(B_{2}\right)$ & 150 & 16 & 21 & 4.4 & 0.27 \\
\hline & & mean $\left(\mathrm{B}_{5}\right)$ & 110 & 12 & 18 & 3.7 & 0.33 \\
\hline & & $\mathrm{HSD}_{0.05}$ & 30 & 3 & n.s. & n.s. & n.s. \\
\hline \multirow{11}{*}{$\begin{array}{l}\text { Fine } \\
\text { sand }\end{array}$} & \multirow[t]{11}{*}{1991} & $\mathrm{~A}_{0} \mathrm{~B}_{2}$ & 110 & 10 & 20 & 3.5 & 0.33 \\
\hline & & $\mathrm{A}_{0} \mathrm{~B}_{5}$ & 90 & 10 & 22 & 3.7 & 0.39 \\
\hline & & $\mathrm{A}_{1} \mathrm{~B}_{2}$ & 120 & 12 & 26 & 4.3 & 0.36 \\
\hline & & $\mathrm{A}_{1} \mathrm{~B}_{5}$ & 100 & 11 & 26 & 4.2 & 0.40 \\
\hline & & $\mathrm{HSD}_{0.05}(\mathrm{~B})$ & 20 & 2 & 6 & n.s. & n.s. \\
\hline & & mean $\left(A_{0}\right)$ & 100 & 10 & 21 & 3.6 & 0.38 \\
\hline & & mean $\left(A_{1}\right)$ & 110 & 11 & 26 & 4.3 & 0.36 \\
\hline & & $\mathrm{HSD}_{005}$ & 10 & 1 & n.s. & 0.7 & n.s. \\
\hline & & mean $\left(B_{2}\right)$ & 120 & 11 & 23 & 3.9 & 0.35 \\
\hline & & mean $\left(B_{5}\right)$ & 90 & 10 & 24 & 4.0 & 0.40 \\
\hline & & $\mathrm{HSD}_{005}$ & 10 & 1 & n.s. & n.s. & n.s. \\
\hline \multirow[t]{3}{*}{ Mull } & \multirow[t]{3}{*}{1990} & $\mathrm{~A}_{0} \mathrm{~B}_{2}$ & 150 & 15 & 20 & 4.0 & 0.27 \\
\hline & & $\mathrm{A}_{0} \mathrm{~B}_{5}$ & 140 & 14 & 23 & 4.6 & 0.33 \\
\hline & & $\mathrm{HSD}_{005}$ & n.s. & n.s. & n.s. & n.s. & n.s. \\
\hline \multirow[t]{3}{*}{ Mull } & \multirow[t]{3}{*}{1991} & $\mathrm{~A}_{0} \mathrm{~B}_{2}$ & 110 & 12 & 36 & 5.4 & 0.48 \\
\hline & & $\mathrm{A}_{0} \mathrm{~B}_{5}$ & 90 & 11 & 38 & 5.7 & 0.55 \\
\hline & & $\mathrm{HSD}_{005}$ & 20 & n.s. & n.s. & n.s. & n.s. \\
\hline
\end{tabular}

1) n.s. = not significant

root dry weight at $10-20 \mathrm{~cm}$. In 1991 , the increase was significant at $5-15 \mathrm{~cm}$ (at $15-20 \mathrm{~cm}$ at $\mathrm{P}<0.10)$.

\section{Fibrous root weight to tap root weight ratio}

For the whole root system, at the depth of 0 $50 \mathrm{~cm}$, the fibrous root dry weight related to tap root biomass was not affected by irrigation of fine sand, but was higher in compacted fine sand than in loose soil in 1990-1991 (Table 16). Mull soil compaction did not affect this ratio. In fine sand in 1990, fibrous root dry weight distribution related to tap root biomass, $\mathrm{mg} \mathrm{g}^{-1}$ tap root dry weight, increased by irrigation at the depth of $25-30 \mathrm{~cm}$, from 1.4 to $2.3 \mathrm{mg} \mathrm{g}^{-1}$ (Fig. 38). 
Vol. 4: 139-237.

Soil depth, cm

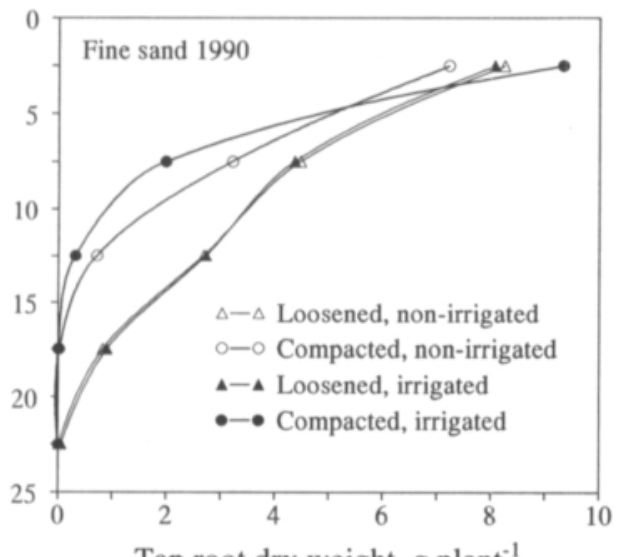

Tap root dry weight, $\mathrm{g}$ plant ${ }^{-1}$

Soil depth, cm

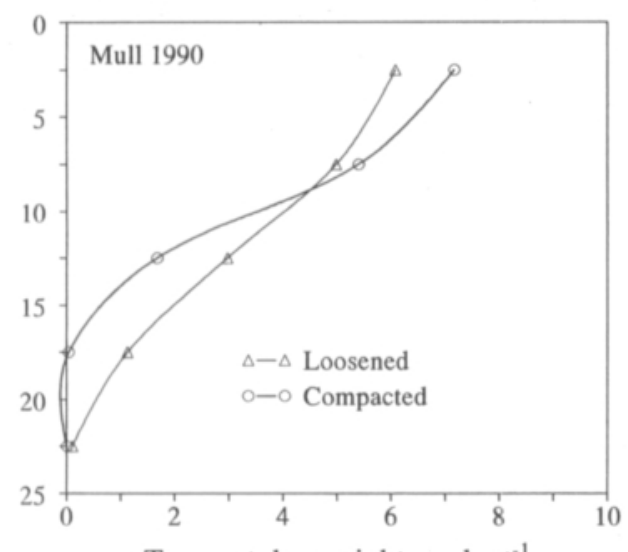

Tap root dry weight, $g$ plant ${ }^{-1}$
Soil depth, cm

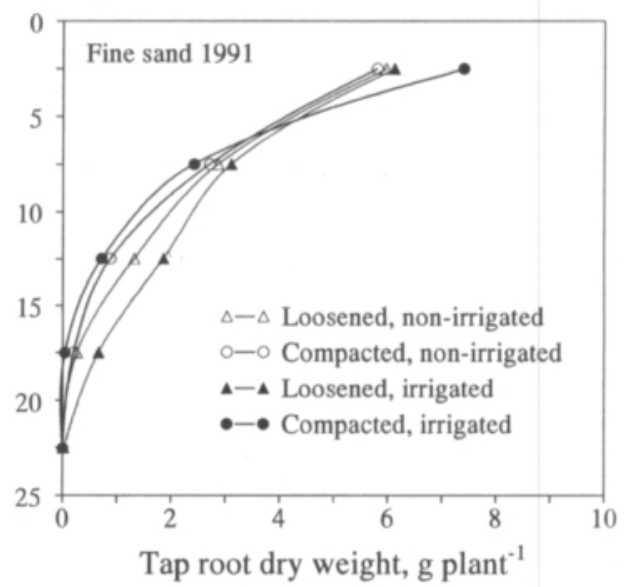

Soil depth, cm

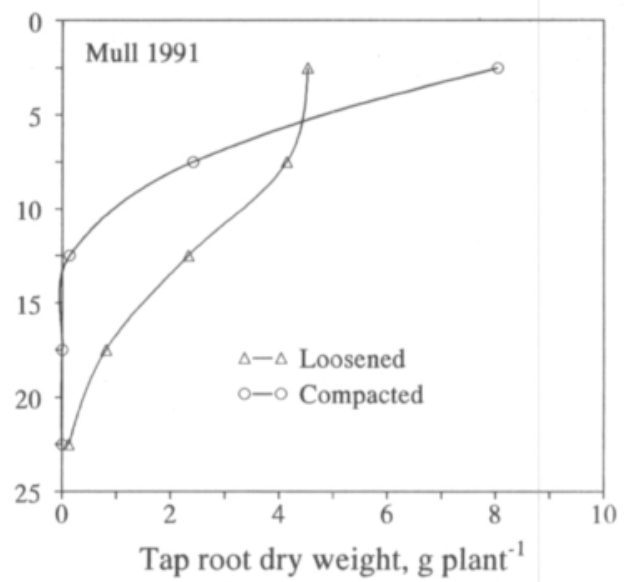

Fig. 36. Tap root dry weight per plant in PVC cylinders in fine sand and mull in 1990-1991 as affected by rotary harrowing (Loosened) and three passes of the tractor wheel (Compacted) under non-irrigated $\left(A_{0}\right)$ and irrigated conditions $\left(A_{1}\right)$.

$\mathrm{HSD}_{\mathrm{as}}$ for significant differences:

Fine sand in 1990: $0.3 \mathrm{~g}$ (at the same A level $0.5 \mathrm{~g}$ ) at $5-10 \mathrm{~cm}, 0.1 \mathrm{~g}(0.2 \mathrm{~g})$ at $10-15 \mathrm{~cm}$

Fine sand in $1991: 0.6 \mathrm{~g}(1.5 \mathrm{~g})$ at $0-5 \mathrm{~cm}, 0.4 \mathrm{~g}(0.9 \mathrm{~g})$ at $10-15 \mathrm{~cm}, 0.1 \mathrm{~g}(0.3 \mathrm{~g})$ at $15-20 \mathrm{~cm}$

Mull in 1990: $0.7 \mathrm{~g}$ at $15-20 \mathrm{~cm}$

Mull in 1991: $1.4 \mathrm{~g}$ at $10-15 \mathrm{~cm}, 0.9 \mathrm{~g}$ at $15-20 \mathrm{~cm} 0.9 \mathrm{~g}$ 
Pietola, L.: Effect of soil compactness on the growth and quality of carrot

Table 16. Total dry weight (TDW), length (TL) and surface area (TSA) of fibrous roots per plant and per tap root dry weight in PVC cylinders of rotary harrowed $\left(\mathrm{B}_{2}\right)$ and three times compacted $\left(\mathrm{B}_{5}\right)$ soils at the depth of $0-50 \mathrm{~cm} . \mathrm{A}_{0}=$ non-irrigated, $\mathrm{A}_{1}=$ irrigated.

\begin{tabular}{|c|c|c|c|c|c|c|c|c|}
\hline \multirow[t]{2}{*}{ Soil } & \multirow[t]{2}{*}{ Year } & \multirow[t]{2}{*}{ Treatment } & $\begin{array}{c}\text { TDW } \\
(\mathrm{g})\end{array}$ & $\begin{array}{l}\mathrm{TL} \\
(\mathrm{m})\end{array}$ & $\begin{array}{l}\text { TSA } \\
\left(\mathrm{cm}^{2}\right)\end{array}$ & $\begin{array}{l}\text { TDW } \\
(\mathrm{mg})\end{array}$ & $\begin{array}{l}\mathrm{TL} \\
(\mathrm{m})\end{array}$ & $\begin{array}{l}\text { TSA } \\
\left(\mathrm{cm}^{2}\right)\end{array}$ \\
\hline & & & \multicolumn{3}{|c|}{ Plant $(n=6)^{-1}$} & \multicolumn{3}{|c|}{ Tap root dry weight $(\mathrm{g})^{-1}$} \\
\hline \multirow{11}{*}{$\begin{array}{l}\text { Fine } \\
\text { sand }\end{array}$} & \multirow[t]{11}{*}{1990} & $\mathrm{~A}_{0} \mathrm{~B}_{2}$ & 0.30 & \multirow[t]{11}{*}{ n.d. ${ }^{1)}$} & \multirow[t]{11}{*}{ n.d. } & 18 & \multirow[t]{11}{*}{ n.d. } & \multirow[t]{11}{*}{ n.d. } \\
\hline & & $\mathrm{A}_{0} \mathrm{~B}_{5}$ & 0.34 & & & 31 & & \\
\hline & & $\mathrm{A}_{1} \mathrm{~B}_{2}$ & 0.34 & & & 23 & & \\
\hline & & $\mathrm{A}_{1} \mathrm{~B}_{5}$ & 0.38 & & & 34 & & \\
\hline & & $\mathrm{HSD}_{0.05}(\mathrm{~B})$ & n.s. ${ }^{2}$ & & & 14 & & \\
\hline & & mean $\left(\mathrm{A}_{0}\right)$ & 0.32 & & & 25 & & \\
\hline & & mean $\left(A_{1}\right)$ & 0.36 & & & 28 & & \\
\hline & & $\mathrm{HSD}_{0.05}$ & n.s. & & & n.s. & & \\
\hline & & mean $\left(B_{2}\right)$ & 0.32 & & & 21 & & \\
\hline & & mean $\left(\mathrm{B}_{5}\right)$ & 0.36 & & & 33 & & \\
\hline & & $\mathrm{HSD}_{0.05}$ & n.s. & & & 10 & & \\
\hline \multirow{11}{*}{$\begin{array}{l}\text { Fine } \\
\text { sand }\end{array}$} & \multirow[t]{11}{*}{1991} & $\mathrm{~A}_{0} \mathrm{~B}_{2}$ & 0.37 & 120 & 660 & 37 & 12 & 66 \\
\hline & & $\mathrm{A}_{0} \mathrm{~B}_{5}$ & 0.59 & 170 & 1010 & 62 & 18 & 104 \\
\hline & & $\mathrm{A}_{1} \mathrm{~B}_{2}$ & 0.50 & 180 & 960 & 43 & 15 & 82 \\
\hline & & $\mathrm{A}_{1} \mathrm{~B}_{5}$ & 0.77 & 200 & 1190 & 73 & 19 & 113 \\
\hline & & $\mathrm{HSD}_{0.05}(\mathrm{~B})$ & 0.24 & 70 & 400 & 23 & 6 & 38 \\
\hline & & mean $\left(A_{0}\right)$ & 0.48 & 150 & 830 & 49 & 15 & 85 \\
\hline & & mean $\left(A_{1}\right)$ & 0.64 & 190 & 1070 & 58 & 17 & 97 \\
\hline & & $\mathrm{HSD}_{0.05}$ & 0.09 & 30 & 140 & n.s. & n.s. & n.s. \\
\hline & & mean $\left(\mathrm{B}_{2}\right)$ & 0.44 & 150 & 810 & 40 & 14 & 72 \\
\hline & & mean $\left(B_{5}\right)$ & 0.68 & 190 & 1100 & 67 & 18 & 110 \\
\hline & & $\mathrm{HSD}_{0.05}$ & 0.17 & n.s. & 280 & 16 & 4 & 25 \\
\hline \multirow[t]{3}{*}{ Mull } & \multirow[t]{3}{*}{1990} & $\mathrm{~A}_{0} \mathrm{~B}_{2}$ & 0.94 & 210 & 1400 & 65 & 15 & 95 \\
\hline & & $\mathrm{A}_{0} \mathrm{~B}_{5}$ & 1.15 & 230 & 1550 & 82 & 17 & 117 \\
\hline & & $\mathrm{HSD}_{0.05}$ & 0.13 & 20 & 120 & n.s. & n.s. & n.s. \\
\hline \multirow[t]{3}{*}{ Mull } & \multirow[t]{3}{*}{1991} & $\mathrm{~A}_{0} \mathrm{~B}_{2}$ & 0.85 & 240 & 1340 & 76 & 21 & 126 \\
\hline & & $\mathrm{A}_{0} \mathrm{~B}_{5}$ & 1.10 & 300 & 1900 & 109 & 30 & 190 \\
\hline & & $\mathrm{HSD}_{0.05}$ & n.s. & n.s. & n.s. & n.s. & n.s. & n.s. \\
\hline
\end{tabular}

${ }^{1)}$ n.d. = not determined

${ }^{2)}$ n.s. = not significant

The ratio was higher in compacted soil than in loosened fine sand at the depth of $5-15 \mathrm{~cm}$. In 1991 , the ratio increased by irrigation at 15-20 from 7.8 to $9.5 \mathrm{mg} \mathrm{g}^{-1}(\mathrm{P}<0.10)$ and at $20-25$ $\mathrm{cm}$ significantly, from 7.1 to $10.3 \mathrm{mg} \mathrm{g}^{-1}$. A positive effect of soil compaction was demonstrat- ed at the depths of 5-25 cm and 40-50 cm. In mull in 1990, the increase of the ratio by soil compaction was not significant. In 1991, mull soil compaction increased the ratio at $5-10 \mathrm{~cm}$, but at the depths of $10-15 \mathrm{~cm}$ and $35-40 \mathrm{~cm}$ only at $\mathrm{P}<0.10$. 
Vol. 4: 139-237.

Soil depth, cm

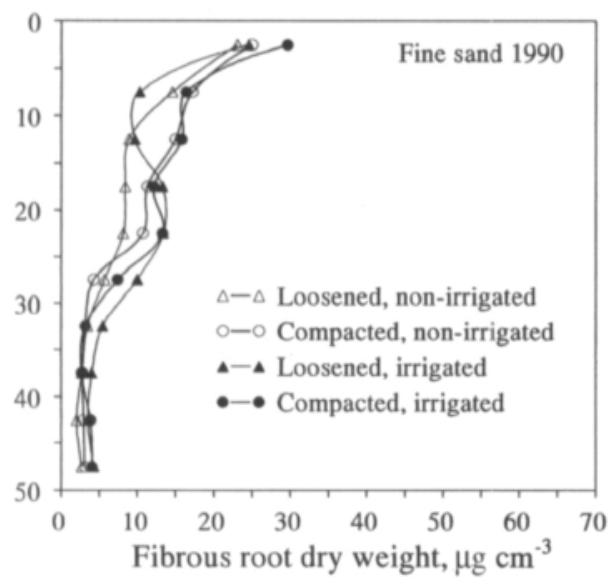

Soil depth, $\mathrm{cm}$

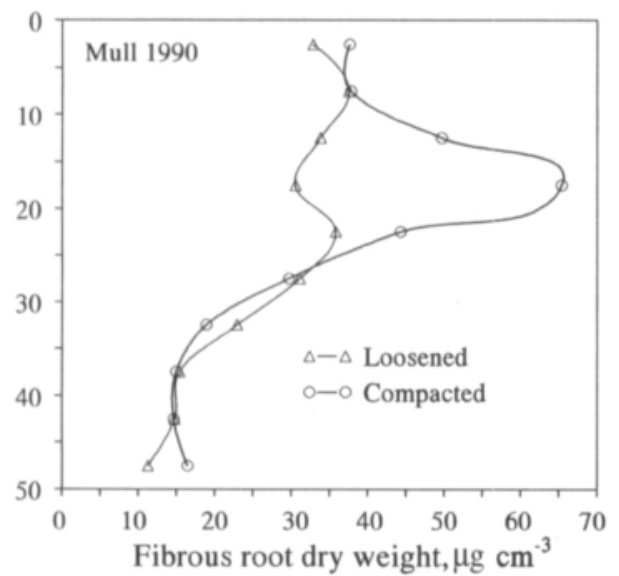

Soil depth, cm

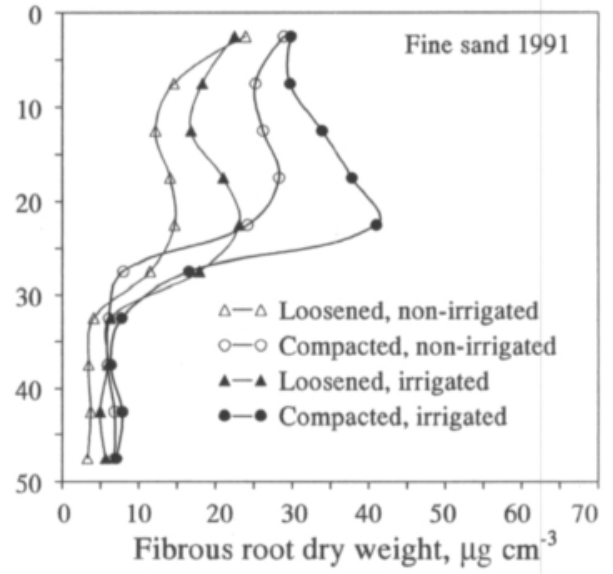

Soil depth, cm

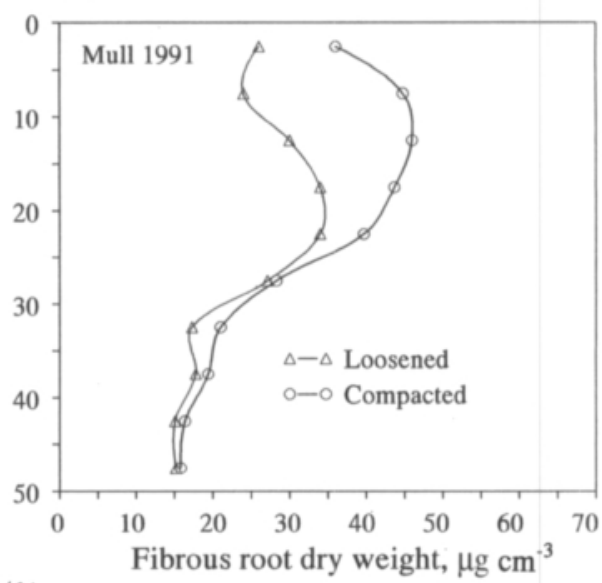

Fig. 37. Fibrous root dry weight per plant in PVC cylinders in fine sand and mull in 1990-1991 as affected by rotary harrowing (Loosened) and three passes of the tractor wheel (Compacted) under non-irrigated $\left(\mathrm{A}_{0}\right)$ and irrigated conditions $\left(A_{1}\right)$. The results are from whole sample material.

HSD $_{00}$ for significant differences:

Fine sand in 1990: $3.4 \mu \mathrm{g} \mathrm{cm}^{-3}$ (at the same A level $4.6 \mu \mathrm{g} \mathrm{cm}^{-3}$ ) at $10-15 \mathrm{~cm}, 0.1 \mu \mathrm{g} \mathrm{cm}^{-3}\left(0.2 \mu \mathrm{g} \mathrm{cm}^{-3}\right)$ at $30-35 \mathrm{~cm}^{-3}$

Fine sand in 1991: $12.8 \mu \mathrm{g} \mathrm{cm}^{-3}\left(18.0 \mu \mathrm{g} \mathrm{cm}^{-3}\right)$ at $10-15 \mathrm{~cm}, 5.5 \mu \mathrm{g} \mathrm{cm}^{-3}\left(7.8 \mu \mathrm{g} \mathrm{cm}^{-3}\right)$ at $\left.15-20 \mathrm{~cm}_{1} 14.2 \mu \mathrm{g} \mathrm{cm}^{-3}(20.1 \mu \mathrm{g} \mathrm{cm})^{-3}\right)$ at $20-25 \mathrm{~cm}^{-0.9} \mu \mathrm{gm}^{-3}$

$\left(1.2 \mu \mathrm{g} \mathrm{cm}^{-3}\right)$ at $45-50 \mathrm{~cm}$

Mull in 1990: $16.0 \mu \mathrm{g} \mathrm{cm}^{-3}$ at $10-15 \mathrm{~cm}, 20.7 \mu \mathrm{g} \mathrm{cm}^{-3}$ at $15-20 \mathrm{~cm}$

Mull in 1991: $18.7 \mu \mathrm{g} \mathrm{cm}^{-3}$ at $5-10 \mathrm{~cm}, 13.9 \mu \mathrm{g} \mathrm{cm}^{-3}$ at $10-15 \mathrm{~cm}$

\subsubsection{Distribution of fibrous root length}

\section{Root length per plant}

The total root length at $0-50 \mathrm{~cm}$ increased by irrigation, and compaction (at $\mathrm{P}<0.10)(\mathrm{Ta}-$ ble 16). In fine sand, irrigation increased root length per soil volume (Fig. 39) at 10-15 cm from 0.57 to $0.80 \mathrm{~cm} \mathrm{~cm}^{-3}$ ( $\left.\mathrm{P}<0.10\right)$, at $15-$ $20 \mathrm{~cm}$ from 0.58 to $0.77 \mathrm{~cm} \mathrm{~cm}^{-3}$, at $20-25 \mathrm{~cm}$ from 0.52 to $0.78 \mathrm{~cm} \mathrm{~cm}^{-3}(\mathrm{P}<0.06)$ and at $25-$ $30 \mathrm{~cm}$ from 0.24 to $0.40 \mathrm{~cm} \mathrm{~cm}^{-3}$ (at $\mathrm{P}<0.10$ ), 
Pietola, L.: Effect of soil compactness on the growth and quality of carrot

Soil depth, cm

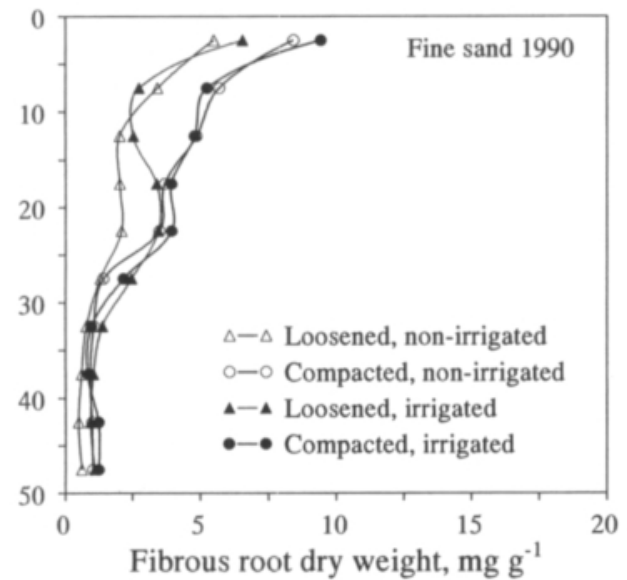

Soil depth, cm

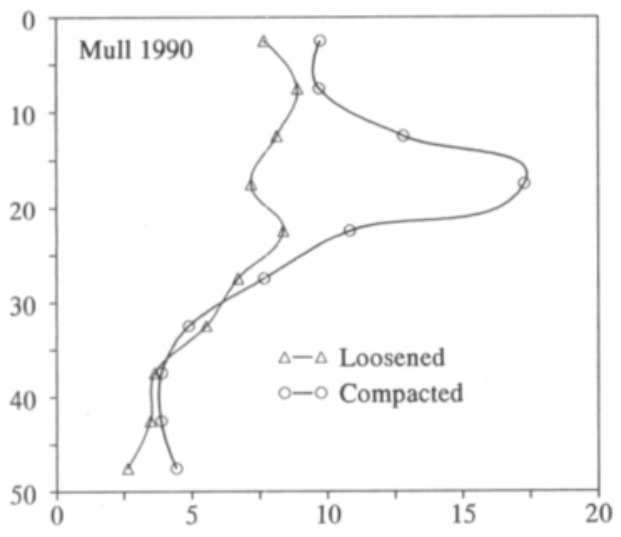

Fibrous root dry weight, $\mathrm{mg} \mathrm{g}^{-1}$
Soil depth, cm

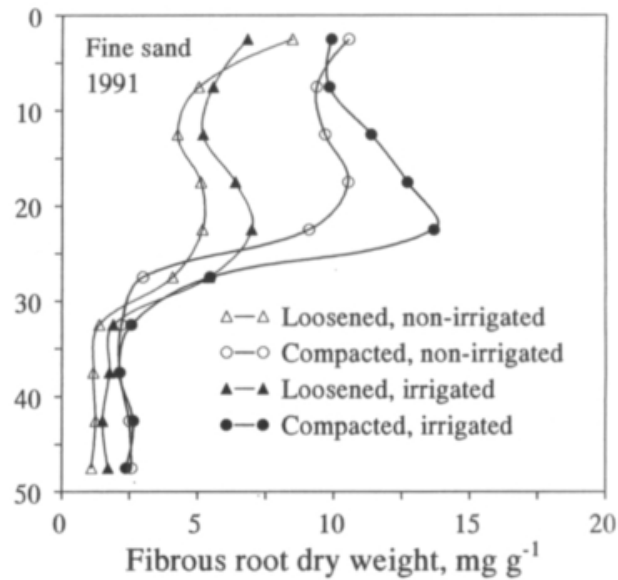

Soil depth, cm

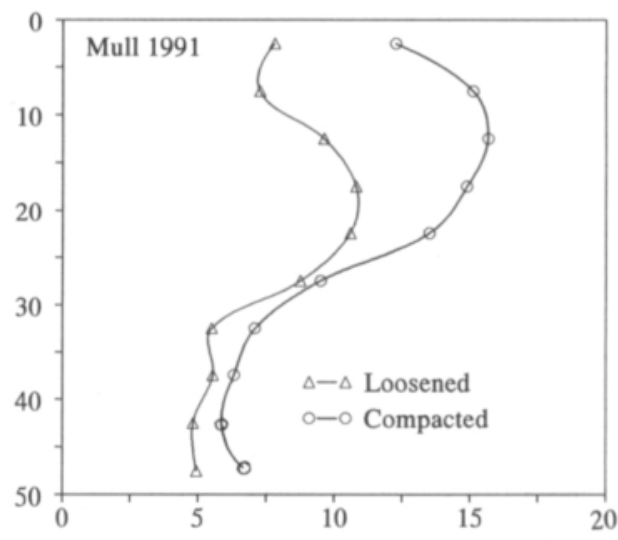

Fibrous root dry weight, $\mathrm{mg} \mathrm{g}^{-1}$

Fig. 38. Fibrous root dry weight in relation to tap root dry weight in PVC cylinders in fine sand and mull in 1990-1991 as affected by rotary harrowing (Loosened) and three passes of the tractor wheel (Compacted) under non-irrigated $\left(\mathrm{A}_{0}\right)$ and irrigated conditions $\left(\mathrm{A}_{1}\right)$. The results are from whole sample material.

$\mathrm{HSD}_{0.05}$ for significant differences:

Fine sand in 1990: $1.6 \mathrm{mg} \mathrm{g}^{-1}$ (at the same A level $\left.2.2 \mathrm{mg} \mathrm{g}^{-1}\right)$ at $5-10 \mathrm{~cm}, 0.5 \mathrm{mg} \mathrm{g}^{-1}\left(0.7 \mathrm{mg} \mathrm{g}^{-1}\right)$ at $10-15 \mathrm{~cm}$

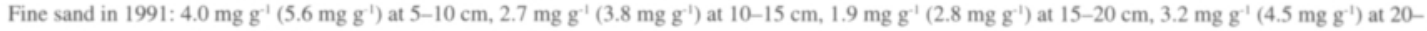
$25 \mathrm{~cm}, 0.9 \mathrm{mg} \mathrm{g}^{-1}\left(1.2 \mathrm{mg} \mathrm{g}^{-1}\right)$ at $40-45 \mathrm{~cm}, 0.5 \mathrm{mg} \mathrm{g}^{-1}\left(0.7 \mathrm{mg} \mathrm{g}^{-1}\right)$ at $45-50 \mathrm{~cm}$

Mull in 1991: $6.6 \mathrm{mg} \mathrm{g}^{-1}$ at $5-10 \mathrm{~cm}$

after analysis of the whole sample material (Procedure 1). At 0-10 cm, according to subsampling (Procedure 2), irrigation did not affect root length density. The correlation between root lengths at $10-50 \mathrm{~cm}$ according to Procedures 1 and 2 was similar $\left(\mathrm{r}=0.98^{* * *}\right)$.

Fibrous root length density was adversely affected by fine sand loosening particularly un- der non-irrigated conditions. A significant positive effect of fine sand compaction on root length density was observed at the depth of 10-25 cm (at $20-25 \mathrm{~cm} \mathrm{P}<0.10$ ). In subsoil, the positive effect of soil compaction remained statistically significant at the depth of $40-45 \mathrm{~cm}$. In mull soil, the tendency of soil compaction to increase root length density particularly at the depth of 
Vol. 4: 139-237.

Soil depth, cm

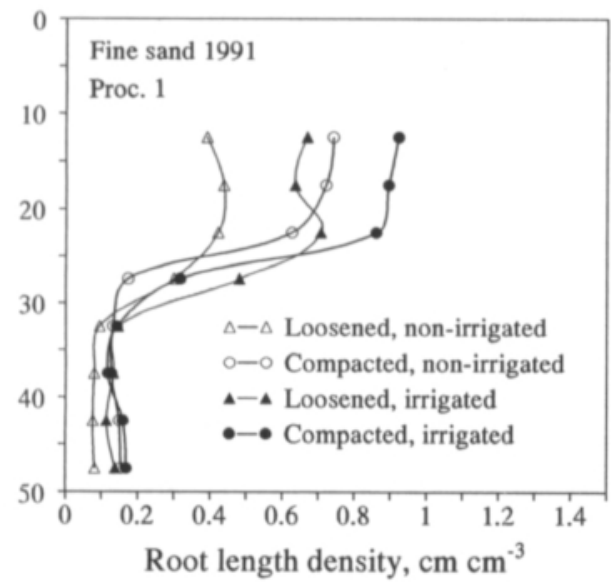

Soil depth, cm

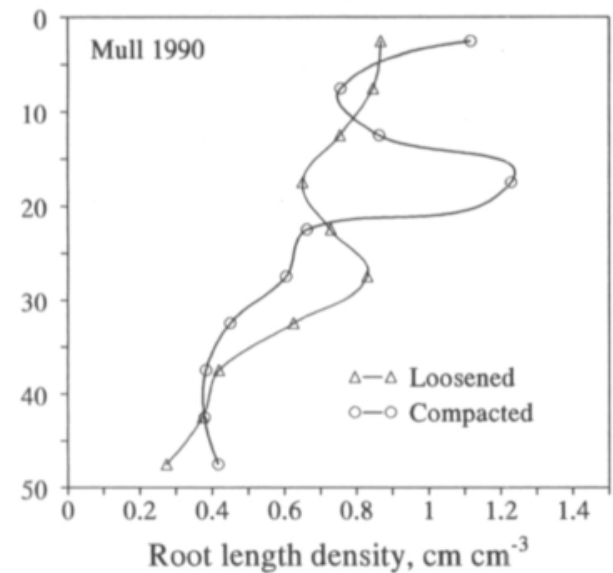

Soil depth, cm

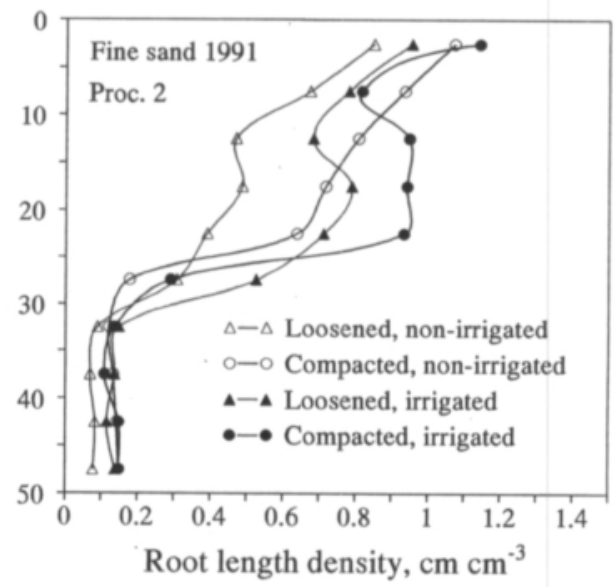

Soil depth, $\mathrm{cm}$

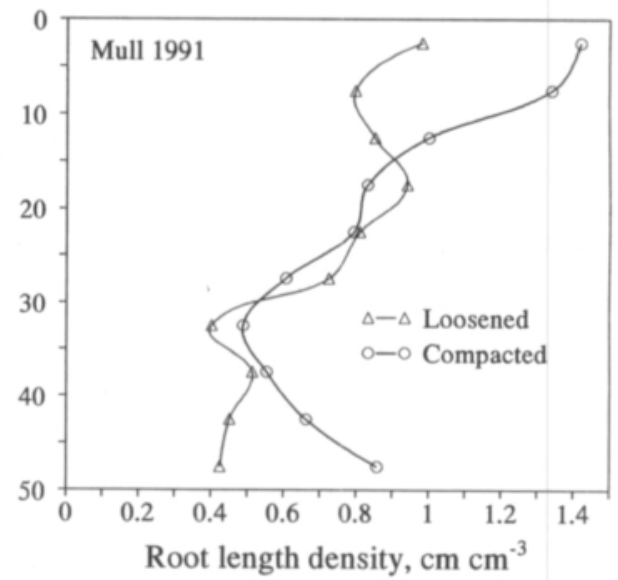

Fig. 39. Fibrous root length density per plant and soil volume in PVC cylinders in fine sand and mull in 1990-1991 as affected by rotary harrowing (Loosened) and three passes of the tractor wheel (Compacted) under non-irrigated $\left(\mathrm{A}_{0}\right)$ and irrigated conditions ( $\mathbf{A}_{1}$ ). The results are from whole sample material in Procedure 1 (Fine sand 1991, Proc. 1), and from sub-samples in Procedure 2 (Fine sand 1991, Proc. 2) and Procedure 3 (Mull 1990, 1991).

HSD $_{\text {oes }}$ for significant differences:

Fine sand in 1991, Proc. 1: $0.14 \mathrm{~cm} \mathrm{~cm}^{-3}$ (at the same A level $\left.0.20 \mathrm{~cm} \mathrm{~cm}^{-3}\right)$ at $10-15 \mathrm{~cm}, 0.19 \mathrm{~cm} \mathrm{~cm}^{-3}\left(0.27 \mathrm{~cm} \mathrm{~cm}^{-3}\right)$ at $15-20 \mathrm{~cm}^{-0.05 \mathrm{~cm} \mathrm{~cm}^{-3}}$ $\left(0.07 \mathrm{~cm} \mathrm{~cm}^{-3}\right)$ at $40-45 \mathrm{~cm}_{0} 0.02 \mathrm{~cm} \mathrm{~cm}^{-3}\left(0.02 \mathrm{~cm} \mathrm{~cm}^{-3}\right)$ at $45-50 \mathrm{~cm}$

Fine sand in 1991, Proc. 2: $0.19 \mathrm{~cm} \mathrm{~cm}^{-3}\left(0.27 \mathrm{~cm} \mathrm{~cm}^{-3}\right)$ at $10-15 \mathrm{~cm}, 0.03 \mathrm{~cm} \mathrm{~cm}^{-3}\left(0.04 \mathrm{~cm} \mathrm{~cm}^{-3}\right)$ at $45-50 \mathrm{~cm}^{-15}$

Mull in 1990: $0.26 \mathrm{~cm} \mathrm{~cm}^{-3}$ at $15-20 \mathrm{~cm}$

Mull in 1991: $0.37 \mathrm{~cm} \mathrm{~cm}^{-3}$ at $0-5 \mathrm{~cm}, 0.43 \mathrm{~cm} \mathrm{~cm}^{-3}$ at $5-10 \mathrm{~cm}$

0-20 cm continued (Fig. 39), even though less statistically significant differences were measured. In 1990, an increase by mull soil compaction was demonstrated at $15-20 \mathrm{~cm}$ (at $10-15 \mathrm{~cm} \mathrm{P}<0.06)$. Similarly, in 1991, a positive effect was found at $0-10 \mathrm{~cm}$.

\section{Root length to tap root weight ratio}

The total root length at $0-50 \mathrm{~cm}$, in relation to tap root biomass, increased by fine sand compaction. Irrigation or mull soil compaction had no significant effect on this ratio (Table 16). No 
Pietola, L.: Effect of soil compactness on the growth and quality of carrot

Soil depth, cm

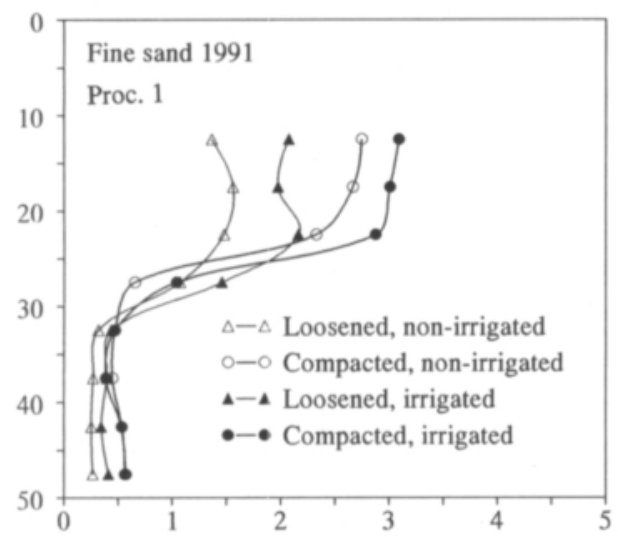

Root length per tap root dry weight, $\mathrm{m} \mathrm{g}^{-1}$

Soil depth, cm

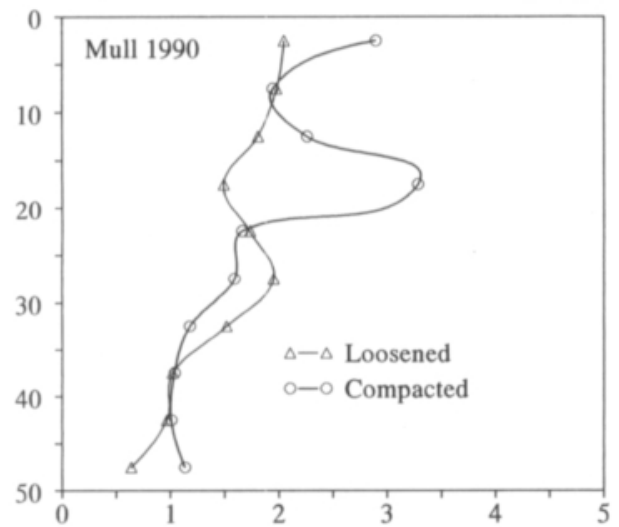

Root length per tap root dry weight, $\mathrm{m} \mathrm{g}^{-1}$
Soil depth, cm

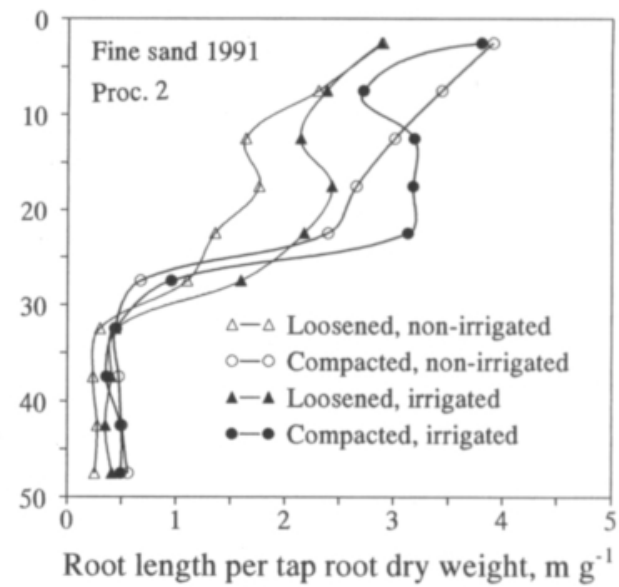

Soil depth, cm

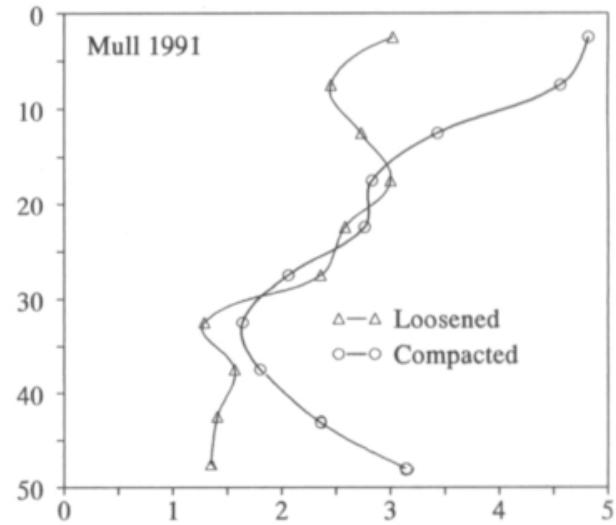

Root length per tap root dry weight, $\mathrm{m} \mathrm{g}^{-1}$

Fig. 40. Fibrous root length in relation to tap root dry weight in PVC cylinders in fine sand and mull in 1990-1991 as affected by rotary harrowing (Loosened) and three passes of the tractor wheel (Compacted) under non-irrigated $\left(\mathrm{A}_{0}\right)$ and irrigated conditions $\left(A_{1}\right)$. The results are from whole sample material in Procedure 1 (Fine sand 1991, Proc. 1), and from sub-samples in Procedure 2 (Fine sand 1991, Proc. 2) and Procedure 3 (Mull 1990, 1991).

HSD $_{0.05}$ for significant differences:

Fine sand in 1991, Proc. 1: $0.53 \mathrm{~m} \mathrm{~g}^{-1}$ (at the same A level $\left.0.75 \mathrm{~m} \mathrm{~g} \mathrm{~g}^{-1}\right)$ at $10-15 \mathrm{~cm}, 0.67 \mathrm{~m} \mathrm{~g}^{-1}\left(0.94 \mathrm{~m} \mathrm{~g}^{-1}\right)$ at $15-20 \mathrm{~cm}^{-0.76 ~ m ~ g-1}\left(1.07 \mathrm{~m} \mathrm{~g}^{-1}\right)$ at $20-25 \mathrm{~cm}^{-}$ $0.19 \mathrm{~m} \mathrm{~g}^{-1}\left(0.26 \mathrm{~m} \mathrm{~g}^{-1}\right)$ at $40-45 \mathrm{~cm}, 0.10 \mathrm{~m} \mathrm{~g}^{-1}\left(0.14 \mathrm{~m} \mathrm{~g}^{-1}\right)$ at $45-50 \mathrm{~cm}$

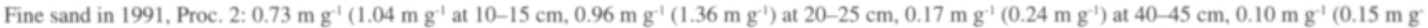
') at $45-50 \mathrm{~cm}$

Mull in 1990: $0.87 \mathrm{~m} \mathrm{~g}^{-1}$ at $15-20 \mathrm{~cm}$

Mull in 1991: $1.78 \mathrm{~m} \mathrm{~g}^{-1}$ at $0-5 \mathrm{~cm}$

clear response of soil irrigation was shown to the ratio in different soil layers (Fig. 40). The increase from 2.2 to $2.8 \mathrm{~m} \mathrm{~g}^{-1}$ by irrigation at $15-20 \mathrm{~cm}$ was significant only based on Procedure 2 .
Fine sand compaction increased root length related to tap root weight at the depths of $10-25 \mathrm{~cm}$ and $40-50 \mathrm{~cm}$. In mull, the ratio increased by soil compaction at the depth of $15-20 \mathrm{~cm}$ in 1990 , and at $0-10 \mathrm{~cm}$ in 1991 (at $5-10 \mathrm{~cm} \mathrm{P}<0.10$ ). 
Vol. 4: 139-237.

Soil depth, cm

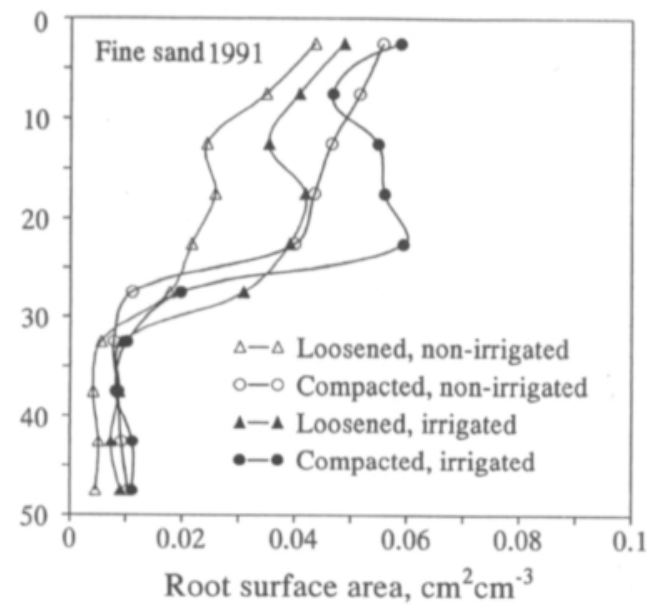

Soil depth, cm

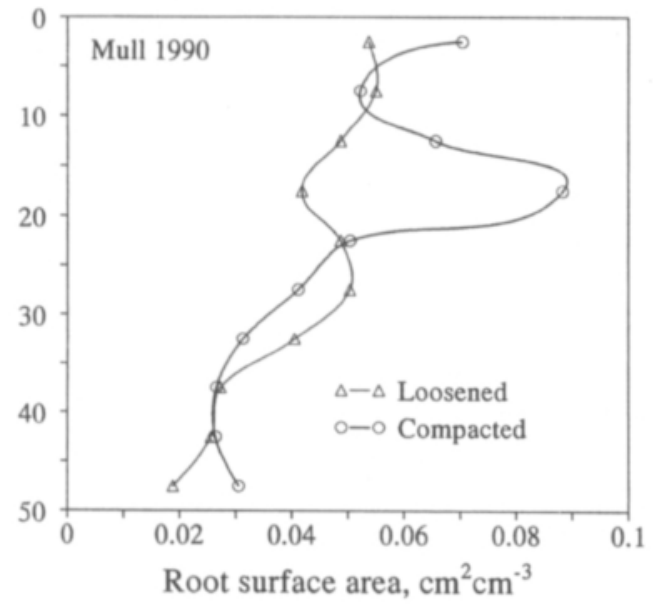

\subsubsection{Distribution of fibrous root surface area}

\section{Root surface area per plant}

The total root surface area increased by irrigation and soil compaction at the depth of $0-50 \mathrm{~cm}$ (Table 16). In fine sand, root surface area in relation to soil volume increased at the soil depth of $15-25 \mathrm{~cm}$ from 0.03 to $0.05 \mathrm{~cm}^{2} \mathrm{~cm}^{-3}$, and at
Fig. 41. Fibrous root surface area $(\pi *$ projected area of root image) per plant and soil volume in PVC cylinders in fine sand and mull in 1990-1991 as affected by rotary harrowing (Loosened) and three passes of the tractor wheel (Compacted) under non-irrigated $\left(A_{0}\right)$ and irrigated conditions $\left(\mathrm{A}_{1}\right)$. The results are from sub-samples in Procedure 2 (Fine sand) and Procedure 3 (Mull).

\section{$\mathrm{HSD}_{\mathrm{ags}}$ for significant differences:}

Fine sand in 1991: $0.011 \mathrm{~cm}^{2} \mathrm{~cm}^{-3}$ (at the same A level $0.015 \mathrm{~cm}^{2} \mathrm{~cm}^{-3}$ ) at $10-15 \mathrm{~cm}, 0.013 \mathrm{~cm}^{2} \mathrm{~cm}^{-3}\left(0.019 \mathrm{~cm}^{2} \mathrm{~cm}^{-3}\right)$ at $15-20 \mathrm{~cm}, 0.016 \mathrm{~cm}^{2} \mathrm{~cm}^{3}$ $\left(0.023 \mathrm{~cm}^{2} \mathrm{~cm}^{-3}\right)$ at $20-25 \mathrm{~cm}, 0.004 \mathrm{~cm}^{2} \mathrm{~cm}^{-3}\left(0.005 \mathrm{~cm}^{2} \mathrm{~cm}^{-3}\right)$ at $40-$ $45 \mathrm{~cm}, 0.002 \mathrm{~cm}^{2} \mathrm{~cm}^{-3}\left(0.003 \mathrm{~cm}^{2} \mathrm{~cm}^{-3}\right)$ at $45-50 \mathrm{~cm}$

Mull in 1990: $0.012 \mathrm{~cm}^{2} \mathrm{~cm}^{-3}$ at $10-15 \mathrm{~cm}, 0.021 \mathrm{~cm}^{2} \mathrm{~cm}^{3}$ at $15-20 \mathrm{~cm}$ Mull in 1991: $0.020 \mathrm{~cm}^{2} \mathrm{~cm}^{-3}$ at $0-5 \mathrm{~cm}, 0.026 \mathrm{~cm}^{2} \mathrm{~cm}^{-3}$ at $5-10 \mathrm{~cm}$

Soil depth, cm

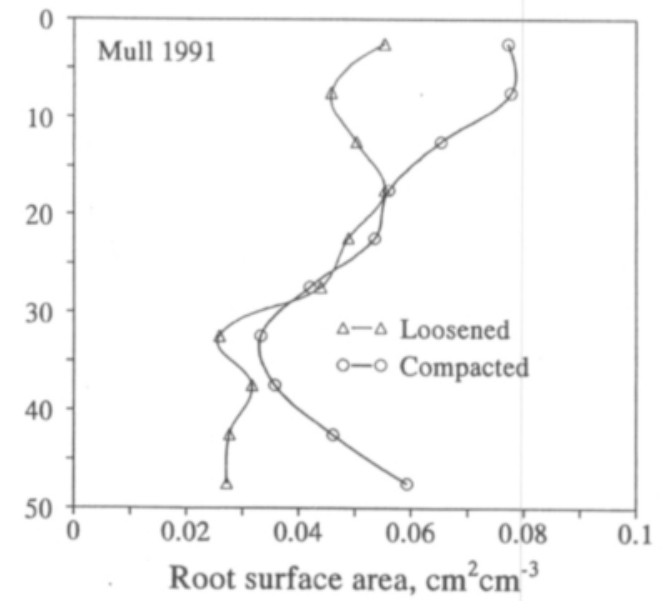

$25-30 \mathrm{~cm}$ from 0.01 to $0.02 \mathrm{~cm}^{2} \mathrm{~cm}^{-3}$ ( $\left.\mathrm{P}<0.06\right)$ by irrigation (Fig. 41). The positive effect of fine sand compaction on root surface area was demonstrated to a depth of $25 \mathrm{~cm}$. The same positive impact was found also in subsoil at the depth of $40-45 \mathrm{~cm}$, with a significant interaction, as the surface area in loose non-irrigated soil was lower than in other soil conditions. In mull in 1990, root surface area increased by soil compaction at $10-20 \mathrm{~cm}$. In 1991, this positive effect was significant to a depth of $10 \mathrm{~cm}$. 
Pietola, L.: Effect of soil compactness on the growth and quality of carrot

Soil depth, cm

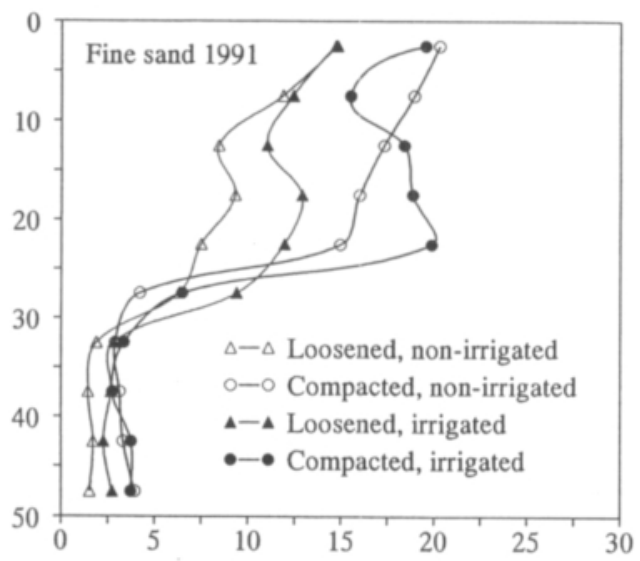

Fig. 42. Fibrous root surface area $(\pi *$ projected area of root image) in relation to tap root dry weight in PVC cylinders in fine sand and mull in 1990-1991 as affected by rotary harrowing (Loosened) and three passes of the tractor wheel (Compacted) under non-irrigated $\left(\mathrm{A}_{0}\right)$ and irrigated conditions $\left(\mathrm{A}_{1}\right)$. The results are from subsamples in Procedure 2 (Fine sand) and Procedure 3 (Mull).

HSD $_{0.05}$ for significant differences:

Fine sand in 1991: $4.1 \mathrm{~cm}^{2} \mathrm{~g}^{-1}$ (at the same A level $5.9 \mathrm{~cm}^{2} \mathrm{~g}^{-1}$ ) at $10-$

$15 \mathrm{~cm}, 4.8 \mathrm{~cm}^{2} \mathrm{~g}^{-1}\left(6.8 \mathrm{~cm}^{2} \mathrm{~g}^{-1}\right)$ at $15-20 \mathrm{~cm}, 5.3 \mathrm{~cm}^{2} \mathrm{~g}^{-1}\left(7.6 \mathrm{~cm}^{2} \mathrm{~g}^{-1}\right)$ at $20-$ $25 \mathrm{~cm}, 1.3 \mathrm{~cm}^{2} \mathrm{~g}^{-1}\left(1.7 \mathrm{~cm}^{2} \mathrm{~g}^{-1}\right)$ at $40-45 \mathrm{~cm}, 0.9 \mathrm{~cm}^{2} \mathrm{~g}^{-1}\left(1.3 \mathrm{~cm}^{2} \mathrm{~g}^{-1}\right)$ at $45-$ $50 \mathrm{~cm}$

Root surface area per tap root dry weight, $\mathrm{cm}^{2} \mathrm{~g}^{-1}$

Soil depth, cm

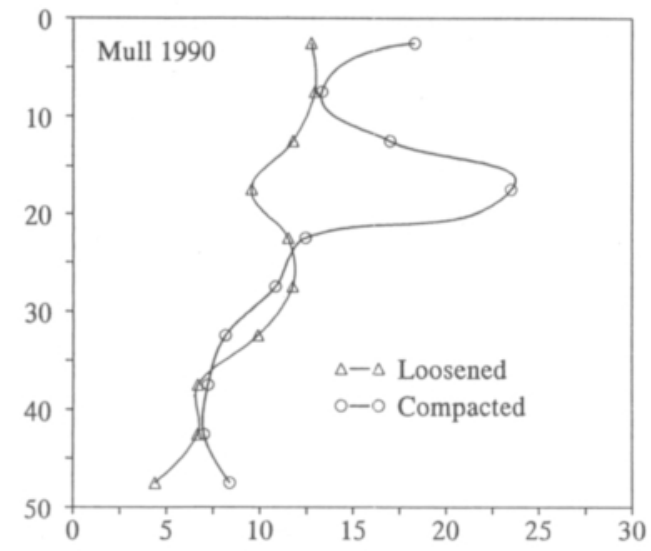

Root surface area per tap root dry weight, $\mathrm{cm}^{2} \mathrm{~g}^{-1}$

Soil depth, cm

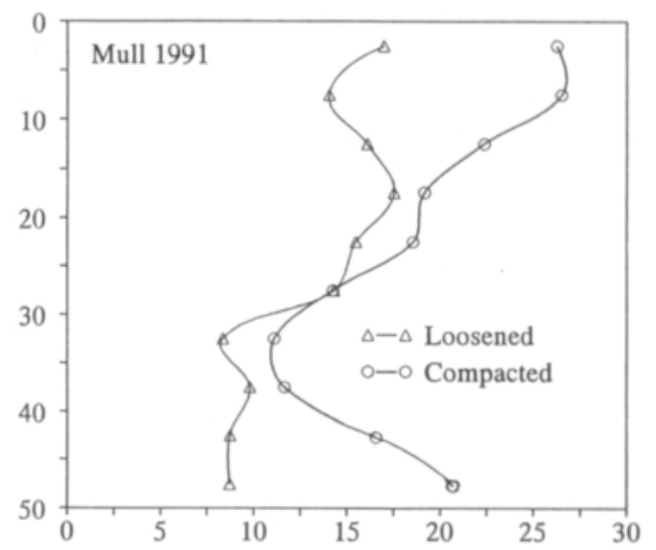

Root surface area per tap root dry weight, $\mathrm{cm}^{2} \mathrm{~g}^{-1}$

\section{Root surface area to tap root weight ratio}

Irrigation increased the surface area to tap root dry weight ratio at $15-20 \mathrm{~cm}$, from 12.7 to $15.9 \mathrm{~cm}^{2} \mathrm{~g}^{-1}$, at $20-25 \mathrm{~cm}$ from 9.7 to $17.4 \mathrm{~cm}^{2} \mathrm{~g}^{-1}(\mathrm{P}<0.06)$, and at $25-30 \mathrm{~cm}$ from 5.3 to $7.9 \mathrm{~cm}^{2} \mathrm{~g}^{-1}(\mathrm{P}<0.10)$. In fine sand, com-

paction had a positive effect on this ratio at the depths of $0-5 \mathrm{~cm}(\mathrm{P}<0.06), 5-10 \mathrm{~cm}(\mathrm{P}<0.10)$, and significantly at $10-25 \mathrm{~cm}$ and $40-50 \mathrm{~cm}$ (Fig. 42). In mull in 1990, the ratio increased by soil compaction at the depths of $15-20 \mathrm{~cm}$ $(\mathrm{P}<0.06)$ and $45-50 \mathrm{~cm}(\mathrm{P}<0.10)$. In 1991, this ratio increased in the two top layers $(\mathrm{P}<0.10)$. 
Vol. 4: 139-237.

Table 17. Percentage of total root length in two dominant diameter classes. $\mathrm{B}_{2}=$ rotary harrowing, $\mathrm{B}_{5}=$ three passes of the tractor wheel, $A_{0}=$ non-irrigated, $A_{1}=$ irrigated.

\begin{tabular}{|c|c|c|c|c|c|c|c|}
\hline \multirow[t]{2}{*}{ Soil } & \multirow[t]{2}{*}{ Year } & \multirow[t]{2}{*}{ Treatment } & \multicolumn{5}{|c|}{ Depth, cm } \\
\hline & & & $0-10$ & $10-20$ & $20-30$ & $30-40$ & $40-50$ \\
\hline & & & & & eter $\approx 0$. & & \\
\hline \multirow{9}{*}{$\begin{array}{l}\text { Fine } \\
\text { sand }\end{array}$} & \multirow[t]{9}{*}{1991} & $\mathrm{~A}_{0} \mathrm{~B}_{2}$ & 94 & 94 & 88 & 83 & 84 \\
\hline & & $\mathrm{A}_{0} \mathrm{~B}_{5}$ & 92 & 86 & 82 & 79 & 78 \\
\hline & & $A_{1} B_{2}$ & 94 & 94 & 88 & 81 & 78 \\
\hline & & $\mathrm{A}_{1} \mathrm{~B}_{5}$ & 91 & 86 & 78 & 71 & 69 \\
\hline & & $\mathrm{HSD}_{0.05}(\mathrm{~B})$ & 2 & 4 & 6 & 4 & 1 \\
\hline & & mean $\left(A_{0}\right)$ & 93 & 90 & 85 & 81 & 81 \\
\hline & & mean $\left(A_{1}\right)$ & 93 & 90 & 83 & 76 & 74 \\
\hline & & mean $\left(B_{2}\right)$ & 94 & 94 & 88 & 82 & 81 \\
\hline & & mean $\left(\mathrm{B}_{5}\right)$ & 92 & 86 & 80 & 75 & 73 \\
\hline \multirow[t]{3}{*}{ Mull } & \multirow[t]{3}{*}{1990} & $\mathrm{~A}_{0} \mathrm{~B}_{2}$ & 81 & 81 & 81 & 81 & 79 \\
\hline & & $\mathrm{A}_{0} \mathrm{~B}_{5}$ & 79 & 74 & 75 & 76 & 73 \\
\hline & & $\mathrm{HSD}_{0.05}$ & n.s. ${ }^{1)}$ & 4 & n.s. & n.s. & 6 \\
\hline \multirow[t]{4}{*}{ Mull } & \multirow[t]{4}{*}{1991} & $\mathrm{~A}_{0} \mathrm{~B}_{2}$ & 88 & 86 & 84 & 81 & 81 \\
\hline & & $\mathrm{A}_{0} \mathrm{~B}_{5}$ & 89 & 78 & 75 & 79 & 73 \\
\hline & & $\mathrm{HSD}_{0.05}$ & n.s. & 6 & 9 & n.s. & 8 \\
\hline & & & \multicolumn{4}{|c|}{ Diameter $\approx 0.40 \mathrm{~mm}$} & \\
\hline \multirow{9}{*}{$\begin{array}{l}\text { Fine } \\
\text { sand }\end{array}$} & \multirow[t]{9}{*}{1991} & $\mathrm{~A}_{0} \mathrm{~B}_{2}$ & 6 & 6 & 11 & 15 & 15 \\
\hline & & $\mathrm{A}_{0} \mathrm{~B}_{5}$ & 8 & 14 & 17 & 19 & 20 \\
\hline & & $\mathrm{A}_{1} \mathrm{~B}_{2}$ & 7 & 6 & 11 & 17 & 20 \\
\hline & & $\mathrm{A}_{1} \mathrm{~B}_{5}$ & 8 & 14 & 20 & 26 & 28 \\
\hline & & $\mathrm{HSD}_{0.05}(\mathrm{~B})$ & 2 & 4 & 5 & 2 & 1 \\
\hline & & mean $\left(A_{0}\right)$ & 7 & 10 & 14 & 17 & 17 \\
\hline & & mean $\left(A_{1}\right)$ & 7 & 10 & 15 & 21 & 24 \\
\hline & & mean $\left(\mathrm{B}_{2}\right)$ & 6 & 6 & 11 & 16 & 17 \\
\hline & & mean $\left(\mathrm{B}_{5}\right)$ & 8 & 14 & 18 & 22 & 24 \\
\hline \multirow[t]{3}{*}{ Mull } & \multirow[t]{3}{*}{1990} & $\mathrm{~A}_{0} \mathrm{~B}_{2}$ & 17 & 17 & 16 & 16 & 18 \\
\hline & & $\mathrm{A}_{0} \mathrm{~B}_{5}$ & 19 & 22 & 21 & 22 & 24 \\
\hline & & $\mathrm{HSD}_{0.05}$ & 2 & 2 & 4 & 4 & 5 \\
\hline \multirow[t]{3}{*}{ Mull } & \multirow[t]{3}{*}{1991} & $\mathrm{~A}_{0} \mathrm{~B}_{2}$ & 12 & 13 & 14 & 17 & 17 \\
\hline & & $\mathrm{A}_{0} \mathrm{~B}_{5}$ & 10 & 20 & 22 & 19 & 25 \\
\hline & & $\mathrm{HSD}_{0.05}$ & n.s. & 5 & 7 & n.s. & 7 \\
\hline
\end{tabular}

${ }^{1)}$ n.s. = not significant

\subsubsection{Fibrous root width}

The fibrous root system consisted mostly of very fine roots. In fine sand, about $90 \%$ of root length in the plough layer consisted of roots of a diameter of around $0.15 \mathrm{~mm}$; in subsoil the corre- sponding figure was $80 \%$ (Table 17). In mull, carrots had more roots over $0.40 \mathrm{~mm}$ in diameter than in fine sand. Soil compaction decreased the amount of the most fine $0.15-\mathrm{mm}$ roots in both soil types, and increased the length of larger roots. Irrigation of compacted fine sand in- 
Pietola, L.: Effect of soil compactness on the growth and quality of carrot

creased further the amount of roots over $0.40 \mathrm{~mm}$ in diameter, especially in subsoil.

By visual observation during the video recording of roots, some roots from compacted and non-irrigated fine sand increased in diameter and were buckled at the depth of $25-40 \mathrm{~cm}$. Below this depth there were some deformities in all treatments. Generally, thicker roots were flattened. Some abnormally vigorous branching was associated with greater root diameters. Otherwise, root branching was uniform. Roots from mull soil had not so clear deformities as sandy soil roots, except for some dead roots at the depth of $30-35 \mathrm{~cm}$, mainly in $\mathrm{B}_{2}$ treatment, suggesting root death under drier soil conditions of the loosened soil media.

Based on visual observations on the carrot root morphology during the video recording (roots on the tray) and during the image analyses (root images on the computer screen), the image analysis approach could determine accurately the length and width of the fibrous root system. The length of fine carrot roots $\leq 0.15$ $\mathrm{mm}$ in diameter, which were not detected by the image processing system, remained below $5 \%$. 


\section{Discussion}

\section{I Effect of soil loosening, compaction and irrigation on soil physical growth factors}

Soil loosening resulted in a reduced supply of stored soil water for non-irrigated soils. In comparison with compacted soils, volumetric water contents in loosened soils were lower at matric potentials around $-10 \mathrm{kPa}$, recorded in plough layer before carrot growth. This was supported by the lower volume of small and medium-size pores in loosened soils. Additionally, in both clay $(\mathrm{P}<0.05)$ and mull fields $(\mathrm{P}<0.10)$ the gypsum block recordings were the highest in untreated $\mathrm{B}_{3}$ plots, despite a high growth in this treatment. This appeared to be a response to an efficient water uptake by plants under compacted soil conditions (Lipiec et al. 1988, 1992) and low unsaturated hydraulic conductivity (Kemper et al. 1971, Voorhees et al. 1979) as a result of the lower volumetric soil water contents in loosened soils (Mehta et al. 1994).

Also Domzal and Hodara (1992) demonstrated this positive effect of soil compactness on volumetric soil water contents for sandy and loamy soils at matric potentials between $-1 \mathrm{kPa}$ and $-50 \mathrm{kPa}$, and Reicosky et al. (1981) for a clay loam soil at a matric potential below $-10 \mathrm{kPa}$. Further, the results of Boone et al. (1978) on sandy soil (10\% clay, $2.3 \%$ organic matter) are well in agreement with the findings of the present study. At a matric potential of $10 \mathrm{kPa}$, a loose bed held less water on volume basis $(31 \%)$ than a soil compacted once or four times (axle load $5.6 \mathrm{Mg}$, moisture slightly below field capacity at compaction), with water contents of $34 \%$ and $33 \%$, respectively. According to Mehta et al. (1994), this decrease of the volumetric water content in fine sand decreased its unsaturated hydraulic conductivity.
The low volumetric water content in non-irrigated soils, especially in loose media, had adverse consequenses for plant growth. In dry soil, a plant loses its ability to expand the root system, as exemplified by Smucker at el. (1991) who reported root branching of maize to decrease when soil water potentials dropped below $-100 \mathrm{kPa}$. The moisture stress-induced root system maintains turgor less effectively which reduces the root elongation rate (Pritchard et al. 1990a b, ref. Tardieu 1994). Moreover, as soil moisture is about $2 / 3$ of field capacity, signals from the roots (e.g. abscisic acid) have almost immediate effects upon shoot growth, as leaf conductance and the rate of net photosynthesis decrease (Turner et al. 1985, Zhang and Davies 1989). Soil water contents retained by the smaller pores, which were clearly increased by soil compaction, appeared to be more available to roots growing in that region of the soil profile.

The field experiments were established under moist soil conditions for an efficient soil compaction. At the time of compaction, however, some water at a matric potential over $10 \mathrm{kPa}$ was found, decreasing the maximum efficiency of compaction (Akram and Kemper 1979). The impact of tractor wheel traffic on increasing soil dry bulk density and penetrometer resistance was confirmed to depths of $25-30 \mathrm{~cm}$ and it is consistent with data published by Voorhees et al. (1978), Aura (1983) and Domzal et al. (1992) for different mineral soil types. Unlike fine sand or clay, the effect of one pass with a mediumsize tractor was remarkable to soil depths of 30$35 \mathrm{~cm}$ in mull field, i.e $0.15 \mathrm{~g} \mathrm{~cm}^{-3}$ as compared with the rotary harrowed $\left(\mathrm{B}_{2}\right)$ treatment. Obviously, this was the result of a low carrying capacity ( $\rho_{d}$ only $0.5 \mathrm{~g} \mathrm{~cm}^{-3}$ for subsoil) and high clay content of the organic field (Horn 1988). In this soil layer of $0-30 \mathrm{~cm}$, the physical soil properties are crucial for plant growth, since root systems of annual plants are mainly located at this soil layer (Ouwerkerk and Noordwijk 1991). 


\section{AGRICULTURAL SCIENCE IN FINLAND}

Pietola, L.: Effect of soil compactness on the growth and quality of carrot

Penetrometer resistances were different and depended on soil type, water content and bulk density. These data agree with Gerard et al. (1982). The critical limit of penetrometer resistance for plant growth of approximately $2 \mathrm{MPa}$ (Martino and Shaykewich 1994) was measured in mull soil only in the dry subsoil after three tractor passes $\left(\mathrm{B}_{5}\right)$. In fine sand of higher internal friction, this limit was exceeded both in non-compacted and compacted subsoil under various soil moisture conditions, but in the plough layer only after three passes by the tractor wheels. In cohesive clay soil, one pass by the tractor was enough to reach this critical limit in the dry plough layer. The increasing effect of soil drying on mechanical impedance was shown clearly in fine sand, in agreement with Lipiec et al. (1990), as the change in dry bulk density of $0.25 \mathrm{~g} \mathrm{~cm}^{-3}$ increased the penetrometer resistance by $2.0 \mathrm{MPa}$ at a moisture of $50 \%$ of plant-available water, and by $0.7 \mathrm{MPa}$ near field capacity. The relatively similar change in dry bulk density of $0.15 \mathrm{~g} \mathrm{~cm}^{-3}$ increased the penetrometer resistance in dry mull soil by $0.9 \mathrm{MPa}$ and by $0.6 \mathrm{MPa}$ in moist mull soil, indicating that organic matter in mull lowered the cohesive forces of the clay fraction. This is supported by O'Sullivan (1992) who reported minor effects of soil compaction on the tensile strength (Dexter 1988) in soils of higher organic matter content. Soil penetrometer resistance was better explained by soil dry bulk density than by soil water content since the effect of soil moisture was more marked at high bulk densities, as shown also by Ayers and Perumpral (1982).

Based on macroporosity, soil aeration limited plant growth only in compacted clay soil, although the volume of macropores (equivalent diameters over $30 \mu \mathrm{m}$ ) was most affected by mechanical treatments in all soil types. This result is well exemplified by Eriksson (1976) and Aura (1983) in clay soil, and by Lipiec and Tarkiewicz (1984) in sandy and loamy soils. In the plough layer of both fine sand and mull fields, the volume of macropores was over $15 \%$ after three passes with the tractor, suggesting that soil aeration was not severely limited, as when several passes by a $3 \mathrm{Mg}$ tractor decreased the clay soil macroporosity in the plough layer to below $10 \%$. Air-filled porosity $<10 \%$ characterized definitely deficient aeration (Glinski and Stepniewski 1985).

In mull soil, at the depth of $2.5-7.5 \mathrm{~cm}$, the pore space occupied by pores below $30 \mu \mathrm{m}$ in diameter increased by as much as 12 percentage units by three tractor passes, suggesting better water retention for a compacted top layer than for a loosened soil. Similarly, in clay field the change was 5 percentage units, in fine sand even less. This agrees with Jorge et al. (1992) who reported that compaction of wet sandy soil $(6 \mathrm{Mg})$ increased the pore space with pores of a diameter below $50 \mu \mathrm{m}$ by 5 percentage units as compared with uncompacted soils of a microporosity of $18 \%$. The plant-available water capacity, however, remained less affected because the main part of the increase in pores of a diameter below $30 \mu \mathrm{m}$ was due to the increase in small pores.

Soil air composition was affected remarkably by soil compaction at the depth of $15 \mathrm{~cm}$ only in clay soil where, at the beginning of the growing period and under wet soil conditions, soil oxygen content decreased by almost 5 percentage units by three tractor passes as compared with non-compacted soil. The increase of carbon dioxide content was 3 percentage units. This is well in agreement with the changes of soil air composition by soil compaction at the depth of $25 \mathrm{~cm}$ (Simojoki et al. 1991) in high axle-load studies on Finnish clay soil. In the present study, clay soil dried up soon, and in mid-June the effect on soil air composition had already disappeared. Shrinking of clay soil caused large cracks, which explains why air composition was not affected by soil compaction even in irrigated plots. Thus, some hollow spaces were sufficient to maintain a good aeration and to compensate for the decrease of macropores by soil compaction, as was shown by Frede (1985). In early season, the change in soil air composition caused by soil compaction was smaller in fine sand than in clay soil, which is expected based 
Vol. 4: 139-237,

on the relatively high macroporosity of compacted fine sand (over 15\%).

In the present study, the lowest oxygen contents were measured in mull soil at the depth of $30 \mathrm{~cm}$. At the beginning of the growing period, the oxygen content was as low as $11 \%$ after three tractor passes. The soil carbon dioxide content increased respectively from $1 \%$ to $6 \%$. According to Simojoki et al. (1991), such a low oxygen content was measured only at the depth of $50 \mathrm{~cm}$ in clay soil. The lower values for soil oxygen combined with greater carbon dioxide contents in compacted soils appeared to be a response to the higher biological activity with increasing soil dry bulk density (Malicki et al. 1991). In early summer, when plant growth was slow, the effect of mull compaction was much smaller in drier surface soil (depth $15 \mathrm{~cm}$ ) than in subsoil $(30 \mathrm{~cm})$. Later, both soil moisture and soil air composition were similar at both depths. Under these quite dry conditions, not even the vigorous carrot growth at the end of July changed the soil air composition, as was the case in the moist fine sand.

The changes in soil physical growth factors discussed above are consistent with the theory presented in Figure 1 (p. 147). At the depth of $10-20 \mathrm{~cm}$, where soils were compacted the most, the average gravimetric D value (Håkansson $1990)$ for narrow ridges $\left(B_{1}\right)$ and untreated soil $\left(\mathrm{B}_{3}\right)$ was 80 in both fine sand and mull, being only 77 for rotary harrowed soil. These low D values resulted in a low water supply. For all soil types, three tractor passes led to a $\mathrm{D}$ value of 92-94, with critical penetrometer resistance in dry mineral soils, or poor aeration in wetter mull soils of high clay contents. Possibly because of a high clay content of mull (over $80 \%$ ), the D value of this soil type was affected quite similarly to mechanical treatments as compared with mineral soils. After one pass by the tractor, however, the D value was 87 for mull and only 83 for fine sand, which reflects a weaker applicability of D value to organic soils (Håkansson 1990).

\subsection{Effect of soil physical growth factors on carrot growth and yield quality}

Only clay soil was compacted to the extent of inhibiting highly carrot growth. Also in loosened clay, the biomass accumulation in tap roots was impaired in non-irrigated plots, indicating a moisture stress when soil compactness was very low. Only shallow harrowing (to the depth of $5 \mathrm{~cm}$ ) of autumn ploughed clay soil was enough to create an optimal state of compactness for carrot tap root yield $(D=82)$. This is less than is needed for small grains (Håkansson 1990). In fine sand and mull, the optimum soil compactness for carrot tap root yield was not clearly determined, as the growth response varied in different years in agreement with Taksdal (1984) on sandy soil. Even if the mineral component of mull soil was mainly clay (over $80 \%$ ), soil compaction did not affect adversely tap root growth like in clay field. Consequently, the high organic matter content (around 20\%) in the mull soil eliminated significantly the effects of clay fraction. This is well in agreement with White (1978) and Millette et al. (1981) according to which different organic soil preparations have no or only a slight effect on carrot yield.

During the long dry period of 1990 did fine sand compactness affect the carrot growth rhythm. Then, as fine sand dried up, its penetrometer resistance exceeded the critical growth limit of 2-2.5 MPa (Martino and Shaykewich 1994), delaying the development of tap root growth in the treatment of three passes. In irrigated plots with lower penetrometer resistances, this decrease of growth by soil compaction was not so severe. This favourable effect of water applications was still shown at harvest, but less than earlier in the summer. Thus, in terms of final yields, the positive influence of water applications on carrot growth remained low in all experimental years, regardless of the different timing of dry periods. This agrees with Aura 
Pietola, L.: Effect of soil compactness on the growth and quality of carrot

(1985) who showed no effect of irrigation on tap root yield during one week of drought at the end of July.

As compared with tap root growth, final shoot yield was affected less by soil compactness, in agreement with Olymbios and Schwabe (1977), White and Strandberg (1979) and Agung and Blair (1989) for other cultivars. Early shoot growth was, however, affected, as the growth was the weakest in loose non-irrigated soils with a moisture stress. Unlike in fine sand, the shoot growth was retarded also in compacted and irrigated clay because of the poor aeration. The lower emergence and seedling development in loose mull, as compared with compacted mull, have been demonstrated also in other organic soils (Olymbios and Schwabe 1977, Strzalka 1990). The low carrot yield in narrow ridges in 1990 can be explained by low plant density caused by drought and very low night temperatures (as low as $-8^{\circ} \mathrm{C}$ ) during the most sensitive shooting stage. According to Heikinheimo et al. (unpublished data), the lowest soil temperatures by night were measured from ridges in the mull field.

Although early growth was promoted by partial soil compaction, increased soil compactness affected the external quality of tap roots adversely during the most vigorous radial growth in dry soil of high penetrometer resistance. This was shown clearly in 1990 in the fine sand experiment where carrots were short, conical (low cylindricality index) and had a low length to diameter ratio in compacted treatments. The changes in root shape diminished in late season because of the decreasing effect of precipitation on soil mechanical impedance. However, the alterations in root length sustained throughout the growing season. Tap root length was affected relatively more than the diameter in the present study in agreement with White (1992). The decreasing effect of high soil wetness on tap root length (Millette 1983, White 1992) was shown only by the late water applications in 1991 .

Poor macroporosity clearly affeceted tap root cylindricality. In three times compacted clay soil, where the volume of macropores $(>30 \mu \mathrm{m})$ decreased below $10 \%$ at the depth below $5 \mathrm{~cm}$, car- rot shape was the most conical. The cylindricality index was only 0.59 . This is well in agreement with Olymbios and Schwabe (1977) for carrots grown in a soil of macroporosity of $8 \%$ and a dry bulk density of $1.45 \mathrm{~g} \mathrm{~cm}^{-3}$. In different soil types and years, root cylindricality of loose soil carrots was slightly below 0.75 , which was consistent with Agung and Blair (1989).

Root splitting, branching, and size growth were affected by soil compactness the most in clay and least in mull. This was a response to the most altered physical growth factors in clay soil where the increase of soil compactness increased root splitting from 5\% (on weight basis) in narrow ridges to over $35 \%$ in three times compacted clay soil under non-irrigated conditions. Splitting decreased by irrigation in clay in all other mechanical treatments except one tractor pass. This can be explained by the assumption that root growth pressure exceeded soil mechanical impedance lowered by irrigation, making diameter growth possible, but at harvest this high growth pressure was shown as root splitting. That year (1989), root splitting was very common at harvest. In three times compacted clay soil, root diameter growth was greatly restricted below the layer of secondary tillage (upper $5 \mathrm{~cm}$ ) even in irrigated soil. This was shown by many small tap roots $(<50 \mathrm{~g})$ grown in three times compacted and irrigated clay (50\% of non-branched and non-split roots).

Soil mechanical treatments or irrigation did not have as remarkable an effect on root branching as on splitting. Branched carrots were found mostly in non-compacted or non-loosened soil $\left(B_{3}\right)$, except for 1991 when carrots were branched the most in compacted soil. The number of branched carrots was very low in 1990 when plant density was higher than in the other years. This agrees with Dowker et al. (1974) who reported that deformed carrots are most abundant at a low plant density. For all soil types on average, the largest number of medium-size (50-250 g) roots with no splitting or branching was produced in untreated plots $\left(B_{3}\right)$. The amount of small carrots increased by compaction, but this effect could be diminished by late irrigation with decreasing penetrometer resistance. 
Vol. 4: 139-237.

While the tap root size was affected, the response of carrot internal quality to soil compactness was minor. The concentrations of quality components in the tap roots grown in loose soil were lower or similar to those in carrots grown in partially compacted soil, except juice content which decreased by soil compaction. The concentrations had a moderate negative relation to final root size, indicating that the restricted vegetative growth in compacted soil had no harmful effects on internal quality. The high sugar and carotene contents even in compacted clay soil can be explained by the strong influence of genetic factors on carrot chemical quality (Nilsson 1984) and is also well in agreement with Banga (1963) who reported that the balance between tap root vegetative growth and root ripening (diameter growth and increase of colour intensity) is controlled mainly by temperature and plant density, and only to a smaller extent by soil moisture and oxygen content in soil air.

Clay soil compaction had a remarkable increasing influence on carrot dry matter and crude fibre content. In three times compacted clay soil, crude fibre content was even higher in irrigated plots than in non-irrigated plots. This may be explained by lower cell enlargement in compacted soil when irrigated because of poorer aeration. According to Aubert et al. (1979), both juice and crude fibre contents are good indicators of root firmness. Thus, a high quantity of juice refers to a fragile tap root, as roots with a high crude fibre content are firm, like tap roots in compacted clay soil.

Additionally, the high crude fibre or low juice content suggests high maturity for carrots grown in compacted clay, as tap root firmness indicates ripeness of carrots, as do also carotene, sugar and dry matter contents (Fritz and Habben 1974). This is in agreement with Banga and Bruyn (1964), who reported that narrower growth limits reduce vegetative growth and favour earlier ripening, including carotenogenesis. Carrots grown in compacted clay soil contained at least as much carotenes (alfa and beta carotenes together) as did carrots grown in mineral soils on average, and much more than reported by Evers (1989a) for cv. Nantes Duke 120 days after sowing. This appears to be a response to the smaller cell size in tap root tissue accumulated in compacted clay, as determined by the increase of crude fibre content (cell walls). As carotene concentration increases in the individual cell (Banga and Bruyn 1964), the carotene content in tap root tissue reached these high levels in compacted soil, even if the roots were small and their shape was very peculiar.

Also the sugar analysis showed higher biochemical maturity in carrots grown in compacted soils. As the total sugars are mainly sucrose in biochemically mature carrots (Phan and Hsu 1973, Fritz and Weichmann 1979), the higher sucrose level in compacted fine sand suggested earlier ripening for carrots in compacted soil. The slightly faster ripening was confirmed by juice dry matter content, closely related to carrot sugar content (Aura 1985), which increased most along the season in compacted soil.

Weather conditions, however, affected the internal quality more than did soil compactness. As dry matter content in tap root tissue and in juice increased with advancing season, soil moisture at sampling time was closely related to dry matter content and juiciness. In mull, the dry matter content did not increase much during the cool late summer in 1990 , and the low dry matter content at harvest showed that tap roots were not yet ripe (Fritz and Habben 1974). The lowest carotene content was recorded from these carrots, also indicating incomplete carrot growth (Banga et al. 1955, Phan and Hsu 1973). The highest carotene content in compacted mull showed that carotene synthesis was a little more advanced under compacted soil conditions. This appears to be a response to the larger size of the foliage with higher photosynthetic capacity (Banga and Bruyn 1964). In the same year of 1990 , carrots grown in fine sand contained almost three times more carotenes than those grown in mull. In 1991, after a very cool May and July, the season was warm and carotenes in mull soil carrots almost reached the level reported for fine sand. Shooting and plant development were more vigorous in fine sand, which explains 
Pietola, L.: Effect of soil compactness on the growth and quality of carrot

the differences between these soil types reported also by Gormley et al. (1971).

During three years, the water applications had both a positive, a negative and no effect on carotene concentrations in sandy soil. This indicates the great importance of other weather conditions in carotene synthesis, as temperature as well as timing and length of drought period varied a lot between seasons. This agrees with Simon et al. (1982) who reported that of the genotype, soil and climate effects, climate had a major influence on carotene levels. However, neither soil type nor experimental year affected the sugar contents, indicating less importance of soil type and weather conditions in sugar synthesis than was measured for carotenes. This is supported also by Simon et al. (1982) who showed greater genetic and less environmental variation for sucrose and total sugars. However, the sucrose contents of the present study were slightly lower than reported by Evers (1989b) for the same cultivar.

\subsection{Role of fibrous root system in carrot response to soil compactness}

The high biochemical maturity (carotene and sugar contents) of tap roots in partially compacted soils is in accordance with high length and surface area of fibrous root system observed under compacted conditions. The differences of soil compactness had a clear effect on the distribution of the whole root system. Tap root biomass in PVC cylinders was accumulated mainly in the upper $10 \mathrm{~cm}$ of the compacted soil, but significant growth was observed also at the depth of $10-20 \mathrm{~cm}$ in loose soil. In compacted media the biomass tended $(\mathrm{P}<0.10)$ to accumulate more in the soil surface if irrigation was performed. This is in agreement with irrigation studies on carrot (Dragland 1978) where the drought of early summer increased tap root length and improved the shape.
Fibrous root growth was, on the other hand, stimulated by partial soil compaction to a depth of $30 \mathrm{~cm}$, especially under non-irrigated conditions. The total root length per plant was lower in fine sand than in mull, the maximum root length being $200 \mathrm{~m}$ for fine sand in agreement with Agung and Blair (1989), and $300 \mathrm{~m}$ for mull. This high root length in partially compacted soils was mainly due to better soil water supply, as the root length in loose and irrigated soil was rather similar to that in compacted and non-irrigated soil. This agrees with Prathapar et al. (1989) who showed decreased root length density in the weak unsaturated hydraulic conductivity. The vigorous branching caused by high mechanical impedance (Pietola 1991) could be another reason for the high fibrous root length in moderately compacted fine sand. Additionally, the lower soil water content in loosened soil during plant emergence retarded the early shooting, too. According to Aguirrezabal et al. (1994), this affected the root elongation rate because it is closely related to intercepted light under field conditions, i.e. shoot growth.

To a depth of $30 \mathrm{~cm}$ the root length density of carrot fibrous roots $\left(0.5-1 \mathrm{~cm} \mathrm{~cm}^{-3}\right.$ per plant) was in the range of other dicotyledonous species (Noordwijk and Brouwer 1991) which also have more roots penetrating to depth in both compact $\left(\rho_{d}=1.50 \mathrm{~g} \mathrm{~cm}^{-3}\right)$ and loosened soil $\left(\rho_{\mathrm{d}}=1.33 \mathrm{~g} \mathrm{~cm}^{-3}\right.$ at $\left.10-30 \mathrm{~cm}\right)$ than monocotydelons (Materechera et al. 1993). Like barley root length (Xu and Juma 1994), the carrot fibrous root length followed a similar trend as root dry weight. In loose fine sand at the depth of $15-25 \mathrm{~cm}$, however, the root dry weights were relatively slightly lower than the root length. This was caused by the smaller root diameter in loose, non-irrigated soil than in compacted profiles. The increasing percentage of thicker roots caused by increasing dry bulk density with no water limitation is in accordance with Huang (1990) who studied Phaseolus vulgaris L. The diameter increase caused by soil compactness was not recorded in mull of much lower dry bulk density. Since the major part of roots $(75 \%$ in mull, $85 \%$ in fine sand) were still included in the 
Vol. 4: 139-237.

lowest width class of around $0.15 \mathrm{~mm}$ in compacted soil (as compared with $80 \%$ in loose mull soil and $90 \%$ in loose fine sand), the relative differences between fibrous root dry weight, length and root surface area were minimal.

The high length of the smallest roots (diameter $0.15 \mathrm{~mm}$ ) is beneficial for carrot plant, as fine roots perform better mechanically in soil than larger roots. A model of Richards and Greacen (1986) predicts lower mechanical impedance for finer roots. Further, Barley et al. (1965) showed that wheat roots of a diameter of $0.3 \mathrm{~mm}$ grew better in identical soil than pea roots of a diameter of $1.0 \mathrm{~mm}$. Plant species with root systems consisting of very fine roots also have larger specific root surface areas (surface area divided by root weight). In the present study, the specific surface area of a carrot fibrous root system averaged $1500-2000 \mathrm{~cm}^{2} \mathrm{~g}^{-1}$. Because of the root storing in ethanol for 2-6 months, the weight loss makes this specific surface area slightly overestimated. The high specific root surface area suggests a low requirement of carbon per unit of root surface area and efficient water and nutrient intake for the very thin fibrous root system of carrot (Barber and Silverbush 1984, Eissenstat 1992). A root length to weight ratio of 250 $350 \mathrm{~m} \mathrm{~g}^{-1}$ of the carrot root systems produced by this study effectively compares with the length to weight ratio of other species (Jones et al. 1991).

As the carrot fibrous root system extends to a depth of $60 \mathrm{~cm}$ (Schuurman and Shäffner 1974) or even deeper (the present study), it was shown to be the most abundant in the upper $30 \mathrm{~cm}$. Thus, this relatively large root system consisting of mostly very fine roots in the most fertile soil horizon may be a reason for the insensitivity of carrot yield to water and nitrogen supply in earlier Finnish studies (Lehtinen 1984, Aura 1985, Vuorinen and Takala 1987, Evers 1988) and the ability of carrot plant to grow on soils low in available phosphorus (Itoh and Barber 1983a). This is not related to root hairs, because carrot root hairs are short $(0.04 \mathrm{~mm})$ and have a very limited role in nutrient uptake (Itoh and Barber 1983a, b, Barber and Silberbush 1984).
Further, the ability to obtain water and nutrients from soil increases with increasing root to soil contact (Veen et al. 1992) which, in turn, increases by reducing soil porosity (Kooistra et al. 1992). As soil porosity, especially macroporosity, decreased and root length density and surface area increased with greater soil compaction, the root system of the present study had greater absorption potentials under compacted soil conditions than in loose soil. As more fibrous roots of larger diameters were found in compacted soil with no water deficit than in loose or non-irrigated soil, soil strength was low enough for optimum root length growth but high enough for root diameter growth to attain better root to soil contact. This could explain why soil compaction affected slightly positively the internal quality components of tap root tissue. Moreover, based on the high sugar and carotene contents, fibrous root permeability or conductance appears not to be adveresely affected by the partial soil compaction applied in the present study.

Also Agung and Blair (1989) found in a pot experiment that moderate compaction $\left(\rho_{b}\right.$ increase from 1.25 to $1.40 \mathrm{~g} \mathrm{~cm}^{-3}$ ) increased significantly fibrous root length of ripe carrots in loamy sand in a low water regime with increasing shoot biomass. More intensive compaction $\left(\rho_{b}=1.55 \mathrm{~cm}^{-3}\right)$ did not, however, affect carrot root length, whereas the most intensive compaction $\left(\rho_{\mathrm{b}}=1.70 \mathrm{~g} \mathrm{~cm}^{-3}\right)$ decreased root length. Under the field conditions of the present study, root length was not decreased by soil compaction in any soil, not even in clay soil. This was due to lower maximum soil compactness (relative dry bulk density) than in the pots in Agung and Blair (1989). Obviously, the existence of biopores and cracks in the natural soil profiles of our PVC cylinder studies favoured the penetration of fine roots. This was most distinct in clay soil where the root dry weights remained the same in loosened and compacted soils.

In PVC cylinders, the soil volume was 6.5 times higher than in the pots (diameter $15 \mathrm{~cm}$, height $31 \mathrm{~cm}$ ) reported by Agung and Blair (1989) for three carrots in loamy sand. In these 
Pietola, L.: Effect of soil compactness on the growth and quality of carrot

two soil volumes, the maximum total root length of a carrot fibrous root system was the same, 180-200 m per plant. In the pot experiment 153 days after sowing, the maximum root length per plant was $180 \mathrm{~m}$ in a high water regime in a dry bulk density of $1.40 \mathrm{~g} \mathrm{~cm}^{-3}$, while a lower root length, $80 \mathrm{~m}$ per plant, was observed in low water treatment in a dry bulk density of $1.25 \mathrm{~g} \mathrm{~cm}^{-3}$. In the present study, the maximum root length per plant was $200 \mathrm{~m}$ in fine sand, also in a high water regime (irrigated soil) with a dry bulk density of $1.43 \mathrm{~g} \mathrm{~cm}^{-3}$ in the plough layer. The lowest length, $120 \mathrm{~m}$, was observed in non-irrigated soil with a dry bulk density of $1.22 \mathrm{~g} \mathrm{~cm}^{-3}$ (gravimetric analyses).

Agung and Blair (1989) did not measure the root length distribution inside artificial soil profiles $31 \mathrm{~cm}$ high, and reported total root lengths only. For small grains, root length density was negatively affected by soil compaction (Willat 1986), but it could also be increased by soil compaction to depths of $10 \mathrm{~cm}$ (Lipiec et al. 1992). This emphasizes the importance of root length analysis at various depths within the soil profile, specifically in natural field soil profiles used for field crops. This study showed that root length distribution of carrots was close to the root distribution pattern of wheat, sugarbeet and onion where differences in root length density between traffic intensities were generally small (Ouwerkerk and Noordwijk 1991). Carrot fibrous roots showed a fairly regular root distri- bution in the subsoil, but in the surface soil ( 0 $30 \mathrm{~cm}$ ) where the roots were the most abundant, the root length, dry weight and distribution of surface area varied between seasons and among soil types. The lower root quantity in fine sand in 1990 (170 days after sowing) as compared with 1991 (150 days after sowing) could be due to the different weather conditions but also to delayed sampling and root turnover (death).

As the dry weight, length and surface area of fibrous roots were determined in relation to tap root biomass on dry weight basis, the differences in these values between soil compactness were same or slightly increased. This is of great importance for the maturation of the tap root tissue, as the fibrous roots of a carrot have a much more significant role in carrot growth than the tap root (Benjamin and Wren 1978, 1980). Consequently, the importance of carrot effective fibrous roots in explaining the minor differences of carrot internal quality caused by soil compactness is obvious. However, absorption of ions and water should also be investigated, as the root absorption potential also depends on root conductance. Since large quantities of carbon are located in the tap roots of carrots, this supply could serve as a reservoir for the growth and regrowth of fibrous root systems. Whether the quantities of fibrous roots which are produced under compacted soil conditions are the result of reallocated carbon from the tap root, warrants further investigation.

\section{Conclusions}

Selected soil physical properties and carrot external quality were affected by soil compactness (Fig. 43). Among fine sand, clay and mull, optimum soil compactness for carrot yield was observed most clearly in clay field.

The internal quality of carrots appeared to be unaffected, or was slightly improved by soil compaction. The growth stage, weather condi- tions and soil type had a greater impact on internal quality factors than had soil compactness.

The carrot root system consisted mostly of very fine roots (diameter around $0.15 \mathrm{~mm}$ ) and had a total length of $150-200 \mathrm{~m}$ to a depth of $50 \mathrm{~cm}$. Partial soil compaction and irrigation increased the fibrous root length and surface area in natural soil profiles to a depth of $30 \mathrm{~cm}$. The 
Vol. 4: 139-237.

Soil

dry bulk density, microporosity, unsaturated water content $(v / v)$, penetrometer resistance.

aeration.

\section{Carrot shoot}

weight.

\section{Carrot tap root}

weight, branching

cylindrical index, length,

juice content.

splitting,

dry matter and crude fibre content.

diameter,

sugar and carotene content.

\section{Carrot fibrous root}

dry weight, length, surface area..
Soil compactness, D

... 80 $90 \ldots$

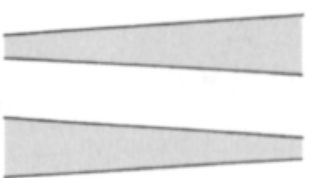

Fig. 43. Schematic summary of changes in physical soil parameters and morphological and physiological carrot parameters with changing soil compactness (D) (Håkansson 1990) at a soil depth of $0-30 \mathrm{~cm}$.

large absorption potential of fibrous root system explains the minor differences of carrot internal quality caused by soil compactness.

A shallow harrowing of ploughed land is suggested as the maximum loosening operation for carrot cultivation in order to avoid the negative consequences associated with too low soil compactness, such as lower water supply, delayed ripeness of carrots and sub-optimal absorption potentials by the modified fibrous root system.

Additional studies relating optimal soil physical conditions which promote the absorption of ions and water to carbon utilization by carrot fibrous root systems are needed before the best management practice can be established for specific cultivars of carrots. 
Pietola, L.: Effect of soil compactness on the growth and quality of carrot

\section{References}

Abdalla, A. M., Hettiaratchi, D. R. P. \& Reece, A. R. 1969. The mechanics of root growth in granular media. Journal of Agricultural Engineering Research 14: 236248.

Agrawal, R. P. 1991. Water and nutrient management in sandy soils by compaction. Soil and Tillage Research: 19: 121-139.

Aguirrezabal, L. A. N., Deleens, E. \& Tardieu, F. 1994. Root elongation rate is accounted for by intercepted photosynthetic photon flux density and source-sink relations in field and laboratory-grown sunflower. Plant, Cell and Environment 17: 443-450.

Agung, I. G. A. M. Sri \& Blair, G. J. 1989. Effects of soil bulk density and water regime on carrot yield harvested at different growth stages. Journal of Horticultural Science $64: 17-25$.

Aiken, R. M. 1992. Functional relations of root distributions with the flux and uptake of water and nitrate. PhD thesis. East Lansing, Michigan State University. USA. $159 \mathrm{p}$.

Akker, J. J. H. van den, Arb, W. B. M., Koolen, A. J. \& Stuiver, H. J. 1994. Comparison of stresses, compactions and increase of penetration resistances caused by a low ground pressure tyre and normal tyre. Soil and Tillage Research 29: 125-134.

Akram, M. \& Kemper, W. D. 1979. Infiltration of soils as affected by the pressure and water content at the time of compaction. Soil Science Society of America Journal 43: 1080-1086.

Allison, L. E. 1969. Organic carbon. Agronomy 9: 13671378.

Anderson, G. Pidgeon, J. D., Spencer, H. B. \& Parks, R. 1980. A new hand-held recording penetrometer for soil studies. Journal of Soil Science 31: 279-296.

Ankeny, M. D., Kaspar, T. C. \& Horton, R. 1990. Characterization of tillage and traffic effects on unconfined infiltration measurements. Soil Science Society of America Journal 54: 837-840.

Asady, G. H., Smucker, A. J. M. \& Adams, M. W. 1985. Seedling test for the quantitative measurement of root tolerance to compacted soil. Crop Science 25: 802-806. Atwell, B. J. 1990a. The effect of soil compaction on wheat during early tillering. II Concentration of cell constituents. New Phytology 115: 37-41.

$-1990 \mathrm{~b}$. The effect of soil compaction on wheat during early tillering. III Fate of carbon transported to the roots. New Phytology 115: 43-49.

Aubert, S., Bonnet, A. \& Szot, B. 1979. Mise au point d'indices rhéologigues de texture en relations avec quelques caractères biochimiques chez la carotte ( $D a u$ cus carota L.). Annales de Technologie et Agriculture 28: 349-422.

Aura, E. 1975. Effects of soil moisture on the germination and emergence of sugar beet (Beta vulgaris L.). Journal of the Scientific Agricultural Society of Finland 47: 169.

- 1983. Soil compaction by tractor in spring and its effect on soil porosity. Journal of Agricultural Science in Finland 55: 91-107.
- 1985. Avomaan vihannesten veden ja typen tarve. Summary: Nitrogen and water reguiments for carrot, beetroot, onion and cabbage. Maatalouden tutkimuskeskus. Tiedote 7/85. $61 \mathrm{p}$.

Ayers, P. D. \& Perumpral, J. V. 1982. Moisture and density effect on cone index. Transactions of the American Society of Agricultural Engineers 25: 1169-1172.

Banga, O. 1963. Breeding for quality in some vegetables. Genetica Agraria 16: 27-37

- \& Bruyn, J. W. de 1964. Carotenogenesis in carrot roots. Netherlands Journal of Agricultural Science 12: 204-220.

-, Bruyn, J. W. de \& Smeets, L. 1955. Selection of carrots for carotene content. II Sub-normal content at low temperature. Euphytica 4: 183-189.

Barber, S. A. \& Silberbush, M. 1984. Plant root morphology and nutrient uptake. In: Barber, S. A. \& Boulen, D. R. (eds.). Roots, nutrient and water influx, and plant growth. Madison, American Society of Agronomy, Special Publication 49: 65-87.

Barley, K. P., Farrell, D. A. \& Greacen, E. L. 1965. The influence of soil strength on the penetration of a loam by plant roots. Australian Journal of Soil Research 3: 6979 .

Barnes, W. C. 1936. Effects of some environmental factors on growth and color of carrots. Cornell University Agricultural Experimental Station Memoir 186: 1-36.

Barnhill, R. E. \& Riesenfeld, F. 1974. Computer Aided Geometric Design. New York, Academic Press. 326 p.

Bengough, A. G. \& Mullins, C. E. 1990. Mechanical impedance to root growth - A review of experimental techniques and root growth responses. Journal of Soil Science 41: 341-358.

- \& Young, I. M. 1993. Root elongation of seedling peas through layered soil of different penetration resistances. Plant and Soil 149: 129-139.

Benjamin, L. R. \& Wren, M. J. 1978. Root development and source-sink relations in carrot, Daucus carota L. Journal of Experimental Botany 29: 425-433.

- \& Wren, M. J. 1980. Root development and sourcesink relations in carrot, Daucus carota L. Journal of Experimental Botany 31: 1139-1146.

Blake, G. R. 1965. Particle density. Agronomy 9: 371373.

-, Nelson, W. W. \& Allmaras, R. R. 1976. Persistence of subsoil compaction in a Mollisol. Soil Science Society of America Journal 40: 943-948.

Bland, W. L. 1989. Estimating root length density by the core break method. Soil Science Society of America Journal 53: 1595-1597.

Bleasdale, J. K. \& Thompson, R. 1963. An objective method of recording and comparing the shapes of carrot roots. Journal of Horticultural Science 38: 232-241.

Boone, F. R., Bouma, J. \& Smet, A. H. de. 1978. A case study on the effect of soil compaction and potato growth in a loamy sand soil. I Physical measurements and rooting patterns. Netherlands Journal of Agricultural Science 26: 405-420.

Bouyoucos, G. J. 1954. New type electrode for plaster 
Vol. 4: 139-237.

of paris moisture blocks. Soil Science 78: 339-342.

Bradley, G. \& Smittle, D. 1965. Carrot quality as affected by variety, planting and harvest dates. Proceedings of American Society for Horticultural Science 86: 397405.

Carter, M. R. 1988. Penetration resistance to characterize the depth and persistence of soil loosening in tillage studies. Canadian Journal of Soil Science 68: 657-668. Clarkson, D. T. \& Hanson, J. B. 1980. The mineral nutrition of higher plants. Annual Reviews of Plant Physiology 31: 239-298.

CoPlot Programme for Scientific Graphs. 1990. Berkeley, CoHort Software. 228 p.

Dexter, A. R. 1988. Strength of soil aggregates and of aggregate beds. Catena Supplement 11: 35-52.

- \& Hewitt, J.S. 1978. The deflection of plant roots. Journal of Agricultural Engineering Research 23: 17-22.

Domzal, H. \& Hodara, J. 1992. Agrophysical effects of different soils compaction. Proceedings of International Conference of Soil Compaction and Management, Tallinn, Estonia. p. 124-128.

-, Hodara, J. \& Skrynicki, J. 1992. Deformation depth of soil compacted by multiple passes of wheels. Proceedings of International Conference of Soil Compaction and Management, Tallinn, Estonia. p. 31-35.

Double-sonde Gammametrique L.P.C. - I.N.R.A. 1985. Montfavet, Centre de Recherches Agronomique d'Avignon. 13 p.

Dowker, B. D., Fennell, J. F. M. \& Jackson, J. C. 1974. Variation studies in carrots as an aid to breeding. II Effects of sites, years and densities on some quality characters. Journal of Horticultural Science 49: 311-321.

Dragland, S. 1978. Nitrogen- og vassbehov hos gulrot. Summary: Nitrogen and water requirements for carrots. Forskning og Försøk i Landbruket 29: 139-159.

Eavis, B.W. 1972. Soil physical conditions affecting seedling root growth. I Mechanical impedance, aeration, and moisture availability as influenced by bulk density and moisture levels in a sandy loam soil. Plant and Soil 36 : 613-622.

Eissenstat, D. M. 1992. Costs and benefits of constructing roots of small diameter. Journal of Plant Nutrition 15: 763-782.

- \& Caldwell, M. M. 1988a. Competitive ability is linked to rates of water extraction: a field study of two arid land tussock grasses. Oecologia 75: 1-7.

- \& Caldwell, M. M. 1988b. Seasonal timing of root growth in favorable microsites. Ecology 69: 870-873.

Elonen, P. 1971. Particle-size analysis of soil. Acta Agralia Fennica 122: 1-122.

-, Nieminen, L. \& Kara, O. 1967. Sprinkler irrigation on clay soils in southern Finland I. Sprinkler irrigation, its technique and effect on soil moisture. Journal of the Scientific Agricultural Society of Finland 39: 67-77.

Erickson, A. E. 1982. Tillage effects on soil aeration. In: Doren, D. M. van (ed.). Predicting Tillage Effects on Soil Physical Properties and Processes. Madison, American Society of Agronomy, Special Publication 44: 91-105.

Eriksson, J. 1976. Influence of extremely heavy traffic on clay soil. Grundförbättring 27: 33-51.

Evers, A.-M. 1988. Effects of different ferilization practices on the growth, yield and dry matter content of car- rot. Journal of Agricultural Science in Finland 60: 135152.

- 1989a. Effects of different fertilization practices on the carotene of carrot. Journal of Agricultural Science in Finland 61: 7-14.

- 1989b. Effects of different fertilization practices on the glucose, fructose, sucrose, taste and texture of carrot. Journal of Agricultural Science in Finland 61: 113-122. - 1994. The influence of fertilization and environment on some nutritionally important quality criteria in vegetables - a review of research in the Nordic countries. Agricultural Science in Finland 3: 177-188.

Ewing, R. P. \& Kaspar, T. C. 1993. An accurate method for measuring lengths of washed roots. Agronomy Abstracts 1993: 315.

Farrell, D. A. \& Greacen, E. L. 1966. Resistance to penetration of fine probes in compressible soil. Australian Journal of Soil Research 4:1-17.

Fiscus, E. L. \& Markhart, A. H., III 1979. Relationships between root system water transport properties and plant size in Phaseolus. Plant Physiology 64: 770-773.

Foth, H. D. 1990. Fundamentals of Soil Science. 8th edition. New York, John Wiley and Sons. 360 p.

Frede, H. G. 1985. The importance of pore volume and pore geometry to soil aeration. In: Monnier, G. \& Goss, M. J. (eds.). Soil Compaction and Regeneration. Boston, Comission of European Communities. p. 25-29.

Fritz, D. \& Habben, J. 1974. Determination of ripeness of carrots. Acta Horticulturae 52: 113-238.

- \& Weichmann, J. 1979. Influence of harvesting date of carrots on quality and quality preservation. Acta Horticulturae 93: 91-97.

Gerard, C. J., Sexton, P. \& Shaw, G. 1982. Physical factors influencing soil strength and root growth. Agronomy Journal 74: 875-881.

Gill, W. R. \& Bolt, G. H. 1955. Pfeffer's studies of the root growth pressures exerted by plants. Agronomy Journal 47: 166-168.

Glinski, J. \& Stepniewski, W. 1985. Soil Aeration and its Role for Plants. Boca Raton, CRC Press. 173 p.

Gormley, T. R., Oriordain, F. \& Prendville, M. D. 1971. Some aspects of the quality of carrots on different soil types. Journal of Food Technology 6: 393-402.

Grath, T. \& Hákansson, I. 1992. Effects of soil compaction on development and nutrient uptake of peas. Swedish Journal of Agricultural Research 22: 13-17.

Gupta, S. C. \& Larsson, W. E. 1985. Modeling soil mechanical behaviour durig tillage. In: Unger, P. W \& Doren, D. M. van (eds.). Predicting Tillage Effects on Soil Physical Properties and Prosesses. Madison, American Society of Agronomy, Special Publication 44: 151-178.

Harris, G. A. \& Campbell, G. S. 1991. Automated quantification of roots using a simple image analyzer. Agronomy Journal 81: 935-938.

Hartge, K. H. 1992. Compaction or homogenization. Proceedings of International Conference of Soil Compaction and Management, Tallinn, Estonia. p. 63-74.

Heinonen, M., Ollilainen, V., Linkola, E., Varo, P. \& Koivistoinen, P. 1988. Carotenoids and retinoids in Finnish foods: Ready-to-eat foods. Journal of Food Composition and Analysis 1: 221-230.

Heinonen, R. 1960. A soil core sampler with provision 


\section{AGRICULTURAL SCIENCE IN FINLAND}

\section{Pietola, L.: Effect of soil compactness on the growth and quality of carrot}

for cutting successive layers. Journal of Scientific Agricultural Society of Finland 32: 176-178.

Hillel, D. 1971. Soil and Water. Physical Principles and Processes. 1st edition. New York, Academic Press. 288 p. Hole, C. C. \& McKee, J. M. T. 1988. Changes in soluble carbohydrate levels and associated enzymes of fieldgrown carrots. Journal of Horticultural Science 63: 8793.

Horn, R. 1988. Compressibility of arable land. Catena Supplement 11: 53-71.

Huang, B. 1990. Growth, carbon partitioning, water and ion uptake by the root systems of Phaseolus seedlings subjected to soil mechanical impedance and water deficit stresses. M. S. Thesis. East Lansing. Michigan State University. USA. 75 p.

Hákansson, I. 1966. Experiments with different degrees of compaction in the topsoil and upper part of the subsoil. Grundförbättring 19: 281-332.

- 1990. A method for characterizing the state of compactness of the plough layer. Soil and Tillage Research 16: 105-120.

- 1992. The degree of compactness as a link between technical, physical and biological aspects of soil compaction. Proceedings of International Conference of Soil Compaction and Management, Tallinn, Estonia. p. 7578.

Inns, F. M. \& Kilgour, J. 1978. Agricultural Tyres. London, Dunlop Ltd. 70 p.

Instruction Manual for Use of Bush Recordings Soil Penetrometer. 1979. Midlothian, Irwine Limited. 35 p.

Itoh, S. \& Barber, S. A. 1983a. Phosphorus uptake by six plant species as related to root hairs. Agronomy Journal 75: 457-461.

- \& Barber, S. A. 1983b. A numerical solution of whole plant nutrient uptake for soil-root systems with root hairs. Plant and Soil 70: 403-413.

Jaakkola, A., Auramo, J. \& Simojoki, A. 1990. Effect of air composition on plant growth and nutrient uptake. 14th International Congress of Soil Science, Transactions 4: 62-65.

Johnson, J. F., Voorhees, W. B., Nelson, W. W. \& Randal, G. W. 1990. Soybean growth and yield as affected by surface and subsoil compaction. Agronomy Journal 82: 973-979.

Jokinen, R. 1977. Effects of added magnesium, potassium, lime and nitrogen on oats I. Yields. Journal of the Scientific Agricultural Society of Finland 49: 283-295.

Jones, C. A., Bland, W. L., Ritchie, J.T. \& Williams, J. R. 1991. Simulation of root growth. In: Hanks, J. \& Ritchie, J. T. (eds.). Modeling Plant and Soil Systems. Madison, American Society of Agronomy, Agronomy 31: 92-120. Jones, H. A., Tomos, A. D., Leigh, R. A. \& Jones, G. W. 1983. Water-relation parameters of epidermal and cortical cells in the primary root of Triticum aestivum L. Planta 158: 230-236.

Jorge, J. A., Mansell, R. S., Rhoads, F. M, Bloom. S. A. \& Hammond, L. C. 1992. Compaction of a fallow sandy loam soil by tractor tires. Soil Science 92: 322330 .

Juusela, T. \& Wäre, M. 1956. Suomen peltojen kuivatustila. Draining condition of the cultivated fields in Finland. Soil and Hydrotechnics Research 8: 1-89.
Kemper, W. D., Stewart, B. A. \& Porter, L. K. 1971. Effect of compaction on soil nutrient status. In: Barnes, K. K. et al. (eds.). Compaction of Agricultural Soils. American Society of Agricultural Engineers Monographe p. 178-189.

Kesik, T. 1990. Influence of loess soil compaction on the crop and some morphological and physical features of carrot roots. Zeszyty Problemowe Postepow Nauk Rolniczych 385: 81-96.

Kokko, E. G., Volkmar, K. M., Gowen, B. E. \& Entz, T. 1993. Determination of total root surface area in soil core samples by image analysis. Soil and Tillage Research 26: 33-43.

Kooistra, M. J., Schoonderbeek, D., Boone, F. R., Veen, B. W. \& Noordwijk, M. van 1992. Root-soil contact of maize, as measured by a thin-section technique. II Effects of soil compaction. Plant and Soil 139: 119129.

Kurki, M., Lakanen, E. Mäkitie, O. \& Sillanpää, M. 1965. Viljavuusanalyysien ilmoitustapa ja tulkinta. Summary: Interpretation of soil testing results. Annales Agriculturae Fenniae 4: 145-153.

Lehtinen, S. 1984. Avomaavihannesten lannoitus- ja kastelukokeet 1978-1983. (Experiments of fertilization and irrigation for field vegetables, in Finnish). Maatalouden tutkimuskeskus. Tiedote 21/84. 62 p.

Li, B.W. \& Schuhmann, P. J. 1981. Gaschromatographic analysis of sugars in granola cereals. Journal of Food Science 46: 425-427.

Lipiec, J, Hákansson, I. Tarkiewicz, S. \& Kossowski, J. 1991. Soil physical properties and growth of spring barley as related to the degree of compactness of two soils. Soil and Tillage Research 19: 307-317.

-, Kania, W. \& Tarkiewicz, S. 1990. Effect of wheeling on physical characteristics of soils and rooting of some cereals. Zeszyty Problemowe Postepow Nauk Rolniczych 385: 97-105.

-, Kossowski, J. \& Tarkiewicz, S. 1992. Spring barley yield and root growth in response to the degree of compactness of soil and weather conditions. Proceedings of International Conference of Soil Compaction and Management, Tallinn, Estonia. p. 86-89.

-, Kubota, T. Iwama, H. \& Hirose, J. 1988. Measurement of plant water use under controlled soil moisture conditions by the negative pressure water circulation technique. Soil Science and Plant Nutrition 34: 417-428. - \& Tarkiewicz, S. 1984 . The effect of soil compaction on the coefficient of hydraulic conductivity. Polish Journal of Soil Science 17: 9-14.

Logsdon, S. D. \& Allmaras, R. R. 1991. Maize and soybean root clustering as indicated by root mapping. Plant and Soil 131: 169-176.

McCully, M. E. \& Canny, M. J. 1989. Pathways and processes of water and nutrient movement in roots. In: Loughman, B. C. et al. Kolek, J. (eds.). Structural and Functional Aspects of Transport in Roots. London, Academic Publishers. p. 3-14.

McKyes, E., Negi, S., Douglas, E., Taylor, F. \& Raghavan, V. 1979. The effects of machinery traffic and tillage operation on the physical properties of a clay and on yield of silage corn. Journal of Agricultural Engineering Research 24: 143-148. 
Vol. 4: 139-237.

Mahrer, Y. \& Avissar, R. 1985. A numerical study of the effects of soil surface shape upon the soil temperature and moisture regimes. Soil Science 139: 483-490.

Malicki, J., Bieganowski, A. \& Dabek-Szreniawska, M. 1991. Mathematical modeling of biological activity in differently compacted soils. Soil and Tillage Research 19: 357-362.

Martino, D. L. \& Shaykewich, C. F. 1994. Root penetration profiles of wheat and barley as affected by soil penetration resistance in field conditions. Canadian Journal of Soil Science 74: 193-200.

Massle, J. \& Passioura, J. B. 1987. The effect of soil strength on the growth of young wheat plants. Australian Journal of Plant Physiology 4: 643-656.

Materechera, S. A., Dexter, A. R. \& Alston, A. M. 1991. Penetration of a very strong soils by seedling roots of different plant species. Plant and Soil 135: 31-41.

-, Alston, A. M., Kirby, J. M. \& Dexter, A. R. 1993. Field evaluation of laboratory techniques for predicting the ability of roots to penetrate strong soil and the influence of roots on water sorptivity. Plant and Soil 149: 149-158. Medvedev, V. W. 1992. Compaction of chernozems and plant production. Proceedings of International Conference of Soil Compaction and Management, Tallinn, Estonia. p. 90-94.

Mehta, B. K., Shiozawa, S. \& Nakano, M. 1994. Hydraulic properties of sandy soil at low water contents. Soil Science 157: 208-214.

Miedzobrodzka, A., Sikora, E., Cieslik, E. \& Leszczynska, T. 1993. Nitrate and nitrite levels in carrot roots. Die Nahrung 37: 41-45.

Millette, J. A. 1983. Effect of water table depths on the growth of carrots and onions on an organic soil in vitro. Canadian Journal of Plant Science 63: 739-746.

-, Vigier, B. \& Hogue, E. J. 1981. Seedbed preparation for carrot production on organic soil. Journal of the American Society for Horticultural Science 106: 491-493.

Misra, R. K., Dexter, A. R. \& Alston, A. M. 1986. Maximum axial and radial growth pressures of plant roots. Plant and Soil 95: 315-326.

Moltz, F. J. 1981. Models of water transport in the soilplant system: a review. Water Resources Research 17: 1245-1260.

Monroe, G. E. \& Taylor, J. H. 1989. Traffic lanes for controlled traffic cropping systems. Journal of Agricultural Engineering Research 44: 23-31.

Newman, E. I. 1966. A method of estimating the total length of root in a sample. Journal of Applied Ecology 3: 139-145.

Nilsson, T. 1984. Towards an understanding of the environmental and genetic influences on vegetable quality. Retrospects and prospects. Acta Horticulturae 163: 199212.

Noordwijk, M. van \& Brouwer, G. 1991. Review of quantitative root length data in agriculture. In: McMichael, B. L. \& Persson, H. (eds.). Plant Roots and their Environment. New York, Elsevier. p. 515-527.

- \& Schoonderbeck, D. \& Kooistra, M. J. 1993. Rootsoil contact of field-grown winter wheat. Geoderma 56 : $277-286$.

- \& Willigen, P. de 1991. Root functions in agricultural systems. In: McMichael, B. L. \& Persson, H. (eds.). Plant
Roots and their Environment. New York, Elsevier. p. 381395.

Nye, P. H. \& Tinker, P. B. 1977. Solute Movement in Soil-root System. 1st edition. Oxford, Blackwell Scientific Publications. $342 \mathrm{p}$.

Olymbios, C. M. \& Schwabe, W. W. 1977. Effects of aeration and soil compaction on growth of carrot. Journal of Horticultural Science 52: 489-500.

O'Sullivan, M. F. 1992. Unaxial compaction effects on soil physical properties in relation to soil type and cultivation. Soil and Tillage Research 24: 257-269.

Ouwerkerk, C. van \& Noordwijk, M. van 1991. Effect of traffic intensity on soil structure and root development in a field experiment on a sandy clay loam soil in the Netherlands. Proceedings of the 12th International Conference of the International Soil Tillage Research Organization, Ibadan, Nigeria. p. 253-262.

Pan, W. L. \& Bolton, R. P. 1991. Root quantification by edge discrimination using a desktop scanner. Agronomy Journal 83: 1047-1052.

Pfeffer, W. 1893. Druck und Arbeitsleistung durch Wachsende Pflanzen. Abhandlungen der Königlich Săchsischen Gesellschaft der Wissenschaften 33: 235-474.

Phan, C. T. \& Hsu, H. 1973. Physical and chemical changes occuring in the carrot root during growth. Canadian Journal of Plant Science 53: 629-634.

Pietola, L. 1991. Effect of clay soil strength and structure on root penetration and crop yield. Annales Agriculturae Fenniae 30: 345-358.

Platenius, H. 1934. Chemical changes in carrots during growth. Plant Physiology 9: 671-680.

Pohjanheimo, O. \& Heinonen, R. 1960. The effect of irrigation on root development, water use, nitrogen uptake and yield characteristics of several barley varietes. Acta Agralia Fenniae 95: 1-20.

Prathapar, S. A., Meyer, W. S. \& Cook, F. J. 1989. Effect of cultivation on the relationship between root length density and unsaturated hydraulic conductivity in a moderately swelling clay soil. Australian Journal of Soil Research 27: 645-650.

Pritchard, J., Barlow, P. W., Adams, J. S. \& Tomos, A. D. 1990a. Biophysics of the inhibition of the growth of maize roots by lowered temperature. Plant Physiology 93: 222-230.

- , Wyn Jones, R. D. \& Tomos, A. D. 1990b. Measurement of yield treshold and cell wall extensibility of intact wheat roots under different ionic, osmotic and temperature treatments. Journal of Experimental Botany 41: 669675.

Ranta, E., Rita H. \& Kouki, J. 1991. Biometria. Tilastotiedettä ekologeille. (Biometry. Statistics for Ecologists, in Finnish). 3rd. ed. Helsinki, Yliopistopaino. 569 p.

Reicosky, D. C., Voorhees, W. B. \& Radke, J. K. 1981. Unsaturated water flow through a simulated wheel track. Soil Science Society of America Journal 45: 3-8.

Richards, B. G. \& Greacen, E. L. 1986. Mechanical stresses on an expanding cylindrical root analogue-granular media. Australian Journal of Soil Research 24:393404.

Riley H. 1988. Cereal yields and soil physical properties in relation to the degree of compactness of some Norwegian soils. Proceedings of the 11th International Confer- 
Pietola, L.: Effect of soil compactness on the growth and quality of carrot

ence of the International Soil Tillage Research Organization, Edinburgh, Scotland. p. 109-114.

Rosenfeld, H. J., Martens, M. \& Lea, P. 1984. Variations in sensory and physical characteristics in carrots (Daucus carota L.). Acta Horticulturae 163: 63-70.

Schumacher, T. E. \& Smucker, A. J. M. 1981. Mechanical impedance effects on oxygen uptake and porosity of dry-bean roots. Agronomy Journal 73: 51-55.

- 1984. Effect of localized anoxia on Phaseolus vulgaris L. root growth. Journal of Experimental Botany 35: 10391047.

- 1987. Ion uptake and respiration of dry bean roots subjected to localized anoxia. Plant and Soil 99: 411-422.

Schuurman, J. J. \& Schäffner, B. E. 1974. De wortelontwikkeling van enige tuinbougewassen op zandgrond. Instituut voor Bodemvruchtbaarheid, Rapport 11/74.62 p. Simojoki, A., Jaakkola, A. \& Alakukku, L. 1991. Effect of compaction on soil air in a pot experiment and in the field. Soil and Tillage Research 19: 175-186.

Simon, P. W., Peterson, C. E. \& Lindsay, R. C. 1982. Genotype, soil and climate effects on sensory and objective components of carrot flavor. Journal of the American Society for Horticultural Science 107: 644-648.

Sippola, J. 1982. A comparison between a dry combustion method and rapid wet combustion method for determining soil organic carbon. Annales Agriculturae Fenniae 21: 146-148.

- \& Erviö, R. 1977. Determination of boron in soils and plants by the azomethine- $\mathrm{H}$ method. Finnish Chemical Letters 1977: 138-140.

Smucker, A. J. M. 1990. Quantification of root dynamics in agroecological systems. In: Goel, V. S. \& Normal, J. M. (eds.). Instrumentation for Studying Vegetation Canopies for Remote Sensing in Optical and Thermal Infrared Regions. Remote Sensing Reviews 5: 237-248.

- 1993. Soil environmental modifications of root dynamics and measurement. Annual Reviews of Phytopathology 31: 191-216.

- \& Erickson, A. E. 1989. Tillage and compactive modifications of gaseous flow and soil aeration. In: Larson, W. E. et al. (eds.). Mechanics and Related Processes in Structured Agricultural Soils. Boston, Kluwer Academic Publishers. p. 205-221.

-, Ferguson, J. C., Debruyn, W. P., Belford, R. L. \& Ritchie, J. T. 1987. Image analysis of video recorded plant root systems. In: Taylor, H. M. (ed.). Minirhizotron Observation Tubes: Methods and Applications for Measuring Rhizosphere Dynamics. Madison, American Society of Agronomy, Special Publication 50: 67-80.

-, Nunez-Barios, A. \& Ritchie, J. T. 1991. Root dynamics in drying soil environment. Belowground Ecology, Spring/91: 4-5.

- McBurney, S. L. \& Srivastava, A. K. 1982. Quantitative separation of roots from compacted soil profiles by the hydropneumatic elutration system. Agronomy Journal 74: 500-503.

Soane, B. D. 1992. Crop yield responses to zero- and reduced ground pressure- traffic systems in relation to weather conditions in Scotland. Proceedings of International Conference of Soil Compaction and Management, Tallinn, Estonia. p. 54-57.

-, Blackwell, P. S., Dickson, J. W. \& Painter, D. J. 1980.
Compaction by agricultural vehicles: A review I. Soil and wheel characteristics. Soil and Tillage Research 1:207237.

Soil Testing Laboratory of Finland 1990. Viljavuustutkimuksen tulkinta peltoviljelyssä. (Soil Analysis and Application, in Finnish). Helsinki. 70 p.

Steel, R. G. D. \& Torrie, J. H. 1981. Principles and Procedures of Statistics - A Biometrical Approach. 2nd ed. Singapore, McGraw-Hill International Book Company. $633 \mathrm{p}$.

Stengel, P., Gabilly, Y., Bartuzzi, P. \& Gaudu, J. C. \& Brifault, A. 1986. La double sonde gamma LPC-INRA. Définition, expérimentation et utilisation en agronomie. Bulletin de Liaison des Laboratoires des Ponts et Chaussées 141: 109-120.

Strandberg, J. O. \& White, J. M. 1979. Effect of soil compaction on carrot roots. Journal of the American Society for Horticultural Science 104: 344-349.

Strzalka, J. 1990. Effects of zone tillage and compaction on growth of carrots and onions in organic soils. M. S. Thesis. East Lansing, Michigan State University. USA. $122 \mathrm{p}$.

Taksdal, G. 1984. Effects of tractor wheelings on carrot quality. Acta Horticulturae 163: 255-260.

Tardieu, F. 1994. Growth and functioning of roots and of root systems to soil compaction. Towards a system with multiple signalling? Soil and Tillage Research 30: 217-243.

Taylor, H. M., Upchurch, D. R. \& McMichael, B. L. 1990. Applications and limitations of rhizotrons and minirhizotrons for root studies. Plant and Soil 129: 29-35.

Thompson, R. 1969. Some factors affecting carrot root shape and size. Euphytica 18: 277-285.

Turner, N. C., Schulze, E.-D. \& Gollan, T. 1985. The responses of stomata and leaf gas exchange to vapour pressure deficits and soil water content. II In the mesophytic herbaceous species Helianthus annuus. Oecologia 65 : 348-355.

Veen, B. W., Noordwijk, M. van, Willigen, P. de, Boone, F. R. \& Kooistra, M. J. 1992. Root-soil contact of maize, as measured by a thin-section technique. III Effects on shoot growth, nitrate, and water uptake efficiency. Plant and Soil 139: 131-138.

Voorhees, W. B., Carlson, V. A. \& Hallauer, E. A. 1980. Root length measurement with a computer-controlled digital scanning microdensitometer. Agronomy Journal 72 : 847-851.

-, Farrell, D. A. \& Larson, W. E. 1975. Soil strength and aeration effects on root elongation. Soil Science Society of America Proceedings 39: 948-953.

-, Senst, C. G. \& Nelson, W. W. 1978. Compaction and soil structure modification by wheel traffic in the nothern corn belt. Soil Science Society of America Journal 42: 344-349.

-, Young, R. A. \& Lyles, L. 1979. Wheel traffic considerations in erosion research. Transactions of the American Society of Agricultural Engineers 22: 789-790.

Vuorinen, J. \& Mäkitie, O. 1955. The method of soil testing in use in Finland. Agrogeological Publication 63: 144.

Vuorinen, M. \& Takala, M. 1987. Porkkanan ja punajuurikkaan sadetus, typpilannoitus ja kalkitus poutivalla hiekkamaalla. (Irrigation, $\mathrm{N}$-fertilization and liming for 
Vol. 4: 139-237.

carrot and beetroot, in Finnish). Maatalouden tutkimuskeskus. Tiedote 10/87. $30 \mathrm{p}$.

White, J. M. 1978. Soil preparation effects on compaction, carrot yield and root characteristics in organic soil. Journal of the American Society for Horticultural Science 103: 433-435.

- 1992. Carrot yield when grown under three soil water concentrations. HortScience 27: 105-106.

- \& Strandberg, J. O. 1979. Physical factors affecting carrot root growth: water saturation of soil. Journal of the American Society for Horticultural Science 104: 414-416. Whiteley, G. M., Utomo, W. H. \& Dexter, A. R. 1981. A comparison of penetrometer pressures and the pressures exerted by roots. Plant and Soil 61: 351-364.

Wiklert, P. 1960. Studier av rotutveckling hos några nyttovăxter med sărskild hănsyn till markstrukturen. Grundförbăttring 3: 113-148.

Wilde, S. A. \& Voigt, G. K. 1955. Analysis of Soils and
Plants for Foresters and Horticulturists. 1st edition. Ann Arbor, J. W. Edwards Publisher. 117 p.

Willat, S. T. 1986. Root growth of winter barley in a soil compacted by the passage of tractors. Soil and Tillage Research 7: 41-50.

Xu, J. G. \& Juma, N. G. 1994. Relations of shoot C, root $\mathrm{C}$ and root length with root-released $\mathrm{C}$ of two barley cultivars and the decomposition of root-released $\mathrm{C}$ in soil. Canadian Journal of Soil Science 74: 17-22.

Zhang, J. \& Davies, W. J. 1989. Abscisic acid produced in dehydrating roots may enable the plant to measure the water status of the soil. Plant, Cell and Environment 12: 73-81.

Zoon, F. C. \& Tienderen, P. H. van 1990. A rapid quantitative measurement of root length and root branching by microcomputer image analysis. Plant and Soil 126 : 301-308. 
Pietola, L.: Effect of soil compactness on the growth and quality of carrot

\title{
SELOSTUS
}

\section{Maan tiiviyden vaikutus porkkanan kasvuun ja sadon laatuun}

\author{
Liisa Pietola \\ Maatalouden tutkimuskeskus, Kasvintuotannon tutkimuslaitos \\ Helsingin yliopisto, Soveltavan kemian ja mikrobiologian laitos (nykyinen työpaikka)
}

\begin{abstract}
Vuosina 1989-1991 perustettiin porkkanakoekenttiä Etelä-Suomessa hieta-, savi- ja multamaalle. Tutkimuksessa mitattiin kynnöksen kuohkeuttamisen ja tiivistämisen sekä sadetuksen vaikutuksia maan fysikaalisiin ominaisuuksiin ja kasvukuntoon. Tutkimuskasvina käytettiin porkkanaa (lajikkeena Nantes Duke), jonka varastojuureksen ulkoisen laadun tiedettiin reagoivan herkästi maan tiiviyteen. Keskeisenä tutkimuskohteena oli myös sadon sisäinen laatu ja sen suhde juuriston pinta-alaan maan tiiviyden muuttuessa.
\end{abstract}

Kynnöstä kuohkeutettiin kahdella eri tavalla: 1 . Perunamaan multauslaitteella muotoiltiin $2 \mathrm{~m}$ leveisiin koeruutuihin $45 \mathrm{~cm}$ välein 4 harjua. 2 . Kelajyrsimellä kuohkeutettiin $2 \mathrm{~m}$ leveitä penkkejä $20 \mathrm{~cm}$ syvyyteen, savimaalla $15 \mathrm{~cm}$ syvyyteen. Lisäksi kynnöstä tiivistettiin ajamalla traktorilla pyörä pyörän jälkeen kiinni joko kerran tai kolmesti. Traktorin taka-akselikuormitus oli 3 tonnia. Kuohkeutus- ja tiivistysajot tehtiin välittömästi ennen kylvöä maan ollessa kosteata. Viidentenä oli käsittelemätön koejäsen. Kaikissa maan mekaanisissa käsittelyissä käytettiin traktorissa 2 metrin raideväliä, jolloin vältyttiin ylimääräiseltä maan tallaamiselta. Sadetuskäsittelyssä hieta- ja savimaan kentät sadetettiin maan kuivuessa alle $50 \%$ :iin hyötykapasiteetista. Ruutuihin oli keväällä upotettu $60 \mathrm{~cm}$ korkeita ja $30 \mathrm{~cm}$ läpimittaisia PVC-lieriöitä. Sadonkorjuuaikana ne nostettiin maasta porkkanan varasto- ja sivujuurien yksityiskohtaisia analyysejä varten. Sivujuuriston pituus ja leveys eri maakerroksissa mitattiin kuva-analysointimenetelmällä.

Kenttämittausten mukaan viljelymaan tiivistäminen kylvömuokkauksen yhteydessä kevyellä traktorilla lisäsi karkean hiedan, runsasmultaisen saven ja multamaan kyntökerroksen tilavuuspainoa ja mekaanista vastusta. Kivennäismaalajit tiivistyivät vain ylimmässä $25 \mathrm{~cm}: n$ kerroksessa, mutta multamaalla tiivistysten vaikutukset ulottuivat kyntökerroksen alapuolelle. Traktorilla ajo lisäsi kyntökerroksen tilavuuspainoa $8 \%$ hiedalla, $10 \%$ multamaalla ja $13 \%$ savella. Sama tilavuuspainon suhteellinen muutos lisäsi mekaanista vastusta hietamaalla $100 \%$ enemmän kuin multamaalla, kun maiden kosteus oli $50 \%$ hyötykapasiteetista.

Tiivistetyt maat pidättivät vettä enemmän kuin kuohkeutetut (kapeat harjut tai jyrsitty penkki), kun vesipitoisuus laskettiin suhteessa maan tilavuuteen. Tämä johtui lähinnä pienten $(\leq 0,2 \mu \mathrm{m})$ huokosten lisääntymisestä maata tiivistettäessä. Koekenttämaiden kokonaishuokostilavuus ja erityisesti suurten huokosten osuus laskivat olennaisesti tiiviysasteen lisääntyessä. Kolmesti tiivistetyllä savimaalla suurten huokosten $(\geq 30 \mu \mathrm{m})$ osuus maan tilavuudesta painui alle $10 \%$ rajan. Tiivistysajot vaikuttivat selkeästi maan ilman koostumukseen savimaalla ja varsinkin multamaalla, jossa alin mitattu happipitoisuus oli $10 \%$. Myös varastojuureksen nopea kasvu laski maan ilman happipitoisuutta. Hietamaalla maan fysikaalisista ominaisuuksista mekaaninen vastus muodostui kasvua rajoittavaksi tekijäksi, kun kuivassa tiivistetyssä kyntökerroksessa vastus kohosi yli 2,5 MPa:n rajan penetrometrillä mitattuna.

Kaikilla tutkimusmaalajeilla kyntökerroksen tiiviysaste oli noin $93 \%$ kolmen tiivistysajon jälkeen. Maan tiiviysasteella tarkoitetaan maan tilavuuspainon suhdetta maksimaaliseen tilavuuspainoon. Vain savimaassa tämä tiiviys heikensi ratkaisevasti porkkanan kasvuedellytyksiä. Savimaassa kynnöksen äestys vakioraiteita käyttäen osoittautui parhaimmaksi muokkausmenetelmäksi, kun porkkanan eri kehitysvaiheet otetaan huomioon. Liiallinen kuohkeutus johti epätasaiseen ja viivästyneeseen taimettumiseen, ja sadon määrä laski sadettamattomissa kuohkeutetuissa harjuissa tai penkissä yhtä paljon kuin tiivistetyissä koeruuduissa. Hietamaalla kuivissa olosuhteissa kuohkeutus viivästytti taimien kehitystä ja tiivistys rajoitti porkkanan kasvua, mutta lopullisen sadon määrää mekaaniset käsittelyt säätelivät vähän. Multamaalla maan tiivistäminen edisti niin ikään taimien kehitystä, mutta vaikutti muuten vähän porkkanan kasvurytmiin ja lopulliseen satoon.

Viljelymaan mekaaniset käsittelyt ja sadetus vaikuttivat huomattavasti selvemmin porkkanan muotoon kuin sisäiseen laatuun. Maan tiivistäminen hei- 


\section{AGRICULTURAL SCIENCE IN FINLAND}

Vol. 4: 139-237.

kensi porkkanan pituuskasvua, lieriömäisyyttä ja lisäsi haljenneiden porkkanoiden määrää. Porkkanan kehitysvaihe, sääolosuhteet ja maalaji säätelivät porkkanan kemiallista laatua huomattavasti enemmän kuin maan tiiviysaste. Jopa tiiviillä savimaalla saavutettiin kasvukaudelle ominaiset porkkanan karoteeni- (10 mg 100 grammassa tuoretta porkkanaa) ja sokeripitoisuudet $(5 \%)$. Samanaikaisesti tiiviin savimaan porkkanat sisälsivät vähemmän mehua sekä enemmän kuiva-ainetta ja raakaa kuitua kuin kuohkean savimaan tai muiden maalajien porkkanat. Alin karoteenipitoisuus $(3,5 \mathrm{mg} / 100 \mathrm{~g})$ mitattiin multamaan jyrsitystä penkistä vuonna 1990, jolloin syyskesä oli poikkeuksellisen viileä. Tiivistäminen lisäsi karoteenipitoisuuden tasolle $5 \mathrm{mg} / 100 \mathrm{~g}$. Sadetus vaikutti porkkanan karoteenipitoisuuksiin eri tavoin eri vuosina, kun taas sokeripitoisuuteen sadetuksella ei ollut osuutta.

Vakaana pysynyt kemiallinen laatu eri käsittelyjen välillä samassa kasvuvaiheessa ja samana vuonna voidaan selittää porkkanan ohuiden juurenhaarojen avulla, joita yksi porkkana kasvatti noin $200 \mathrm{~m}$ tiivistetyssä ja 120 m kuohkeassa sadettamattomassa hietamaassa $0-50 \mathrm{~cm}: n$ syvyydessä. Tiivistetyssä multamaassa mitattiin vielä suurempia pituuksia. Suurin osa (80-90\%) tästä pituudesta koostui juurista, joiden halkaisija oli noin $0,15 \mathrm{~mm}$. Juuristo, joka muodostuu näin ohuista juurista, mahdollistaa porkkanan tehokkaan veden ja ravinteiden oton. Tiivistys ja sadetus lisäsivät juuriston kuiva-ainepainoa, kokonaispituutta tai pinta-alaa lähinnä vain $0-30$ $\mathrm{cm}: \mathrm{n}$ kerroksessa, jossa porkkanan juuristo pääosin sijaitsi. Tutkimus antaa viitteitä siitä, että porkkanan varastojuureksen karoteeni- ja sokeripitoisuuden lisääntyminen kasvukauden loppua kohti on varminta kohtalaisesti tiivistetyssä kyntökerroksessa, jossa vedenpidätyskapasiteetti ja juuriston pinta-ala oli suurempi kuin mekaanisesti kuohkeutetussa maassa.

Tutkimuksen tulokset mekaanisten käsittelyjen vaikutuksista maan fysikaalisiin ominaisuuksiin ja porkkanan ulkoiseen laatuun saavat tukea aikaisemmista tutkimuksista. Porkkanan sisäinen laatu, jota perimä ja kehitysvaihe hallitsevat, ei ollut yhtä selkeästi maan fysikaalisten kasvutekijöiden säädeltävissä kuin ulkoinen laatu. Uudet tulokset porkkanan sisäisestä laadusta sekä juuriston pituuden ja pinta-alan jakautumisesta maaprofiilissa korostavat, että porkkanan sivujuuriston koko on riittävä takaamaan tiiviydestä kärsineen varastojuureksen biokemiallisen kypsymisen. Tätä tukee se, että tiivistetyssä maassa porkkanan nopeasti kehittynyt lehtimassa pystyi hyödyntämään kasvukauden säteilyn. Tutkimuksen perusteella porkkanaa ei kannata kylvää hyvin kuohkealle kasvualustalle, sillä lievä tiiviys varmistaa porkkanan varastojuureksen nopean kehityksen ja hyvän sisäisen laadun Suomen lyhyenä kasvukautena. 


\section{AGRICULTURAL SCIENCE IN FINLAND}

Appendix 1

Arrangement of field plots on fine sand (1989-1991). Dates of mechanical treatments and irrigations.

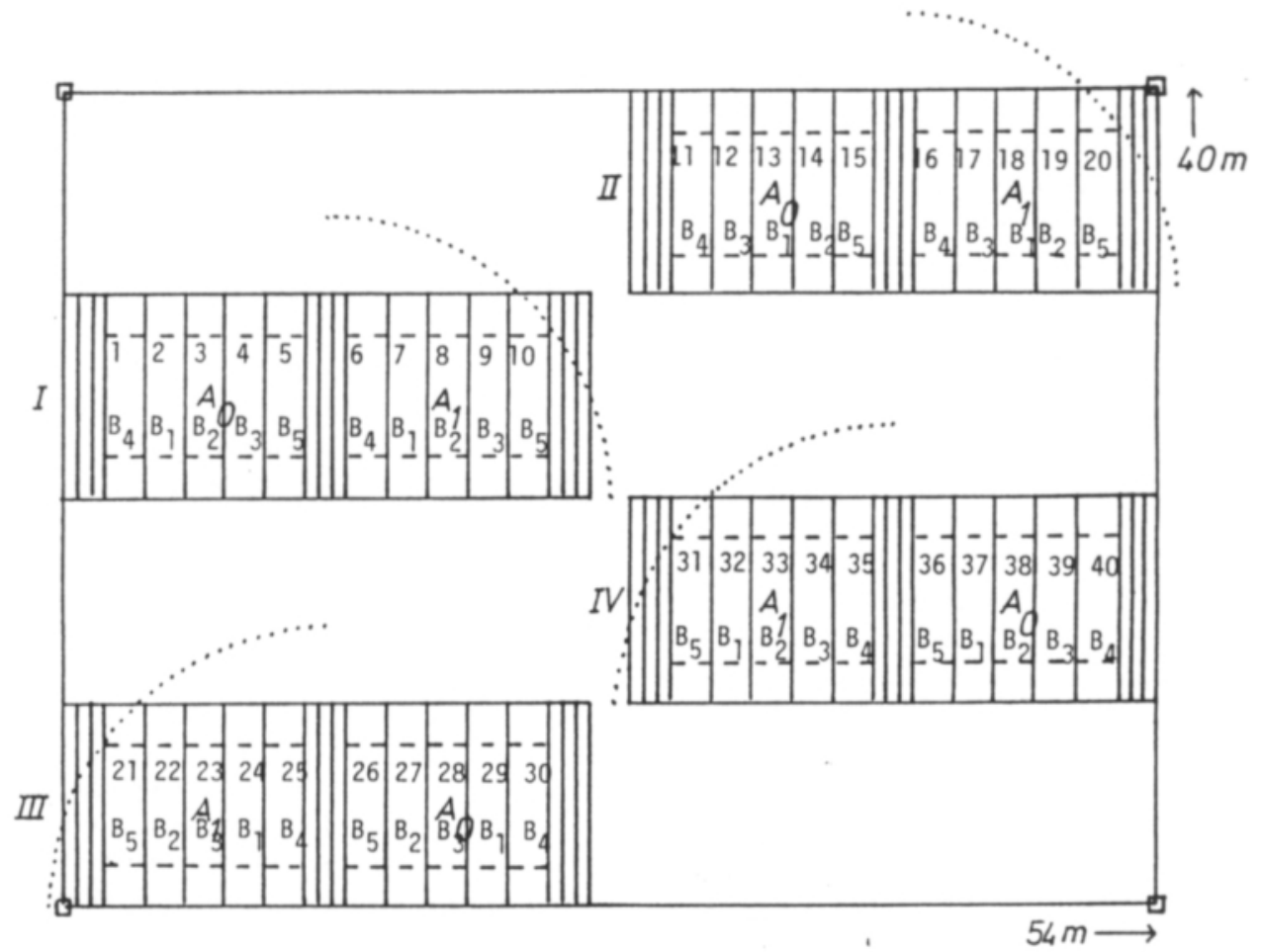

Main plots:

A. Sprinkler irrigation

$\mathrm{A}_{0}=0 \mathrm{~mm}$

$\mathrm{A}_{1}=2 \times 30 \mathrm{~mm}$

(dotted line indicates irrigated sector)
Subplots:

B. Mechanical treatments

\section{Loosening}

$\mathrm{B}_{1}=$ narrow ridges

$\mathrm{B}_{2}=$ rotary harrowing

$\mathrm{B}_{3}=$ no traffic (untreated)

Compaction

$\mathrm{B}_{4}=$ one pass of the tractor wheel

$\mathrm{B}_{5}=$ three passes of the tractor wheel

Dates of mechanical treatments (sowing date in parentheses)

26 April (27 April) 1989

18 April (20 April) 1990

24 April (25 April) 1991

Dates of irrigation (amount of water, $\mathrm{mm}$, in parentheses)

3 July 1989 (33)

13 June 1990 (35)

9 July 1989 (34)

27 June 1990 (35) 


\section{Appendix 2}

Arrangement of field plots on clay soil (1989). Dates of mechanical treatments and irrigations.

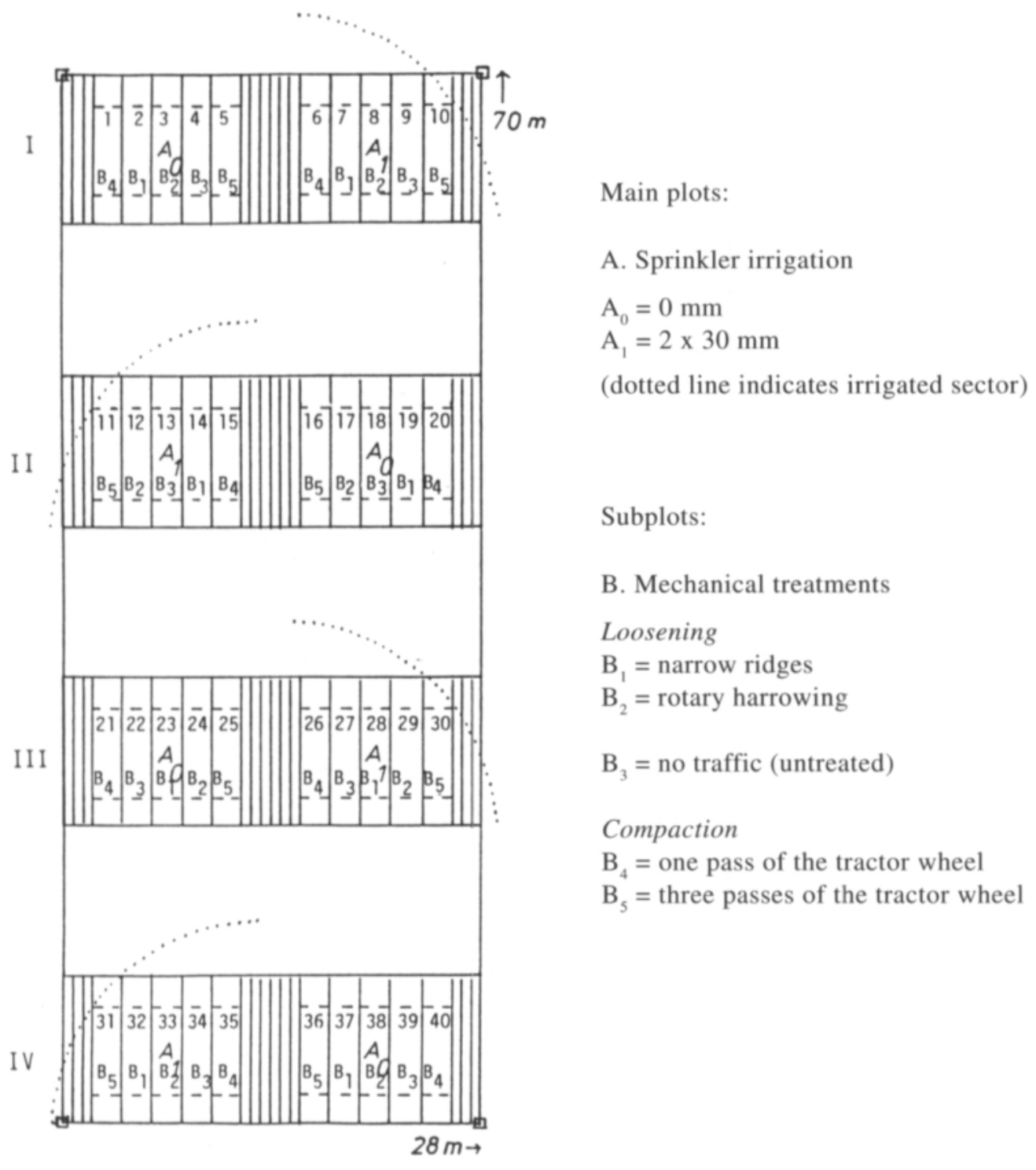

Dates of mechanical treatments (sowing date in parentheses)

11 May (12 May) 1989

Dates of irrigation (amount of water, $\mathrm{mm}$, in parentheses)

4 July 1989 (31)

9 July $1989(28)$ 


\section{Appendix 3}

Arrangement of field plots on mull soil (1990-1991). Dates of mechanical treatments.

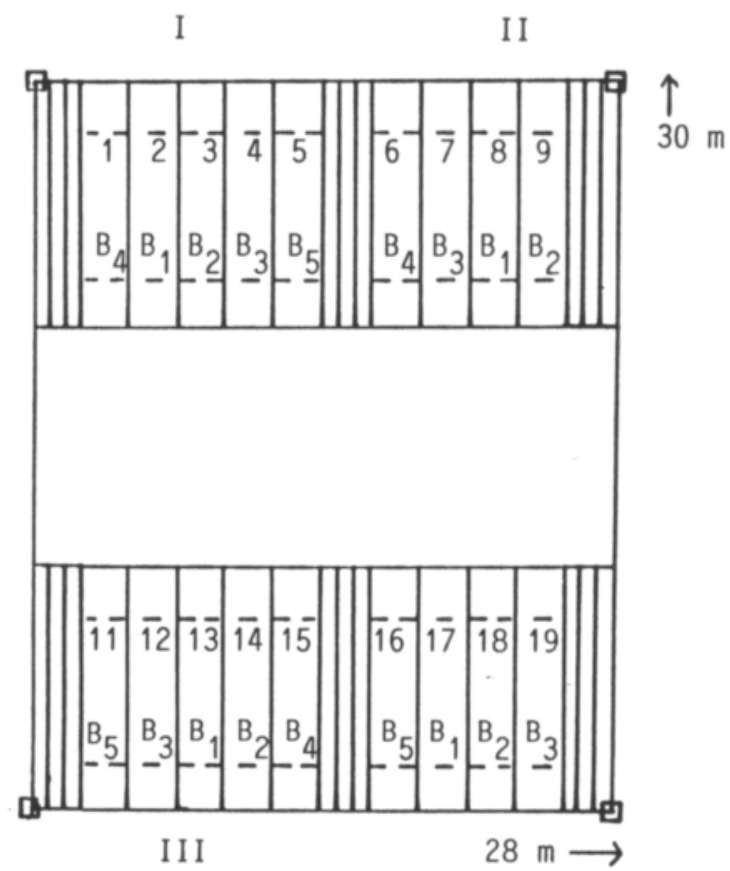

Plots (with no irrigation)

B. Mechanical treatments

\section{Loosening}

$\mathrm{B}_{1}=$ narrow ridges

$\mathrm{B}_{2}=$ rotary harrowing

$\mathrm{B}_{3}=$ no traffic (untreated)

\section{Compaction}

$\mathrm{B}_{4}=$ one pass of the tractor wheel

$\mathrm{B}_{5}=$ three passes of the tractor wheel

Dates of mechanical treatments (sowing date in parentheses)

18 April (21 April) 1990

26 April (30 April) 1991 
Sampling arrangement for field plots.

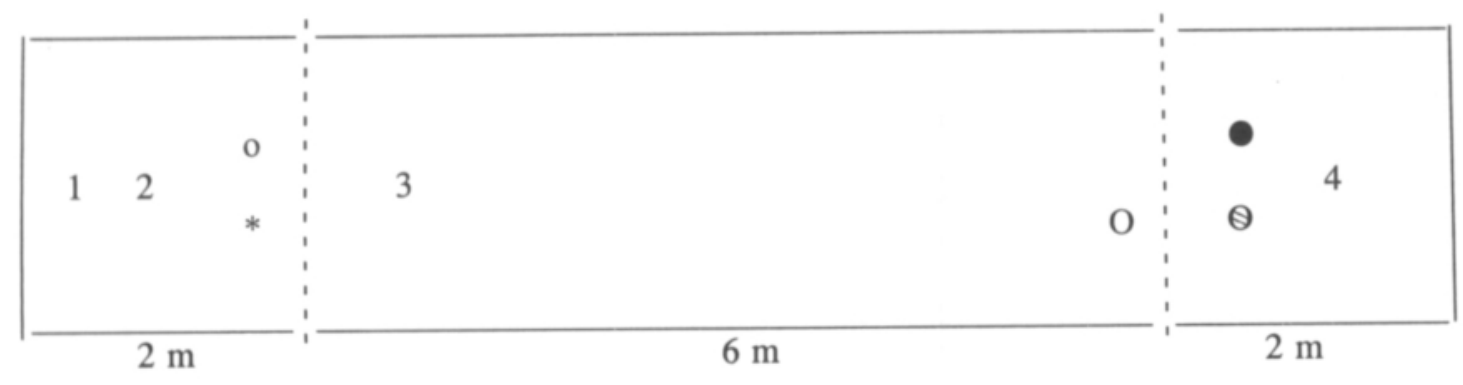

gypsum block (1989-991)

air sampling (1989-1990)

penetrometer resistance measurements (1989-1991)

final tap root yield area between broken lines (1989-1990)

O PVC cylinders $($ black $=1989$, shaded $=1990$, white $=1991)$

1) first plant sampling

(fine sand 1989-1991: 80, 89 and 90 DAS, respectively)

(clay 1989: 81 DAS)

(mull 1990-1991: 95 and 90 DAS, respectively)

$200-\mathrm{cm}^{3}$ core sampling for soil porosity and dry bulk density (1989-1990)

$2^{1)} \quad$ second plant sampling

(fine sand 1989-1991: 109, 123 and 117 DAS, respectively)

(clay 1989: 108 DAS)

(mull 1990-1991: 129 and 121 DAS, respectively)

$50-\mathrm{cm}^{3}$ core sampling for soil moisture and dry bulk density (1990-1991)

3 third plant sampling

(fine sand 1989-1991: 137, 158 and 145 DAS, respectively)

(clay 1989: 140 DAS)

(mull 1990-1991): 165 and 146 DAS, respectively)

$4 \quad 50-\mathrm{cm}^{3}$ core sampling for soil moisture and dry bulk density (1990-1991)

gamma ray transmission for soil dry bulk density (1990)

1) plant sampling at both ends of the plot (1989-1990) 


\section{Appendix 5}

Dry weight distribution of carrot fibrous roots in rotary harrowed $\left(\mathrm{B}_{2}\right)$ and three times compacted $\left(\mathrm{B}_{5}\right)$ clay soil in relation to soil volume (above) and tap root dry weight (below).

Soil depth, cm

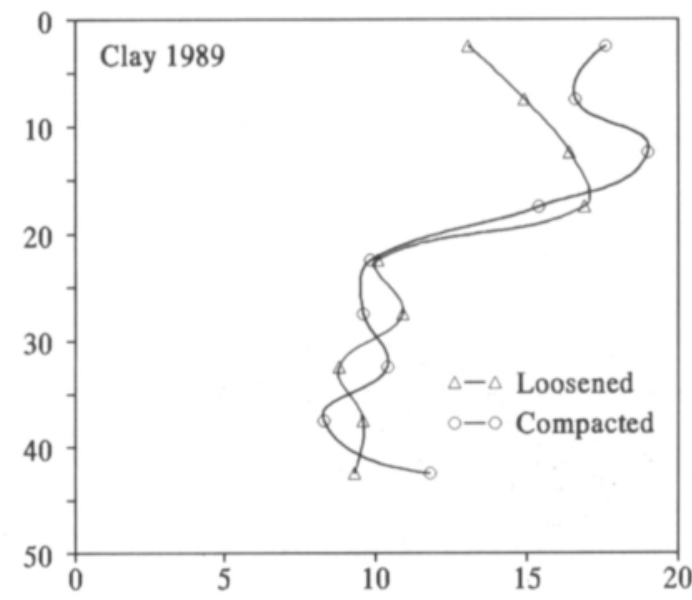

Fibrous root dry weight, $\mu \mathrm{g} \mathrm{cm}^{-3}$

Soil depth, cm

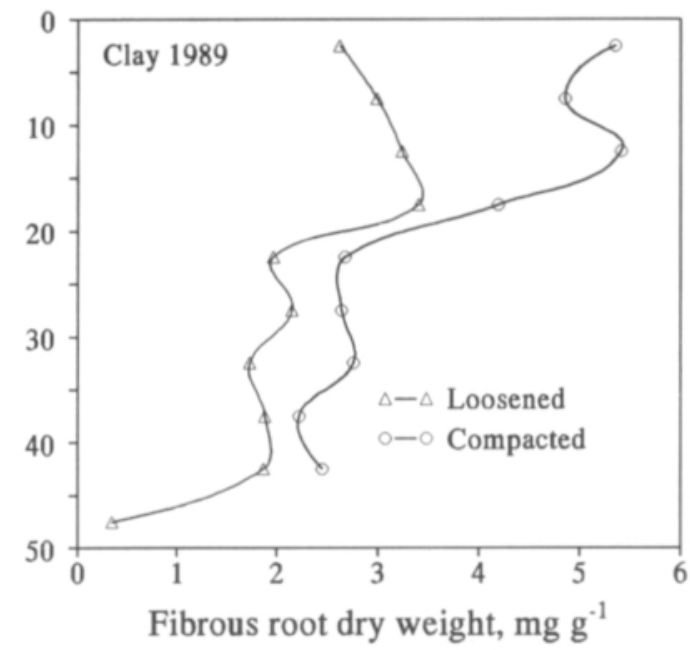

